\title{
ipen
}

INSTITUTO DE PESQUISAS ENERGÉTICAS E NUCLEARES Autarquia Associada à Universidade de São Paulo

\section{SÍNTESE POR REAÇÃO DO TIFe NANOESTRUTURADO PARA O ARMAZENAMENTO DE HIDROGÊNIO, A PARTIR DA MOAGEM DE ALTA ENERGIA DE MISTURAS DE PÓS DE $\mathrm{TiH}_{2} \mathrm{E} \mathrm{Fe}$}

\section{RAILSON BOLSONI FALCÃO}

Tese apresentada como parte dos requisitos para obtenção do Grau de Doutor em Ciências na Área de Tecnologia Nuclear - Materiais

Orientador:

Prof. Dr. Ricardo Mendes Leal Neto

São Paulo

2016 
Aos meus pais, José e Cristina, e ao meu irmão, Ronald, com carinho 


\section{AGRADECIMENTOS}

Em especial, ao meu orientador Dr. Ricardo Mendes Leal Neto, coordenador do Laboratório de Materiais Intermetálicos (LMI - CCTM/IPEN), pela confiança depositada em mim e, sobretudo, pelo incentivo constante e participação decisiva em todos os estágios deste trabalho. Também a todos os integrantes do LMI, em especial ao Dr. Cláudio José da Rocha, pelo apoio em diversos estágios deste trabalho.

Ao Dr. Hidetoshi Takiishi, coordenador do Laboratório de Materiais Magnéticos (LMM - CCTM/IPEN), pelo apoio e contribuições na redação final deste trabalho.

Ao Dr. Luis Gallego Martinez, coordenador do Laboratório de Cristalografia (LC CCTM/IPEN), pelo apoio e contribuições na redação final deste trabalho. Também a todos os integrantes do LC, em especial ao Dr. Rodrigo Uchida Ichikawa, pelo apoio na realização das análises por DRX.

Ao Dr. Michelangelo Durazzo (CCN/IPEN), pelo apoio na realização das análises por DSC e TG.

Aos integrantes do Laboratório de Fluorescência de Raios X (LFRX - CQMA/IPEN), em especial ao Dr. Marcos Antônio Scapin, pelo apoio na realização das análises por EDXRF.

Aos integrantes do Laboratório de Análises Química e Ambiental (LAQA CQMA/IPEN), em especial ao MSc. Sérgio Carvalho Moura, pelo apoio na realização das análises por absorção IV.

Aos integrantes do Laboratório de Microscopia e Microanálises (LMM - CCTM/IPEN), em especial ao Dr. Glauson Aparecido Ferreira Machado e ao MSc. Celso Vieira de Morais, pelo apoio na realização das análises por MEV.

Ao Dr. Ricardo Floriano (FCA/UNICAMP), pelas contribuições na redação final deste trabalho.

Ao Dr. Walter José Botta Filho, coordenador do Laboratório de Caracterização Estrutural (LCE - DEMa/UFSCar), pelas contribuições na redação final deste trabalho. Também a todos os integrantes do LCE, pelo apoio na realização das análises por MET.

À Fundação de Amparo à Pesquisa do Estado de São Paulo (FAPESP), pelo suporte financeiro de projeto (processo $n^{\circ}$ 2001/03961-4 e processo $n^{\circ}$ 2007/50018-2). Também ao Conselho Nacional de Desenvolvimento Cientifico e Tecnológico (CNPq), pelo suporte financeiro de projeto (processo $\mathrm{n}^{\mathrm{o}}$ 481079/2008-2) e concessão de bolsa de doutorado. Em especial, ao Instituto de Pesquisas Energéticas e Nucleares (IPEN - CNEN/SP), pelos suportes técnico e financeiro, fundamentais em todos os estágios deste trabalho.

A todos os meus amigos, sem os quais a conclusão deste trabalho teria sido uma tarefa impossível. 


\title{
SÍNTESE POR REAÇÃO DO TIFe NANOESTRUTURADO PARA O ARMAZENAMENTO DE HIDROGÊNIO, A PARTIR DA MOAGEM DE ALTA ENERGIA DE MISTURAS DE PÓS DE $\mathrm{TiH}_{2}$ E Fe
}

\author{
Railson Bolsoni Falcão
}

\section{RESUMO}

Neste trabalho investigou-se a obtenção do composto TiFe a partir da moagem de alta energia de misturas de pós de $\mathrm{TiH}_{2}$ e $\mathrm{Fe}$, seguida de aquecimento sob vácuo para a reação de síntese. No lugar do $\mathrm{Ti}, \circ \mathrm{TiH}_{2}$ foi escolhido como precursor em razão de sua fragilidade, benéfica para a diminuição da aderência dos pós ao ferramental de moagem. Foram preparados dois lotes de misturas obedecendo-se a relação Ti:Fe de 50:50 e 56:44. Ambos foram processados em um moinho do tipo planetário por tempos que variaram de 5 até 40 horas, sob atmosfera de argônio de elevada pureza. Em todos os experimentos foram mantidos constantes a velocidade de rotação do prato do moinho, a quantidade de amostra, o diâmetro e o número de bolas. As amostras moídas foram caracterizadas por calorimetria exploratória diferencial (DSC), termogravimetria (TG), microscopia eletrônica de varredura (MEV), difração de raios $X(D R X)$ e fluorescência de raios $X$ por dispersão de energia (EDXRF). Apenas $\mathrm{TiH}_{2}$ e Fe foram observados nas amostras moídas, com um grau crescente de mistura em função do tempo de moagem. $O$ composto TiFe nanoestruturado $(12,5$ a 21,4nm) foi obtido de forma majoritária em todas as amostras após a reação de síntese promovida pelo tratamento térmico a $600^{\circ} \mathrm{C}$ (873K). As amostras reagidas foram caracterizadas por microscopia eletrônica de transmissão (MET) e DRX. Um equipamento do tipo Sievert, operando sob um fluxo constante (modo dinâmico), foi utilizado para levantar as curvas termodinâmicas de absorção e dessorção de hidrogênio. Todas as amostras absorveram hidrogênio à temperatura ambiente ( 298K) 
sem a necessidade de ciclos térmicos de ativação. Os melhores resultados foram obtidos com as amostras moídas por 25 e 40 horas, de composição não estequiométrica 56:44. Tais amostras absorveram e dessorveram hidrogênio à temperatura ambiente, sob os platôs de aproximadamente 6,4 e 2,2bar $(\sim 0,6 \mathrm{e}$ $0,2 \mathrm{MPa}$ ), respectivamente. A capacidade máxima de armazenamento foi de $1,06 \%$ em massa de hidrogênio ( $\mathrm{H}: \mathrm{M} 0,546)$, sob pressão de até 11 bar $(1,1 \mathrm{MPa})$, com reversão de até $1,085 \%$ em massa de hidrogênio ( $\mathrm{H}: \mathrm{M} \sim 0,559)$, sob pressão de até 1 bar $(0,1 \mathrm{MPa})$. Estas amostras também apresentaram maior cinética de absorção e dessorção de hidrogênio com fluxos de 1,23 (25h) e $2,86 \mathrm{~cm}^{3} / g$.min. (40h). Tais resultados são atribuídos à variação composicional da fase $\mathrm{TiFe}$ e à maior quantidade de $\mathrm{TiH}_{2}$ livre. 


\title{
REACTION SYNTHESIS OF NANOSTRUCTURED TIFe FOR HYDROGEN STORAGE FROM HIGH-ENERGY BALL MILLING OF $\mathrm{TiH}_{2}$ AND Fe POWDERS MIXTURES
}

\author{
Railson Bolsoni Falcão
}

\begin{abstract}
In this work high-energy ball milling from $\mathrm{TiH}_{2}$ and Fe powder mixtures, followed by post-heating under vacuum, were performed for the reaction synthesis of TiFe compound. $\mathrm{TiH}_{2}$ was used instead of $\mathrm{Ti}$ due to its brittleness, preventing strong particles adhesion to the grinding balls and vial walls. Two mixtures batches were prepared following Ti:Fe ratios of 50:50 and 56:44. Both of them were dry-milled in a planetary mill for times ranging from 5 to 40 hours, under high purity argon atmosphere. The speed of main disk rotation, the amount of sample, number and diameter of the balls were kept constant in all experiments. As-milled samples were characterized by differential scanning calorimetry (DSC), thermogravimetric analysis (TG), scanning electron microscopy (SEM), X-ray diffraction (XRD) and energy dispersive X-ray fluorescence (EDXRF). As-milled materials presented only $\mathrm{Fe}$ and $\mathrm{TiH}_{2}$ phases showing increased mixture degree with the milling time. After heat treatment at $600^{\circ} \mathrm{C}(873 \mathrm{~K})$, nanostructured TiFe compound (12.5 to $\left.21.4 \mathrm{~nm}\right)$ was mostly formed in all samples. Reacted samples were characterized by transmission electron microscopy (TEM) and XRD. Hydrogen absorption and desorption thermodynamics curves were determined in a Sievert-type apparatus operating at constant flow (dynamic mode). All samples absorbed hydrogen at room temperature $(\sim 298 \mathrm{~K})$ requiring no thermal activation cycles. Best results were seen on samples milled at 25 and 40 hours, with non-stoichiometric composition $56: 44$. Those samples absorbed and desorbed hydrogen at plateaus of 6.4 and 2.2bar ( 0.6 and 0.2MPa), respectively. Maximum hydrogen storage capacity
\end{abstract}


was 1.06 wt\% (H:M 0,546) at $11 \mathrm{bar}(1.1 \mathrm{MPa})$, with reversion of $1.085 \mathrm{wt} \%$ $(\mathrm{H}: \mathrm{M} 0,559)$ at 1 bar $(0.1 \mathrm{MPa})$. Higher hydrogen absorption and desorption kinetics were observed in those samples, as well, with flows of $1.23(25 \mathrm{~h})$ and $2.86 \mathrm{~cm}^{3} / \mathrm{g}$. min. (40h). Such results were assigned to the compositional variation of TiFe phase and to the largest amount of free $\mathrm{TiH}_{2}$. 


\section{LISTA DE ILUSTRAÇÕES}

FIGURA 1 - Volume ocupado por 4Kg de hidrogênio compactado de diversas formas

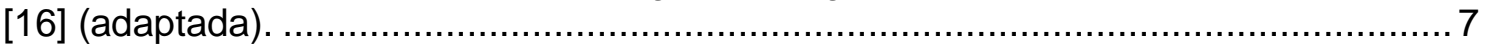

FIGURA 2 - Curva de potencial de Lennard-Jones para a ligação M-H (adaptada) [17].

FIGURA 3 - Processo de formação do hidreto de metal (adaptada) [16].

FIGURA 4 - Densidade de energia volumétrica e gravimétrica para diversas formas de armazenamento de hidrogênio [29] (adaptada).

FIGURA 5 - llustrações de algumas das atuais aplicações dos hidretos de metais: (a) Dispositivos armazenadores de energia elétrica (pilhas de Ni-MH); (b) Tanques armazenadores de hidrogênio.

FIGURA 6 - Diagrama de equilíbrio estável de fases do sistema Ti-Fe [43].

FIGURA 7 - Células unitárias de estruturas cristalinas de materiais citados no texto: (a) TiFe (ICSD 633950); (b) $\mathrm{TiFe}_{2}$ (ICSD 657043); (c) TiFeH (ICSD 602022); (d) $\mathrm{TiFeH}_{2}$ (ICSD 601978)

FIGURA 8 - Principais estágios envolvidos no processo de moagem de alta energia $[48,53,55]$ (adaptada).

FIGURA 9 - Termograma (DTA) do material moído por 36 horas [7] 21

FIGURA 10 - (a) Difratogramas de raios $X(D R X)$ dos materiais moídos por diferentes tempos; (b) Curvas PCTs (Pressão-Composição e Temperatura) a temperatura constante de $303 \mathrm{~K}$ para o TiFe elaborado mecanicamente após 10 e 40 horas de moagem; (c) Rendimentos do processo após diferentes tempos de moagem [3]........24

FIGURA 11 - (a) Difratogramas de raios $X$ (DRX) dos materiais moídos por diferentes tempos; (b) Curvas PCTs a temperatura constante de $298 \mathrm{~K}$ para o TiFe elaborado mecanicamente após 20 horas de moagem; (c) Micrografia de elétrons transmitidos (MET) do TiFe elaborado mecanicamente após 20 horas de moagem, além do detalhe do padrão de difração de elétrons da fase TiFe [2] (adaptada). 26

FIGURA 12 - (a) Variação do parâmetro de rede para as diferentes condições de moagem; (b) Termogramas (DSC) dos materiais moídos por 120 minutos com baixa rotação (620rpm) e alta rotação (840rpm) [5] (adaptada). 29

FIGURA 13 - (a) Curvas de absorção de hidrogênio a temperatura constante de 283K e pressão de $2 \mathrm{MPa}$ para o TiFe moído por diferentes tempos em atmosfera de argônio; (b) Curvas de absorção de hidrogênio a temperatura constante de $283 \mathrm{~K}$ e pressão de 2MPa para o TiFe moído por 30 minutos em atmosfera de argônio, e após a exposição a atmosfera não controlada [67].

FIGURA 14 - (a) Difratogramas de raios $X(D R X)$ do material moído e tratado termicamente a diferentes temperaturas; (b) Curvas PCTs a temperatura constante de 303K para o TiFe sintetizado após os tratamentos térmicos a diferentes temperaturas [3]. 33

FIGURA 15 - Exemplo de aderência dos pós de Ti e Fe ao recipiente de moagem [9].

FIGURA 16 - Ilustração esquemática do recipiente utilizado nas moagens: (a) Visão explodida do recipiente; (b) Dimensões do recipiente (em $\mathrm{mm}$ ).

FIGURA 17 - llustração dos equipamentos utilizados nas moagens dos pós: (a) Caixa de luvas com argônio purificado; (b) Moinho do tipo planetário. 
FIGURA 18 - Fluxograma dos procedimentos utilizados na preparação e

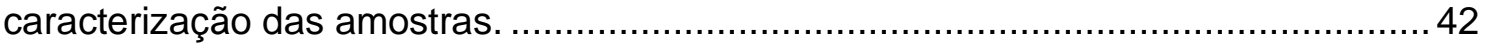

FIGURA 19 - Ilustração do equipamento do tipo Sievert construído pelo LMI (CCTM/IPEN): (a) Painel de controle central do equipamento; (b) Forno resistivo tubular conectado ao reator; (c) Reator conectado a uma bomba auxiliar turbomolecular.

FIGURA 20 - Curva típica da histerese de pressão-composição a temperatura constante [45].

FIGURA 21 - lustração da retorta de aço utilizada nos tratamentos térmicos e no estudo das propriedades de armazenamento de hidrogênio do TiFe. 48

FIGURA 22 - Ilustração esquemática simplificada do equipamento do tipo Sievert construído pelo LMI (CCTM/IPEN) e utilizado no estudo das propriedades de armazenamento de hidrogênio do TiFe.

FIGURA 23 - Termogramas (DSC e TG) do pó de $\mathrm{TiH}_{2}$ utilizado como um dos materiais de partida nas moagens.

FIGURA 24 - Difratogramas de raios X (DRX) dos pós de partida $\left(\mathrm{TiH}_{2}\right.$ e Fe) utilizados nas moagens das amostras: (a) Visão geral das fases presentes; (b) Visão expandida na região do pico (110) da fase Fe. 52

FIGURA 25 - Curvas da estimativa da porcentagem atômica de Ti em solução no Fe após as moagens por diferentes tempos das composições 50:50 e 56:44. 54

FIGURA 26 - Difratogramas de raios $X(D R X)$ das amostras moídas por diferentes tempos da composição 50:50: Visão geral das fases presentes; (b) Visão expandida na região do pico (110) da fase Fe.

FIGURA 27 - Difratogramas de raios X (DRX) das amostras moídas por diferentes tempos da composição 56:44: Visão geral das fases presentes; (b) Visão expandida na região do pico (110) da fase Fe.

FIGURA 28 - Micrografias de varredura de elétrons retroespalhados (MEV-FEG) da microestrutura dos agregados soltos após a moagem por diferentes tempos da composição 50:50.

FIGURA 29 - Micrografias de varredura de elétrons retroespalhados (MEV-FEG) da microestrutura dos agregados soltos após a moagem por diferentes tempos da composição 56:44.

FIGURA 30 - Micrografias de varredura de elétrons secundários (MEV) da forma dos agregados soltos após as moagens por diferentes tempos da composição 50:50.....64

FIGURA 31 - Micrografias de varredura de elétrons secundários (MEV) da forma dos agregados soltos após as moagens por deferentes tempos da composição 56:44....66

FIGURA 32 - Termogramas (DSC e TG) das amostras moídas por diferentes tempos da composição 50:50: (a) DSC; (b) TG.

FIGURA 33 - Difratogramas de raios X (DRX) das amostras moídas por diferentes tempos e reagidas a $600^{\circ} \mathrm{C}$ da composição 50:50: Visão geral das fases presentes; (b) Visão expandida na região do pico (110) da fase TiFe.

FIGURA 34 - Difratogramas de raios X (DRX) das amostras moídas por diferentes tempos e reagidas a $600^{\circ} \mathrm{C}$ da composição $56: 44$ : Visão geral das fases presentes; (b) Visão expandida na região do pico (110) da fase TiFe.

FIGURA 35 - Difratogramas de raios X (DRX) das amostras moídas por diferentes tempos e reagidas a 800ํㅡ da composição 50:50: (a) Visão geral das fases presentes; (b) Visão expandida na região do pico (110) da fase TiFe. 
FIGURA 36 - Diagrama de fases do sistema Ti-O-Fe [82].

FIGURA 37 - (a) Parâmetros de rede, além do detalhe das porcentagens atômicas de Ti e Fe; (b) tamanho médio de cristalito $\left(<L>>_{v}\right)$ e microdeformação $(\varepsilon)$ da fase TiFe das amostras moídas por diferentes tempos e reagidas a 600 e $800^{\circ} \mathrm{C}$ das composições $50: 50$ e $56: 44$

FIGURA 38 - Micrografias de elétrons transmitidos (MET) das amostras moídas por 10 e 40 horas e reagidas a $600^{\circ} \mathrm{C}$ da composição $50: 50$, além do detalhe do padrão de difração de elétrons da fase TiFe.

78

FIGURA 39 - Difratogramas de raios X (DRX) das amostras moídas por diferentes tempos e reagidas a $600^{\circ} \mathrm{C}$ da composição 50:50 após o clico de hidretação: (a) Visão geral das fases presentes; (b) Visão expandida na região do pico (110) da fase TiFe.

FIGURA 40 - Difratogramas de raios X (DRX) das amostras moídas por diferentes tempos e reagidas a $600^{\circ} \mathrm{C}$ da composição 56:44 após o clico de hidretação: (a) Visão geral das fases presentes; (b) Visão expandida na região do pico (110) da fase TiFe.

FIGURA 41 - (a) Parâmetros de rede; (b) tamanho médio de cristalito $(<L>v)$ e microdeformação $(\varepsilon)$ da fase TiFe das amostras moídas por diferentes tempos e reagidas a $600^{\circ} \mathrm{C}$ das composições 50:50 e 56:44 após o ciclo de hidretação.

FIGURA 42 - Diferença de pressão do equipamento ao longo do resfriamento das amostras moídas e reagidas a $600^{\circ} \mathrm{C}$ das composições: (a) $50: 50$; (b) $56: 44 \ldots \ldots \ldots \ldots . . .85$

FIGURA 43 - Diferença de pressão do equipamento em função do tempo para a dessorção e absorção de hidrogênio das amostras moídas por diferentes tempos e reagidas a $600^{\circ} \mathrm{C}$ da composição 50:50.

FIGURA 44 - Diferença de pressão do equipamento em função do tempo para a dessorção e absorção de hidrogênio das amostras moídas por diferentes tempos e reagidas a $600^{\circ} \mathrm{C}$ da composição 56:44.

FIGURA 45 - Curvas PCTs à temperatura ambiente para as amostras moídas por diferentes tempos e reagidas a $600^{\circ} \mathrm{C}$ das composições: (a) 50:50; (b) $56: 44 \ldots \ldots \ldots . . .96$

FIGURA 46 - Comparação das curvas PCTs dos melhores resultados obtidos no presente trabalho com os obtidos da literatura: (a) Abe et al. (2007); (b) Hotta et al. (2007).

FIGURA 47 - Fluxos de dessorção e absorção de hidrogênio das amostras moídas por diferentes tempos e reagidas a $600^{\circ} \mathrm{C}$ das composições: (a) 50:50; (b) $56: 44 \ldots \ldots \ldots . . . .99$

FIGURA 48 - Diagrama esquemático de um moinho do tipo planetário [85]............. 110

FIGURA 49 - Curvas típicas de pressão em função do tempo para os experimentos em branco e com amostra. 112

FIGURA 50 - Curva típica da diferença de pressão do equipamento em função do

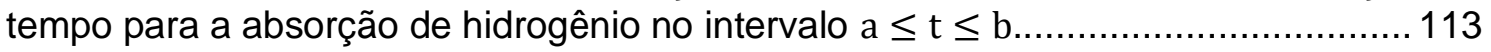

FIGURA 51 - Curva da pressão em função do número de mols de hidrogênio introduzidos no volume de trabalho do equipamento Sievert. .................................. 114

FIGURA 52 - Diferença de pressão do equipamento em função do tempo para a absorção de hidrogênio das amostras de Ti puro: (a) Ti-01; (b) Ti-02 .......................117

FIGURA 53 - Ajuste dos padrões de difração de raios $X(D R X)$ das amostras moídas por 5 e 10 horas e reagidas a $600^{\circ} \mathrm{C}$ da composição $50: 50$. 119 
FIGURA 54 - Ajuste dos padrões de difração de raios $X(D R X)$ das amostras moídas por 25 e 40 horas e reagidas a $600^{\circ} \mathrm{C}$ da composição 50:50.

FIGURA 55 - Ajuste dos padrões de difração de raios $X(D R X)$ das amostras moídas por 5 e 10 horas e reagidas a 600ำ da composição 56:44.

FIGURA 56 - Ajuste dos padrões de difração de raios $X(D R X)$ das amostras moídas por 25 e 40 horas e reagidas a $600^{\circ} \mathrm{C}$ da composição 56:44.

FIGURA 57 - Ajuste dos padrões de difração de raios X (DRX) das amostras moídas por 5 e 10 horas e reagidas a $800^{\circ} \mathrm{C}$ da composição 50:50. 123

FIGURA 58 - Ajuste dos padrões de difração de raios $X$ (DRX) das amostras moídas por 25 e 40 horas e reagidas a $800^{\circ} \mathrm{C}$ da composição $50: 50$. 124

FIGURA 59 - Ajuste dos padrões de difração de raios $X(D R X)$ das amostras moídas por 5 e 10 horas e reagidas a 600ํ da composição 50:50 após o ciclo de hidretação. 125

FIGURA 60 - Ajuste dos padrões de difração de raios $X(D R X)$ das amostras moídas por 25 e 40 horas e reagidas a 600ํㅡ da composição 50:50 após o ciclo de hidretação. 126

FIGURA 61 - Ajuste dos padrões de difração de raios $X(D R X)$ das amostras moídas por 5 e 10 horas e reagidas a 600ํํ da composição 56:44 após o ciclo de hidretação.

FIGURA 62 - Ajuste dos padrões de difração de raios X (DRX) das amostras moídas por 25 e 40 horas e reagidas a 600ํㅡ da composição 56:44 após o ciclo de hidretação. 


\section{LISTA DE TABELAS}

TABELA 1 - Propriedades de armazenamento de hidrogênio em diversos tipos de compostos intermetálicos [42]....

TABELA 2 - Variáveis do processo de moagem do composto TiFe em referências

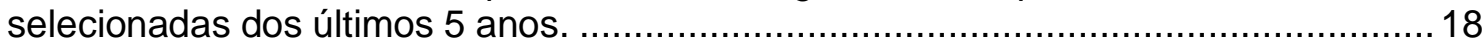

TABELA 3 - Contaminantes presentes nos materiais de partida. ................................52

TABELA 4 - Rendimentos (\% em massa) e energia total fornecida pelo sistema ao pó moído $\left(E_{t}\right)$ após as moagens por diferentes tempos das amostras das composições 50:50 e 56:44.

TABELA 5 - Estimativas da porcentagem atômica de Ti em solução no Fe após as moagens por diferentes tempos das composições 50:50 e 56:44.

TABELA 6 - Contaminantes presentes nas amostras moídas por diferentes tempos da composição 50:50.

TABELA 7 - Microanálises por EDS das amostras moídas por diferentes tempos das composições 50:50 e 56:44.

TABELA 8 - Parâmetros microestruturais e composição de fases (\% em massa) das amostras moídas por diferentes tempos e reagidas a 600 e $800^{\circ} \mathrm{C}$ das composições 50:50 e 56:44.

TABELA 9 - Parâmetros microestruturais e composição de fases (\% em massa) das amostras moídas por diferentes tempos e reagidas a 600드 das composições 50:50 e 56:44 após o ciclo de hidretação.

TABELA 10 - Propriedades de dessorção de hidrogênio das amostras moídas por diferentes tempos e reagidas a $600^{\circ} \mathrm{C}$ da composição 50:50.

TABELA 11 - Propriedades de absorção de hidrogênio das amostras moídas por diferentes tempos e reagidas a $600^{\circ} \mathrm{C}$ da composição $50: 50$.

TABELA 12 - Propriedades de dessorção de hidrogênio das amostras moídas por diferentes tempos e reagidas a $600^{\circ} \mathrm{C}$ da composição 56:44.

TABELA 13 - Propriedades de absorção de hidrogênio das amostras moídas por diferentes tempos e reagidas a $600^{\circ} \mathrm{C}$ da composição $56: 44$

TABELA 14 - Estimativas de hidrogênio residual no composto TiFe após o ciclo de hidretação das amostras moídas por diferentes tempos e reagidas a $600^{\circ} \mathrm{C}$ das composições 50:50 e 56:44.

TABELA 15 - Propriedades de absorção de hidrogênio das amostras de Ti puro. ... 116 


\section{SUMÁRIO}

1 INTRODUÇÃO

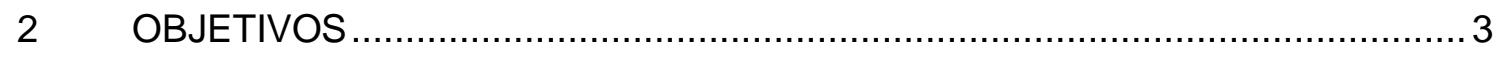

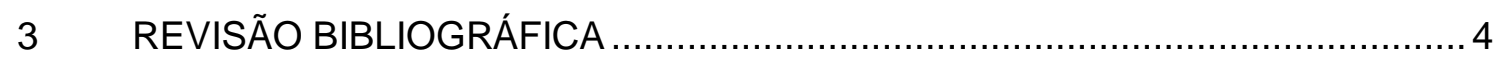

3.1 A economia do hidrogênio: Uma nova era na geração de energias limpas ..... 4

3.2 Formas de armazenamento de hidrogênio................................................ 6

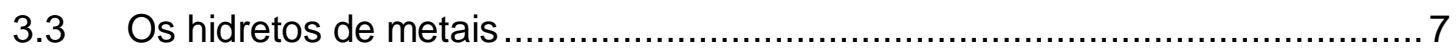

3.3.1 Processo de formação dos hidretos de metais ......................................

3.3.2 Aplicações dos hidretos de metais......................................................

3.3.3 Armazenamento de hidrogênio no composto intermetálico TiFe............ 12

3.4 Moagem de alta energia de compostos intermetálicos................................. 14

3.4.1 Variáveis do processo de moagem de alta energia................................ 16

3.5 Obtenção do composto TiFe por moagem de alta energia e suas propriedades no armazenamento de hidrogênio ......................................................17

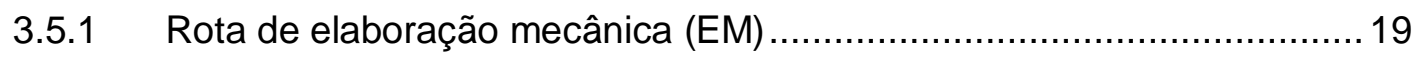

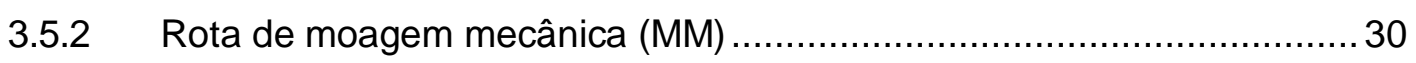

3.5.3 Controle da aderência e atividade do composto TiFe após a moagem .. 36

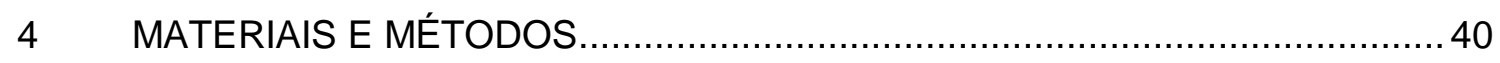

4.1 Moagem dos pós de partida $\left(\mathrm{TiH}_{2}\right.$ e Fe) ……....................................... 40

4.1.1 Caracterização dos pós de partida e moídos ....................................... 42

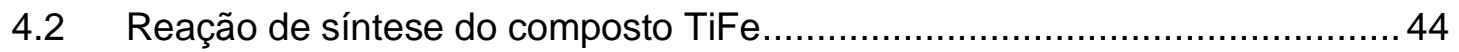

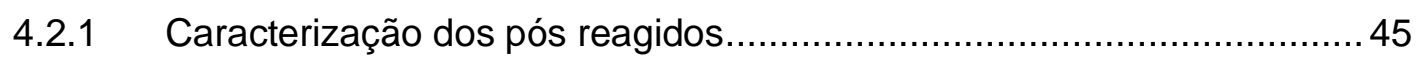

4.3 Estudo das propriedades de armazenamento de hidrogênio do TiFe ............46

4.3.1 Caracterização dos pós reagidos após o ciclo de hidretação.................. 49

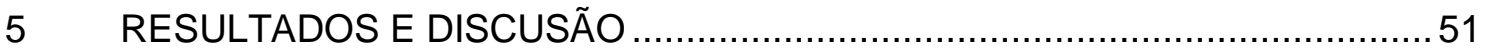

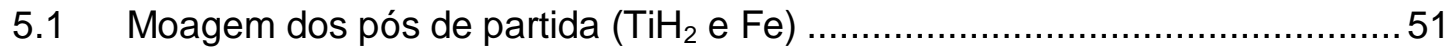

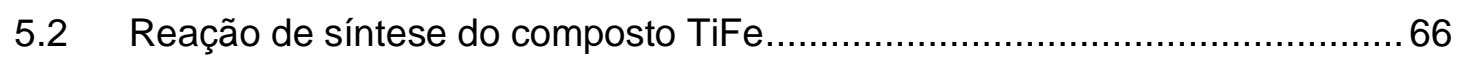

5.3 Estudo das propriedades de armazenamento de hidrogênio do TiFe ............78

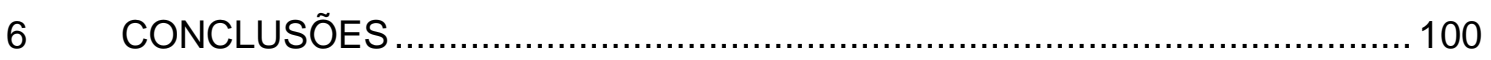

7 SUGESTÕES PARA TRABALHOS FUTUROS .............................................. 102

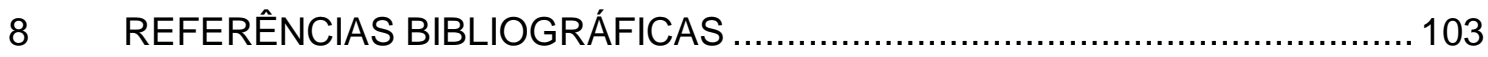

9 APÊNDICE A - Modelo simplificado de transferência de energia para moinhos

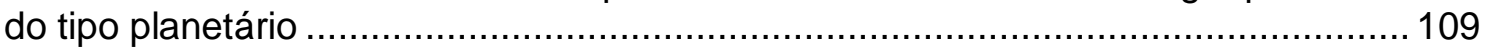

10 APÊNDICE B - Metodologia empregada na análise dos dados fornecidos pelo

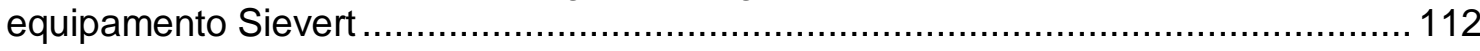

11 APÊNDICE C - Refinamentos pelo método de Rietveld...................................118 


\section{INTRODUÇÃO}

Nas últimas décadas, a crescente demanda pela geração de energia limpa tem impulsionado o desenvolvimento das tecnologias relacionadas à chamada economia do hidrogênio. Uma destas vertentes tecnológicas se refere especificamente ao armazenamento de hidrogênio em compostos intermetálicos. O Laboratório de Materiais Intermetálicos (LMI), integrante do Centro de Ciência e Tecnologia de Materiais (CCTM) do Instituto de Pesquisas Energéticas e Nucleares (IPEN-CNEN/SP), com mais de 15 anos de experiência na síntese de compostos intermetálicos por moagem de alta energia, vislumbrou então a possibilidade de contribuir positivamente com 0 desenvolvimento desta tecnologia no país.

Para se introduzir nesta área, o grupo envolvido no presente trabalho decidiu-se pelo processamento do TiFe, um conhecido composto intermetálico armazenador de hidrogênio, utilizado para este fim desde a década de 60 [1]. 0 TiFe se destaca dentre os demais compostos armazenadores devido à alta capacidade de armazenagem de hidrogênio à temperatura ambiente (até $1,89 \%$ em massa de $\mathrm{H}_{2}$ ), além da grande abundância e custo relativamente baixo dos seus elementos formadores [2]. Em razão da experiência prévia, foi natural a síntese do TiFe a partir da moagem de alta energia dos pós de Ti e $\mathrm{Fe}$, a exemplo de tantos outros trabalhos da literatura [2-8].

Durante os primeiros experimentos, um dos principais desafios enfrentados pelo grupo foi como aumentar o rendimento do processo de moagem e ao mesmo tempo obter o TiFe de forma majoritária, já apto para absorver hidrogênio pela primeira vez à temperatura ambiente, sem a necessidade de posteriores ciclos de ativação térmica (TiFe ativo). Realmente, os primeiros resultados obtidos após as moagens mostraram uma forte tendência das partículas dos pós de Ti e Fe à aderência ao ferramental de moagem, o que ocasionava uma grande perda no rendimento do processo [9]. Além disso, as pequenas quantidades do material assim obtido apresentavam muitas vezes segundas fases, bem como uma dificuldade inicial para absorver hidrogênio pela primeira vez à temperatura ambiente, resultado associado a um aumento da reatividade dos pós moídos com oxigênio. 
As primeiras tentativas de solucionar o problema inicial da aderência consistiram em adicionar diferentes Agentes Controladores de Processo (ACPs), como o etanol, o ácido esteárico, o polietileno de baixa densidade, o benzeno e o ciclohexano, em quantidades variadas (entre 1 e $20 \%$ em massa da mistura de pós de Ti e Fe). Contudo, apesar de prevenir a aderência, verificou-se que quanto maior a quantidade de ACP adicionada a mistura de pós de Ti e Fe, em particular de benzeno e ciclohexano, maior o tempo de moagem necessário para a formação da fase desejada ( $\mathrm{TiFe}$ ), ainda assim apenas de forma parcial, já que a fase TiC também era formada como resultado da decomposição dos ACPs durante os prolongados tempos de moagem empregados [9].

As investigações se seguiram então sem a adição de qualquer tipo de ACP nas moagens, onde diferentes estratégias foram empregadas na tentativa de prevenir a aderência [10]. Os melhores resultados, em termos de massa de pó solto, foram observados quando se utilizaram como pós de partida o $\mathrm{TiH}_{2}$ e $\mathrm{Fe}$ (um rendimento de até $93 \%$ em massa), embora a formação parcial da fase TiFe tenha sido obtida somente após a aplicação de tratamentos térmicos [10,11]. Tal resultado encorajou o grupo a realizar a presente investigação sobre a moagem de alta energia de misturas dos pós de $\mathrm{TiH}_{2}$ e Fe para síntese do TiFe, bem como sobre as possíveis melhorias nas propriedades de armazenagem de hidrogênio do composto por meio da moagem de misturas mais ricas em $\mathrm{TiH}_{2}$. Os experimentos com hidrogênio foram conduzidos em um equipamento do tipo Sievert, de construção própria do LMI, e os resultados obtidos foram comparados com a literatura pertinente. 


\section{OBJETIVOS}

O objetivo principal deste trabalho foi investigar uma rota de processamento, a partir da moagem de alta energia dos pós de $\mathrm{TiH}_{2}$ e $\mathrm{Fe}$, que fosse capaz de sintetizar com sucesso o composto intermetálico TiFe, tendo em vista:

- O controle da aderência dos pós de partida $\left(\mathrm{TiH}_{2}\right.$ e $\left.\mathrm{Fe}\right)$ ao ferramental de moagem, aumentando assim o rendimento do processo;

- A obtenção do TiFe de forma majoritária no processo, já apto para absorver hidrogênio pela primeira vez à temperatura ambiente, sem a necessidade de posteriores ciclos de ativação térmica.

Este amplo objetivo englobou ainda a investigação sobre as possíveis melhorias nas propriedades de armazenamento de hidrogênio do composto TiFe por meio da adição de maiores quantidades de $\mathrm{TiH}_{2}$ à mistura inicial dos pós de partida, visando:

- Uma melhoria na cinética de absorção e dessorção de hidrogênio pelo composto sintetizado;

- A redução dos platôs de pressão na absorção e dessorção de hidrogênio pelo composto sintetizado. 


\section{REVISÃO BIBLIOGRÁFICA}

\subsection{A economia do hidrogênio: Uma nova era na geração de energias limpas}

É inegável o fato de que atualmente os combustíveis de origem fóssil são os vetores energéticos que impulsionam as principais economias mundiais. No Brasil, por exemplo, estes são responsáveis por cerca de $54,7 \%$ da oferta interna de energia, sendo a parte majoritária deste valor consumida na geração de energia para o setor de transportes [12]. Porém, nas últimas décadas, o seu consumo indiscriminado tem sido amplamente questionado pela comunidade cientifica, principalmente pela crescente emissão antrópica do gás carbônico $\left(\mathrm{CO}_{2}\right)$, associado frequentemente ao desequilíbrio climático do nosso planeta [13, 14]. Outro ponto que também tem sido alvo de questionamentos é o aumento da emissão de gases poluentes como o monóxido de carbono (CO), o dióxido de enxofre $\left(\mathrm{SO}_{2}\right)$ e o dióxido de nitrogênio $\left(\mathrm{NO}_{2}\right)$, além de material particulado (MP), considerados nocivos não só ao meio ambiente, mas também à saúde humana. Em grandes centros urbanos, por exemplo, o aumento da concentração destes poluentes na atmosfera tem sido associado diretamente a um agravamento de doenças respiratórias, cardiovasculares e neurológicas, especialmente em crianças e idosos. Já em áreas rurais, estes têm provocado sérios danos ao meio ambiente, reduzindo a produtividade agrícola e contaminando os recursos hídricos [15].

Diante deste cenário, existe um consenso de que um novo modelo econômico baseado em vetores energéticos que sejam capazes de manter o equilíbrio natural do nosso planeta deverá ser colocado em prática rapidamente. Atualmente a chamada economia do hidrogênio se mostra como uma das principais candidatas na tentativa de suprir tal demanda na geração de energias limpas [13,16-20]. Contudo, apesar dos benefícios ambientais e à saúde humana que poderiam advir desta nova economia, sua implementação tem sido postergada há décadas, pois os primeiros relatos de um modelo econômico baseado no hidrogênio em substituição ao atual, baseado quase que exclusivamente nos combustíveis fósseis, são datados da década de 60 [21]. 
A demora na transição destes modelos econômicos, de pelo menos meio século, é um assunto deveras extenso e complexo, que envolve não só obstáculos tecnológicos, mas também políticos e econômicos. Porém, se observarmos o assunto de um ponto de vista exclusivamente tecnológico, não é difícil encontrar uma série de mitos que podem ter contribuído decisivamente neste sentido. Um bom exemplo disso é o mito relacionado à segurança do uso do hidrogênio como combustível, que em tese seria inferior a dos demais tipos de combustíveis. Todavia, qualquer tipo de combustível pode oferecer riscos ao ser manipulado, sendo que os associados à manipulação do hidrogênio podem ser mais facilmente controlados se comparados com outros tipos de combustíveis, como o vapor de gasolina ou o gás natural. De fato, maior difusibilidade e leveza permitem que o hidrogênio se disperse mais rapidamente no caso de vazamentos. Além disso, quando queimado ao ar, o hidrogênio emite pouco calor radiante e não libera fumaça, fatores estes responsáveis por um grande número de vitimas em casos de acidentes com combustíveis fósseis [22].

Outro mito a destacar é o de que se gastaria mais energia para produzir o hidrogênio do que se poderia gerar posteriormente através da sua queima, isto é, o hidrogênio apresentaria uma baixa eficiência energética quando comparado com outros tipos de combustíveis. Entretanto, a conversão de uma forma de energia para outra, independente do tipo de combustível analisado, sempre envolve um gasto energético. A gasolina, por exemplo, apresenta uma eficiência de 73 a 91\% quando obtida a partir do petróleo bruto. Já o hidrogênio pode ser obtido a partir do gás natural com uma eficiência de 72 a $85 \%$, ou através da eletrolise da água com uma eficiência de 70 a $75 \%$. Observando friamente estes números conclui-se que de fato a conversão do petróleo bruto em gasolina é mais eficiente do que a conversão do gás natural, ou mesmo da água, em hidrogênio. Entretanto, quando o hidrogênio é utilizado em células a combustível, para energizar motores elétricos, sua eficiência chega a ser três vezes maior do que a da gasolina utilizada em motores de combustão interna, o que torna o hidrogênio muito mais eficiente ao final de todo o processo [22].

Apesar de toda esta delonga relacionada ao uso do hidrogênio como combustível, os investimentos mundiais em programas de Pesquisa e Desenvolvimento (P\&D) da economia do hidrogênio só tem aumentado nas últimas décadas. De maneira geral, tais programas têm como objetivo desenvolver 
as tecnologias básicas de produção, distribuição e armazenamento de hidrogênio, tornando-as assim mais atrativas para o setor industrial. Atualmente os programas U.S. Department of Energy (DOE) Hydrogen R\&D e WE-NET, dos Estados Unidos e do Japão respectivamente, se destacam neste sentido. No Brasil, desde 2002, o programa ${ }^{1} \mathrm{ProH}_{2}$ do Ministério da Ciência e Tecnologia (MCT) tenta fundamentar as bases para o desenvolvimento destas tecnologias no país $[13,23]$. Contudo, a despeito do êxito de muitos destes programas ao redor do mundo, os programas americano e japonês já ultrapassaram os vinte anos de existência, ainda existem muitos obstáculos tecnológicos que precisam ser superados antes que a economia do hidrogênio se torne de fato uma realidade. Um destes obstáculos se refere ao ponto central do presente trabalho, que é como armazenar o hidrogênio de forma mais segura e menos custosa possíveis $[13,16,18,24]$.

${ }^{1}$ Até 2002 o programa de P\&D brasileiro era conhecido por ProCaC.

\subsection{Formas de armazenamento de hidrogênio}

Atualmente, um automóvel popular com motor de combustão interna pode percorrer até $400 \mathrm{Km}$ consumindo cerca de $24 \mathrm{Kg}$ de gasolina. A mesma distância poderia ser percorrida consumindo apenas $8 \mathrm{Kg}$ de hidrogênio no mesmo motor de combustão interna, ou apenas $4 \mathrm{Kg} \mathrm{em} \mathrm{um} \mathrm{motor} \mathrm{elétrico}$ alimentado por células a combustível. Entretanto, sob pressão atmosférica e à temperatura ambiente, $4 \mathrm{~kg}$ de hidrogênio ocupariam um volume de aproximadamente $45.000 \mathrm{~L}$, volume este muito superior ao dos atuais tanques de gasolina ( 45L), sendo assim impraticável. Surgiu então a necessidade de armazenar hidrogênio de forma mais compacta, para a qual diversas soluções já foram propostas [16, 18].

$\mathrm{Na}$ forma gasosa, o hidrogênio tem que ser armazenado em tanques sob alta pressão, entre 20 e $45 \mathrm{MPa}$, dependendo do material empregado na sua construção, podendo chegar a até $80 \mathrm{MPa}$. Ainda assim, um tanque comercial de gás ( 20MPa) com cerca $4 \mathrm{Kg}$ de hidrogênio ocuparia um volume de aproximadamente $225 \mathrm{~L}$, um volume ainda deveras elevado se comparado aos atuais tanques de combustível. Somam-se a isto os riscos à segurança subjacentes a compressões tão elevadas [16]. 
Já na forma líquida, o hidrogênio tem que ser armazenado a temperaturas criogênicas, abaixo de $21 \mathrm{~K}$ (sob pressão atmosférica). Tal opção também parece pouco viável, principalmente em virtude do alto custo dos tanques criogênicos e do dispêndio de energia para manter $O$ hidrogênio a temperaturas tão baixas. $A$ solução para estas dificuldades pode estar no armazenamento de hidrogênio em meio sólido (FIGURA 1), mais especificamente na forma de hidretos de metais [16-18].

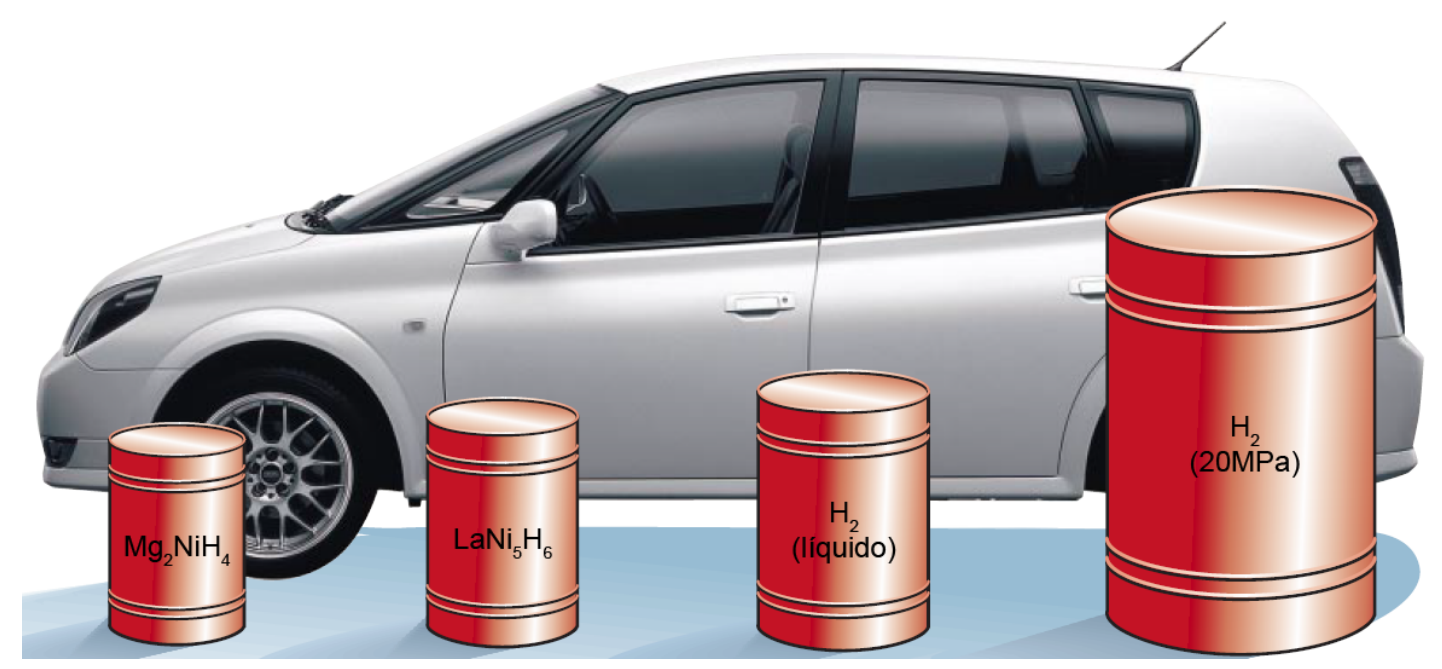

FIGURA 1 - Volume ocupado por 4Kg de hidrogênio compactado de diversas formas [16] (adaptada).

\subsection{Os hidretos de metais}

\subsubsection{Processo de formação dos hidretos de metais}

Muitos metais, ligas e compostos intermetálicos podem armazenar grandes quantidades de hidrogênio nos interstícios de suas estruturas cristalinas, formando uma liga metal-hidrogênio $(\mathrm{M}-\mathrm{H})$ concentrada, mas não necessariamente estequiométrica, chamada de hidreto de metal [16]. $O$ processo de formação dos hidretos de metais, também chamado de hidretação, consiste de diversas etapas que podem ser descritas de maneira simplificada através da curva de potencial de Lennard-Jones (FIGURA 2). Inicialmente, ao se aproximar da superfície metálica $(\sim 0,2 \mathrm{~nm})$, a molécula de hidrogênio $\left(\mathrm{H}_{2}\right)$ é fisissorvida (do inglês "physisorbed"), o mínimo da curva de potencial $\mathrm{H}_{2}+\mathrm{M}$ (FIGURA 2), atraída fracamente pela força de Van der Waals [17, 25]. Esta ligação existente entre o hidrogênio molecular e a superfície metálica é tão 
fraca que não permite, por exemplo, que quantidades significativas de hidrogênio sejam fisissorvidas à temperatura ambiente, razão pela qual o armazenamento de hidrogênio em materiais como os nanotubos de carbono só é conseguido a temperaturas criogênicas [26].

Depois de fisissorvida, se a pressão e a temperatura forem suficientemente grandes para superar a barreira de potencial, a molécula de hidrogênio se dissocia em dois átomos $\left(\mathrm{H}_{2} \rightarrow 2 \mathrm{H}\right)$ que são quimissorvidos pela superfície metálica (do inglês "chemisorbed"), o mínimo mais pronunciado da curva de potencial 2H+M (FIGURA 2). Em alguns casos, devido à formação de uma barreira de potencial dissociativa, tipicamente originada pelo "envenenamento" da superfície do material (desativação), pode ser necessária uma ativação térmica antes que este material possa quimissorver o hidrogênio $[17,27]$.

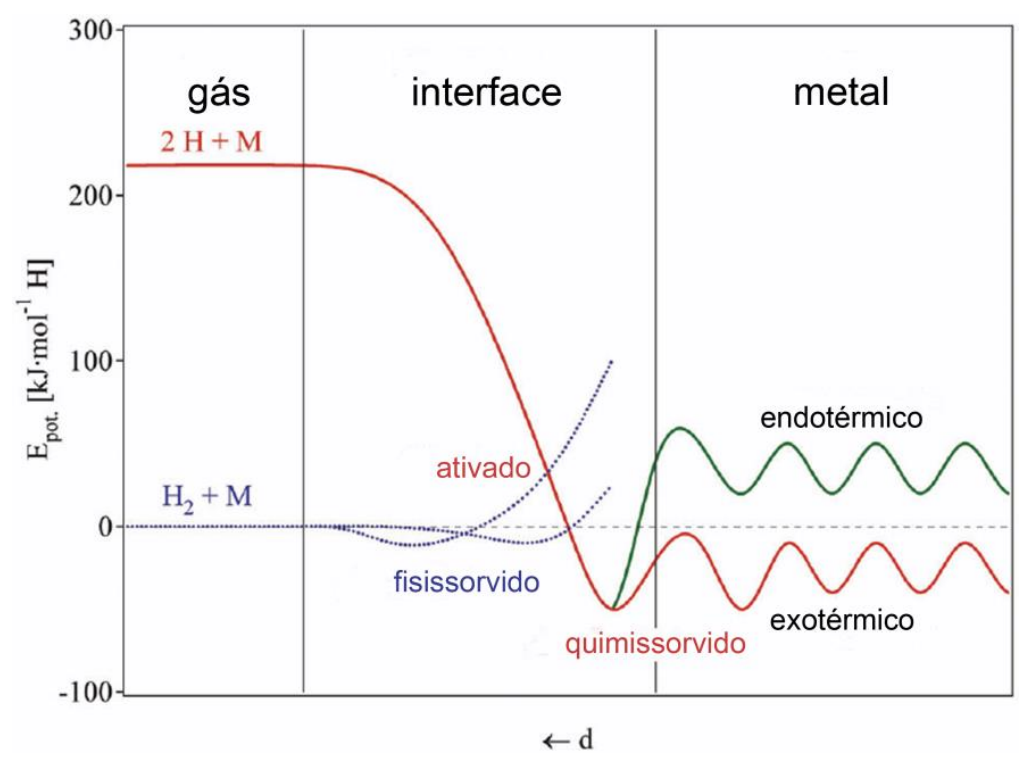

FIGURA 2 - Curva de potencial de Lennard-Jones para a ligação $M-H$ (adaptada) [17].

Após quimissorvido pela superfície metálica, o átomo de hidrogênio ainda tem que superar outra barreira de potencial, relativamente menor no caso de materiais utilizados no armazenamento de hidrogênio, antes que possa se difundir exotermicamente, ou endotermicamente, para o interior do material, formando assim uma solução sólida $\mathrm{M}-\mathrm{H}$, comumente chamada de fase $\alpha$. $\mathrm{O}$ aumento da concentração dos átomos de hidrogênio dentro do material torna 
as interações $\mathrm{H}-\mathrm{H}$ mais relevantes (saturação da fase $\alpha$ ), favorecendo sua difusão para os sítios intersticiais da estrutura cristalina do material, resultando assim na nucleação da fase hidreto (que é o hidreto de metal propriamente dito), que ocorre normalmente sob platô de pressão e temperatura bem definidos, e pode ser chamada de fase $\beta$, ou $\gamma$, dependendo do número de hidretos estáveis formados (ver FIGURA 3) [17, 25]. A nucleação destas fases estáveis garante aos hidretos de metais os mais variados tipos de aplicações na armazenagem sólida de hidrogênio.

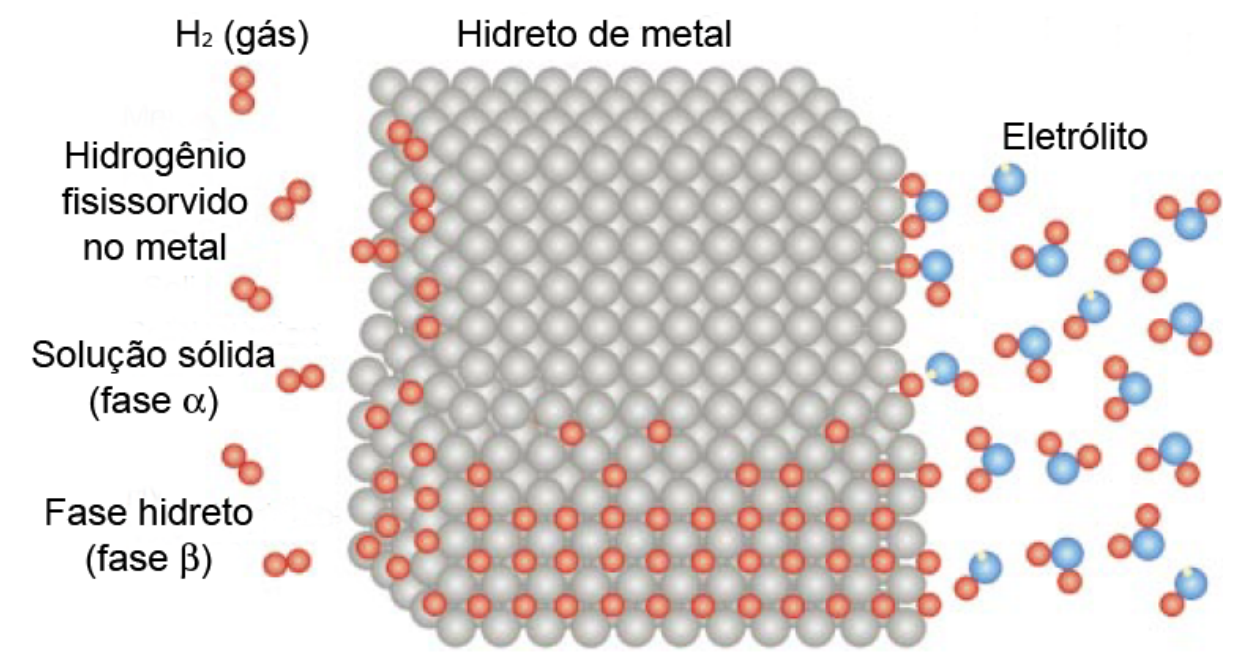

FIGURA 3 - Processo de formação do hidreto de metal (adaptada) [16].

\subsubsection{Aplicações dos hidretos de metais}

Entre as décadas de 40 e 60, os principais estudos acerca dos hidretos estavam quase todos voltados para os efeitos destrutivos do hidrogênio nos metais. Somente na década de 60, com o surgimento da economia do hidrogênio, a utilização de hidretos de metais para fins de armazenamento ganhou destaque [28]. Esta notoriedade, adquirida frente a outras formas de armazenamento de hidrogênio, pode ser justificada, em boa parte, por sua maior segurança, aliada a uma alta densidade de energia volumétrica $(\sim 1,5 \mathrm{kWh} / \mathrm{L})$, destacada na FIGURA 4. Além disso, os hidretos podem se adequar facilmente a diversas aplicações, resultado das suas variadas faixas de operação (pressão e temperatura) [13, 29]. 


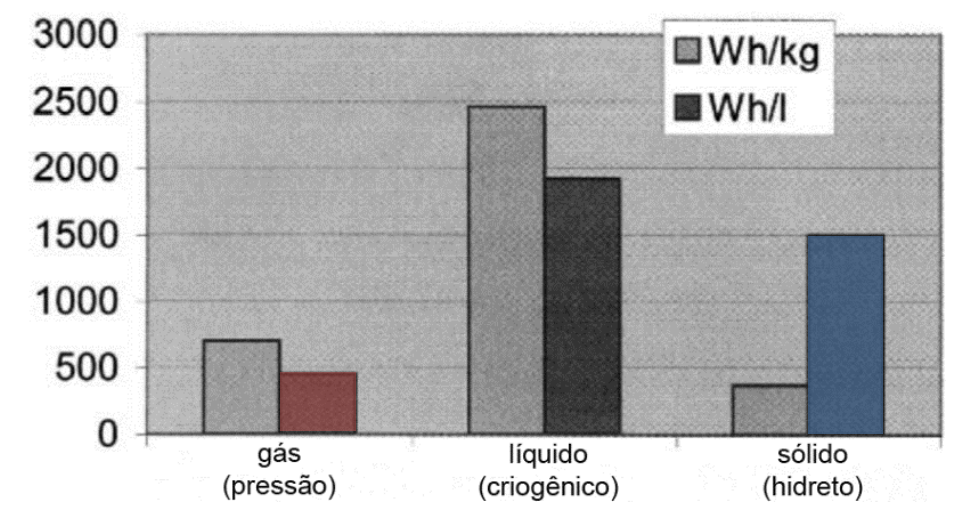

FIGURA 4 - Densidade de energia volumétrica e gravimétrica para diversas formas de armazenamento de hidrogênio [29] (adaptada).

O atual estado da arte desta tecnologia envolve os mais variados tipos de aplicação, onde se destacam os sistemas de reaproveitamento de energia eólica-solar [30], os sistemas de refrigeração [31], os dispositivos armazenadores de energia elétrica e os tanques de armazenamento de hidrogênio, os dois últimos exemplificados na FIGURA 5. Em dispositivos armazenadores de energia elétrica, por exemplo, os hidretos já são utilizados com sucesso desde a década de 90, como eletrodos negativo das baterias de níquel-hidreto de metal (Ni-MH), em substituição as antigas e tóxicas baterias de níquel-cádmio [32-38].

Os hidretos também já foram utilizados com sucesso, ainda na década de 70, como tanque de armazenamento de hidrogênio em automóveis conceito movidos por motores de combustão interna [31, 37, 39, 40]. Neste ponto ainda reside um dos principais obstáculos na penetração dos hidretos de metal no mercado automotivo, sua baixa densidade de energia gravimétrica. Este é o caso, por exemplo, do composto intermetálico TiFe, que possui uma densidade de energia gravimétrica de aproximadamente $0,61 \mathrm{kWh} / \mathrm{Kg}(\sim 1,89 \%$ em massa de $\mathrm{H}_{2}$ ), muito inferior se comparada com os atuais tanques de gasolina, que possuem aproximadamente $11 \mathrm{kWh} / \mathrm{Kg}$ [31, 39]. Entretanto, o crescente desenvolvimento da tecnologia de células a combustível PEM (do inglês "Polymer Electrolyte Membrane") ofereceu uma chance para os sistemas de armazenamento à base de hidretos de metais, principalmente para aplicações de baixa potência, e também para alguns nichos de mercado [29, 41]. Todavia, sua penetração no mercado automotivo ainda é limitada, devido às exigências de valores de ${ }^{2} 1,8 \mathrm{kWh} / \mathrm{Kg}\left(5,5 \%\right.$ em massa de $\left.\mathrm{H}_{2}\right)$ para a densidade de energia 
gravimétrica, o que não é atingido atualmente por nenhum hidreto de metal operando sob baixas pressões ${ }^{2}(0,5-1,2 \mathrm{Mpa})$ e temperaturas próximas a da ambiente $[16,17]$. A difícil penetração neste mercado também tem relação com as baixas cinéticas de absorção e dessorção de hidrogênio apresentadas comumente pelos hidretos. No futuro, se espera que a capacidade máxima de armazenamento de um tanque de hidreto de metal $\left(\sim 5 \mathrm{~kg}\right.$ de $\left.\mathrm{H}_{2}\right)$ possa ser atingida em aproximadamente ${ }^{2} 3,3 \mathrm{~min}$., com uma taxa de absorção não inferior $\mathrm{a}^{2} 1,5 \mathrm{kgH}_{2} / \mathrm{min}$.

${ }^{2}$ Valores esperados pelo U.S. Department of Energy (DOE) até o ano de 2020.

\section{a}

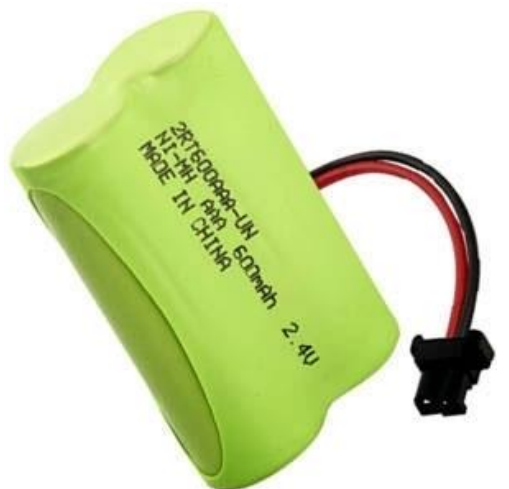

\section{b}

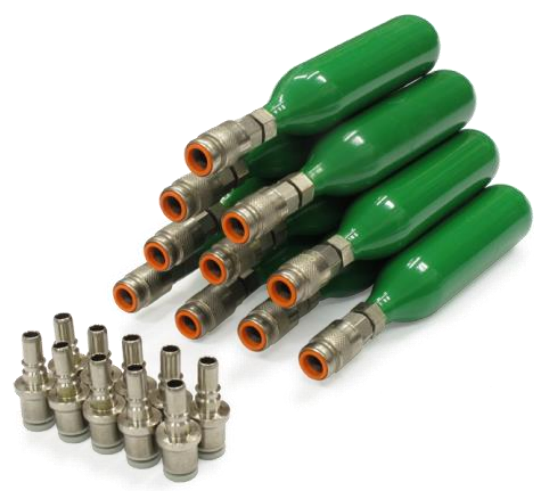

FIGURA 5 - llustrações de algumas das atuais aplicações dos hidretos de metais: (a) Dispositivos armazenadores de energia elétrica (pilhas de $\mathrm{Ni}-\mathrm{MH}$ ); (b) Tanques armazenadores de hidrogênio.

$\mathrm{Na}$ tentativa de cumprir todas estas exigências de mercado, hidretos como o $\mathrm{LaNi}_{5} \mathrm{H}_{6}$, o $\mathrm{ZrV}_{2} \mathrm{H}_{5.5}$, ○ $\mathrm{Mg}_{2} \mathrm{NiH}_{4}$ e o $\mathrm{TiFeH}_{2}$, têm sido alvo de intensas pesquisas na melhora de suas propriedades de armazenamento de hidrogênio. $\mathrm{Na}$ TABELA 1 são apresentadas algumas destas propriedades, onde se observa que o máximo teor em massa de hidrogênio, para os hidretos que 0 liberam em temperaturas próximas a da ambiente, mal se aproxima dos $3 \%$, quando o fazem, caso do hidreto $\mathrm{ZrV}_{2} \mathrm{H}_{5.5}\left(3,01 \%\right.$ em massa de $\left.\mathrm{H}_{2}\right)$, apresentam uma pressão de equilíbrio muito baixa. Os melhores valores neste sentido ainda pertencem ao composto intermetálico TiFe. 
TABELA 1 - Propriedades de armazenamento de hidrogênio em diversos tipos de compostos intermetálicos [42].

\begin{tabular}{ccccccc}
\hline Tipo & Composto & Hidreto & Estrutura & $\begin{array}{c}\text { \% em massa } \\
\text { de } \mathrm{H}_{2}\end{array}$ & $\begin{array}{c}P_{\text {eq }} \\
(\mathrm{MPa})\end{array}$ & $\begin{array}{c}\mathrm{T} \\
(\mathrm{K})\end{array}$ \\
\hline $\mathrm{AB}_{5}$ & $\mathrm{LaNi}_{5}$ & $\mathrm{LaNi}_{5} \mathrm{H}_{6}$ & $P 6 / m m m$ & 1.37 & 0,2 & 298 \\
$\mathrm{AB}_{2}$ & $\mathrm{ZrV}$ & $\mathrm{ZrV}_{2} \mathrm{H}_{5.5}$ & $F d 3 m$ & 3.01 & $10^{-9}$ & 323 \\
$\mathrm{AB}$ & $\mathrm{TiFe}$ & $\mathrm{FeTiH}_{2}$ & $P m 3 m$ & 1.89 & 0,5 & 303 \\
$\mathrm{~A}_{2} \mathrm{~B}$ & $\mathrm{Mg}_{2} \mathrm{Ni}$ & $\mathrm{Mg}_{2} \mathrm{NiH}_{4}$ & $P 6_{2} 22$ & 3.59 & 0,1 & 555 \\
\hline $\mathrm{A}=$ formador de & &
\end{tabular}

\subsubsection{Armazenamento de hidrogênio no composto intermetálico TiFe}

O sistema Ti-Fe, representado no diagrama de fases da FIGURA 6, forma dois compostos intermetálicos estáveis, o $\mathrm{TiFe}$ e $\circ \mathrm{TiFe}_{2}$, de estruturas cúbica simples e hexagonal, respectivamente (ver FIGURA 7). É importante salientar que o TiFe pode não ser exatamente um composto de linha, como mostra o diagrama de fases da FIGURA 6, podendo apresentar, a elevadas temperaturas $\left(1085^{\circ} \mathrm{C}\right)$, um desvio composicional em relação ao valor estequiométrico de até $5 \%$ em excesso de Ti [43], uma questão pouco abordada na literatura.

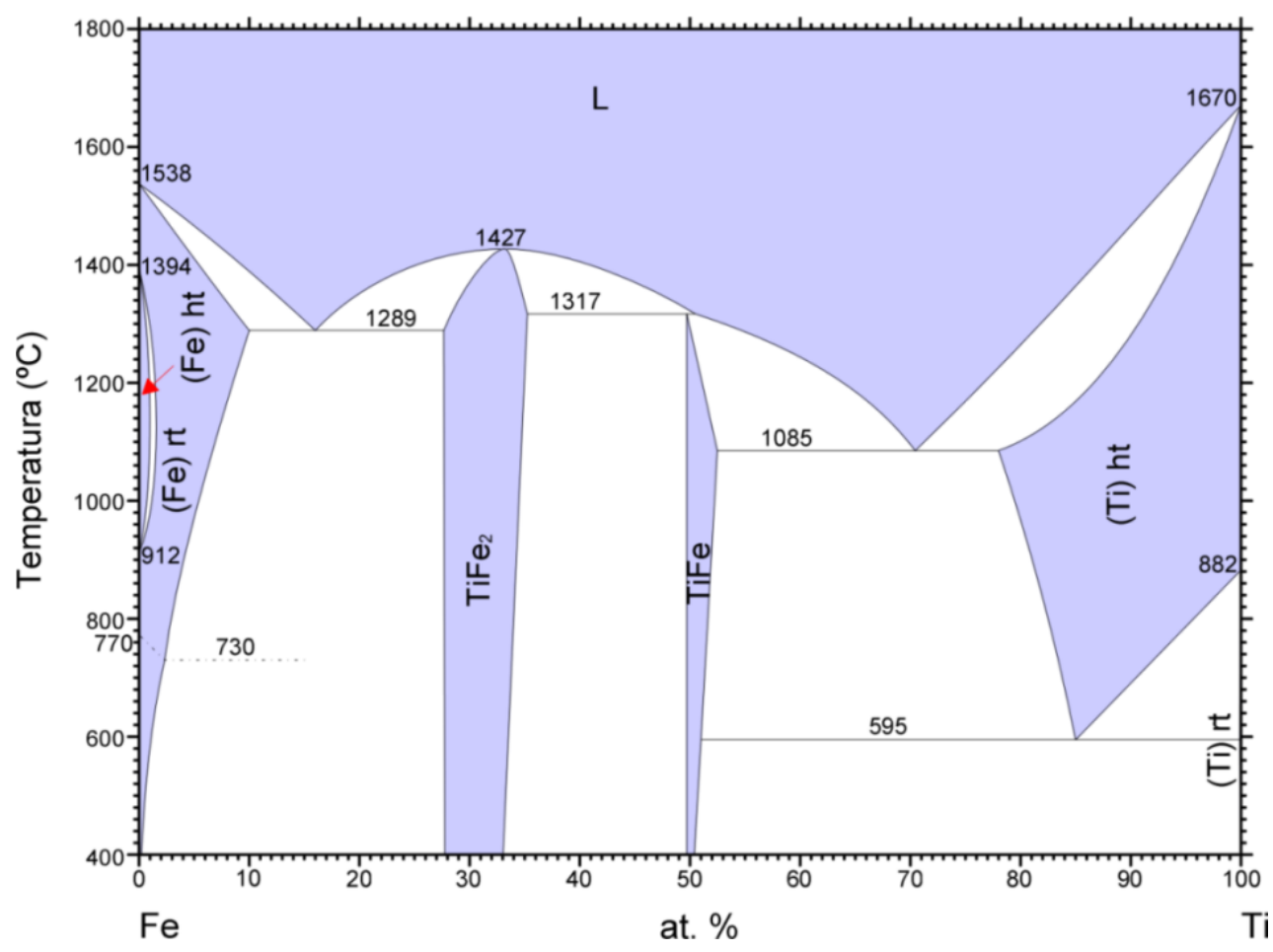

FIGURA 6 - Diagrama de equilíbrio estável de fases do sistema Ti-Fe [43]. 
$\mathrm{O}$ composto $\mathrm{TiFe}_{2}$ não possui propriedades adequadas para 0 armazenamento de hidrogênio. Já o TiFe pode armazená-lo à temperatura ambiente sob os platôs de pressão de 0,4MPa e $1 \mathrm{MPa}$, que correspondem respectivamente a formação dos hidretos metálicos estáveis $\beta \mathrm{TiFeH}$ e $\mathrm{YTiFeH}_{2}$ [2], de estruturas ortorrômbica e monoclínica (ver FIGURA 7). Todavia, quando obtido por processos convencionais, como o de fusão, o TiFe ainda precisa ser ativado antes que possa absorver hidrogênio pela primeira vez à temperatura ambiente [1]. Tipicamente o processo de ativação consiste de tratamentos térmicos lentos e custosos em altas temperaturas e sob elevada pressão de hidrogênio [44]. Ainda assim, o composto pode apresentar uma cinética de absorção e dessorção de hidrogênio reduzida, relacionada à nucleação da própria fase hidreto [25]. Além disso, na forma de lingote (oriundo da fusão), o TiFe pode se decrepitar ao absorver repetidas vezes o hidrogênio, limitando muito sua utilização como armazenador de hidrogênio em aplicações que exijam a manutenção desta forma [45].

As dificuldades supracitadas apresentam em comum a estrutura policristalina do TiFe $(>50 \mathrm{~nm})$, tipicamente formada em processos como o de fusão, o que justifica o interesse de diversos grupos de pesquisa em obter 0 TiFe na forma nanocristalina (nanoestruturada) através de processos não convencionais, como a moagem de alta energia [25, 44, 46, 47]. 
a

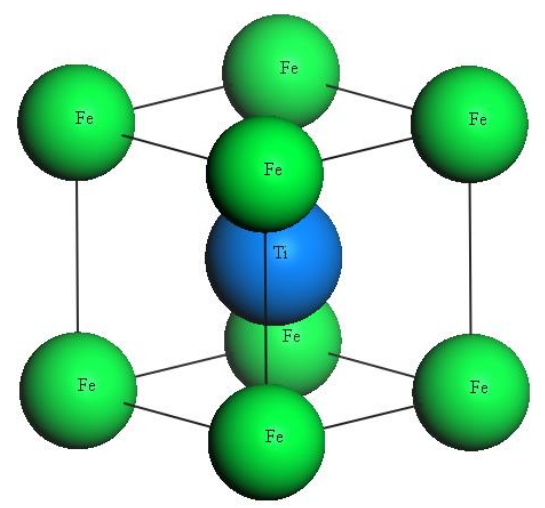

Pm-3m (n-221)

\section{C}

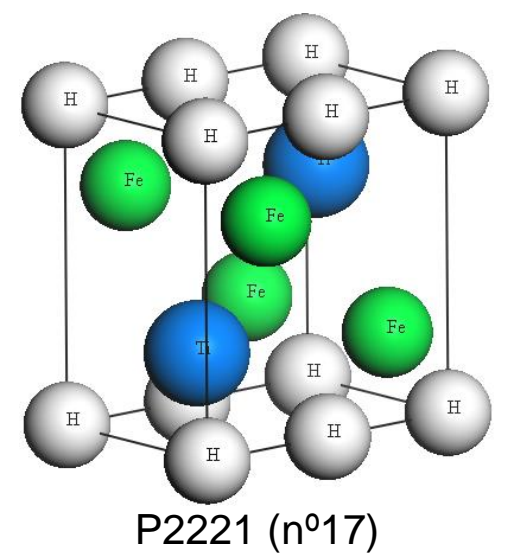

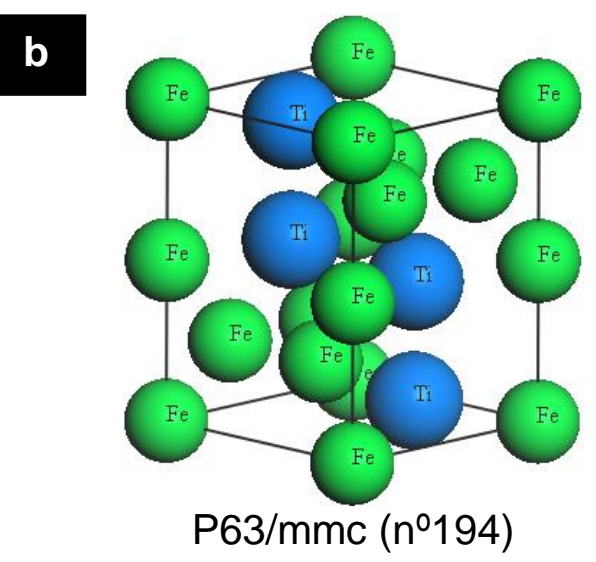

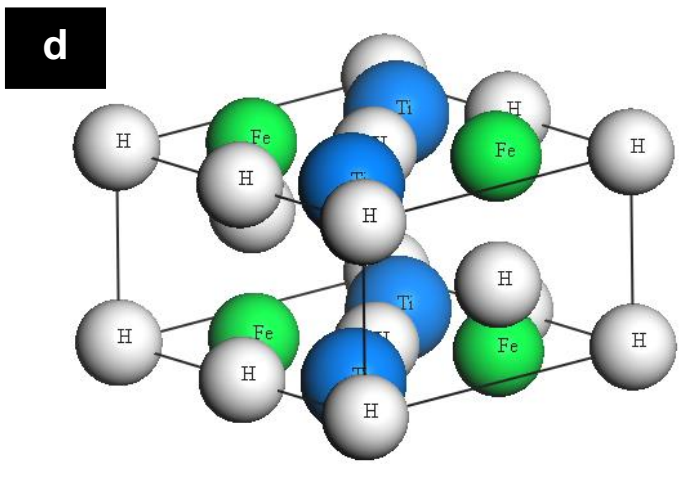

$\mathrm{P} 12 / \mathrm{m} 1$ (no10)

FIGURA 7 - Células unitárias de estruturas cristalinas de materiais citados no texto: (a) TiFe (ICSD 633950); (b) $\mathrm{TiFe}_{2}$ (ICSD 657043); (c) $\mathrm{TiFeH}$ (ICSD 602022); (d) $\mathrm{TiFeH}_{2}$ (ICSD 601978).

\subsection{Moagem de alta energia de compostos intermetálicos}

Inicialmente empregada para produzir uma melhor dispersão de fases cerâmicas em superligas (Dispersão Mecânica), a moagem de alta energia também possibilita a síntese de diversos tipos de compostos intermetálicos a partir da mistura de seus pós elementares [48, 49]. Para tal fim, várias rotas de moagem podem ser adotadas, tais como o aumento da reatividade química da mistura dos pós (Moagem Mecânica) seguido de um tratamento térmico, a difusão ativada por deformação (Elaboração Mecânica) e a reação de combustão in situ (Moagem Reativa) [3, 50-52]. Além disso, já se demonstrou que a utilização da moagem de alta energia pode facilitar a adsorção física, a quimissorção e a difusão de hidrogênio em compostos intermetálicos moídos, devido à obtenção de maior área de superfícies novas e reativas, da maior densidade de defeitos cristalinos, bem como de mistura de fases amorfa e nanocristalina [25, 44, 47]. 
O processo de moagem de alta energia de compostos intermetálicos envolve uma série de estágios (FIGURA 8), já descritos com precisão ainda na década de 70 por Benjamim e Volin (1974) [53]. No estágio inicial da moagem, as partículas dos pós elementares são deformadas plasticamente e soldadas a frio umas nas outras, resultando na formação de agregados de partículas maiores. Já em um estágio intermediário, ocorre um aumento do encruamento e da resistência mecânica dos agregados, o que aumenta a probabilidade de fratura, resultando em uma redução do tamanho de partículas (aumento da área de contato entre os pós). No estágio final da moagem, a soldagem e a fratura das partículas entram em equilíbrio, resultando nos refinamentos da microestrutura dos agregados (entre 10 e $50 \mathrm{~nm}$ ) e do tamanho de partículas

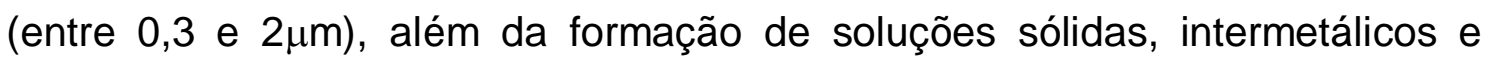
fases amorfas. Excelentes revisões sobre $o$ assunto podem ser encontradas na literatura pertinente $[25,52,54]$.

Durante o processo de moagem é comum, em razão dos fortes e frequentes impactos das bolas no recipiente de moagem e entre si, que partículas mais dúcteis dos pós exibam forte tendência à soldagem mútua e aderência ao ferramental de moagem. $O$ controle desta soldagem e aderência é normalmente feito pela adição de substâncias conhecidas como Agentes Controladores de Processo (ACPs). Tais controladores são normalmente compostos orgânicos, que podem ser adicionados nos estados sólido, líquido ou gasoso, em quantidades que variam tipicamente entre 1 e $5 \%$ em massa da mistura dos pós de partida. Dentre os ACPs mais comumente empregados, podemos citar 0 ácido esteárico $\left[\mathrm{CH}_{3}\left(\mathrm{CH}_{2}\right){ }_{16} \mathrm{COOH}\right]$, o heptano $\left[\mathrm{CH}_{3}\left(\mathrm{CH}_{2}\right)_{5} \mathrm{CH}_{3}\right]$, o poli(etileno-glicol) $\left[\mathrm{H}\left(\mathrm{OCH}_{2} \mathrm{CH}_{2}\right)_{n} \mathrm{OH}\right]$, o hexano [ $\left.\mathrm{CH}_{3}\left(\mathrm{CH}_{2}\right)_{4} \mathrm{CH}_{3}\right]$, o metanol [ $\left.\mathrm{CH}_{3} \mathrm{OH}\right]$ e o etanol $\left[\mathrm{C}_{2} \mathrm{H}_{5} \mathrm{OH}\right][52,54]$. 
Muitas variáveis podem influenciar o resultado final de uma moagem, sendo o seu controle de suma importância para o sucesso da moagem.

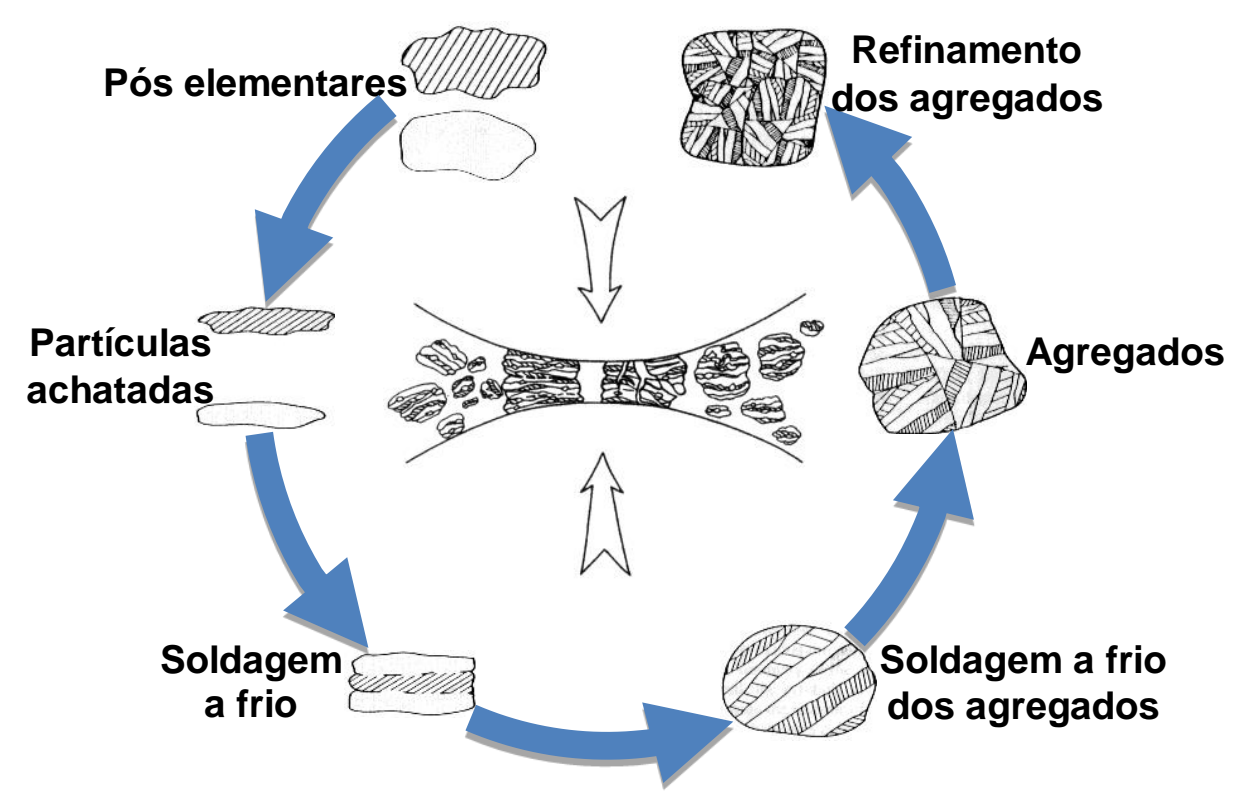

FIGURA 8 - Principais estágios envolvidos no processo de moagem de alta energia [48, 53, 55] (adaptada).

\subsubsection{Variáveis do processo de moagem de alta energia}

A moagem de alta energia é reconhecidamente um processo que envolve um grande número de variáveis, onde se destacam o tipo de moinho (tipo de refrigeração do recipiente de moagem, velocidade de rotação do prato e dimensões do moinho), a atmosfera de moagem (tipicamente um gás inerte para evitar a contaminação dos pós durante a moagem), o tipo e quantidade de ACP (controle da soldagem a frio), a razão bola:pó (razão entre as massas das bolas e dos pós), o ferramental de moagem (materiais, dimensões e preenchimento do recipiente de moagem), os materiais de partida (dureza e tamanho inicial de partículas) e o tempo de moagem. Revisões sobre a influência das variáveis pertinentes ao processo de moagem podem ser facilmente encontradas na literatura [52, 54].

Cada uma destas variáveis, bem como seus $n$-arranjos possíveis, tem grande influência sobre o processo de moagem, o que por muitas vezes dificulta a tarefa de reproduzir, ou simplesmente de comparar, os diferentes resultados obtidos da literatura. Neste sentido, podem ser empregados modelos matemáticos capazes de integrar algumas destas variáveis, como o modelo 
simplificado proposto por Burgio et al. (1990), e modificado por Murty et al. (1995), para um moinho do tipo planetário [56, 57]. Maiores detalhes sobre este modelo podem ser encontrados no APÊNDICE A deste trabalho. Já com respeito especificamente a moagem de alta energia do composto TiFe, a TABELA 2 resume algumas das variáveis do processo encontradas em referências selecionadas dos últimos 5 anos. Surpreendentemente, como regra geral, ainda há uma falta de informações sobre algumas destas variáveis, tornando a reprodutibilidade dos resultados uma tarefa praticamente impossível.

\subsection{Obtenção do composto TiFe por moagem de alta energia e suas propriedades no armazenamento de hidrogênio}

Há muitas décadas a moagem de alta energia tem sido empregada com sucesso na obtenção do composto intermetálico TiFe, já com excelentes propriedades para armazenar o hidrogênio. De fato, diversos autores já observaram que as partículas moídas do pó de TiFe, tanto as obtidas pela moagem dos pós elementares, quanto as do composto já previamente fundido, apresentam maior área de superfícies novas e reativas, maior densidade de defeitos cristalinos, bem como mistura de fases amorfa e nanocristalina. Tais características são comumente associadas a uma melhora nas propriedades de armazenamento de hidrogênio, seja na ativação (materiais já ativos ou mais facilmente reativáveis), na cinética (maiores taxas de absorção e dessorção de hidrogênio) ou nos platôs de pressão (relativamente mais baixos) [2, 4, 25, 44, 47]. Há que ressaltar, entretanto, que diversos autores também já relataram uma sensível perda na capacidade reversível de armazenamento de hidrogênio, ou mesmo uma dificuldade na formação da fase $\gamma \mathrm{TiFeH}_{2}$, em materiais moídos que apresentavam muitas das características supracitadas [2, 4, 44]. 
TABELA 2 - Variáveis do processo de moagem do composto TiFe em referências selecionadas dos últimos 5 anos.

\begin{tabular}{|c|c|c|c|c|c|c|}
\hline $\begin{array}{c}\text { Variáveis do processo/ } \\
\text { Referências }\end{array}$ & {$[36]$} & {$[5]$} & [58] & [59] & {$[60]$} & {$[61]$} \\
\hline Materiais de partida & $\begin{array}{l}\text { Pós elementares } \\
(\mathrm{Ti}+\mathrm{Fe}+\mathrm{Co}+\mathrm{Ni})\end{array}$ & $\begin{array}{l}\text { Pós elementares } \\
(\mathrm{Ti}+\mathrm{Fe})\end{array}$ & $\begin{array}{l}\text { Pós elementares } \\
(\mathrm{Ti}+\mathrm{Fe})\end{array}$ & $\begin{array}{l}\text { Pó de TiFe } \\
\text { (Fundido) }\end{array}$ & $\begin{array}{l}\text { Pós elementares } \\
\quad\left(\mathrm{TiH}_{2}+\mathrm{Fe}\right)\end{array}$ & $\begin{array}{l}\text { Pó de TiFe } \\
\text { (Fundido) }\end{array}$ \\
\hline $\begin{array}{l}\text { Tamanho inicial de } \\
\text { partículas }\end{array}$ & $?$ & $\begin{array}{c}50<\mathrm{Ti}<100 \mu \mathrm{m} \mathrm{e} \\
5<\mathrm{Fe}<10 \mu \mathrm{m}\end{array}$ & $\begin{array}{c}50<\mathrm{Ti}<100 \mu \mathrm{m} \mathrm{e} \\
5<\mathrm{Fe}<10 \mu \mathrm{m}\end{array}$ & $\mathrm{TiFe}<125 \mu \mathrm{m}$ & $\begin{array}{c}\mathrm{TiH}_{2}<44 \mu \mathrm{m} \mathrm{e} \\
\mathrm{Fe}<44 \mu \mathrm{m}\end{array}$ & $50<\mathrm{TiFe}<150 \mu \mathrm{m}$ \\
\hline Tipo de moinho & $\begin{array}{l}\text { Planetário } \\
\left.\text { (Fritsch }{ }^{\circledR} \mathrm{P} 5\right)\end{array}$ & $\begin{array}{l}\text { Planetário } \\
\text { (AGO-2S) }\end{array}$ & $\begin{array}{l}\text { Planetário } \\
\text { (AGO-2C) }\end{array}$ & $\begin{array}{c}\text { Agitador } \\
\left(\text { Spex }^{\circledR} 8000\right)\end{array}$ & $\begin{array}{l}\text { Planetário } \\
\left.\text { (Fritsch }{ }^{\circledR} \mathrm{P} 5\right)\end{array}$ & $\begin{array}{l}\text { Planetário } \\
\left.\text { (Fritsch }{ }^{\circledR} \mathrm{P} 7\right)\end{array}$ \\
\hline Rotação do moinho & 200rpm & 620 e 840 rpm & 840rpm & n.a. & $300 \mathrm{rpm}$ & 200rpm \\
\hline Recipiente de moagem & $\begin{array}{c}\text { Aço inoxidável } \\
(?)\end{array}$ & $\begin{array}{c}\text { Aço (?) } \\
(?)\end{array}$ & $\begin{array}{l}\text { Aço inoxidável } \\
(\mathrm{V}=?)\end{array}$ & $\begin{array}{l}\text { WC } \\
(\mathrm{V}=?)\end{array}$ & $\begin{array}{l}\text { Aço inoxidável } \\
\left(\mathrm{V}=250 \mathrm{~cm}^{3}\right)\end{array}$ & $\begin{array}{l}\text { Aço inoxidável } \\
\left(\mathrm{V}=34 \mathrm{~cm}^{3}\right)\end{array}$ \\
\hline Bolas de moagem & $\begin{array}{c}\text { Aço inoxidável } \\
\text { (?) }\end{array}$ & $\begin{array}{c}\text { Aço (?) } \\
(\varnothing=4 \mathrm{~mm})\end{array}$ & $\begin{array}{l}\text { Aço inoxidável } \\
(\varnothing=4 \mathrm{~mm})\end{array}$ & $\begin{array}{c}\text { Aço inoxidável } \\
(\varnothing=?)\end{array}$ & $\begin{array}{l}\text { Aço inoxidável } \\
(\varnothing=8 \mathrm{~mm})\end{array}$ & $\begin{array}{c}\text { Aço inoxidável } \\
(\varnothing=7 \mathrm{~mm})\end{array}$ \\
\hline Razão bola:pó & $15: 1$ & $10: 1$ & $10: 1$ & $4: 1$ & $20: 1$ & $4: 1$ \\
\hline Tempo de moagem & 15 a 30 horas & $\begin{array}{l}10 \text { a } 120 \\
\text { minutos }\end{array}$ & 2 horas & 5 horas & 5 a 40 horas & 36 horas \\
\hline Atmosfera de moagem & $\begin{array}{l}\text { Argônio } \\
\text { purificado }\end{array}$ & Argônio & Argônio & Argônio & $\begin{array}{l}\text { Argônio } \\
\text { purificado }\end{array}$ & Argônio \\
\hline ACP & n.r. & n.r. & n.r. & Metanol & $\begin{array}{c}\text { Sem ACP } \\
\text { orgânico }\left(\mathrm{TiH}_{2}\right)\end{array}$ & Acetona \\
\hline
\end{tabular}


Diferentes rotas de processo podem ser utilizadas na síntese do TiFe por moagem de alta energia, a destacar, a elaboração mecânica (EM) a partir dos pós elementares de Ti e Fe, a moagem mecânica (MM) do pó de TiFe, já previamente fundido e homogeneizado, além da moagem mecânica dos pós elementares de Ti e Fe seguida da síntese do composto por reação.

\subsubsection{Rota de elaboração mecânica (EM)}

Na rota de elaboração mecânica (EM) do composto TiFe, em uma linha do tempo selecionada a partir da década de 90, diversos autores estudaram a influência do tempo e da atmosfera de moagem nas propriedades de armazenagem de hidrogênio [2-8]. É importante salientar que o tempo e a atmosfera de moagem foram escolhidos apenas para contextualizar a obtenção do TiFe nas diferentes referências selecionadas. Uma comparação direta entre os resultados envolveria uma série de outras variáveis, além de modelos matemáticos capazes de integrá-las, algo que já havia sido discutido anteriormente. Contudo, os efeitos da moagem nas propriedades de armazenamento de hidrogênio poderão ser analisados sem maiores problemas.

Posto isso, ainda na década de 90, Zaluski et al. (1993) relataram a elaboração mecânica do TiFe nanocristalino (entre 5 e $7 \mathrm{~nm}$ ) após 68 horas de moagem em uma atmosfera controlada de argônio com menos de $3 \%$ at. de oxigênio. Entretanto, quando o material moído foi exposto sucessivas vezes à mesma atmosfera (procedimento normalmente utilizado na retirada de alíquotas do pó para posteriores análises) se observou apenas a presença da fase amorfa (após $22 \mathrm{~h}$ de moagem), com cerca $3.6 \%$ at. de oxigênio dissolvido. Já quando a moagem foi realizada em atmosfera de argônio com mais de 10\% at. de oxigênio, foi verificada apenas a estrutura amorfa de composição $\mathrm{Ti}_{66} \mathrm{Fe}_{34}$ (após 13h de moagem), com 5.3\% at. de oxigênio dissolvido. Tais resultados deixam claro que 0 processo de moagem pode aumentar sobremaneira a reatividade do material com oxigênio, sendo o seu controle de fundamental importância na síntese do TiFe.

Zaluski et al. (1993) verificaram também que o TiFe nanocristalino, resultante da moagem por 68 horas, ainda precisava ser ativado termicamente antes que pudesse absorver hidrogênio pela primeira vez à temperatura 
ambiente. Uma vez ativado, o material absorveu hidrogênio sob o platô de aproximadamente $0.7 \mathrm{MPa}$, sendo sua capacidade máxima de armazenagem, expressa aqui pela relação $\mathrm{H}: \mathrm{TiFe} \sim 1,05$, atingida a pressão de $2,5 \mathrm{MPa}$. Segundo os autores, tais resultados são típicos para um material moído que apresenta uma mistura de fases amorfa e nanocristalina (quantidades significativas de hidrogênio absorvidas em platôs relativamente mais baixos de pressão).

Os resultados apresentados por Zaluski et al. (1993) mostram que mesmo atmosferas pobres em oxigênio $\left(<3 \%\right.$ at. de $\left.\mathrm{O}_{2}\right)$ podem desativar $\mathrm{O}$ TiFe elaborado mecanicamente, seja durante a própria moagem, ou posteriormente no carregamento do reator onde são realizados os experimentos com hidrogênio, fenômeno que está intimamente ligado ao aumento da reatividade com oxigênio (assim como com hidrogênio) durante a moagem. Outros autores também já haviam verificado a desativação do composto na presença de oxigênio, onde foi relatado que uma fina camada superficial de óxido seria a responsável por inibir a dissociação $\left(\mathrm{H}_{2} \rightarrow 2 \mathrm{H}\right)$ e a subsequente difusão de hidrogênio para 0 interior do composto [27, 62]. $A$ questão da atividade do TiFe é recorrente na literatura, e deverá ser analisada posteriormente em conjunto com os resultados obtidos pelos demais autores.

Também na rota de elaboração mecânica, Novakova et al. (1998) constataram, nos estágios iniciais da moagem ( $2 \mathrm{~h}$ de moagem), a presença das fases desordenadas $\mathrm{TiFe}$ e $\mathrm{TiFe}_{2}$, além das soluções sólidas $\alpha \mathrm{Fe}(\mathrm{Ti})$ e $\beta \mathrm{Ti}(\mathrm{Fe})$. Já em estágios mais avançados da moagem (22 e 36h de moagem), prevaleceu a formação das fases desordenadas TiFe e TiFe 2 . Após a análise térmica diferencial (DTA) do material moído por 36 horas, os autores observaram um pico exotérmico em aproximadamente $600^{\circ} \mathrm{C}(873 \mathrm{~K})$, atribuído à ordenação das fases TiFe e $\mathrm{TiFe}_{2}$ (FIGURA 9), que cresceram as custas das fases $\beta \mathrm{Ti}(\mathrm{Fe})$ e $\alpha \mathrm{Fe}$ (proveniente do desgaste do ferramental de moagem). Também foi observado um segundo pico exotérmico, em aproximadamente $720^{\circ} \mathrm{C}(993 \mathrm{~K})$, atribuído à transformação da fase TiFe nas fases $\mathrm{TiFe}_{2}$ e $\alpha \mathrm{Ti}$. Neste ponto reside uma dúvida, visto que, o diagrama de fases estáveis do sistema Ti-Fe (ver FIGURA 6) não apresenta essa suposta transformação. A explicação talvez esteja nas observações feitas por diversos autores ao 
exporem o composto TiFe a atmosferas ricas em oxigênio [63, 64]. Schober (1983), por exemplo, verificou que a oxidação do composto TiFe podia levar à formação de outras fases, tais como $\mathrm{TiFe}_{2}$ e $\mathrm{TiO}_{2}$, o que esclareceria os resultados observados por Novakova et al. (1998).

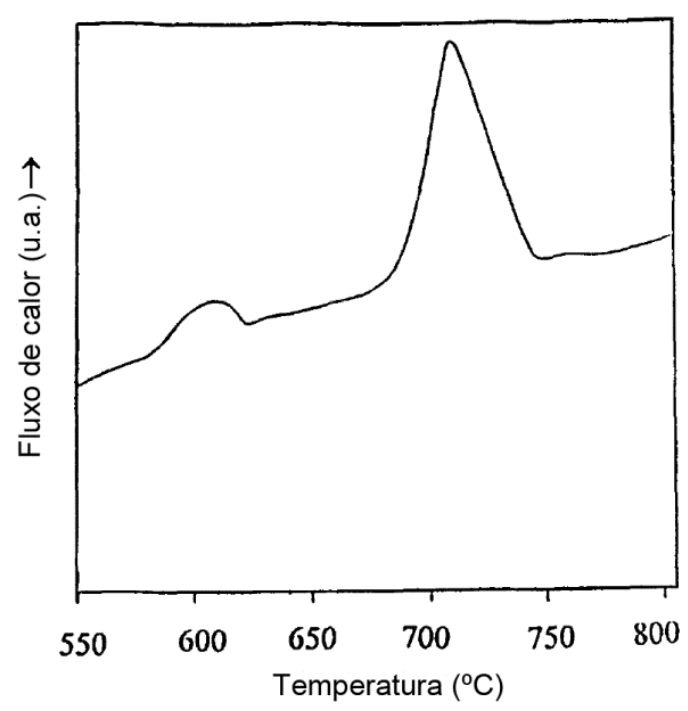

FIGURA 9 - Termograma (DTA) do material moído por 36 horas [7].

Ainda na rota de elaboração mecânica, mas utilizando os pós de $\mathrm{TiH}_{2} \mathrm{e}$ Fe como materiais de partida, Novakova et al. (2000) constataram, nos estágios iniciais da moagem ( $2 \mathrm{~h}$ de moagem), a presença majoritária da solução sólida $\mathrm{Fe}(\mathrm{Ti}, \mathrm{H})$ e de pequenas quantidades da solução sólida $\mathrm{TiH}_{2-x}(\mathrm{Fe})$ e $\mathrm{TiFeH}_{1-\mathrm{x}}$, bem como das fases hidreto $\beta \mathrm{TiFeH}$ e $\gamma \mathrm{TiFeH}_{2}$. Nos estágios intermediários de moagem (de 2 até $36 \mathrm{~h}$ ), foi observada uma crescente diminuição da solução sólida $\mathrm{Fe}(\mathrm{Ti}, \mathrm{H})$, seguido de um aumento significativo das fases $\beta \mathrm{TiFeH}$ e $\mathrm{TiH}_{2-x}(\mathrm{Fe})$, que permaneceram quase que inalteradas após 22 horas de moagem. No estágio final da moagem (de 36 até $60 \mathrm{~h}$ ), se observaram maiores porcentagens das fases $\beta \mathrm{TiFeH}$ e $\mathrm{TiH}_{2-x}(\mathrm{Fe})$. Após a moagem por 60 horas, os pós moídos apresentaram agregados de partículas da ordem de alguns $\mu \mathrm{m}$ que, segundo os próprios autores, eram menores do que aqueles obtidos nas moagens pelos mesmos tempos dos pós de $\mathrm{Ti}$ e $\mathrm{Fe}$ em trabalho anterior [7], o que pode ser justificado em boa parte pela maior fragilidade da fase hidreto $\left(\mathrm{TiH}_{2}\right)$. A questão do tamanho médio de partículas 
dos pós moídos também é recorrente na literatura, e deverá ser analisada posteriormente em conjunto com os resultados obtidos pelos demais autores.

Os resultados expostos por Novakova et al. (2000) mostram que induzir a primeira absorção de hidrogênio in situ, isto é, dentro do recipiente onde o composto foi elaborado mecanicamente, pode ser uma boa alternativa para contornar o problema da desativação já observado por Zaluski et al. (1993). Contudo, o crescente aumento da solução sólida $\mathrm{TiH}_{2-x}(\mathrm{Fe})$ ao longo das moagens também indica que a fase TiFe poderia não ser formada majoritariamente. Em vista disso, ainda se busca uma rota de processo que possa sintetizar um material já ativo, contendo majoritariamente a fase TiFe, uma questão não abordada por estes autores.

Seguindo o exemplo dos demais autores, Abe e Kuji (2007) também verificaram a elaboração mecânica do composto TiFe após 10 horas de moagem. Foi relatado também um maior grau de amorfização (perda da cristalinidade) nos materiais moídos por 5 e 20 horas, caracterizada pelo alargamento do perfil dos picos de difração, seguido por uma recristalização parcial da fase TiFe após 10, 15 e 40 horas de moagem (FIGURA 10a), além de um aumento significativo, em particular para o material moído por 20 horas, da contaminação por cromo $(\mathrm{Cr})(4,7 \%$ at. de $\mathrm{Cr}$, proveniente do desgaste do ferramental de moagem) e da aderência dos pós ao ferramental de moagem (diminuição do rendimento do processo). Com relação à aderência dos pós, foram observados rendimentos inferiores a 10\% em massa após as moagens (10, 15 e 40h). Tal comportamento foi associado a um aumento da fase cristalina TiFe nos materiais moídos, uma vez que, os rendimentos para os materiais que apresentavam uma maior parcela da fase amorfa foram superiores a $80 \%$ em massa ( 5 e $20 \mathrm{~h}$ ), como mostra a FIGURA 10c. Antes do relato destes autores, a questão da aderência dos pós de $\mathrm{Ti}$ e $\mathrm{Fe}$ ao ferramental de moagem não havia sido abordada de forma clara na literatura consultada. Somente López-Báez et al. (2006) já haviam dado indícios sobre este problema, mencionando um procedimento de pré-revestimento do ferramental de moagem (com os próprios pós de $\mathrm{Ti}$ e $\mathrm{Fe}$ ). O fenômeno da aderência é bem conhecido das rotas de moagem de alta energia [52,54] e de fundamental importância para o sucesso da moagem, uma questão que ainda será analisada juntamente com os relatos dos demais autores. 
Abe e Kuji (2007) avaliaram ainda a morfologia e o tamanho de partículas (ou agregados) dos materiais moídos por 5, 10 e 20 horas. Nos estágios iniciais da moagem (5 e 10h), foram observados partículas achatadas e menores que $100 \mu \mathrm{m}$, que em um estágio mais avançado (20h) se agregaram em partículas mais arredondadas de aproximadamente $10 \mu \mathrm{m}$. Uma questão não abordada pelos autores após as moagens, pelo menos não de maneira explícita, refere-se à composição química dos pós moídos. Em princípio, os materiais moídos deveriam apresentar a composição química estequiométrica do composto $\mathrm{TiFe}(50 \%$ at. de $\mathrm{Ti}$ e $50 \%$ at. de $\mathrm{Fe}$ ), contudo, foram relatados após as moagens desvios composicionais entre 3 e 17\% at. em excesso de Ti, indícios de que a mistura inicial dos pós elementares feita pelos autores pode não ter sido exatamente na proporção estequiométrica do composto TiFe (apresentava um excesso de Ti). Os parâmetros de rede do TiFe obtido nas moagens por 10 e 40 horas $(0,2982$ e 0,2987nm, respectivamente) acompanhavam essa tendência, em desacordo com o esperado para a fase TiFe de composição estequiométrica (0,2976nm). Outros autores já haviam associado esta discrepância a um excesso de Ti em solução no TiFe, comumente representado por $\mathrm{TiFe}(\mathrm{Ti})[44,65]$.

Após as moagens, Abe e Kuji (2007) submeteram os materiais moídos, por 10 e 40 horas, a um tratamento térmico (573K sob vácuo por 3 h), antes que estes pudessem absorver hidrogênio pela primeira vez à temperatura ambiente (o próprio autor não caracteriza tal procedimento como um ciclo de ativação térmica). Após o tratamento, o material moído por 10 horas absorveu hidrogênio $(99,99999 \%$ de pureza) sob o platô de pressão de aproximadamente $0,4 \mathrm{MPa}$, sendo que a capacidade máxima de armazenamento de $\mathrm{H}: \mathrm{Ti}+\mathrm{Fe}=0,56\left(1,09 \%\right.$ em massa de $\left.\mathrm{H}_{2}\right)$ foi atingida a pressão de 5MPa. Já o material moído por 40 horas absorveu hidrogênio sob o platô de pressão de aproximadamente $0,17 \mathrm{MPa}$, com capacidade máxima de $\mathrm{H}: \mathrm{Ti}+\mathrm{Fe} \sim 0,44 \quad\left(\sim 0,86 \%\right.$ em massa de $\left.\mathrm{H}_{2}\right)$ atingida a uma pressão de aproximadamente 2MPa (FIGURA 10b). Foi verificado ainda que nem todo hidrogênio absorvido pelos materiais moídos podia ser dessorvido após a primeira ciclagem $(\mathrm{H}: \mathrm{Ti}+\mathrm{Fe} \sim 0,22$ e $\mathrm{H}: \mathrm{Ti}+\mathrm{Fe} \sim 0,25$, respectivamente para 10 e 40h de moagem). Quando estes resultados são confrontados diretamente, se observa que o material moído por 40 horas apresentou uma maior perda na 
capacidade de armazenamento reversível, bem como platôs mais baixos de absorção (ou de dessorção) de hidrogênio, fenômenos que parecem estar relacionados com os maiores grau de amorfização e variação composicional da fase TiFe (excesso de Ti em solução sólida no TiFe) [44].
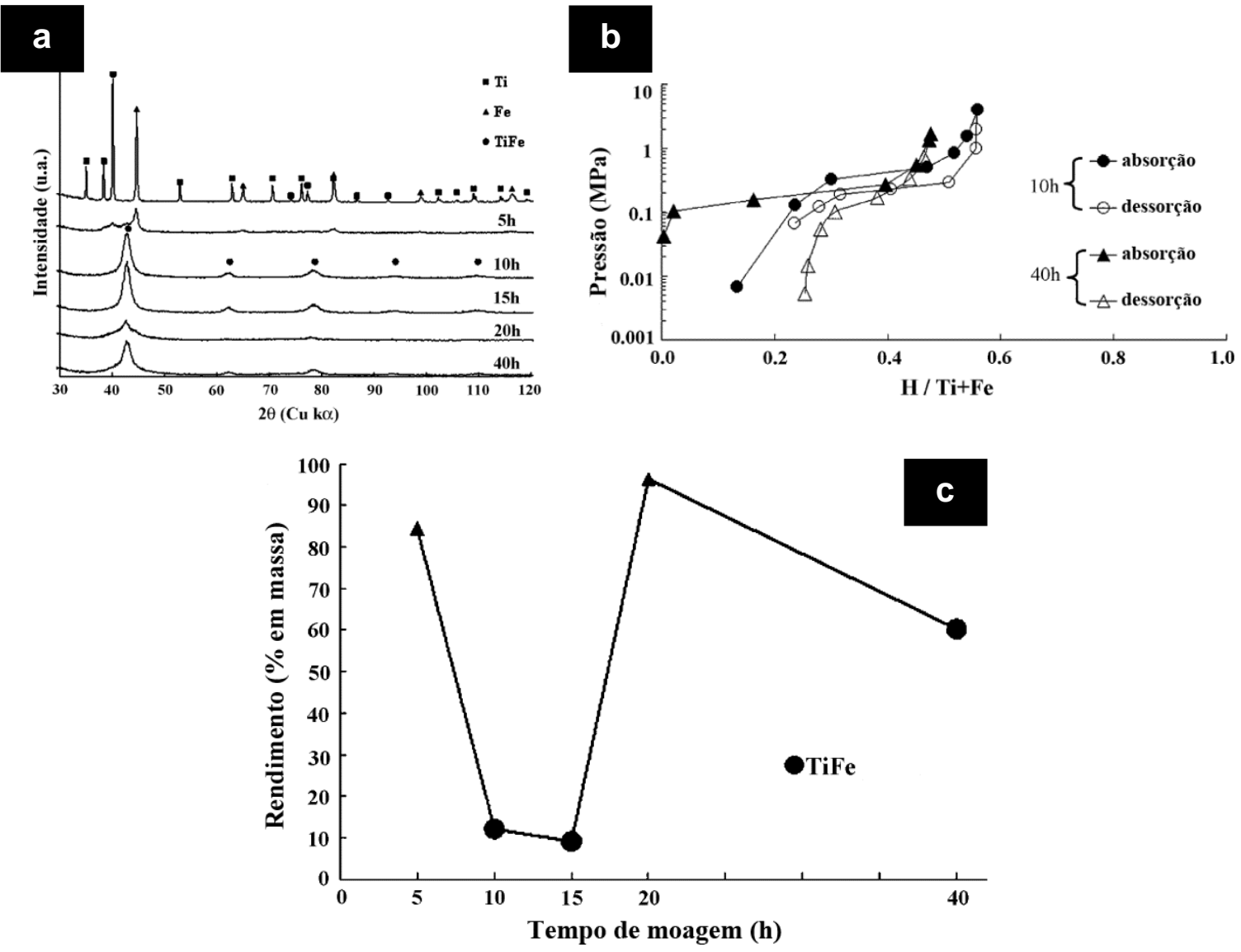

FIGURA 10 - (a) Difratogramas de raios $X$ (DRX) dos materiais moídos por diferentes tempos; (b) Curvas PCTs (Pressão-Composição e Temperatura) a temperatura constante de $303 \mathrm{~K}$ para o TiFe elaborado mecanicamente após 10 e 40 horas de moagem; (c) Rendimentos do processo após diferentes tempos de moagem [3].

A ideia de um material já ativado após as moagens, exposta por Abe e Kuji (2007), corrobora as observações já feitas por Novakova et al. (2000). Contudo, os mecanismos que mantiveram o TiFe ativo nestes casos parecem ser distintos. No caso de Novakova et al. (2000), o fato de não expor o TiFe a uma atmosfera renovada após as moagens (a primeira absorção de hidrogênio foi realizada in situ e não em um reator) parece ter evitado a desativação. Já no caso de Abe e Kuji (2007), onde o TiFe foi exposto à atmosfera não controlada (ao ar) após as moagens, a questão da composição química do material moído 
pode ter tido grande influência sobre a ativação, resultado que ainda deve ser avaliado posteriormente em conjunto com os obtidos pelos demais autores.

Hotta et al. (2007) também confirmaram a elaboração mecânica do composto após 20 horas de moagem. Além disso, foi observada uma crescente amorfização do material moído com o aumento do tempo de moagem (de 2,5 até 10h), seguida de uma recristalização da fase TiFe após 20 horas de moagem (ver FIGURA 11a). Segundo os autores, o material moído por 20 horas apresentava majoritariamente a fase TiFe nanocristalina (entre 5 e $10 \mathrm{~nm}$ ), resultado confirmado por microscopia eletrônica de transmissão (MET), como mostra a FIGURA 11c. Além disso, a composição química do material moído se mostrou bem próxima à estequiométrica do TiFe $(49,1 \%$ de $\mathrm{Ti}$ e $50,9 \%$ at. de $\mathrm{Fe}$ ), como também indicou a medida do parâmetro de rede da fase TiFe $(0,2978 \mathrm{~nm})$.

Hotta et al. (2007) verificaram que o material moído por 20 horas ainda precisava ser ativado termicamente antes que pudesse absorver hidrogênio pela primeira vez à temperatura ambiente. Já ativo, o material moído absorveu hidrogênio (até 1,3\% em massa de $\mathrm{H}_{2}$ ) sob os platôs de pressão de $0,5 \mathrm{MPa} e$ $25 \mathrm{MPa}$, que corresponderiam, respectivamente, à formação dos hidretos $\beta \mathrm{TiFeH}$ e $\gamma \mathrm{TiFeH}_{2}$ (FIGURA 11b). Contudo, o valor encontrado para o segundo platô (25MPa) se encontra em total desacordo com o esperado pela literatura (1MPa para o TiFe fundido), uma questão a ser investigada. Assim como Abe e Kuji (2007), os autores também verificaram que nem todo hidrogênio absorvido pelo composto podia ser dessorvido após a primeira ciclagem $(0,7 \%$ em massa de $\mathrm{H}_{2}$ ). 

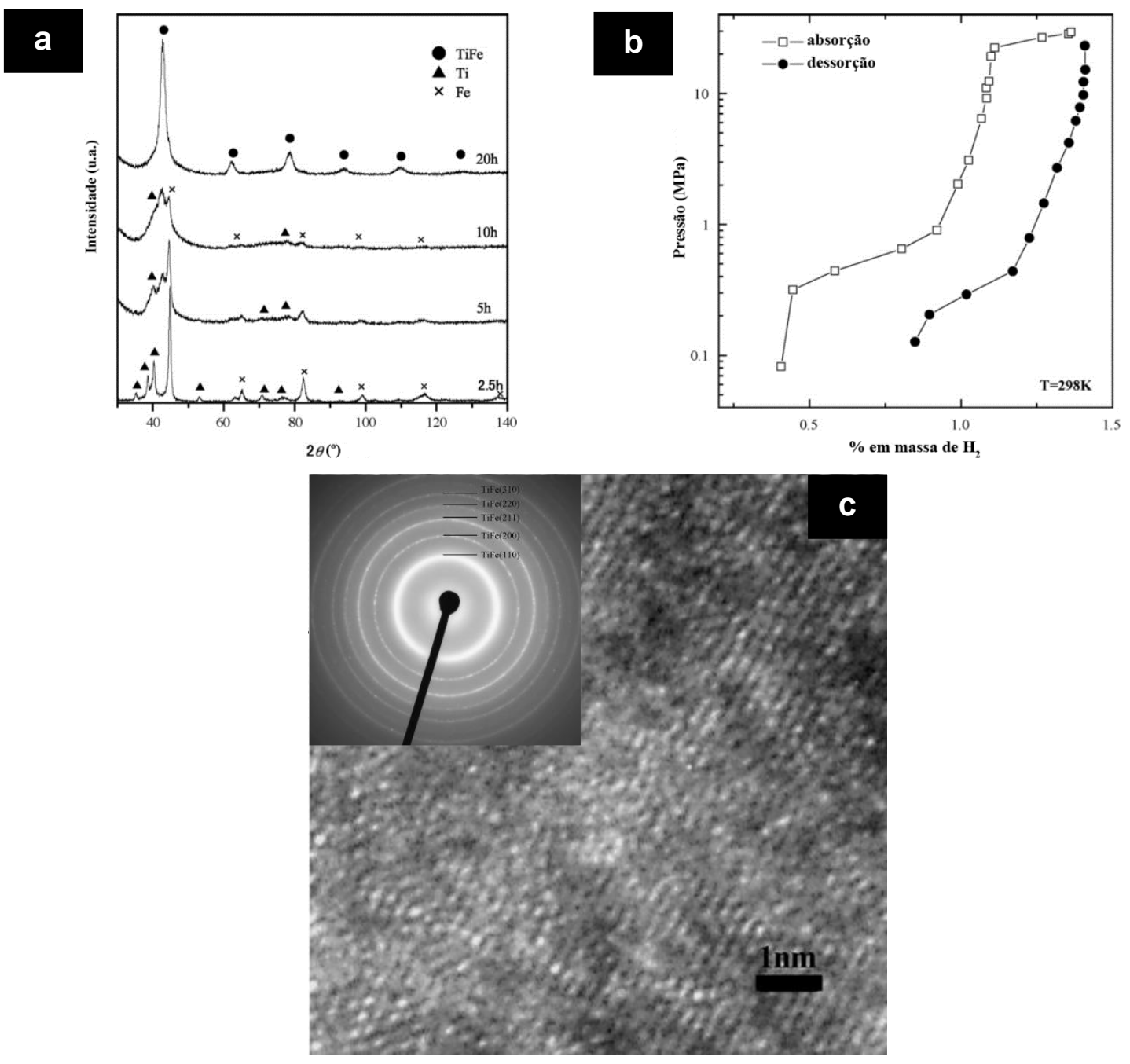

FIGURA 11 - (a) Difratogramas de raios $X(D R X)$ dos materiais moídos por diferentes tempos; (b) Curvas PCTs a temperatura constante de $298 \mathrm{~K}$ para o TiFe elaborado mecanicamente após 20 horas de moagem; (c) Micrografia de elétrons transmitidos (MET) do TiFe elaborado mecanicamente após 20 horas de moagem, além do detalhe do padrão de difração de elétrons da fase TiFe [2] (adaptada).

$\mathrm{Na}$ mesma linha de trabalho, Haraki et al. (2008) confirmaram a elaboração mecânica do composto TiFe após 90 horas de moagem. Também foi constatada uma crescente amorfização do material moído com o aumento do tempo de moagem (de 5 até 100h). Segundo os autores, o material moído por 90 horas apresentava uma mistura de fases amorfa e TiFe nanocristalina (entre 5 e 10nm), ainda com um leve traço de Ti livre, um indicativo de que composição química do material moído poderia conter um excesso de Ti. Além disso, foi observado que diferentes áreas das partículas do pó moído (mais superficial ou mais interna) podiam contribuir de diferentes formas na mistura 
amorfa e nanocristalina (maior densidade da fase nanocristalina no interior das partículas), resultados confirmados por MET. O material moído por 90 horas apresentou agregados levemente arredondados entre 5 e $10 \mu \mathrm{m}$.

Haraki et al. (2008) observaram ainda que o material moído por 90 horas já absorvia hidrogênio $(99,99999 \%$ de pureza) à temperatura ambiente, sem qualquer tipo de ativação térmica, sob o platô de pressão de $0,5 \mathrm{MPa}$, atingindo sua capacidade máxima de armazenamento $(\mathrm{H}: \mathrm{TiFe}=1,3)$ a aproximadamente $5 \mathrm{MPa}$. Além disso, quando exposto diretamente a pressão de $0,5 \mathrm{MPa}$ de hidrogênio à temperatura ambiente, o material moído apresentava uma elevada taxa inicial de absorção, atingindo sua capacidade máxima de armazenamento ( $\mathrm{H}: \mathrm{TiFe} 0,9$, coerente com o esperado para a fase $\beta \mathrm{TiFeH}$ ) em apenas $3000 \mathrm{~s}$ (50min.). Os autores também fazem referência à dificuldade observada por Hotta et al. (2007) na formação da fase $\gamma \mathrm{TiFeH}_{2}$. Segundo estes, tal fenômeno esta diretamente ligado ao aumento da densidade de defeitos cristalinos introduzidos pelo processo de moagem, que resultaria em uma maior solubilidade de hidrogênio na fase $\beta \mathrm{TiFeH}$, e por consequência no atraso da formação da fase $\gamma \mathrm{TiFeH}_{2}$. Ainda segundo os autores, tal fenômeno é típico de materiais moídos com alta energia, e também pode ser observado na transição da fase $\alpha$ para a fase $\beta$ TiFeH.

Zadorozhnyy et al. (2011) também confirmaram a elaboração mecânica do composto TiFe após 1 hora de moagem utilizando diferentes velocidades de rotação do prato do moinho (620 e 840rpm). Nos materiais moídos com maior rotação, foi relatada uma diminuição da fase amorfa em relação à fase nanocristalina TiFe ( $\leq 5 \%$ em massa de fase amorfa após $2 \mathrm{~h}$ de moagem com 840 rpm). A composição química da fase TiFe também parece ter sido menos afetada quando foi empregada uma maior rotação, a julgar pela menor discrepância entre os parâmetros de rede do TiFe moído e do material padrão (TiFe estequiométrico), algo que pode ser verificado na FIGURA 12a. Tais discrepâncias, observadas especialmente nas moagens com menor rotação (desvio nos parâmetros de rede de até $0,81 \%$ em relação ao padrão), indicam que a fase TiFe está supersaturada de Ti (excesso de Ti em solução sólida no TiFe), fenômeno oriundo, segundo os próprios autores, de uma heterogeneidade local na dispersão das fases Ti e Fe (regiões das partículas 
dos pós moídos ligeiramente mais ricas em Ti). Já o tamanho médio de cristalito da fase TiFe (obtido pelo ajuste das funções de Cauchy aos padrões de DRX dos pós moídos), independente da rotação empregada, permaneceu praticamente inalterado com o aumento do tempo de moagem (entre 8 e $10 \mathrm{~nm}$ ), indicando que estas estruturas já haviam sido reduzidas quase ao seu limite ainda na primeira hora de moagem.

Zadorozhnyy et al. (2011) estudaram ainda, por calorimetria exploratória diferencial (DSC) e DRX, as transformações estruturais e de fase induzidas pela temperatura nos materiais moídos por 2 horas com ambas as rotações (620 e 840rpm). Nas transformações ocorridas em menores temperaturas, entre 573 e $643 \mathrm{~K}\left(300\right.$ e $\left.370^{\circ} \mathrm{C}\right)$, primeiros picos exotérmicos dos termogramas apresentados na FIGURA 12b, não foi observada significativa variação na composição de fases (amorfa e nanocristalina), somente uma diminuição dos valores do parâmetro de rede $(0,2972 \mathrm{~nm}$, redução de $\sim 0,2 \%$ em relação ao material moído por $2 \mathrm{~h}$ com $840 \mathrm{rpm})$ e da microdeformação $(0,357 \%$, redução de $\sim 36,5 \%$ em relação ao mesmo material). Já em maiores temperaturas, entre 736 e $816 \mathrm{~K}$ (463 e $\left.543^{\circ} \mathrm{C}\right)$, segundos picos exotérmicos dos termogramas apresentados na FIGURA 12b, houve recristalização da fase amorfa, acompanhada de uma maior diminuição dos valores do parâmetro de rede $(0,2969 \mathrm{~nm}$ para o material moído por $2 \mathrm{~h}$ com $840 \mathrm{rpm})$ e da microdeformação $(0,175 \%$ para o mesmo material), além de um aumento dos valores do tamanho médio de cristalito (12nm para o mesmo material). Feitos estes estudos, os autores escolheram então o material moído por 2 horas com 840rpm para os experimentos com hidrogênio, por este apresentar maior estabilidade da fase TiFe, além de um parâmetro de rede mais próximo ao do composto estequiométrico $(0,2969 \mathrm{~nm})$.

Após as análises, Zadorozhnyy et al. (2011) verificaram que o material selecionado ainda precisava ser ativado termicamente antes que pudesse absorver hidrogênio $(99,9999 \%$ de pureza) pela primeira vez à temperatura ambiente. Quando ativado, o material moído absorveu e dessorveu hidrogênio sob os respectivos platôs de 1,6MPa e 0,6MPa, sendo sua capacidade máxima de armazenagem (1,4\% em massa de $\left.\mathrm{H}_{2}\right)$ atingida a pressão de 40MPa. Assim como Hotta et al. (2007) e Haraki et al. (2008), os autores também constataram 
dificuldade na formação da fase $\gamma \mathrm{TiFeH}_{2}$. Contudo, a formação desta fase não foi confirmada mesmo após 40MPa.

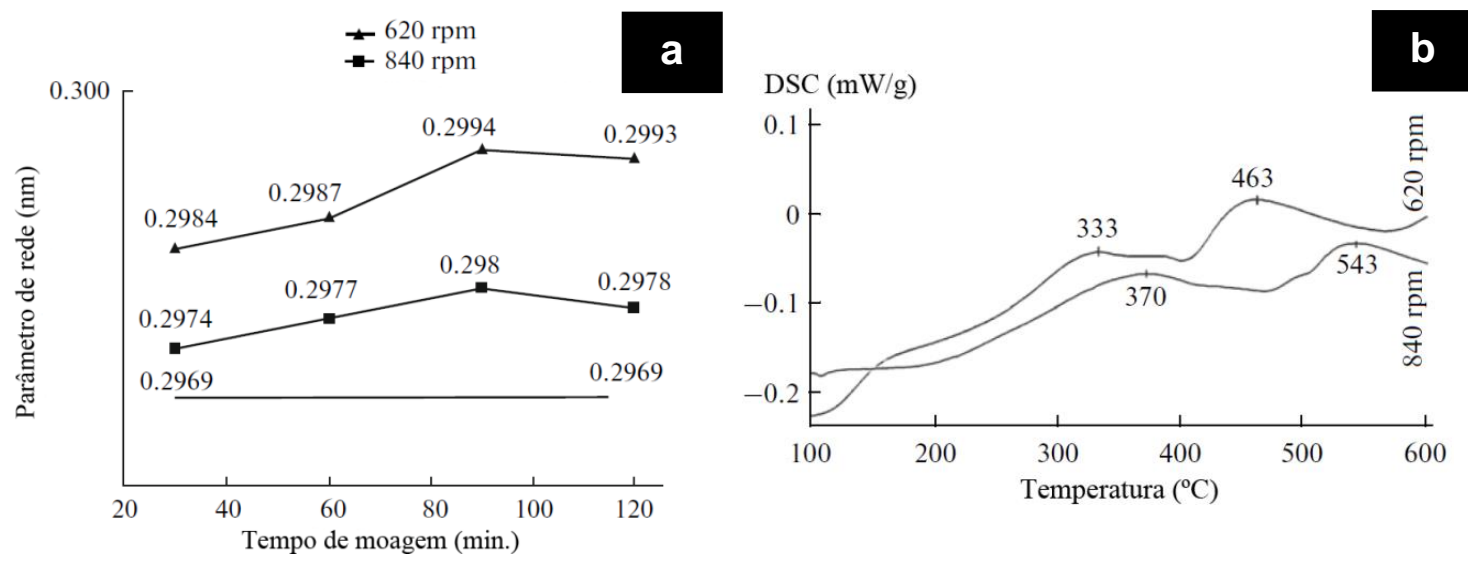

FIGURA 12 - (a) Variação do parâmetro de rede para as diferentes condições de moagem; (b) Termogramas (DSC) dos materiais moídos por 120 minutos com baixa rotação (620rpm) e alta rotação (840rpm) [5] (adaptada).

Os resultados expostos pelos diversos autores mostram claramente que o composto intermetálico TiFe nanoestruturado (entre 5 e 10nm em média), já com excelentes propriedades para absorver hidrogênio, pode ser obtido pela rota de elaboração mecânica (EM). Entretanto, muitos destes autores relataram que o composto TiFe, já ativado pela moagem [6], ainda precisava ser reativado termicamente para que pudesse absorver hidrogênio à temperatura ambiente [2, 5, 8]. Nestes casos, a formação de uma camada impermeável ao hidrogênio, devido à oxidação superficial, seria a principal responsável pela necessidade de reativação. Boas revisões sobre as causas da desativação do composto exposto ao oxigênio podem ser encontradas na literatura [66]. Também foram relatados casos em que o composto moído não precisou ser reativado após as moagens [3, 4]. Nestes, algum outro tipo de mecanismo, provavelmente ligado a desproporção da mistura dos pós de Ti e Fe (com um excesso de Ti), ou mesmo da fase TiFe, impediu essa desativação, observação esta feita com base nas medidas da composição química e do parâmetro de rede apresentados pelos diversos autores. Há que se dizer ainda, que nem todos os autores informaram a pureza do hidrogênio utilizado nas hidretações (pequenas quantidades de contaminantes, como $\mathrm{O}_{2}, \mathrm{CO}$ e $\mathrm{H}_{2} \mathrm{O}$, podem desativar o composto TiFe), em prejuízo da análise comparativa. 
A dificuldade na formação da fase $\gamma \mathrm{TiFeH}_{2}$ foi outra observação comum entre os diferentes autores [2-5]. De fato, poucos autores relataram a formação desta fase, e em platôs não menores que 25MPa de hidrogênio. Tal fenômeno foi associado a um aumento da solubilidade de hidrogênio na fase $\beta \mathrm{TiFeH}$, que resultou no atraso da formação da fase $\gamma \mathrm{TiFeH}_{2}$. Outra questão abordada foi a perda da capacidade reversível de hidrogênio no composto TiFe, onde diversos autores relataram que parte do hidrogênio absorvido não podia ser revertida novamente em hidrogênio molecular, algo que foi atribuído principalmente a presença de fase amorfa e de defeitos cristalinos introduzidos pela própria moagem [2, 4].

Com relação à morfologia das partículas moídas, todos os autores relataram a formação de agregados de aparência arredondada, da ordem de poucos $\mu \mathrm{m}$ (entre 5 e $10 \mu \mathrm{m}$ ). Já com relação ao rendimento do processo, poucos autores relataram abertamente o fenômeno da aderência dos pós de Ti e Fe ao ferramental de moagem (somente Abe e Kuji (2007) dos autores selecionados nesta rota), tão pouco foi proposta alguma alternativa para contornar esse problema. Entretanto, existem fortes indícios de que este é um problema recorrente nas moagens do sistema Ti-Fe, uma questão intrigante.

\subsubsection{Rota de moagem mecânica (MM)}

Na rota de moagem mecânica do composto TiFe, também em uma linha do tempo que se estende a partir da década de 90 , diversos autores estudaram a influência do tempo e da atmosfera de moagem nas propriedades de armazenagem de hidrogênio [2-8].

Zaluski et al. (1993) contribuíram positivamente nesta rota destacando a importância do controle da atmosfera na moagem mecânica do TiFe obtido previamente por fusão a arco. Os autores verificaram que a moagem do composto por 20 horas, sob atmosfera de argônio purificado com menos de 3\% at. de oxigênio, resultou na formação da fase TiFe nanocristalina, assim como em um aumento significativo da fase amorfa. Já a moagem sob atmosfera de argônio com mais de $10 \%$ at. de oxigênio resultou em uma oxidação preferencial do $\mathrm{Ti}$ e na decomposição do composto TiFe em TiO e Fe, com $5.1 \%$ at. de oxigênio dissolvido no pó moído. O material moído por 20 horas 
apresentou agregado de partículas muito finas (entre 1 e $5 \mu \mathrm{m}$ ) soldadas a frio durante a moagem. Também foi relatada a necessidade de reativar o material moído antes que o hidrogênio pudesse ser absorvido pela primeira vez à temperatura ambiente, resultado que corrobora a ideia de que o material moído tem sua reatividade aumentada, e que mesmo pequenas quantidades de oxigênio podem desativá-lo.

Aoyagi et al. (1995) moeram o composto TiFe (0,5 até 24h) já previamente fundido a arco. Os autores verificaram uma diminuição no tamanho de partícula com o aumento do tempo de moagem (16 $\mu \mathrm{m}$ após $24 \mathrm{~h}$ de moagem). Foi observado que os materiais moídos e expostos a $2 \mathrm{MPa}$ de hidrogênio já podiam absorve-lo à temperatura ambiente, sem necessidade de ativação térmica (o material moído foi hidretado no próprio recipiente de moagem), como mostrado a FIGURA 13a. Contudo, também foi observado um aumento da reatividade com oxigênio, o que resultou na desativação do material após exposição a uma atmosfera não controlada (ao ar). O material moído não absorveu hidrogênio após ser exposto ao ar por aproximadamente 3 minutos (FIGURA 13b). Também foi observado que a capacidade máxima de armazenamento de hidrogênio, bem como a sua taxa de absorção, aumentavam com o tempo de moagem (FIGURA 13a). A capacidade máxima de armazenamento de hidrogênio $(\mathrm{H}: \mathrm{TiFe}=0,75)$ para o maior tempo de moagem (24h) foi atingida após 1000s ( 17min.).

A ideia de um material já ativo in situ apresentada por Aoyagi et al. (1995) corrobora as observações feitas por Novakova et al. (2000), deixando claro que o TiFe é de fato ativado ainda durante a moagem. Neste caso, segundo os próprios autores, a desativação ocorreria após as moagens, quando o composto moído é exposto a uma atmosfera renovada, ainda que controlada (caso típico do carregamento do reator para os experimentos com hidrogênio). Tais observações ajudam a explicar em parte a desativação já relatada por diversos autores. 

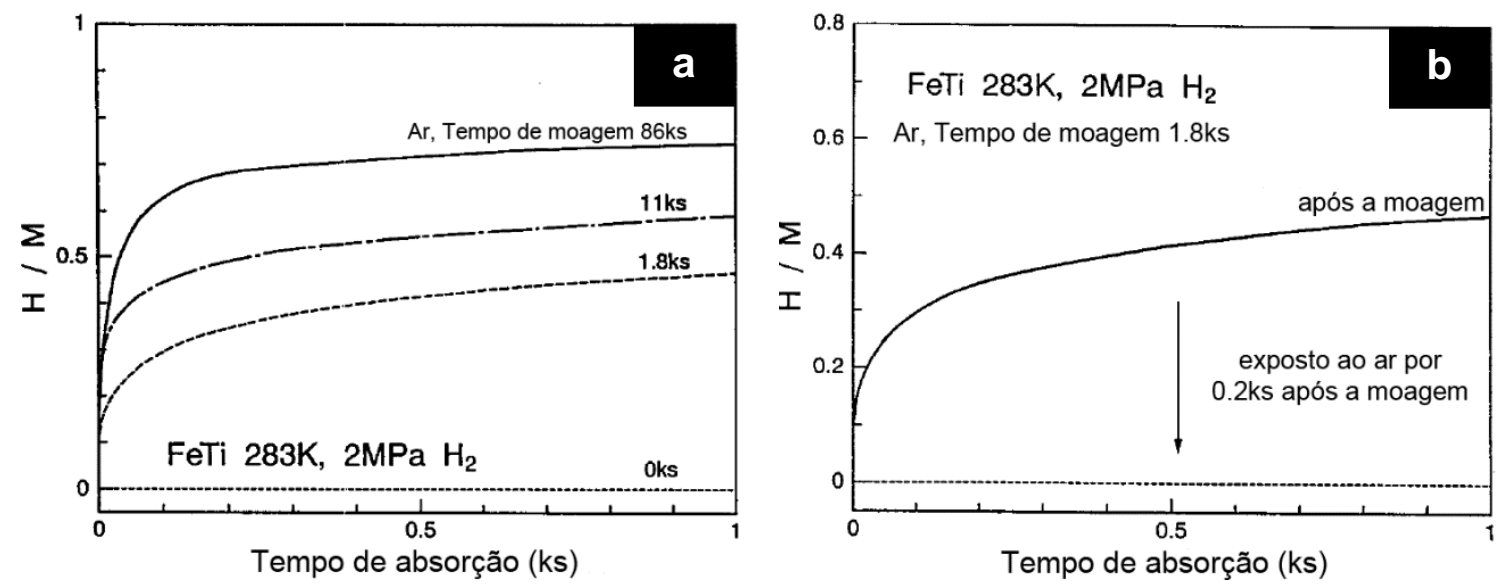

FIGURA 13 - (a) Curvas de absorção de hidrogênio a temperatura constante de $283 \mathrm{~K}$ e pressão de $2 \mathrm{MPa}$ para o TiFe moído por diferentes tempos em atmosfera de argônio; (b) Curvas de absorção de hidrogênio a temperatura constante de $283 \mathrm{~K}$ e pressão de $2 \mathrm{MPa}$ para o TiFe moído por 30 minutos em atmosfera de argônio, e após a exposição a atmosfera não controlada [67].

Chiang et al. (2000) também estudaram a influência da atmosfera de hidrogênio na moagem mecânica do TiFe (moagem reativa). Os autores verificaram que os materiais moídos (entre 1 e 24h) sob atmosfera de hidrogênio podiam absorvê-lo ainda durante as moagens. Além disso, foi observado um crescente aumento da capacidade de armazenamento de hidrogênio ao longo das moagens, o que resultou na capacidade máxima de armazenamento $(\mathrm{H}: \mathrm{TiFe}=0,88)$ após 24 horas de moagem sob a pressão final de 0,14MPa. Contudo, também se constatou uma crescente decomposição do hidreto $\mathrm{TiFeH}_{\mathrm{x}}\left(\mathrm{em} \mathrm{TiH}_{1,924}\right.$ e $\mathrm{Fe}$ ) com o aumento do tempo de moagem, resultado atribuído à saturação da fase hidreto $\left(\mathrm{TiFeH}_{\mathrm{x}}\right)$.

Os resultados apresentados por Chiang et al. (2000) são muito interessantes e vão ao encontro das ideias de Aoyagi et al. (1995) e Novakova et al. (2000) de um material já ativado durante as moagens. Entretanto, assim como Novakova et al. (2000) já haviam observado, o crescente grau de decomposição do $\mathrm{TiFeH}_{\mathrm{x}}$ resultava na formação de segundas fases durante a moagem, o que pode limitar muito a obtenção majoritária da fase TiFe nestes casos.

Em complementação ao seu trabalho, Abe e Kuji (2007) tentaram contornar as dificuldades apresentadas nas moagens por maiores tempos (10 e 40h) adotando a rota de moagem mecânica (por $5 \mathrm{~h}$ ) dos pós elementares (Ti e Fe), seguida de tratamento térmico $(673,773$ ou $873 \mathrm{~K}$ por $3 \mathrm{~h})$ para completar a 
síntese do composto TiFe (FIGURA 14a). Tal rota resultou de fato em uma menor contaminação dos pós $(0,4 \%$ at. de $\mathrm{Cr}$ ), melhores rendimentos (acima de $85 \%$ ), uma maior quantidade de hidrogênio que podia ser dessorvido após a primeira ciclagem (melhor reversibilidade de hidrogênio), além de um aumento na capacidade máxima de armazenamento de hidrogênio em relação aos materiais moídos por 10 e 40 horas, $\mathrm{H}: \mathrm{Ti}+\mathrm{Fe}=0,64\left(1,25 \%\right.$ em massa de $\left.\mathrm{H}_{2}\right)$ sob a pressão de 5MPa (FIGURA 14b). Há que se ressaltar, porém, que não houve a formação majoritária da fase TiFe no produto final (grandes quantidades de $\mathrm{Ti}$ e $\mathrm{Fe}$ livres ainda foram observadas), o que pode ser justificado, em boa parte, pelo baixo tempo de moagem do material (5h). Neste sentido, ainda se busca uma rota de processo que seja capaz de aliar os benefícios citados pelos autores com a síntese majoritária da fase TiFe.
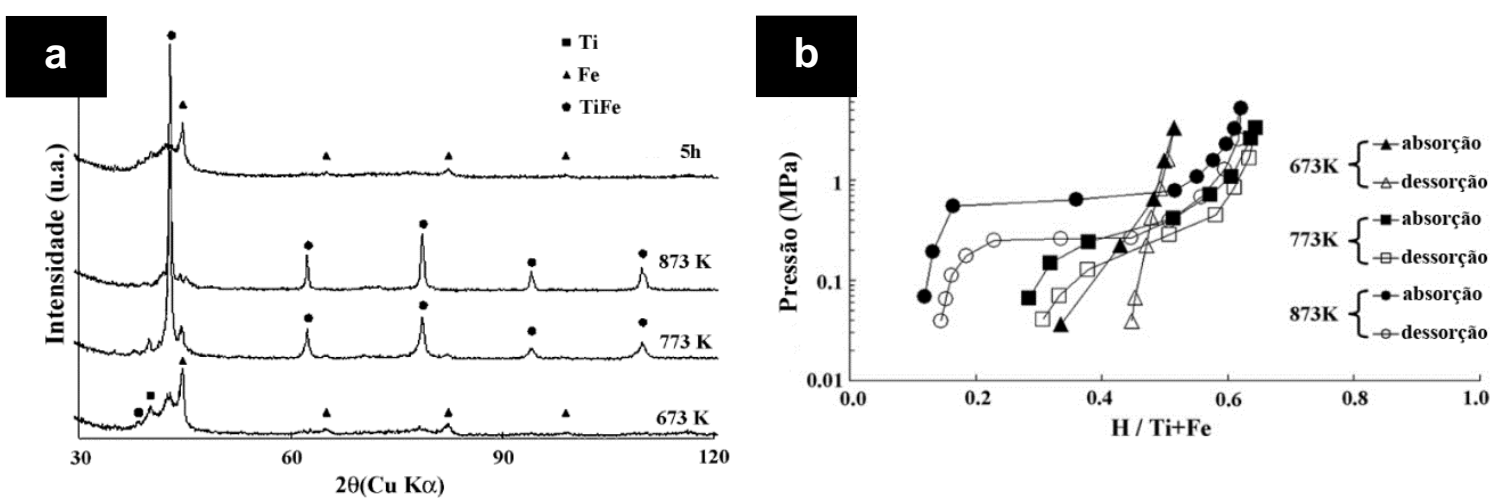

FIGURA 14 - (a) Difratogramas de raios X (DRX) do material moído e tratado termicamente a diferentes temperaturas; (b) Curvas PCTs a temperatura constante de $303 \mathrm{~K}$ para o TiFe sintetizado após os tratamentos térmicos a diferentes temperaturas [3].

Também na rota de moagem mecânica, Haraki et al. (2008) moeram o composto TiFe $(0,25$ até $5 \mathrm{~h})$ previamente fundido por indução. Os autores observaram um crescente alargamento do perfil dos picos de difração de raios $X$ com o aumento do tempo de moagem, resultante da amorfização. Ainda segundo Haraki et al. (2008) o material moído por 2 horas apresentava uma mistura de fases amorfa e TiFe (poli- e nanocristalina, entre 5 e 10nm), assim como no TiFe elaborado mecanicamente no mesmo trabalho. Contudo, a contribuição da fase amorfa neste caso foi significativamente menor, ficando quase que exclusivamente concentrada na superfície das partículas dos pós moídos (alta densidade da fase policristalina no interior das partículas). 0 
material moído por 2 horas apresentava ainda agregados de partículas arredondados de aproximadamente $2 \mu \mathrm{m}$, resultado que se manteve praticamente inalterado com o aumento do tempo de moagem (de 2 até $3 \mathrm{~h}$ ). A questão da composição química dos pós moídos não foi abordada pelo autor, tão pouco foram apresentados os respectivos valores para o parâmetro de rede da fase TiFe.

Após a moagem, Haraki et al. (2008) observaram que o material fundido e moído por 2 horas podia absorver hidrogênio (99,99999\% de pureza) à temperatura ambiente, sem ativação térmica, sob o platô de pressão de aproximadamente $0,7 \mathrm{MPa}$, correspondente à formação do hidreto $\beta \mathrm{TiFeH}$, atingindo sua capacidade máxima de armazenamento ( $\mathrm{H}: \mathrm{TiFe} \mathrm{1,28)} \mathrm{a}$ aproximadamente $1,5 \mathrm{MPa}$. Também foi observado um segundo platô a aproximadamente $3 \mathrm{MPa}$, correspondente a formação do hidreto $\gamma \mathrm{TiFeH}_{2}$, que atingiu sua capacidade máxima de armazenamento $(\mathrm{H}: \mathrm{TiFe}=1,7)$ a $5 \mathrm{MPa}$. Já quando exposto diretamente a pressão de $0,5 \mathrm{MPa}$ de hidrogênio à temperatura ambiente, o material moído apresentou uma elevada taxa inicial de absorção, atingindo sua capacidade máxima de armazenamento ( $\mathrm{H}: \mathrm{TiFe} 1,5)$ em apenas 3000 s (50min.). Tais resultados, se comparados com aqueles obtidos pelos mesmos autores na rota de elaboração mecânica, apresentam melhoras significativas na cinética de absorção e dessorção de hidrogênio, bem como na capacidade de armazenamento reversível de hidrogênio em platôs de pressão relativamente baixos $(<10 \mathrm{MPa})$.

Ainda na rota de moagem mecânica, Emami et al. (2015) moeram o composto TiFe (12 até 36h) já previamente obtido por fusão. Foi observada uma crescente amorfização do material moído ao logo do tempo, processo que parece ter se estabilizado após 36 horas de moagem. Segundo os autores, após 36 horas de moagem o material apresentava majoritariamente a fase TiFe nanocristalina $(\sim 7 \mathrm{~nm})$, verificada por MET. Tal resultado parece ser consistente com o tamanho médio de cristalito obtido do refinamento dos padrões de DRX dos materiais moídos $(\sim 11 \mathrm{~nm})$, onde se utilizou o método de Rietveld associado à função de perfil pseudo-voigt TCH ("Thompson-Cox-Hastings"). $\mathrm{O}$ material assim moído apresentava ainda agregados de pequenas partículas arredondadas entre $100 \mathrm{~nm}$ e $5 \mu \mathrm{m}$. Os autores reportaram o uso de ACP $(20 \%$ 
em massa de acetona) para controlar a aderência dos pós ao ferramental de moagem, sem mencionar, contudo, os rendimentos do processo. A fase TiFe parecia ser mais rica em Ti, conforme indicado pelo valor medido do parâmetro de rede $(0,298 \mathrm{~nm})$.

Emami et al. (2015) verificaram que o material moído (armazenado por aproximadamente um mês em uma atmosfera não controlada) podia absorver hidrogênio à temperatura ambiente sob 0 platô de pressão de aproximadamente $1 \mathrm{MPa}$, correspondente à formação do primeiro hidreto $\beta \mathrm{TiFeH}$, atingindo sua capacidade máxima de armazenamento $(\sim 1,1 \%$ em massa de $\mathrm{H}_{2}$ ) a aproximadamente $2 \mathrm{MPa}$. Também foi observado um segundo platô a $7 \mathrm{MPa}$, correspondente à formação do segundo hidreto $\gamma \mathrm{TiFeH}_{2}$, que atingiu sua capacidade máxima de armazenamento ( 1,5\% em massa de $\left.\mathrm{H}_{2}\right)$ a aproximadamente $10 \mathrm{MPa}$.

Emami et al. (2015) ressaltam o fato do material moído, mesmo exposto a uma atmosfera não controlada (por aproximadamente um mês), ainda estar ativo, resultado atribuído principalmente à estrutura nanocristalina do composto TiFe $(\sim 7 \mathrm{~nm})$. Realmente, todos os relatos revistos aqui do composto TiFe ativo após as moagens (excluindo os casos in situ, que não mencionaram a presença de nanoestruturas) também mencionaram a presença da fase TiFe nanocristalina [3, 4]. Contudo, a recíproca parece não ser verdadeira, uma vez que, a simples presença de nanoestruturas não garantiu a ativação em diversos outros casos [2, 5, 8]. Nestes casos, a variação da composição química (excesso de Ti) parece ter sido o mecanismo responsável por manter o TiFe ativo após as moagens.

Os resultados expostos pelos diversos autores nesta rota (MM) deixam claro que o composto TiFe moído tem sua reatividade com hidrogênio, assim como com oxigênio, aumentada pela moagem. Realmente, alguns autores relataram a necessidade de reativar (o composto já havia sido ativado durante a própria moagem) o TiFe antes que este pudesse absorver hidrogênio pela primeira vez à temperatura ambiente [8]. Novamente, a formação de uma fina camada de óxido seria a principal responsável pela não absorção de hidrogênio. Também foram relatados casos em que o composto moído não precisou ser reativado após as moagens [3, 4, 61], sendo a desproporção estequiométrica o aparente mecanismo de manutenção desta atividade. A 
observação anterior (da rota de EM) feita com relação à pureza do hidrogênio utilizado pelos autores em seus experimentos se mantém a mesma nesta rota.

A dificuldade na formação da fase $\gamma \mathrm{TiFeH}_{2}$, frequentemente observada na elaboração mecânica, parece ter sido sensivelmente reduzida nesta rota [4, 61]. De fato, os referidos autores relataram a formação dessa fase em platôs de pressões relativamente menores do que as observadas na rota de elaboração mecânica (entre 5 e 7MPa), fenômeno que foi acompanhado por uma menor solubilidade de hidrogênio nas demais fases do processo de hidretação. A perda da capacidade reversível de hidrogênio também foi reduzida nesta rota. Há que se dizer, contudo, que as relatadas melhorias foram sempre acompanhadas de um aumento na pressão dos platôs de formação do primeiro hidreto $(\beta T i F e H)$, uma questão ambígua.

Com relação à morfologia das partículas, assim como na rota de EM, todos os autores relataram a formação de agregados arredondados da ordem de poucos $\mu \mathrm{m}$ após as moagens. Já com relação ao rendimento do processo, poucos foram os autores que relataram algum tipo de aderência dos pós ao ferramental de moagem (somente Emami et al. (2015) dos autores selecionados nesta rota), quando o fizeram, um ACP orgânico (acetona) foi empregado para controlá-la.

\subsubsection{Controle da aderência e atividade do composto TiFe após a moagem}

Como já havia sido abordado anteriormente, os pós metálicos processados por moagem de alta energia podem apresentar de fato uma forte tendência à soldagem mútua e aderência ao ferramental de moagem, fenômeno que pode ser observado na FIGURA 15 [3, 9, 34, 61]. Normalmente, o controle de tal fenômeno é realizado pela adição de ACPs orgânicos as moagens. Entretanto, nas rotas de moagem do sistema Ti-Fe, poucos são os relatos sobre o uso destes agentes controladores [9, 59, 61, 68, 69]. 


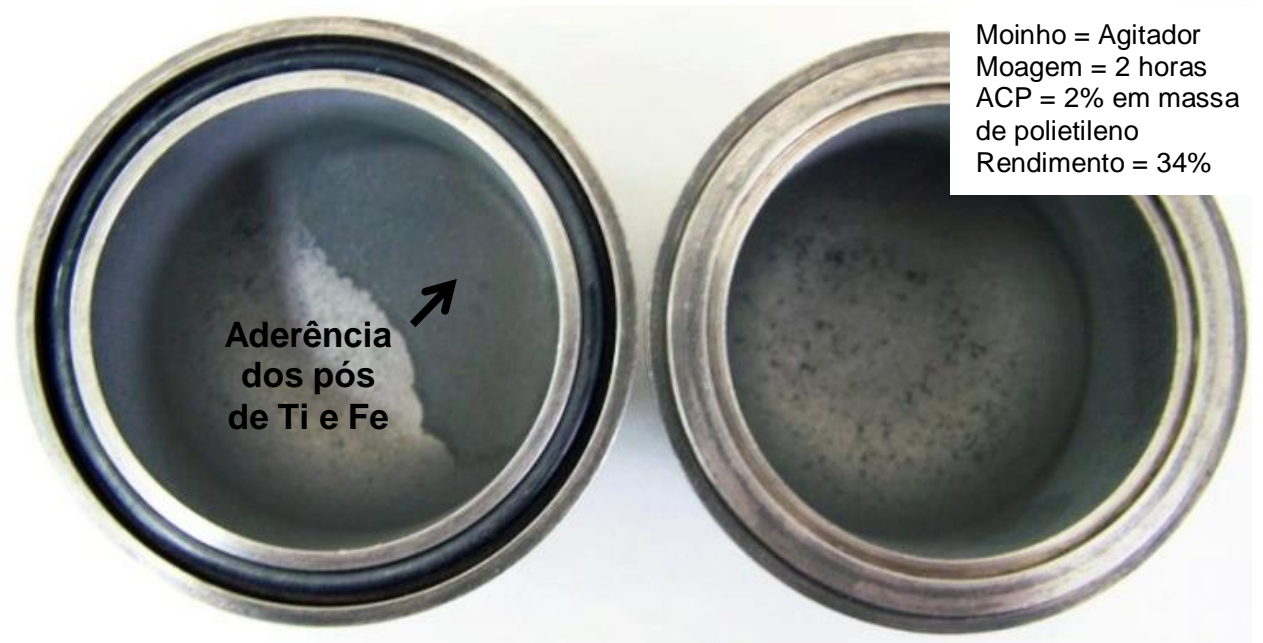

FIGURA 15 - Exemplo de aderência dos pós de Ti e Fe ao recipiente de moagem [9].

Uma boa justificativa para a escassez destes relatos pode estar relacionada ao fato de muitos dos conhecidos ACPs orgânicos apresentarem uma tendência a se decomporem durante a moagem, liberando átomos de carbono, oxigênio e hidrogênio, que ao reagirem com as partículas dos pós moídos podem formar carbetos, óxidos e hidretos [9, 52, 61, 70, 71]. De fato, Arias (1975) já havia constatado que mesmo compostos orgânicos considerados quimicamente inertes (como os alcanos e o benzeno) podiam reagir com as partículas dos pós moídos, sendo a severa deformação plástica, o aumento local de temperatura e a exposição das superfícies das partículas apontadas como as possíveis causadoras deste fenômeno. Outros autores, como Zhang et al. (1999), constataram ainda que a eficiência do ACP é mantida até um determinado estágio da moagem, ocorrendo uma diminuição progressiva desta eficiência com o aumento do tempo de moagem, um claro indício de que os ACPs poderiam estar se decompondo, ou mesmo sendo aprisionados entre as lamelas dos pós moídos.

Já nas rotas do sistema Ti-Fe, autores como Falcão et al. (2010) também já haviam observado uma perda da eficiência de diversos tipos de ACPs (etanol, ácido esteárico, polietileno de baixa densidade, benzeno e ciclohexano) ao longo das moagens dos pós de Ti e Fe, algo que foi associado a uma parcial decomposição dos ACPs durante as moagens, seguida pela reação do carbono com as partículas dos pós moídos de Ti (formando TiC). Emami et al. (2015) também encontraram indícios que o agente orgânico 
(acetona) poderia reagir com os pós moídos de TiFe, constatando no produto final da moagem a presença de elevadas quantidades de carbono e oxigênio (11\% at. de $\mathrm{O}_{2}$ e $8 \%$ at. de $\mathrm{C}$ ), algo que também foi atribuído à parcial decomposição do ACP.

Do exposto pelos diversos autores, fica evidente que os ACPs podem servir como uma grande fonte de contaminantes para os pós metálicos processados por moagem de alta energia. Neste sentido, ainda se procura um ACP "ideal", que possa desempenhar o seu papel durante a moagem, porém, sem contaminar o produto final.

Além do controle da aderência, diversos autores ainda buscam na moagem de alta energia alternativas para obter o composto TiFe ativo. Contudo, como já havia sido observado, o TiFe ativado pela moagem se torna altamente reativo não só com hidrogênio, mas também com oxigênio, fato que muitas vezes demandou a reativação do composto por meio da aplicação de tratamentos térmicos após as moagens [2, 5, 8, 72].

Chu et al. (1991) verificaram que o composto TiFe, elaborado mecanicamente após 25 horas de moagem em um moinho do tipo planetário, não podia absorver hidrogênio à temperatura ambiente, sendo necessária a aplicação de um tratamento térmico, 573K (ou 673K) por 1 hora sob pressão de hidrogênio de $0,7 \mathrm{MPa}$ (ou $1 \mathrm{MPa}$ ), para a sua reativação. As diferentes temperaturas de aquecimento, $573 \mathrm{~K}$ e $673 \mathrm{~K}$, foram utilizadas para avaliar um hipotético efeito dessa variável sobre a ativação térmica do material. Entretanto, os autores não encontraram qualquer relação entre o aumento da temperatura dos tratamentos térmicos e a ativação, uma vez que a capacidade de absorção se manteve inalterada nos dois casos.

Hotta et al. (2007) também verificaram a necessidade de reativar o material moído, e assim como Chu et al. (1991), utilizaram tratamentos térmicos para tal intento. Os autores reativaram o composto moído por 20 horas aplicando cinco ciclos de desgaseificação sob vácuo (a 573K) seguidos de pressurização com hidrogênio (15MPa). Da mesma forma, Zadorozhnyy et al. (2011) reativaram o material moído por 2 horas com 840rpm aplicando ciclos de desgaseificação sob vácuo seguidos de aquecimento (673K) a pressão de $1 \mathrm{MPa}$ de hidrogênio. 
Uma alternativa para a necessidade de reativar o composto TiFe seria tentar aumentar sua tolerância ao oxigênio e, com esta intenção, diversos autores relataram seus esforços [73-75].

Katamian et al. (1983) utilizaram-se da adição de um terceiro elemento à mistura de pós de Ti e Fe para tentar contornar os problemas com a ativação. Para tal, foram adicionadas quantidades de 2 a $5 \%$ at. de TiC em relação à mistura estequiométrica dos pós. Após a fusão os autores obtiveram uma fina dispersão de partículas de TiC na matriz de TiFe. A expectativa dos autores era de que o TiC pudesse facilitar a difusão de hidrogênio para o interior do composto TiFe, sem prejudicar significativamente a sua capacidade de armazenamento, visto que, o TiC também poderia absorver certa quantidade de hidrogênio. E de fato, os autores verificaram que o compósito TiFe-TiC não teve sua capacidade de armazenamento reduzida em relação ao composto TiFe. Contudo, as melhorias esperadas com relação às propriedades de absorção de hidrogênio não foram observadas, e o compósito TiFe-TiC ainda teve que ser termicamente ativado.

Lee e Perng. (1991) e Mizuno e Morozumi (1982) observaram que o composto TiFe com um excesso de $\mathrm{Ti}\left(\mathrm{Ti}_{x} \mathrm{Fe}\right.$ com $\left.1 \leq \mathrm{x} \leq 2\right)$, produzido por fusão a arco, já podia absorver hidrogênio à temperatura ambiente, sem a necessidade de tratamentos térmicos posteriores, resultado atribuído a redução da sensibilidade do material a impurezas gasosas, principalmente ao oxigênio. Neste caso, o excedente de Ti (na forma de $\beta \mathrm{Ti}$ ) estaria funcionando como uma armadilha para o oxigênio, impedindo que este desativasse o TiFe. Além disto, ao ser hidretado, esse excesso de $\mathrm{Ti}$ causaria pequenas fraturas na matriz de $\mathrm{TiFe}$, formando o compósito $\mathrm{TiFe}-\mathrm{TiH}_{2}$, resultando em superfícies novas e reativas aptas à absorver hidrogênio.

Do exposto pelos diferentes autores, fica claro que ainda se procura uma rota capaz de controlar a aderência dos pós de $\mathrm{Ti}$ e $\mathrm{Fe}$ ao ferramental de moagem (aumentar o rendimento do processo) e ao mesmo tempo obter o TiFe de forma majoritária, já apto para absorver hidrogênio pela primeira vez à temperatura ambiente. A busca desta rota e seus desdobramentos constituem os aspectos inéditos do presente trabalho. Para tal fim, se adotou a rota de moagem mecânica de misturas de pós de $\mathrm{TiH}_{2}$ e Fe seguida de tratamentos térmicos para a síntese por reação do composto TiFe. 


\section{MATERIAIS E MÉTODOS}

\subsection{Moagem dos pós de partida $\left(\mathrm{TiH}_{2}\right.$ e $\left.\mathrm{Fe}\right)$}

Foram utilizados como materiais de partida os pós de $\mathrm{TiH}_{2}$ (pó de $\mathrm{Ti}$, 99,7\% de pureza, -325 mesh, lote: 908526-2) e Fe (pó de Fe, 99,9\% de pureza, -325 mesh, lote: 901529), ambos adquiridos da $\mathrm{AEE}^{\circledR}$ ("Atlantic Equipament Engineers"). A hidretação do $\mathrm{Ti}\left(\mathrm{TiH}_{2}\right)$ ocorreu mediante o aquecimento do pó deste material em atmosfera de hidrogênio ( 10bar) até a temperatura de $500^{\circ} \mathrm{C}$ (por $\sim 10 \mathrm{~min}$.). Após a hidretação, amostras destes materiais (pós de $\mathrm{TiH}_{2}$ e $\mathrm{Fe}$ ) foram separadas para caracterização (DRX, EDXRF, DSC e TG) e moagem, algo que que ainda será abordado com maiores detalhes nos itens subsequentes deste trabalho.

As amostras para moagem foram preparadas com uma massa nominal de $30 \mathrm{~g}$ da mistura de pós de $\mathrm{TiH}_{2}$ e $\mathrm{Fe}$, cuja proporção em massa foi estabelecida com base na proporção estequiométrica do composto TiFe (50\% at. de $\mathrm{Ti} \mathrm{e} 50 \%$ at. de $\mathrm{Fe}$ ), ou ainda com um ligeiro excesso de $\mathrm{Ti}$ (56\% at. de $\mathrm{Ti}$ e $44 \%$ at. de $\mathrm{Fe}$ ), valores estes correspondentes aos lotes composicionais $50: 50$ e 56:44, respectivamente. As massas dos pós foram medidas com o auxilio de uma balança digital semianalítica (Ohaus Explorer ${ }^{\circledR}$ Pro; $\sigma= \pm 0,001 \mathrm{~g}$ ).
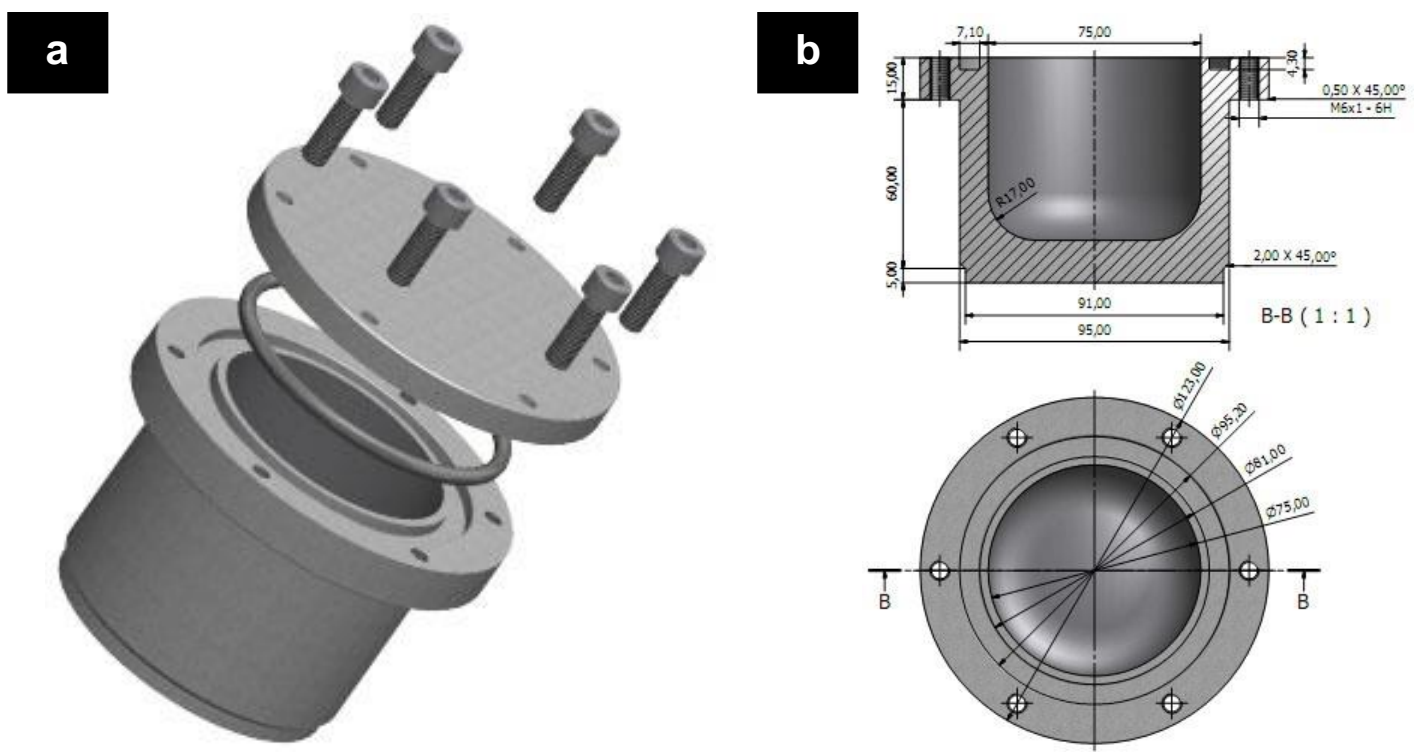

FIGURA 16 - Ilustração esquemática do recipiente utilizado nas moagens: (a) Visão explodida do recipiente; (b) Dimensões do recipiente (em $\mathrm{mm}$ ). 
Após pesados, os pós foram misturados em um recipiente de moagem, que consistia de um copo de aço inoxidável endurecido (ABNT 420, Volume $=275 \mathrm{~cm}^{3}$ ), selado por um anel de viton e com fundo de cantos arredondados (ver FIGURA 16), no qual foram adicionadas 295 bolas de aço cromo-vanádio (ABNT 52100, $\varnothing=8 \mathrm{~mm}$ ), número esse calculado em função da razão nominal entre a massa das bolas e a massa nominal da mistura dos pós de partida, aqui adotada como 20:1. Para evitar a oxidação dos pós metálicos, que poderia se acentuar devido ao aumento da temperatura e da superfície de contato durante a moagem, todos os procedimentos de carregamento foram realizados dentro de uma caixa de luvas com argônio purificado (MBraun ${ }^{\circledR}$ LABstar Glovebox, FIGURA 17a).

Já fechado, o conjunto foi retirado da caixa de luvas e transportado até um moinho do tipo planetário (Pulverisette 5 Fritsch $^{\circledR}$, FIGURA 17b). As moagens foram realizadas sempre com a mesma velocidade de rotação do prato do moinho (300rpm) e variando o tempo de moagem (5, 10, 25 e 40h). Em todas as moagens, com o intuito de evitar um aumento exacerbado da temperatura do ferramental de moagem, foram feitas pausas de 30 minutos a cada 30 minutos de operação do moinho, procedimento já adotado por diversos autores da literatura $[4,36,61]$. Na retomada do ciclo o sentido de rotação do prato do moinho foi sempre invertido.
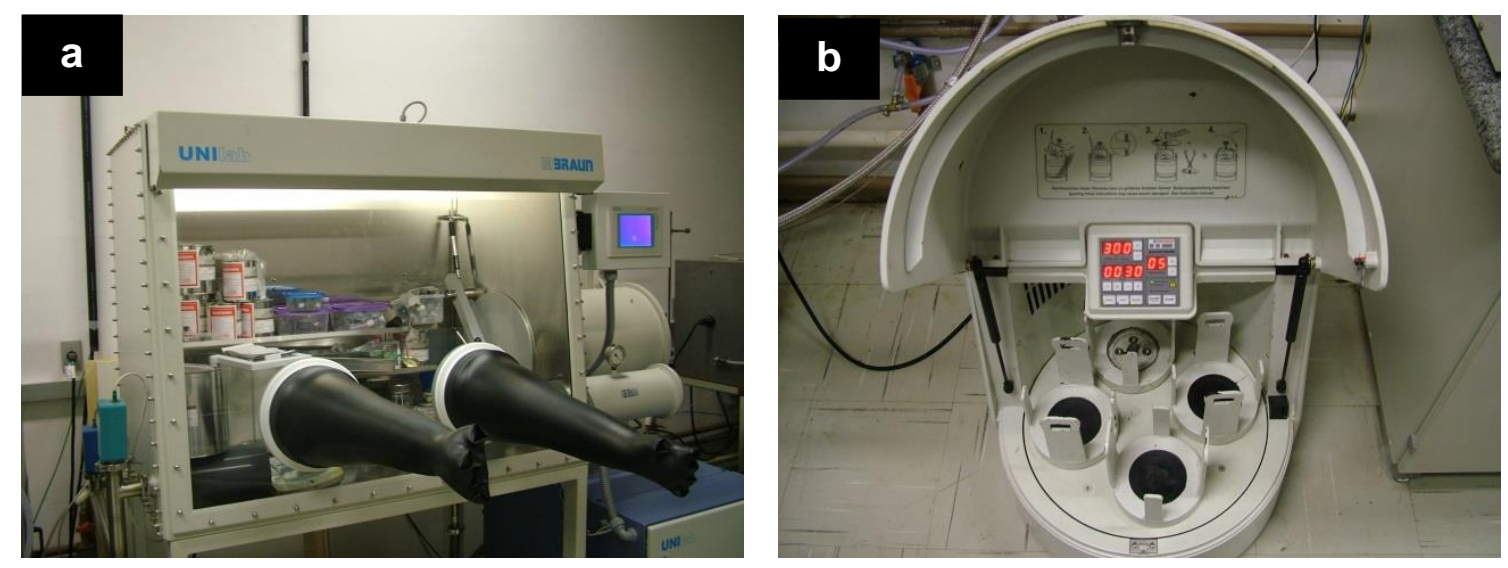

FIGURA 17 - llustração dos equipamentos utilizados nas moagens dos pós: (a) Caixa de luvas com argônio purificado; (b) Moinho do tipo planetário.

Após as moagens, o conjunto foi levado novamente para o interior da caixa de luvas para a operação de descarregamento e controle do rendimento 
(\% da massa retirada do recipiente em relação à massa inicial introduzida). Não foram feitas aberturas intermediarias do recipiente para a retirada de alíquotas das amostras, evitando assim os possíveis efeitos negativos de oxidação relatados por autores como Zaluski et al. (1993). Amostras dos pós moídos foram separadas para posterior caracterização (DRX, EDXRF, MEV, DSC e TG) e investigação de rota de processamento. Um fluxograma com todos os procedimentos utilizados na preparação e caracterização das amostras é apresentado na FIGURA 18.

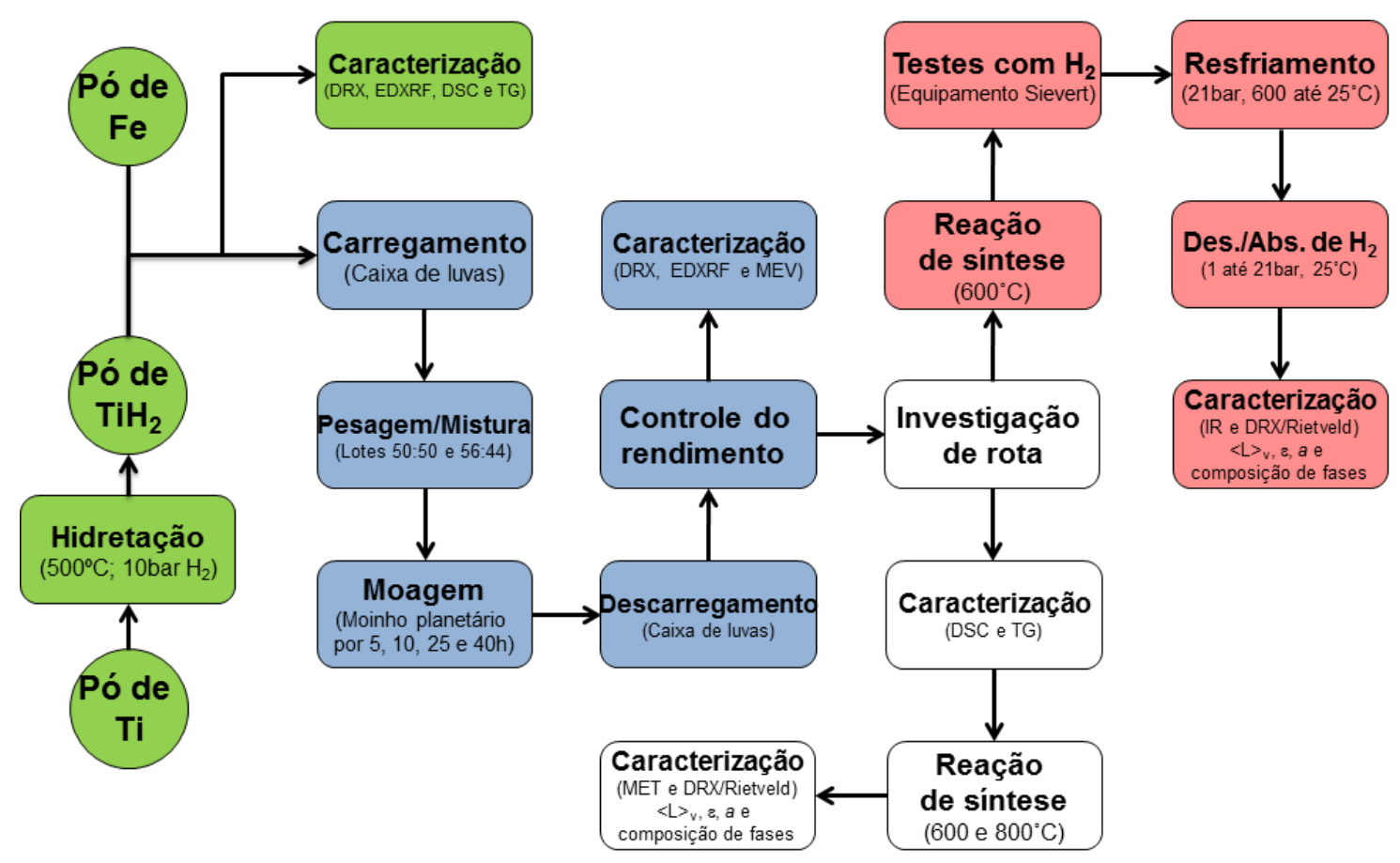

FIGURA 18 - Fluxograma dos procedimentos utilizados na preparação e caracterização das amostras.

\subsubsection{Caracterização dos pós de partida e moídos}

Inicialmente, para avaliar a completa formação do hidreto de $\mathrm{Ti}\left(\mathrm{TiH}_{2}\right)$, utilizado como um dos materiais de partida nas moagens, uma amostra do pó hidretado, cerca de 40mg, foi analisada por calorimetria exploratória diferencial (DSC) e termogravimetria (TG) em um analisador térmico (Setaram ${ }^{\circledR}$ modelo SetSys 1200) com fluxo de argônio e taxa de aquecimento constantes (1L/hora, pureza de $99,999 \%$ e $10^{\circ} \mathrm{C} / \mathrm{min}$.).

Amostras dos pós de partida $\left(\mathrm{TiH}_{2}\right.$ e $\left.\mathrm{Fe}\right)$ também foram analisadas por difração de raios X (DRX; difratômetro Rigaku ${ }^{\circledR}$, modelo Ultima IV; Cu-K $\mathrm{K}_{\alpha}$ ), para 
a confirmação das fases presentes $\left(\alpha \mathrm{TiH}_{2}\right.$ e $\left.\alpha \mathrm{Fe}\right)$. Nestas análises foram realizadas varreduras angulares de $32,5^{\circ}$ a $103,8^{\circ}(2 \theta)$, com passo angular $0,02^{\circ}$ e tempo de contagem por passo de 10 segundos. A identificação das fases presentes nas amostras foi feita mediante a comparação dos picos de difração, que foram obtidos dos padrões de DRX das amostras, com os picos dos padrões de DRX encontrados na base de dados ${ }^{3}$ PDF-2 (do inglês "Powder Diffraction File 2").

Foi avaliada ainda uma possível contaminação inicial dos materiais de partida. Para tal fim, amostras dos pós foram analisadas por fluorescência de raios $X$ por dispersão de energia (EDXRF; espectrômetro Shimadzu ${ }^{\circledR}$, modelo 720; $\left.\mathrm{Rh}-\mathrm{K}_{\alpha}, 15-50 \mathrm{Kv}\right)$, onde utilizaram-se tempos de contagem de 100s.

Após as moagens, a morfologia e o tamanho de agregados das partículas dos pós moídos de ambos os lotes (das composições 50:50 e 56:44) foram caracterizados em um microscópio eletrônico de varredura (MEV; Philips ${ }^{\circledR}$ modelo $\mathrm{X} 30$ ), onde se utilizou o sinal de elétrons secundários. As amostras separadas para este fim foram inicialmente dispersas em um substrato, já previamente aderido a um porta amostras. Já a microestrutura dos agregados foi caracterizada em um microscópio eletrônico de varredura com emissão de campo (MEV-FEG; Jeol ${ }^{\circledR}$ modelo JSM-6701F), onde se utilizou o sinal de elétrons retroespalhados, bem como a energia dispersiva dos raios $X$ (EDS) provenientes de microrregiões das amostras. As amostras separadas para este fim foram inicialmente embutidas em resina de cura a frio em pequenos moldes cilíndricos de cobre. Após o endurecimento da resina, os moldes de cobre foram, por sua vez, embutidos em baquelite (termoplástico). As amostras assim embutidas foram lixadas com SiC de grana 400, 600 e 1000 e polidas com pasta de diamante de grana $6 \mu \mathrm{m}$, $3 \mu \mathrm{m}$ e $1 \mu \mathrm{m}$.

Ainda após as moagens, para avaliar possíveis mudanças estruturais nas fases hidreto $\left(\alpha \mathrm{TiH}_{2}\right)$ e $\alpha \mathrm{Fe}$, ou mesmo a formação de novas fases, as amostras dos pós moídos de ambos os lotes foram analisadas por DRX (no mesmo difratômetro já descrito anteriormente). Nestas análises foram realizadas varreduras angulares de $30^{\circ}$ a $85^{\circ}(2 \theta)$, com passo angular $0,05^{\circ} \mathrm{e}$ tempo de contagem por passo de 10 segundos. Assim como nos caso dos pós de partida, a identificação das fases presentes nas amostras ocorreu mediante 
a comparação dos picos de difração com padrões. Uma estimativa da porcentagem atômica de Ti em solução no $\mathrm{Fe}$ após as moagens foi obtida a partir da lei de Vegard, utilizando o deslocamento do pico (110) da fase Fe das amostras moídas em relação ao pico (110) da solução sólida $\mathrm{Fe}_{9,64} \mathrm{Ti}_{0,36}$.

Também foi avaliada uma possível contaminação das amostras após as moagens, resultante do desgaste do ferramental de moagem, ou mesmo dos próprios pós de partida. Para tal fim, amostras dos materiais moídos (somente da composição 50:50) foram analisados por EDXRF (no mesmo espectrômetro já descrito anteriormente). Nestas análises semiquantitativas foram utilizados tempos de contagem de 100s.

Após a caracterização, para estudar o processo de síntese por reação do composto TiFe, as amostras dos pós moídos (somente da composição 50:50), cerca de 40mg, foram analisadas por DSC e TG em um analisador térmico (o mesmo analisador já descrito anteriormente) com fluxo de argônio e taxa de aquecimento constantes (1L/hora, pureza de $99,999 \%$ e $10^{\circ} \mathrm{C} / \mathrm{min}$.). A análise termogravimétrica foi utilizada para acompanhar o desprendimento de gases (vapor de água e hidrogênio), bem como uma possível oxidação dos materiais moídos ao longo das análises.

${ }^{3}$ Powder Diffraction File (ed. 2003) da International Center for Diffraction Date (ICDD).

\subsection{Reação de síntese do composto TiFe}

Com base nos resultados obtidos nas análises por DSC e TG, as amostras moídas (dos lotes 50:50 e 56:44) foram tratadas termicamente para a síntese por reação do composto TiFe. Os tratamentos térmicos foram realizados em duas temperaturas distintas, 600 e $800^{\circ} \mathrm{C}$ (sem patamar). Para tal, aproximadamente $2 \mathrm{~g}$ das amostras dos pós moídos, cujas massas foram mediadas com o auxilio de uma balança digital semianalítica (Ohaus Explorer ${ }^{\circledR}$ Pro; $\sigma= \pm 0,001 \mathrm{~g}$ ) em atmosfera inerte (argônio purificado), foram depositadas em uma navícula de aço e introduzidas em uma retorta cilíndrica do mesmo material (que será descrita posteriormente de forma mais detalhada). Depois de fechada, a retorta foi conectada a um sistema auxiliar de vácuo (bombas mecânica e turbo molecular Edwards ${ }^{\circledR}$ modelo EXT 70) que mantinha a pressão no seu interior em aproximadamente $10^{-4}$ mbar. As amostras foram 
então aquecidas da temperatura ambiente até as temperaturas préestabelecidas para os tratamentos (600 ou $800^{\circ} \mathrm{C}$, sem patamar), esse aquecimento ocorreu em um forno resistivo tubular (EDG Equipamentos ${ }^{\circledR}$ modelo Edgcon $3 \mathrm{P}$ ) com uma taxa constante de aquecimento de $10^{\circ} \mathrm{C} / \mathrm{min}$. No decorrer dos tratamentos foi observada uma elevação da pressão dentro da retorta, ocasionada pelo desprendimento de gases, principalmente de hidrogênio. Para garantir o completo desprendimento destes gases aguardouse o restabelecimento da pressão de $10^{-4} \mathrm{mbar}(\sim 5 \mathrm{~min}$.). As amostras reagidas, ainda sob vácuo, foram retiradas do forno e resfriadas através de ventilação forçada. Após o resfriamento, com o intuito de verificar as possíveis transformações estruturais e de fase induzidas pela temperatura, as amostras reagidas foram expostas à atmosfera não controlada (ao ar) e separadas para a caracterização (DRX e MET).

\subsubsection{Caracterização dos pós reagidos}

Após as reações, para confirmar a síntese do TiFe, bem como a possível formação de segundas fases, as amostras reagidas (das composições 50:50 e 56:44) foram analisadas por DRX (no mesmo difratômetro já descrito no item anterior). Nestas análises foram realizadas varreduras angulares de $28^{\circ}$ a $97^{\circ}$ (20), com passo angular $0,05^{\circ}$ e tempo de contagem por passo de 10 segundos. A identificação das fases presentes nas amostras seguiu os mesmos procedimentos já descritos anteriormente. Para determinar 0 parâmetro de rede, o tamanho médio de cristalito e a microdeformação da fase $\mathrm{TiFe}$, os padrões de DRX das amostras reagidas foram analisadas pela método de Rietveld de refinamento, utilizando o software Diffrac ${ }^{\text {Plus }}$ Topas 4.2 da Brucker $^{\circledR}$. Boas revisões sobre a aplicação do método podem ser encontradas na literatura pertinente $[76,77]$. Os ajustes dos padrões foram realizados por meio da função pseudo-voigt TCH (“Thompson-Cox-Hastings") modificada, utilizando o modelo double-voigt de Balzar, onde o perfil dos picos é considerado como sendo uma convolução de funções Gaussianas e Lorentzianas [78]. A estrutura da fase TiFe dos materiais reagidos (somente da composição 50:50) também foi avaliada em microscópios eletrônicos de transmissão (MET; Zeiss ${ }^{\circledR}$ modelo EM912 Omega e METAR; Fei ${ }^{\circledR}$ modelo Tecnai $\left.G^{2} F 20\right)$. 


\subsection{Estudo das propriedades de armazenamento de hidrogênio do TiFe}

Para estudar as propriedades de armazenamento de hidrogênio das amostras reagidas foi utilizado um equipamento automatizado do tipo Sievert (de construção própria do LMI), conectado a um forno resistivo tubular e a uma bomba auxiliar de vácuo turbomolecular (FIGURA 19). Tipicamente estes equipamentos apresentam dois modos de operação, estático e dinâmico, onde são medidas com precisão as pequenas variações no volume de hidrogênio, que ocorrem ao longo dos processos de absorção e dessorção deste gás. No modo estático, as medidas são realizadas a partir da equalização das pressões entre um volume de referência e outro contendo a amostra (volume de trabalho), ambos conhecidos. Já no modo dinâmico, as medidas são realizadas por meio de um controlador de fluxo que pressuriza constantemente, com um volume conhecido de hidrogênio, o volume de trabalho [79].
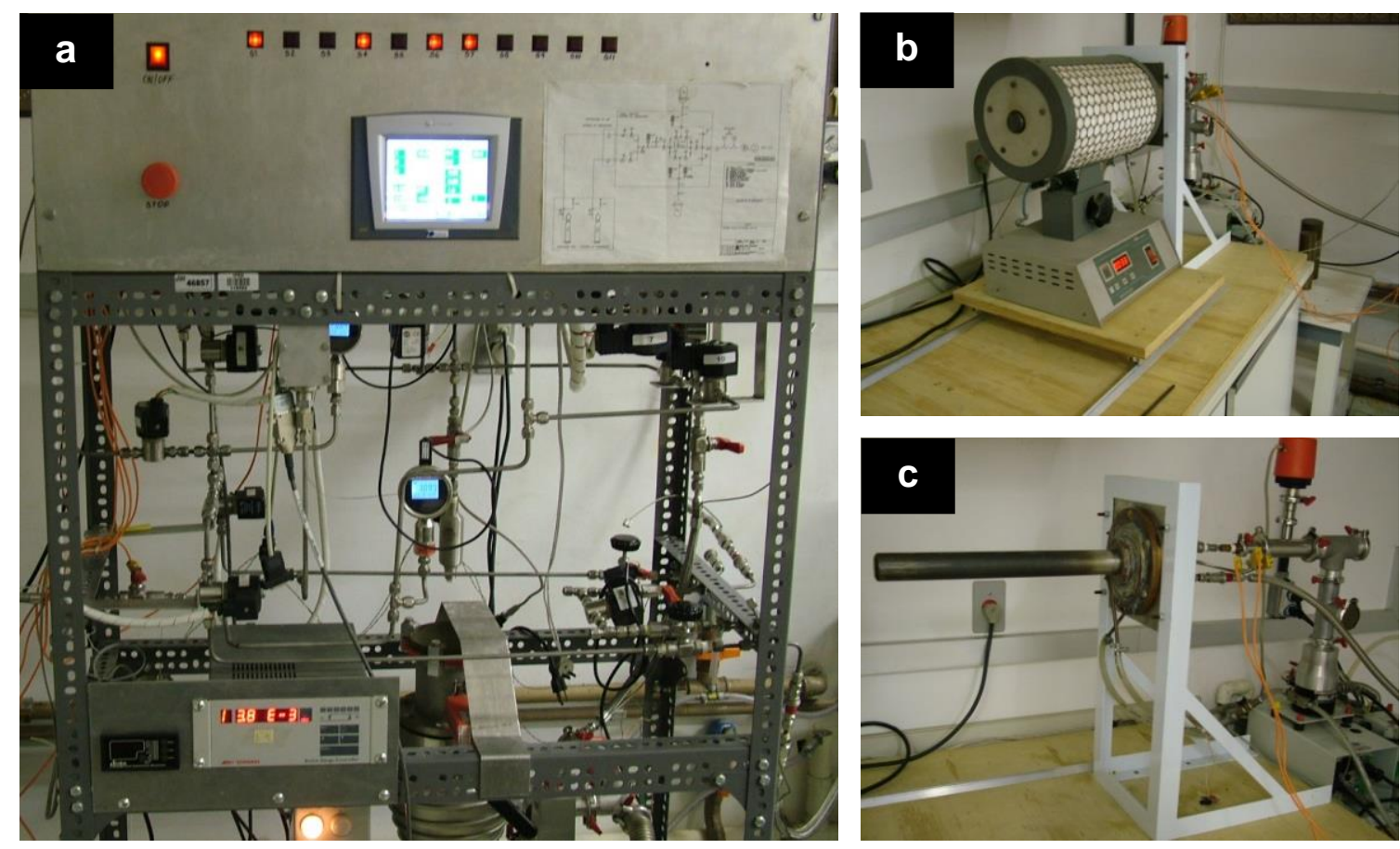

FIGURA 19 - Ilustração do equipamento do tipo Sievert construído pelo LMI (CCTM/IPEN): (a) Painel de controle central do equipamento; (b) Forno resistivo tubular conectado ao reator; (c) Reator conectado a uma bomba auxiliar turbomolecular.

Os dados resultantes destas medidas, em ambos os modos, são frequentemente empregados no estudo da cinética de absorção e dessorção de hidrogênio por materiais metálicos, bem como no levantamento das 
conhecidas curvas PCTs (do inglês "Pressure-Composition and Temperature"), exemplificada na FIGURA 20. Destas curvas, em particular, são extraídas importantes informações, como a capacidade de armazenamento de hidrogênio, representada pela relação atômica hidrogênio-metal $(H: M)$ ou pela porcentagem em massa de hidrogênio no metal $(H)$, os platôs de pressão, os pontos de transição de fases e etc. [45]. Há que se dizer, entretanto, que o modo de operação do sistema pode influenciar sobremaneira a medida de algumas destas propriedades. De fato, já foi observado que as medidas feitas em modo dinâmico podem fornecer curvas PCTs com maiores histereses e com platôs de pressão mais elevados se comparadas com as curvas obtidas no modo estático. Tais resultados podem ser atribuídos, em boa parte, a limitação da troca de calor entre a amostra e o equipamento, uma vez que, as reações exotérmica e endotérmica ocorrem ao longo das medidas, ou mesmo a condição onde a taxa de pressurização do equipamento é maior (ou menor) do que a taxa que o material poderia absorver hidrogênio mantendo uma pressão de equilíbrio (condição de sobrepressão) [80]. Neste sentido, a comparação direta entre os resultados obtidos nos diferentes modos de operação deve ser feita com cautela.

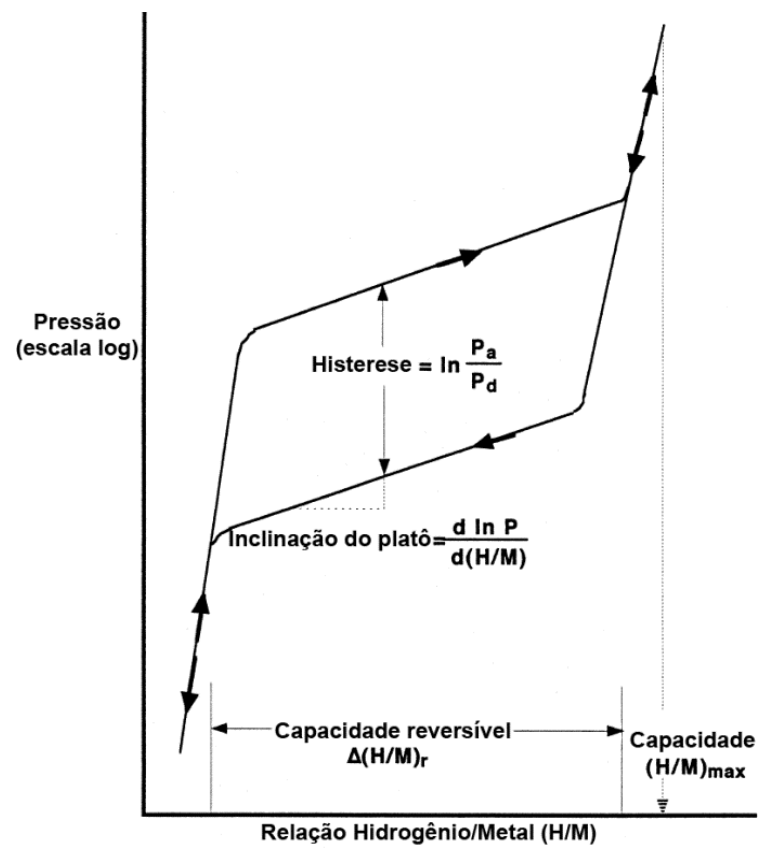

FIGURA 20 - Curva típica da histerese de pressão-composição a temperatura constante [45]. 
No presente trabalho, optou-se pela utilização do equipamento Sievert em modo dinâmico, onde os processos de absorção e dessorção ocorriam no reator do equipamento sob um fluxo constante de hidrogênio $\left(9 \mathrm{~cm}^{3} / \mathrm{min}\right.$. e $99,999 \%$ de pureza). Este reator é composto basicamente de uma retorta cilíndrica de aço dividida em duas partes (interna e externa), seladas por um anel de viton (a mesma retorta utilizada nas reações de síntese do TiFe). A ponteira da parte interna da retorta é feita de cobre (ver FIGURA 21), visando maximizar a troca de calor entre o equipamento e a amostra. Nesta ponteira, a amostra é depositada em uma navícula de aço ligada a termopares do tipo $\mathrm{N}$ (Nicrosil-Nisil). Todas estas partes do reator, bem como as demais restantes do equipamento (ver FIGURA 22), são conectadas a um controlador de fluxo de alta precisão (El-Flow ${ }^{\circledR}$ Bronkhorts; $\sigma=0,5 \% \mathrm{VM} \pm 0,1 \% \mathrm{FS}$ ) e medidores de pressão (Zürich ${ }^{\circledR} ; \sigma=0,5 \% \mathrm{FS}$ ), integrados a um controlador lógico programável (CLP) para a aquisição automática dos dados (com frequência de aquisição de $f=1 / 10$ s). Os dados gerados durante o processo de hidretação, temperatura $(T)$, pressão $(P)$, fluxo $(\phi)$ e tempo(t) foram armazenados na memória interna da CLP para posteriores análises.

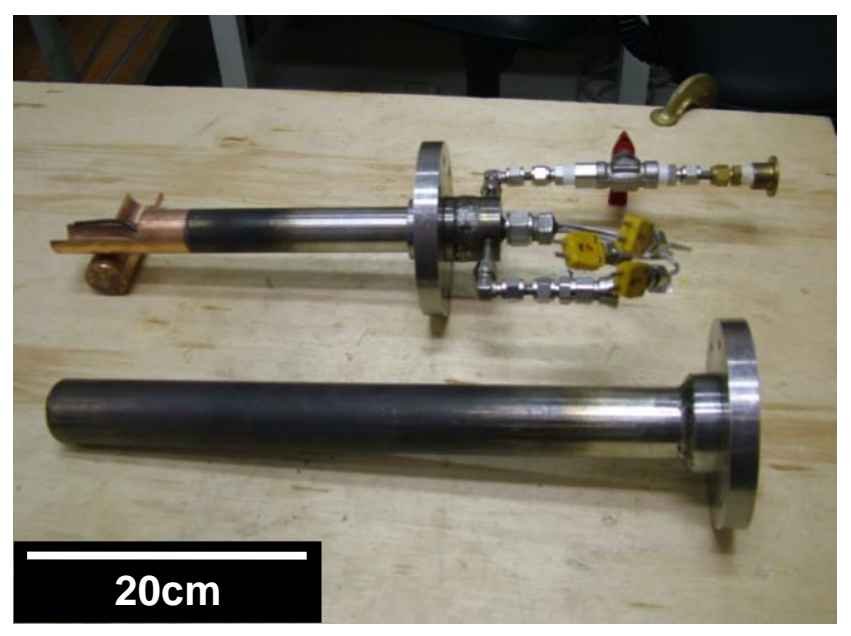

FIGURA 21 - lustração da retorta de aço utilizada nos tratamentos térmicos e no estudo das propriedades de armazenamento de hidrogênio do TiFe.

Para dar início aos experimentos com hidrogênio, aproximadamente $2 \mathrm{~g}$ das amostras moídas por 5, 10, 25 e 40 horas, de ambas as composições, foram tratados termicamente, até $600^{\circ} \mathrm{C}$ sob vácuo dinâmico, para síntese por reação do composto TiFe. $O$ procedimento utilizado nestes tratamentos 
térmicos já foi descrito no item anterior. Após o tratamento térmico, a retorta foi conectada ao equipamento Sievert e pressurizada com hidrogênio (99,999\% de pureza) até aproximadamente 21 bar, porém sem controle de fluxo (o hidrogênio absorvido não foi quantificado). Após atingir a pressão préestabelecida ( 10min.), a retorta foi resfriada através de ventilação forçada até à temperatura ambiente $\left(\sim 25^{\circ} \mathrm{C}\right)$. Depois de constada a primeira absorção de hidrogênio à temperatura ambiente, o equipamento Sievert foi utilizado para estudar de forma mais detalhada as propriedades de armazenamento de hidrogênio das amostras. Para tal fim, o equipamento foi despressurizado e pressurizado (1 até $21 \mathrm{bar}$ ) utilizando-se os fluxos nominais contínuos de $\phi_{\text {ent } / \text { said }}=9 \mathrm{~cm}^{3} / \mathrm{min}$. $\left(0,15 \mathrm{~cm}^{3} / \mathrm{s}\right)$, escolhidos a principio para minimizar os efeitos da sobrepressão relatados por Goodell et al. (1980), completando assim o ciclo de hidretação das amostras. É importante destacar que o termo ciclo de hidretação se refere à sequência de primeira absorção (sem quantificação de hidrogênio) $\rightarrow$ dessorção (quantificação de hidrogênio utilizando a rotina de despressurização do equipamento Sievert) $\rightarrow$ absorção (quantificação de hidrogênio utilizando a rotina de pressurização do equipamento Sievert). Uma descrição mais detalhada da metodologia empregada nas análises dos dados resultantes dos experimentos com hidrogênio pode ser encontrada no APÊNDICE B deste trabalho.

\subsubsection{Caracterização dos pós reagidos após o ciclo de hidretação}

Após o ciclo de hidretação, para avaliar a estabilidade das fases formadas após a síntese do TiFe, bem como a possível presença de hidrogênio residual nas amostras (que não podia ser revertido novamente em hidrogênio molecular após o ciclo de hidretação), as amostras reagidas (das composições 50:50 e 56:44) foram analisadas novamente por DRX (no mesmo difratômetro já descrito nos itens anteriores). Nestas análises foram realizadas varreduras angulares de $28^{\circ}$ a $97^{\circ}(2 \theta)$, com passo angular $0,05^{\circ}$ e tempo de contagem por passo de 10 segundos. A identificação das fases presentes nas amostras, bem como a determinação do parâmetro de rede, do tamanho médio de cristalito e da microdeformação da fase TiFe, seguiram os mesmos procedimentos já descritos anteriormente. Uma estimativa de hidrogênio 
residual no composto TiFe após o ciclo de hidretação foi obtida a partir da lei de Vegard, utilizando o deslocamento (antes e após ciclo) do pico (110) da fase $\mathrm{TiFe}$ (ou da fase TiFe supersaturada de Ti) das amostras reagidas em relação ao pico (110) da solução sólida $\mathrm{TiFeH}_{0,06}$. Análises por absorção de radiação infravermelha também foram utilizadas para estimar essas quantidades (IV, analisador LECO ${ }^{\circledR}$ modelo TCHEN-600).

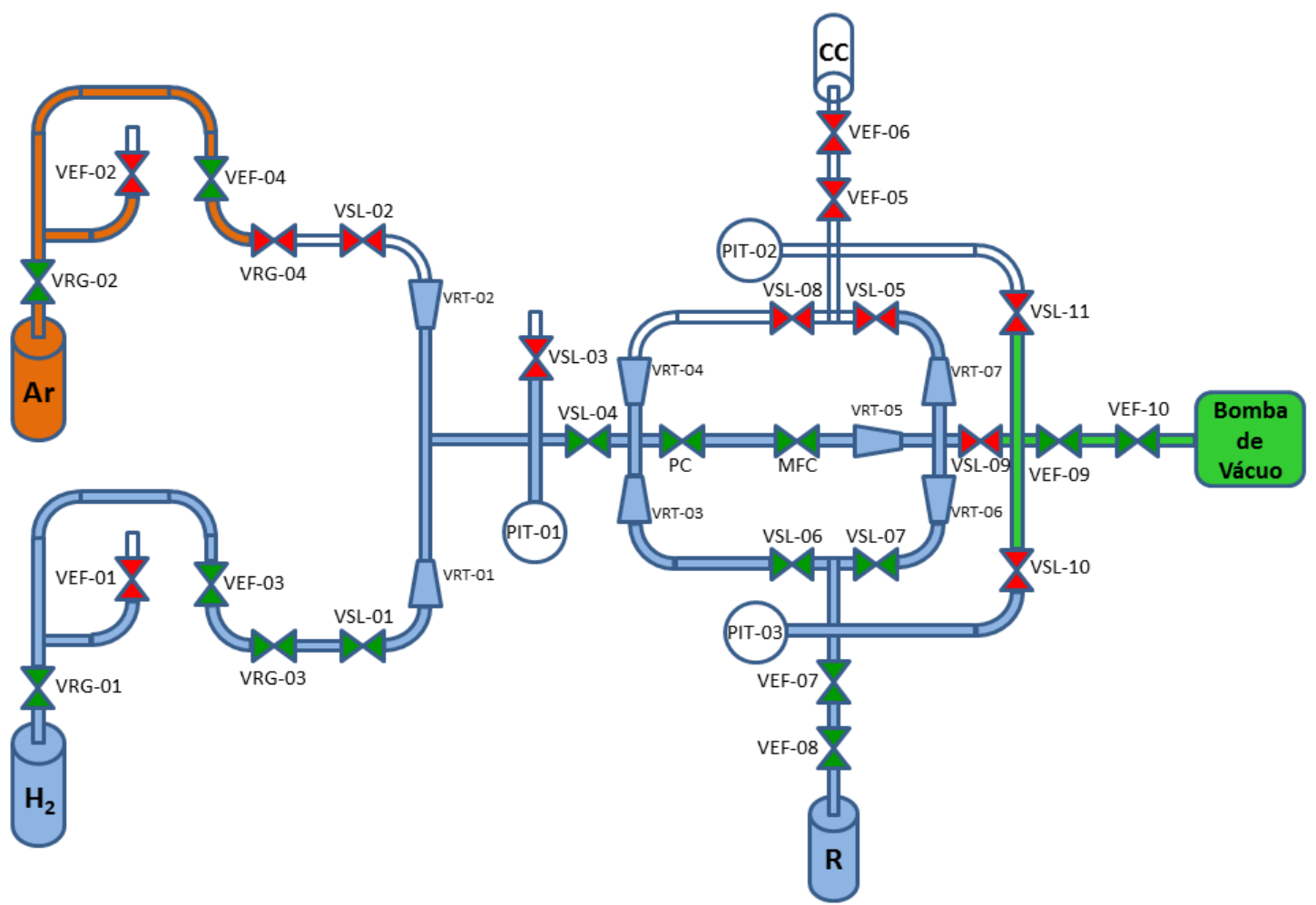

VEF = Válvula esfera; VRG = Válvula agulha; VSL = Válvula solenoide; VRT = Válvula retentora direcional; PIT = Medidor de pressão; $P C=$ Controlador de pressão; MFC = Controlador de fluxo; CC = Cilindro de controle; $R=$ Reator.

FIGURA 22 - Ilustração esquemática simplificada do equipamento do tipo Sievert construído pelo LMI (CCTM/IPEN) e utilizado no estudo das propriedades de armazenamento de hidrogênio do TiFe. 


\section{RESULTADOS E DISCUSÃO}

\subsection{Moagem dos pós de partida $\left(\mathrm{TiH}_{2}\right.$ e Fe)}

$\mathrm{Na}$ FIGURA 23 são apresentados os termogramas referentes às análises por DSC e TG do pó hidretado de $\mathrm{Ti}\left(\mathrm{TiH}_{2}\right)$, utilizado como um dos materiais de partida nas moagens. No termograma oriundo da análise por DSC, podemos observar dois picos endotérmicos, em aproximadamente 518 e $582^{\circ} \mathrm{C}$, característicos da decomposição do $\mathrm{TiH}_{2}$ [81]. Já no termograma da análise por TG, observamos uma liberação de hidrogênio correspondente a $4,1 \%$ em massa de $\mathrm{Ti}$, valor próximo ao esperado teoricamente $(4,04 \% \mathrm{em}$ massa de Ti). Tais resultados indicam que o pó hidretado de $\mathrm{Ti}$ pode ser considerados em boa parte como $\mathrm{TiH}_{2}$, justificando assim a sua utilização nas moagens que se sucederam.

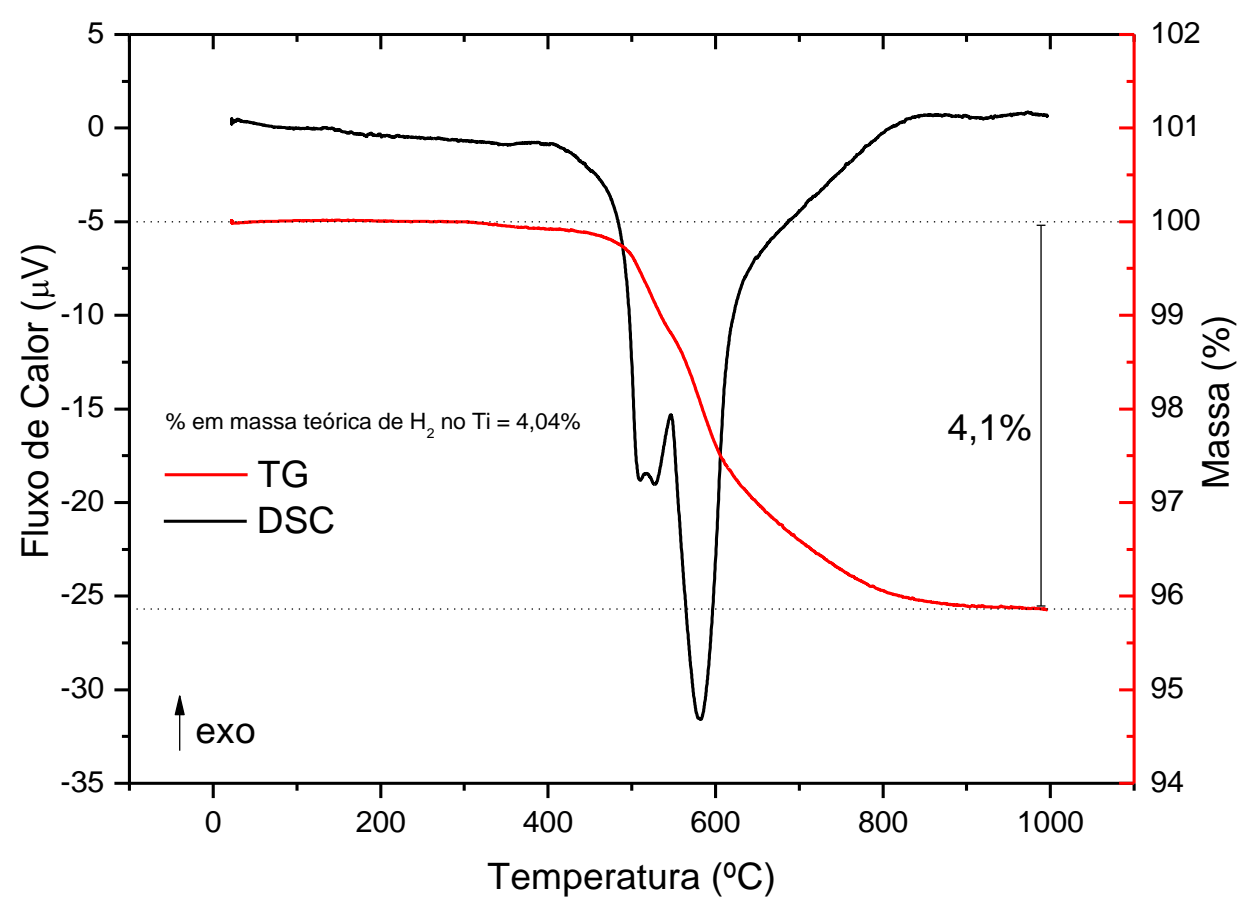

FIGURA 23 - Termogramas (DSC e TG) do pó de $\mathrm{TiH}_{2}$ utilizado como um dos materiais de partida nas moagens.

Com relação às análises por DRX dos pós de partida $\left(\mathrm{TiH}_{2}\right.$ e $\left.\mathrm{Fe}\right)$, observa-se nos difratogramas da FIGURA 24 a presença majoritária das fases $\alpha \mathrm{TiH}_{2}$ e $\alpha \mathrm{Fe}$ (ver FIGURA 24a), bem como o alinhamento do pico de difração (110) do Fe com o padrão obtido na base de dados PDF-2 (ver FIGURA 24b). 


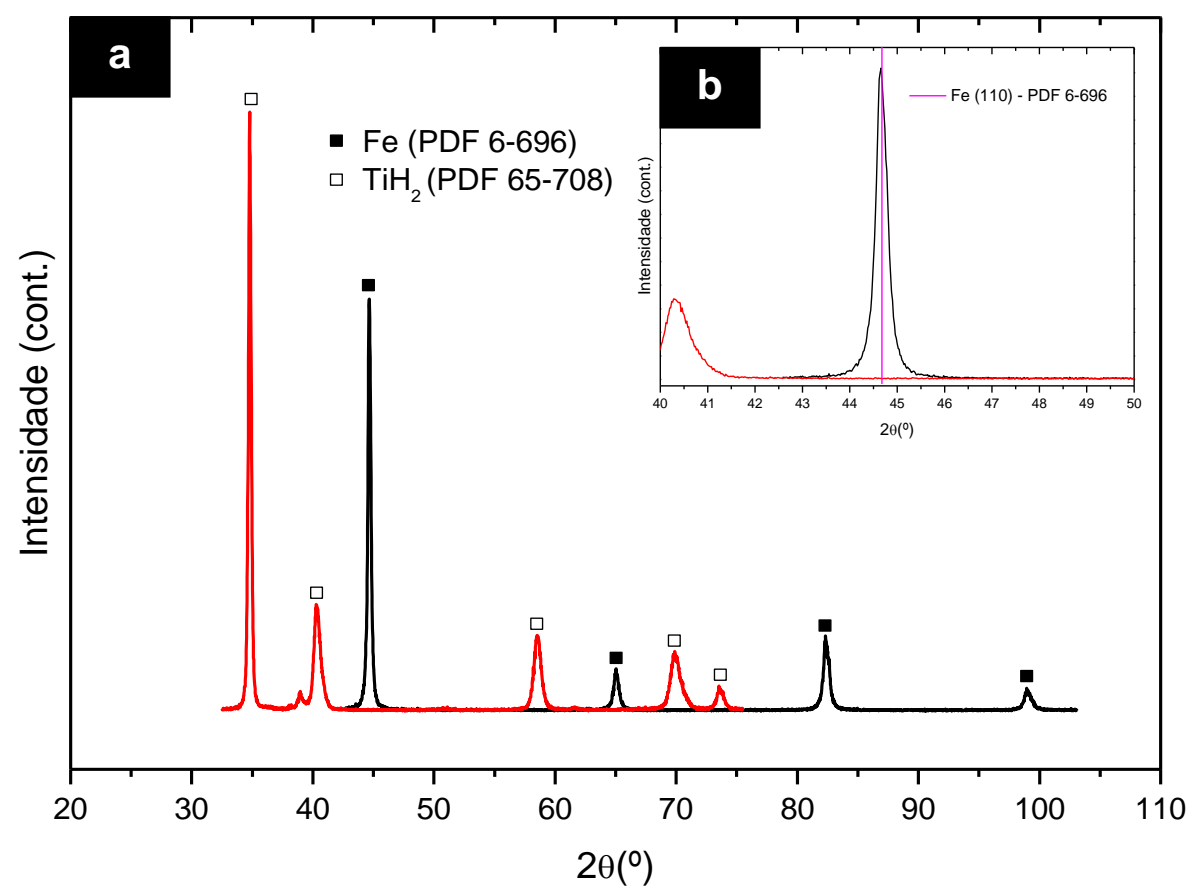

FIGURA 24 - Difratogramas de raios $X$ (DRX) dos pós de partida $\left(\mathrm{TiH}_{2}\right.$ e $\mathrm{Fe}$ ) utilizados nas moagens das amostras: (a) Visão geral das fases presentes; (b) Visão expandida na região do pico (110) da fase Fe.

Ainda sobre os materiais de partida, também foi avaliada a possível presença de contaminantes por EDXRF, cujos resultados são apresentados na TABELA 3. Nesta, podemos observar que os valores obtidos para a contaminação inicial dos pós estão todos próximos aos apresentados pelo fornecedor. Embora, seja possível destacar uma maior contaminação inicial por alumínio (Al) no pó de Ti (0,14\% em massa de Ti).

TABELA 3 - Contaminantes presentes nos materiais de partida.

\begin{tabular}{ccc}
\hline $\begin{array}{c}\text { Material de partida/ } \\
\text { Contaminantes } \\
(\% \text { em massa })\end{array}$ & $\begin{array}{c}\text { Pó de Ti }\left(A E E^{\circledR}, \text { pureza }\right. \\
\text { nominal } 99,7 \%)\end{array}$ & $\begin{array}{c}\text { Pó de Fe }\left(A E E^{\circledR}, \text { pureza }\right. \\
\text { nominal } 99,9 \%)\end{array}$ \\
\hline Al & $0,14 \pm 0,02$ & n.o. \\
$\mathrm{Cu}$ & $0,03 \pm 0,01$ & n.o. \\
$\mathrm{Si}$ & $0,03 \pm 0,01$ & n.o. \\
$\mathrm{Zn}$ & n.o. & $0,04 \pm 0,01$ \\
\hline
\end{tabular}

n.o. = não observado.

Feita esta avaliação inicial, na TABELA 4 são apresentados os rendimentos (\% da massa retirada do recipiente em relação à massa inicial) em 
função do tempo de moagem das amostras, onde, para facilitar a possível reprodutibilidade dos resultados, também foram calculadas as energias totais fornecidas ao pó moído $\left(E_{t}\right)$, baseadas no modelo simplificado apresentado no APÊNDICE A. Tais resultados serão avaliados em conjunto com os difratogramas e micrografias obtidos após as moagens das amostras de ambos os lotes (composições 50:50 e 56:44), bem como com os resultados das análises por EDS de microrregiões dessas amostras (TABELA 7).

TABELA 4 - Rendimentos (\% em massa) e energia total fornecida pelo sistema ao pó moído $\left(E_{t}\right)$ após as moagens por diferentes tempos das amostras das composições 50:50 e 56:44.

\begin{tabular}{|c|c|c|c|c|}
\hline \multirow{3}{*}{$\begin{array}{l}\text { Tempo de } \\
\text { moagem } \\
\text { (h) }\end{array}$} & \multicolumn{2}{|c|}{ Composição nominal (Ti:Fe) } & \multirow{3}{*}{$\begin{array}{c}E_{t} \\
(\mathrm{Wh} / \mathrm{g})\end{array}$} & \multirow{3}{*}{$\begin{array}{l}\text { Rendimento } \\
\text { (\% em massa) }\end{array}$} \\
\hline & \multicolumn{2}{|c|}{ at. (\%) } & & \\
\hline & $\mathrm{Ti}$ & $\mathrm{Fe}$ & & \\
\hline 5 & \multirow{4}{*}{50} & \multirow{4}{*}{50} & 0,8 & 92 \\
\hline 10 & & & 1,6 & 90 \\
\hline 25 & & & 4,1 & 93 \\
\hline 40 & & & 6,6 & 95 \\
\hline 5 & \multirow{4}{*}{56} & \multirow{4}{*}{44} & 0,8 & 90 \\
\hline 10 & & & 1,6 & 92 \\
\hline 25 & & & 4,1 & 90 \\
\hline 40 & & & 6,6 & 92 \\
\hline
\end{tabular}

Pode-se observar na TABELA 4 que a aderência dos pós ao ferramental de moagem foi controlada com sucesso em todos os experimentos (rendimentos $\geq 90 \%$ ). Há que se dizer, contudo, que em alguns casos ainda foram observadas regiões de concentração de massa após as moagens, principalmente no fundo do recipiente de moagem. Embora, estas regiões pudessem ser removidas facilmente com o auxilio de uma espátula.

Apesar do referido controle da aderência, como mostram os difratogramas da FIGURA 26 e FIGURA 27, em nenhuma das moagens foi observada a formação do composto $\mathrm{TiFe}$. $\mathrm{O} \mathrm{TiH}_{2}$ atuou nesses casos como um ACP intrínseco, evitando não somente a aderência dos pós ao ferramental de moagem, mas também a formação do próprio composto. De fato, nos 
difratogramas das amostras moídas discriminam-se apenas as reflexões das fases hidreto $\left(\alpha \mathrm{TiH}_{2}\right)$ e $\alpha \mathrm{Fe}$, além da formação das soluções sólidas $\mathrm{Fe}(\mathrm{Ti})$, que podem ser verificadas mais claramente através do deslocamento para a esquerda do pico (110) da fase Fe. Nestes casos, segundo a Lei de Vegard, o aumento do deslocamento ao longo do processo de moagem está diretamente relacionado a um maior teor de solutos nas soluções (e por consequência um menor teor de $\mathrm{TiH}_{2}$ livre), fenômeno que parece aumentar proporcionalmente com o tempo de moagem e a quantidade de $\mathrm{Ti}$ em excesso disponível nas moagens, como indicam as curvas da FIGURA 25, cujos resultados estão sintetizados na TABELA 5. Resultados semelhantes, no que concerne a formação das soluções sólidas $\mathrm{Fe}(\mathrm{Ti})$, já haviam sido observados por Novakova et al. (2000) na moagem do sistema $\mathrm{TiH}_{2}-\mathrm{Fe}$. No mesmo trabalho, os autores observaram também que, mesmo após 60 horas de moagem, 0 material moído ainda apresentava um elevado teor de soluções sólidas, além do hidreto $\mathrm{TiFeH}_{\mathrm{x}}$, um indicativo de que a simples moagem não levaria a síntese completa da fase desejada.

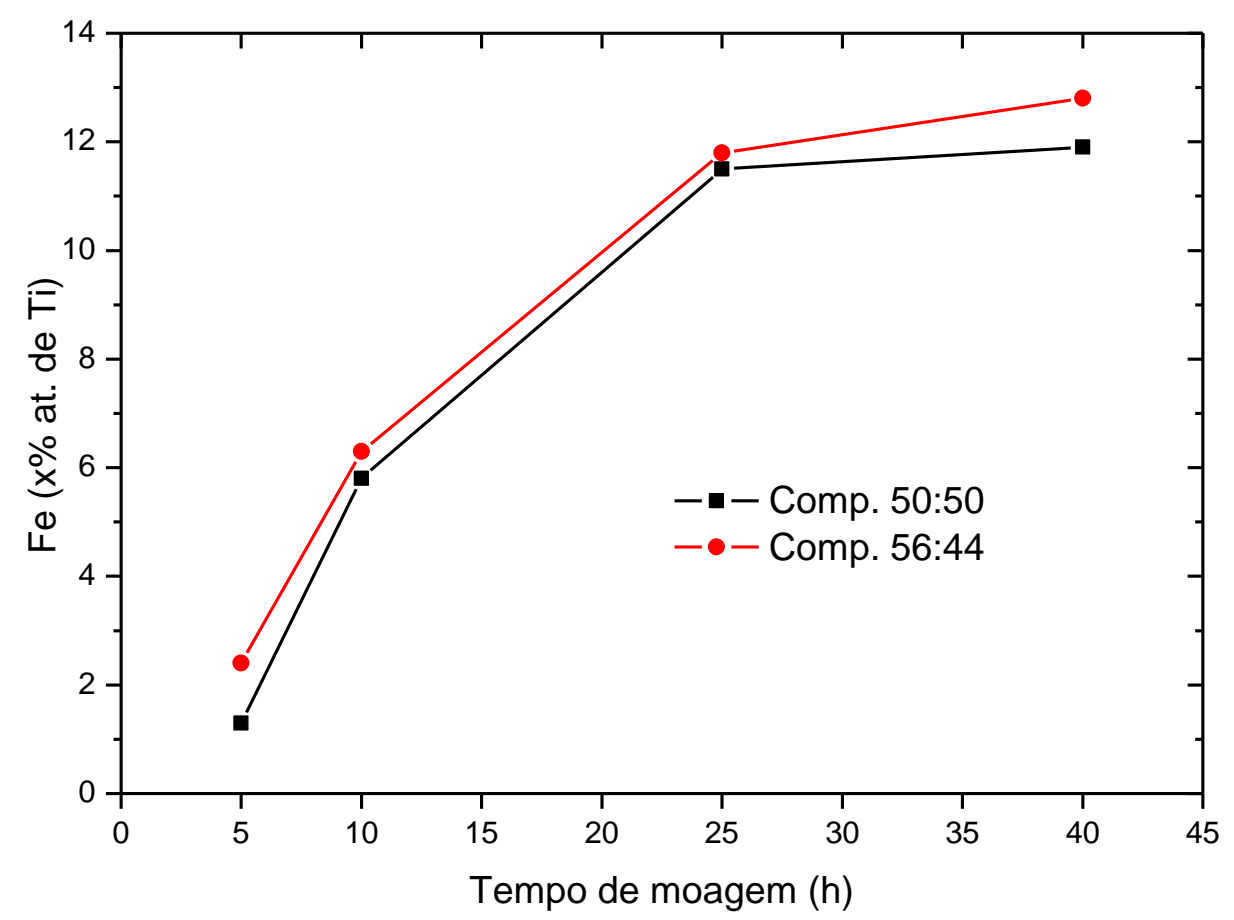

FIGURA 25 - Curvas da estimativa da porcentagem atômica de Ti em solução no Fe após as moagens por diferentes tempos das composições 50:50 e 56:44. 
Ainda nos difratogramas, de ambos os lotes composicionais, observa-se um alargamento nos perfis de picos de difração, e a consequente diminuição da intensidade das reflexões, em função do aumento do tempo de moagem, resultado do maior grau de amorfização do material moído (perda da cristalinidade). Tal fenômeno é característico da moagem de alta energia, em virtude das sucessivas colisões das bolas com as partículas metálicas dos pós ao longo do processo de moagem, que provocam uma severa deformação plástica, aumentando sobremaneira a densidade de defeitos cristalinos. Resultados semelhantes também já haviam sido observados por diversos autores da literatura revisada [2-7, 61].

TABELA 5 - Estimativas da porcentagem atómica de Ti em solução no Fe após as moagens por diferentes tempos das composições 50:50 e 56:44.

\begin{tabular}{|c|c|c|c|}
\hline \multirow{3}{*}{$\begin{array}{l}\text { Tempo de moagem } \\
\text { (h) }\end{array}$} & \multicolumn{2}{|c|}{ Composição nominal (Ti:Fe) } & \multirow{3}{*}{$\mathrm{Fe}(\mathrm{x} \%$ at. de $\mathrm{Ti})$} \\
\hline & \multicolumn{2}{|c|}{ at. (\%) } & \\
\hline & $\mathrm{Ti}$ & $\mathrm{Fe}$ & \\
\hline 5 & \multirow{4}{*}{50} & \multirow{4}{*}{50} & 1,3 \\
\hline 10 & & & 5,8 \\
\hline 25 & & & 11,5 \\
\hline 40 & & & 11,9 \\
\hline 5 & \multirow{4}{*}{56} & \multirow{4}{*}{44} & 2,4 \\
\hline 10 & & & 6,3 \\
\hline 25 & & & 11,8 \\
\hline 40 & & & 12,8 \\
\hline
\end{tabular}

$\mathrm{Fe}(\mathrm{x} \%$ at. de $\mathrm{Ti})$ se refere a porcentagem atômica de Ti em solução sólida no $\mathrm{Fe}$, estimada a partir da lei de Vegard, utilizando o deslocamento do pico (110) da fase Fe das amostras moídas em relação ao pico (110) da solução sólida $\mathrm{Fe}_{9,64} \mathrm{Ti}_{0,36}$. 

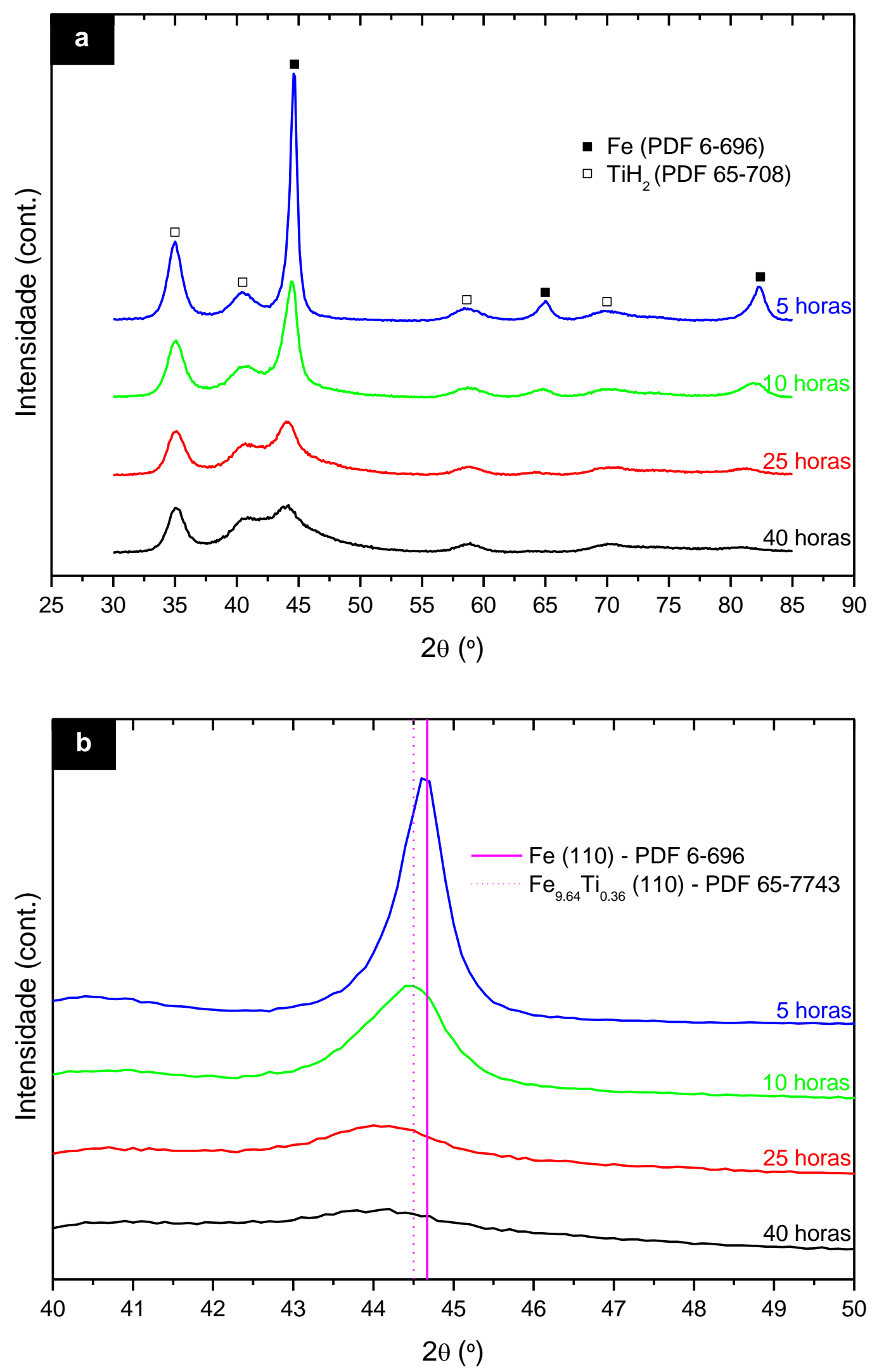

FIGURA 26 - Difratogramas de raios X (DRX) das amostras moídas por diferentes tempos da composição 50:50: Visão geral das fases presentes; (b) Visão expandida na região do pico (110) da fase Fe. 

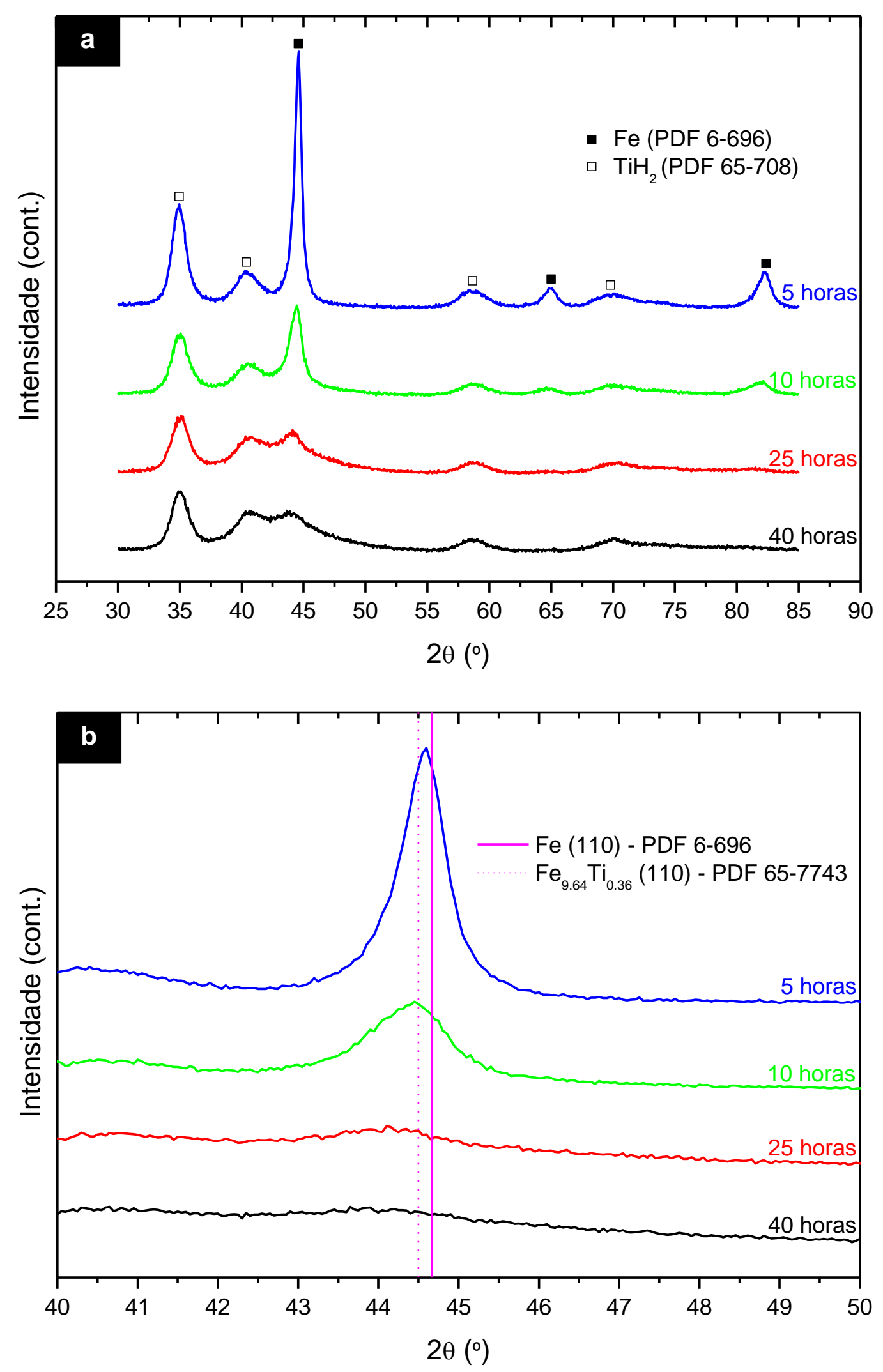

FIGURA 27 - Difratogramas de raios X (DRX) das amostras moídas por diferentes tempos da composição 56:44: Visão geral das fases presentes; (b) Visão expandida na região do pico (110) da fase Fe. 
Alguns dos resultados supracitados também podem ser verificados com o auxilio das micrografias (de elétrons retroespalhados) apresentadas na FIGURA 28 e FIGURA 29, principalmente nas amostras moídas por 5 horas, de ambos os lotes composicionais (50:50 e 56:44), onde ainda observam-se claramente regiões com finas lamelas das fases $\mathrm{TiH}_{2}$ e $\mathrm{Fe}$ (lamelas $<100 \mathrm{~nm}$ ), além de regiões isoladas ricas em Fe (de até $1 \mu \mathrm{m}$ ). A formação destas regiões pode ser um indício do menor grau de dispersão da fase $\mathrm{Fe}$ frente à fase $\mathrm{TiH}_{2}$, o que poderia resultar na formação de regiões mais ricas em Ti após as moagens. Realmente, as regiões lamelares das amostras moídas por 5 horas, de ambas as composições, apresentaram um desvio composicional em relação ao valor nominal de até $5 \%$ em excesso de $\mathrm{Ti}$, como mostram os resultados apresentados na TABELA 7, referentes às análises por EDS de microrregiões das amostras moídas. É importante salientar que, no caso das amostras do lote 56:44, as regiões analisadas se apresentaram naturalmente mais ricas em $\mathrm{Ti}$, uma vez que, maiores porcentagens em massa de $\mathrm{Ti}$ foram adicionadas propositadamente nessas misturas.

A questão da variação composicional é típica dos estágios iniciais da moagem de alta energia e tende a se minimizar nos estágios mais avançados $[5,52]$. E de fato, nos estágios mais avançados, caso das moagens por 10 horas, independente da composição inicial, verificou-se que as lamelas das fases $\mathrm{TiH}_{2}$ e $\mathrm{Fe}$ já pareciam quase indistinguíveis (mais homogêneas), embora, algumas das regiões ricas em $\mathrm{Fe}$ (de até $0,4 \mu \mathrm{m}$ ) ainda se fizessem presentes, resultado este que ainda se refletiu na composição das regiões lamelares mais homogêneas (desvios de até $4 \%$ em excesso de Ti, TABELA 7). Neste estágio da moagem, em particular, é importante salientar que as regiões ricas em $\mathrm{Fe}$ ainda parecem ser, em boa parte, oriundas do menor grau de dispersão das fases, como indicam os resultados das análises pontuais por EDS apresentados na TABELA 7 (não foi verificada a contaminação por cromo (Cr) nas análises dessas regiões).

Em estágios ainda mais avançados das moagens (25 e 40h), de ambas as composições, já não se observam mais lamelas das fases $\mathrm{TiH}_{2}$ e $\mathrm{Fe}$ (completamente homogêneas dentro do limite de resolução do microscópio), e a variação composicional chegou a ser menor do que $2 \%$ em excesso de $\mathrm{Ti}$ (ver TABELA 7). Embora, como indiquem os difratogramas da FIGURA 26 e 
FIGURA 27, essa aparente homogeneidade não está relacionada à síntese do composto $\mathrm{TiFe}$, mas sim ao elevado grau de dispersão das fases presentes nas amostras $\left(\mathrm{TiH}_{2}\right.$ e $\left.\mathrm{Fe}\right)$. Ainda nestes estágios, apesar da aparente homogeneidade relatada, também foram observadas algumas pequenas regiões ricas em $\mathrm{Fe}$ (finas lamelas entre 0,1 e $0,3 \mu \mathrm{m}$ ). Contudo, estas regiões já pareciam, em boa parte, oriundas do desgaste do ferramental de moagem, resultados confirmados pelas análises pontuais por EDS destas regiões, que indicaram contaminação por cromo (até $0,73 \%$ at. de $\mathrm{Cr}$ após $40 \mathrm{~h}$ de moagem dos pós do lote 50:50, TABELA 7).

Uma melhor avaliação sobre a presença de contaminantes após as moagens pode ser realizada a partir dos resultados apresentados na TABELA 6 , referentes às análises por EDXRF das amostras moídas por diferentes tempos do lote composicional 50:50. Nesta, observa-se de fato um aumento significativo na presença de cromo ( $\mathrm{Cr}$ ), principalmente nas moagens por maiores tempos, além de um aumento na contaminação por cálcio (Ca) e manganês (Mn). As presenças dos demais contaminantes, como o alumínio $(A l)$, o cobre $(\mathrm{Cu})$ e o zinco $(\mathrm{Zn})$, podem ser justificadas, em sua maior parte, pela contaminação inicial dos pós de partida (ver TABELA 3). Tais resultados, de uma forma geral, indicam uma baixa contaminação dos materiais moídos, uma vez que, mesmo nos piores casos (25 e 40h), a soma dos contaminantes potencialmente oriundos do desgaste do ferramental de moagem ( $\mathrm{Cr}$ e $\mathrm{Mn}$ ) não ultrapassou o valor de 0,2\% em massa das amostras. Mais informações sobre a presença de contaminantes oriundos do desgaste do ferramental de moagem são encontradas na literatura revisada $[3,52,54]$. 
TABELA 6 - Contaminantes presentes nas amostras moídas por diferentes tempos da composição 50:50.

\begin{tabular}{ccccc}
\hline $\begin{array}{c}\text { Tempo de moagem/ } \\
\text { Contaminantes } \\
(\% \text { em massa })\end{array}$ & $\mathbf{5}$ horas & 10 horas & $\mathbf{2 5}$ horas & $\mathbf{4 0 ~ h o r a s}$ \\
\hline $\mathrm{Al}$ & $0,14 \pm 0,01$ & $0,25 \pm 0,01$ & $0,21 \pm 0,01$ & $0,16 \pm 0,01$ \\
$\mathrm{Ca}$ & $0,21 \pm 0,01$ & $0,25 \pm 0,01$ & $0,18 \pm 0,01$ & $0,10 \pm 0,01$ \\
$\mathrm{Cu}$ & $0,07 \pm 0,01$ & $0,07 \pm 0,01$ & $0,07 \pm 0,01$ & $0,09 \pm 0,01$ \\
$\mathrm{Cr}$ & $0,03 \pm 0,01$ & $0,04 \pm 0,01$ & $0,12 \pm 0,01$ & $0,06 \pm 0,01$ \\
$\mathrm{Mn}$ & $0,05 \pm 0,01$ & $0,06 \pm 0,01$ & $0,07 \pm 0,01$ & $0,06 \pm 0,01$ \\
$\mathrm{Zn}$ & $0,03 \pm 0,01$ & $<0,02$ & $<0,02$ & $<0,02$ \\
\hline
\end{tabular}

Observando agora as micrografias (de elétrons secundários), apresentadas na FIGURA 30 e FIGURA 31, é possível notar nos pós moídos de ambas as composições, um aumento no tamanho de partículas ao longo do tempo, fruto da formação de agregados de partículas, algo que já havia sido observado por diversos autores da literatura revisada [2-5, 8]. De fato, nos primeiros estágios da moagem, especialmente da composição 56:44, se observa um grande número de pequenas partículas $(\sim 1 \mu \mathrm{m})$, que com 0 aumento do tempo de moagem acabaram se agregando em partículas maiores de aproximadamente $5 \mu \mathrm{m}$. A particular formação de menores partículas nos estágios iniciais da moagem do lote 56:44 pode estar relacionada com a maior porcentagem da fase hidreto na mistura dos pós de partida (os pós de hidretos são mais suscetíveis à fratura).

Em suma, apesar do relatado controle da aderência e do elevado grau de dispersão das fases de $\mathrm{TiH}_{2}$ e $\mathrm{Fe}$ (excluindo as moagens por 5 horas de ambos os lotes), a simples moagem dos pós aparentemente não levaria à síntese completa da fase desejada, o que justificou a busca de uma rota alternativa para tal fim. Aventou-se então a possibilidade da realização de tratamentos térmicos para a completa síntese do composto TiFe. Para tal, o processo de formação do composto foi investigado de forma mais detalhada por meio de análises por DSC e TG das amostras moídas do lote composicional 50:50. 

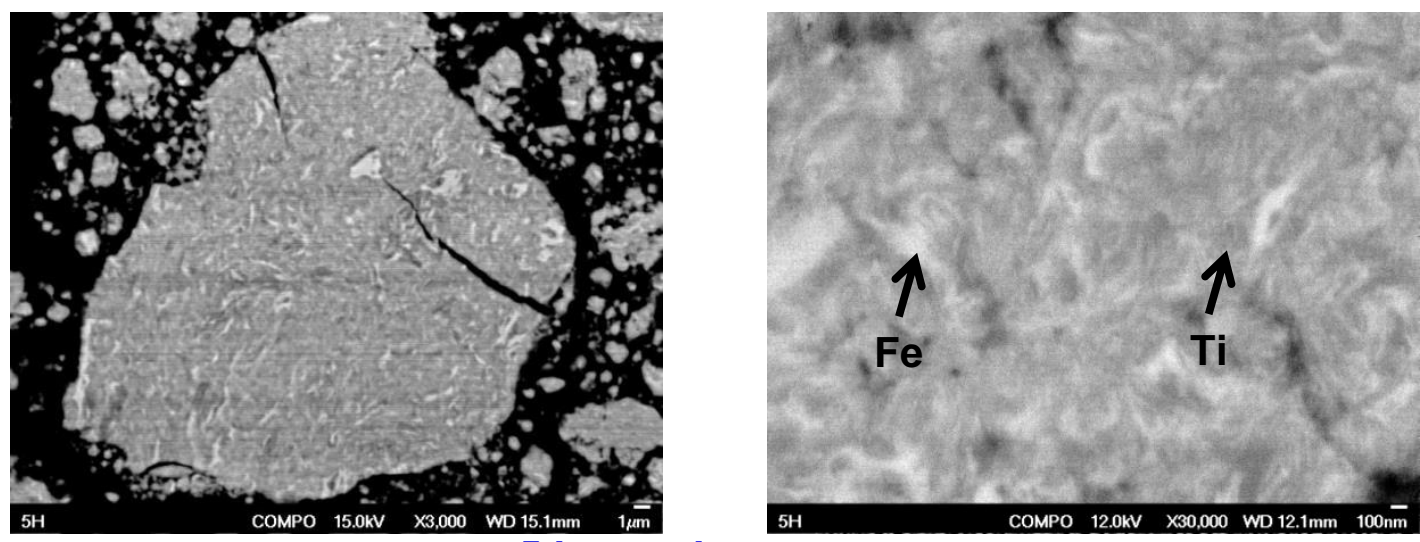

5 horas de moagem
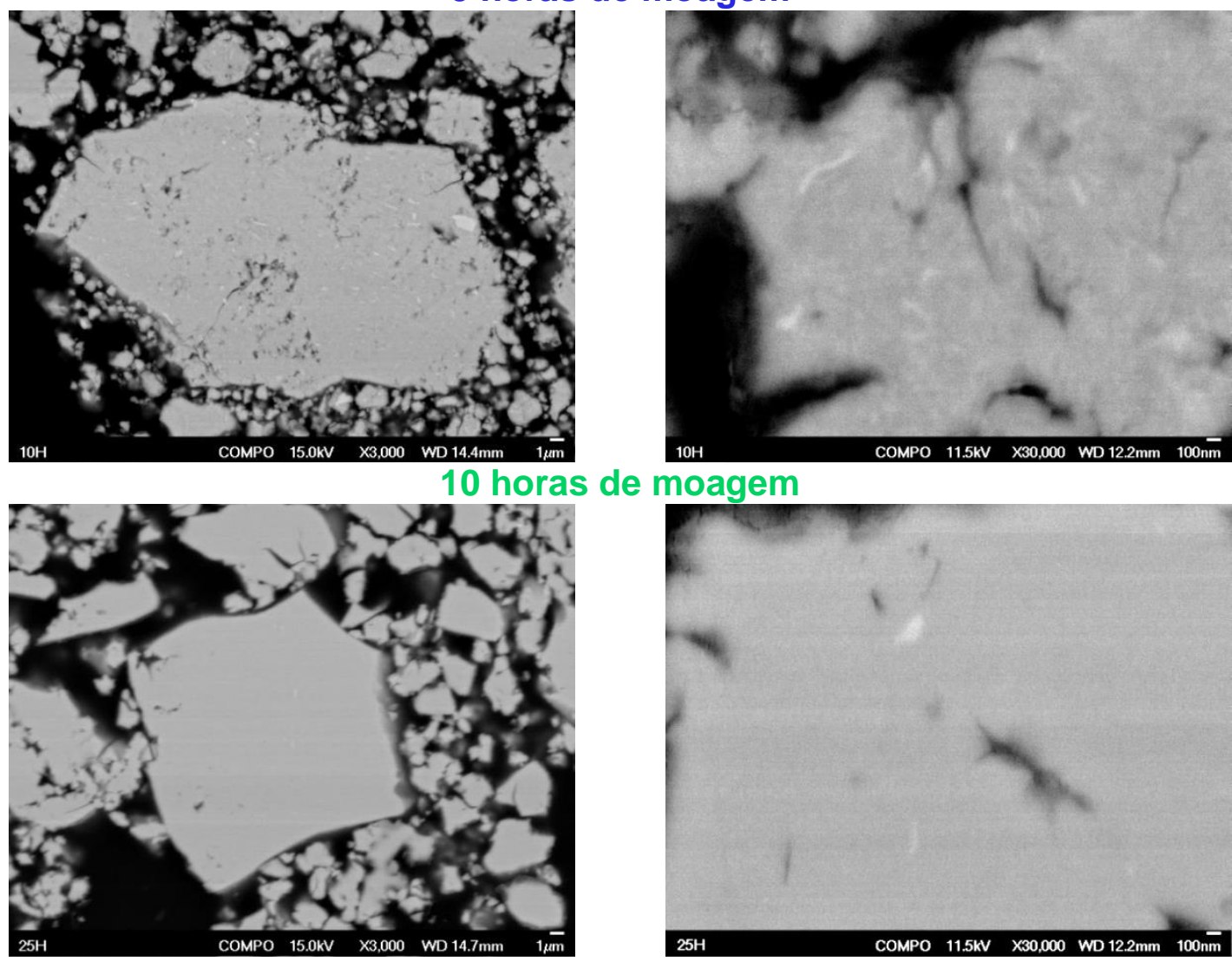

25 horas de moagem
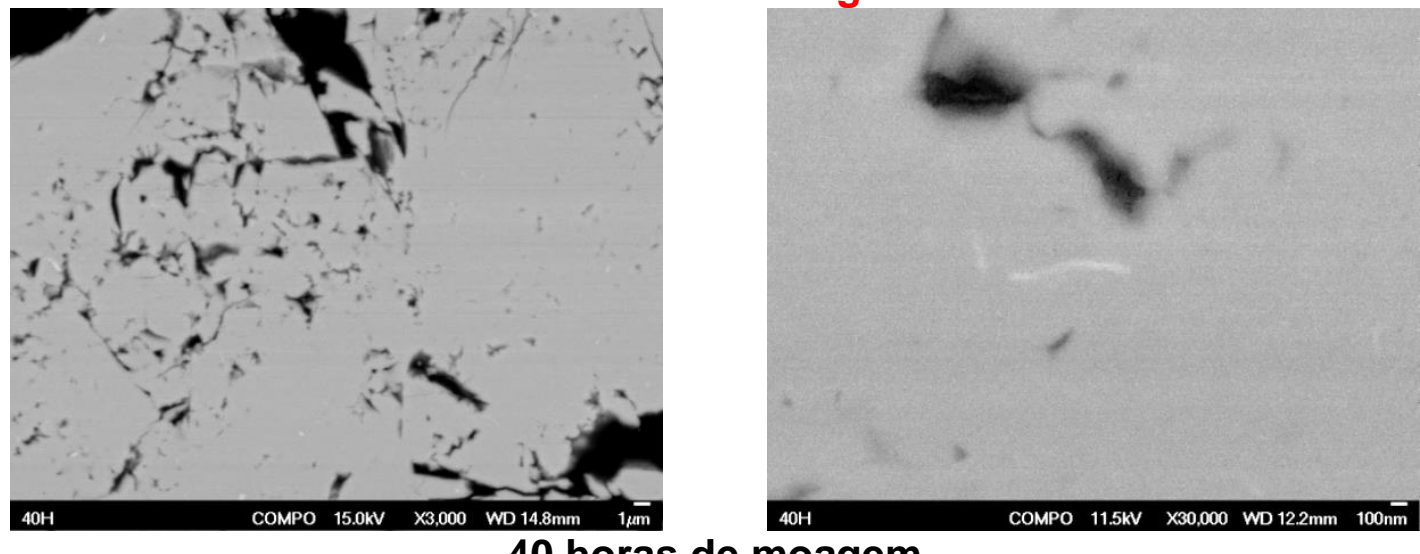

\section{0 horas de moagem}

FIGURA 28 - Micrografias de varredura de elétrons retroespalhados (MEVFEG) da microestrutura dos agregados soltos após a moagem por diferentes tempos da composição 50:50. 

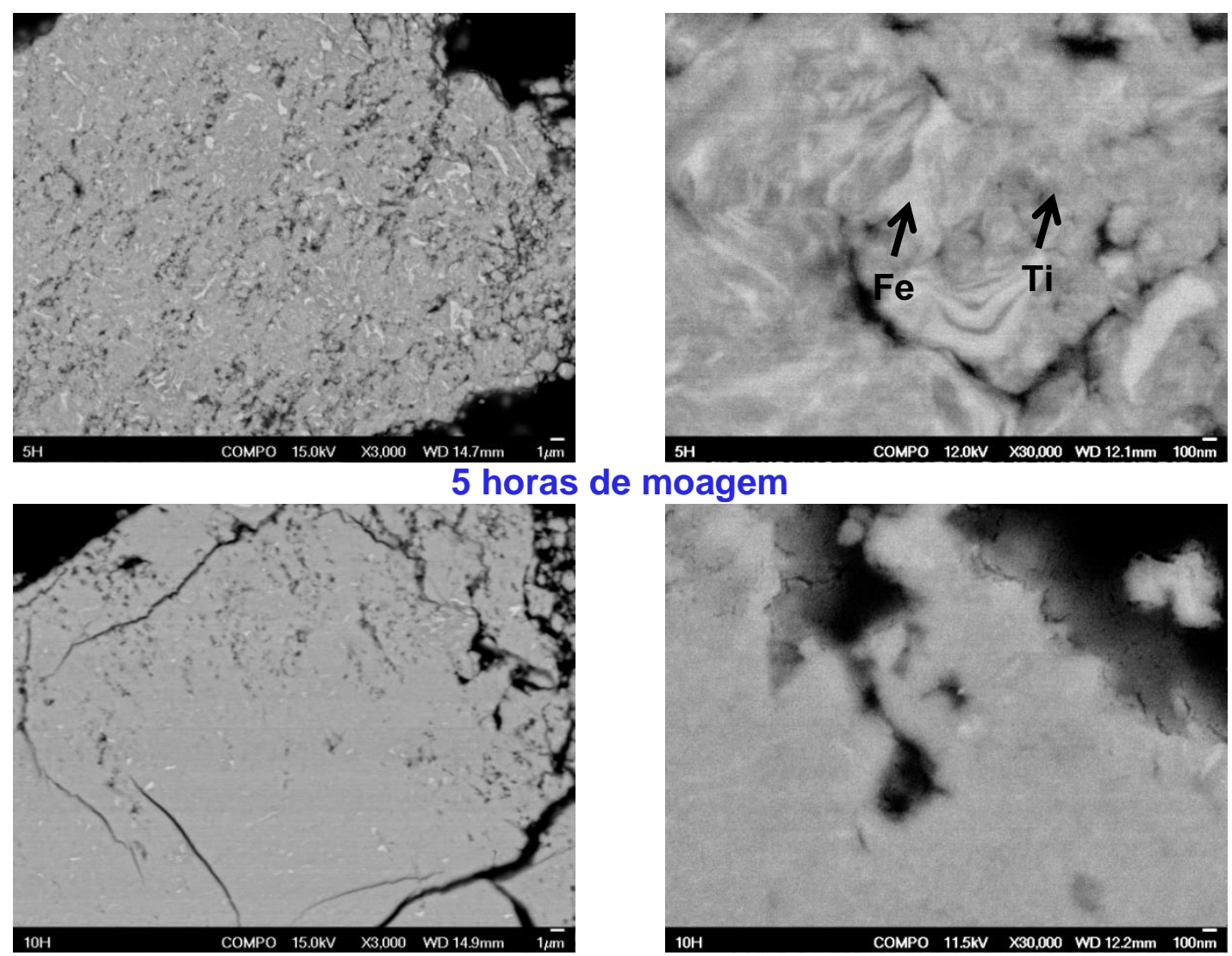

de moagem
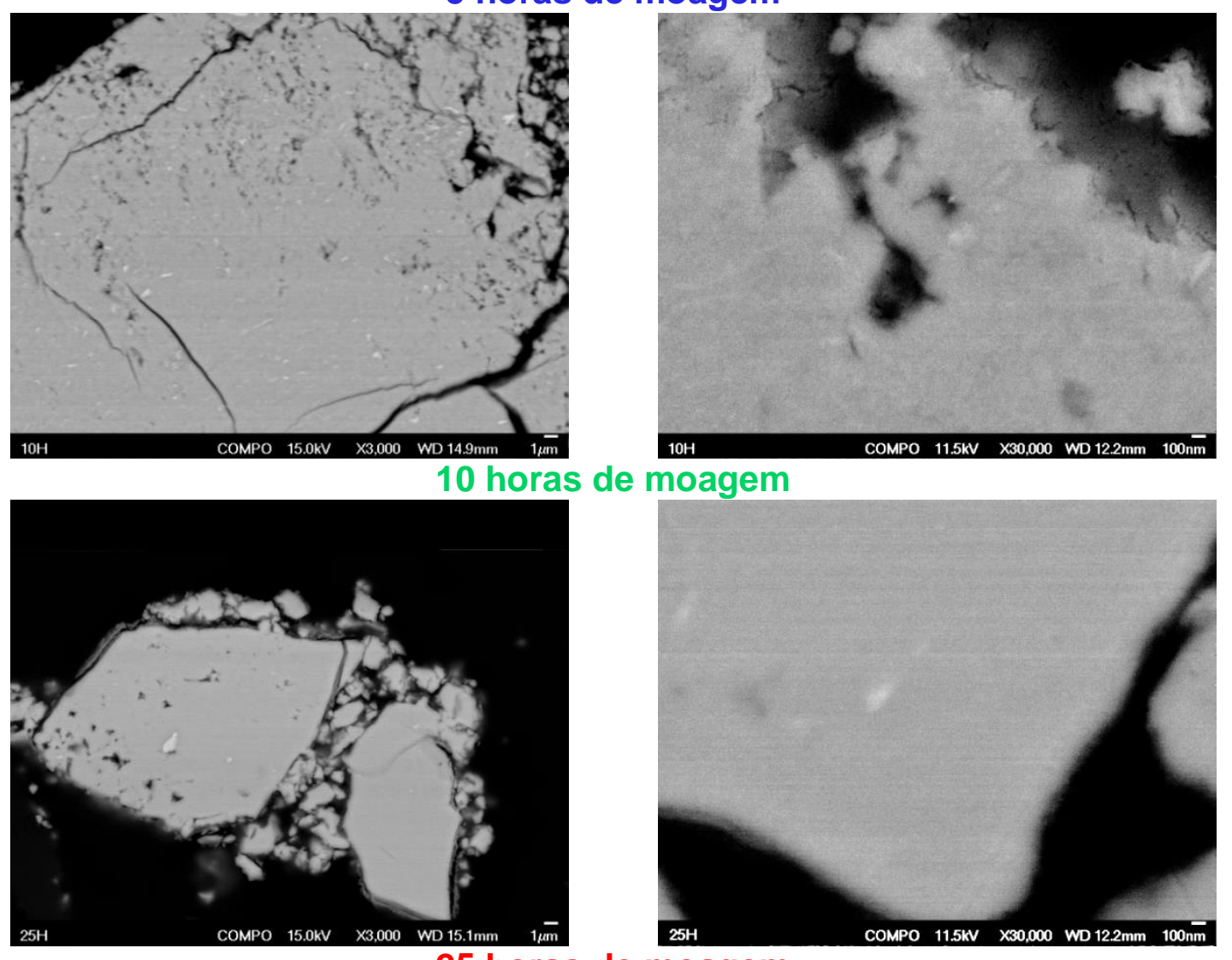

moagem
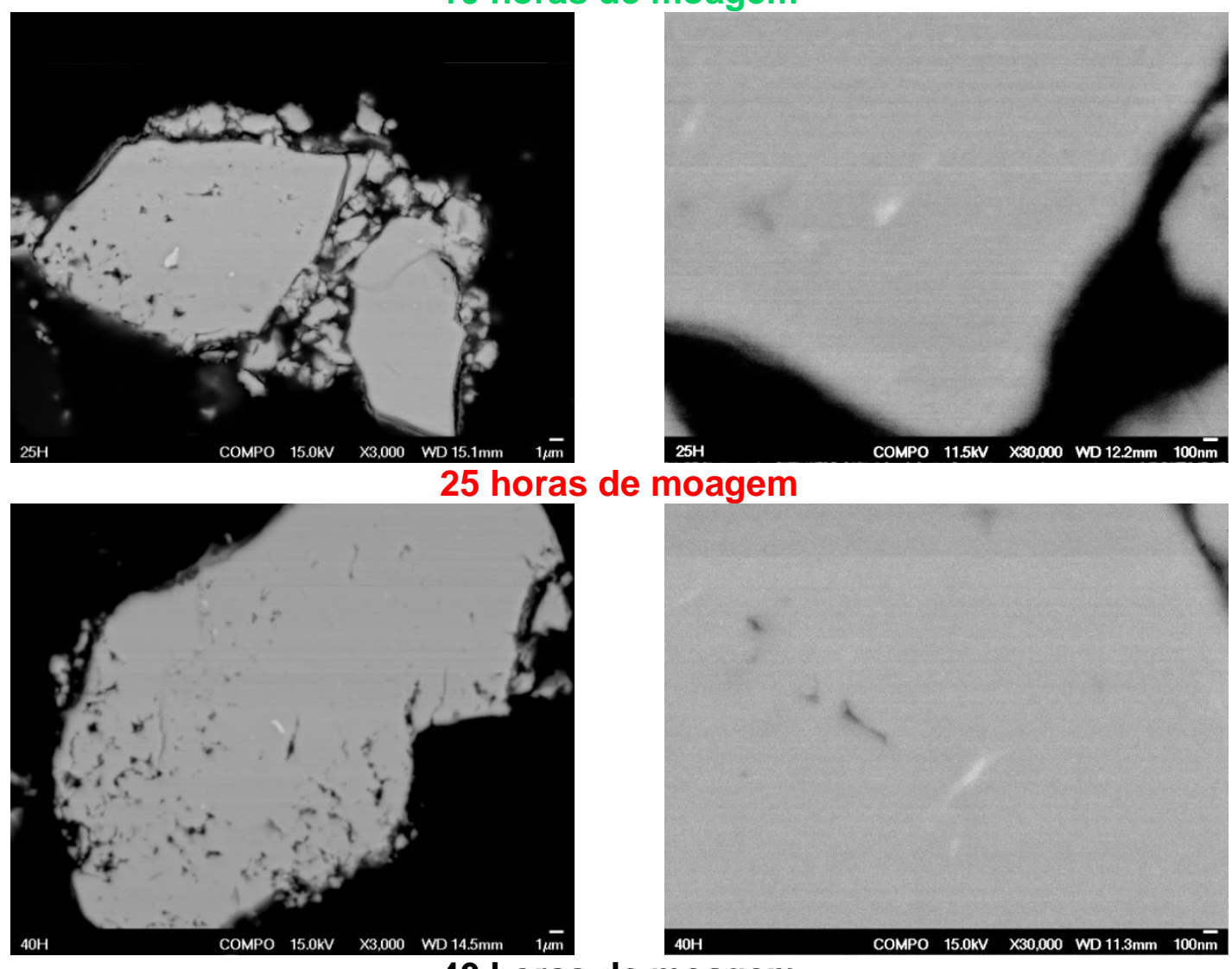

\section{0 horas de moagem}

FIGURA 29 - Micrografias de varredura de elétrons retroespalhados (MEVFEG) da microestrutura dos agregados soltos após a moagem por diferentes tempos da composição 56:44. 
TABELA 7 - Microanálises por EDS das amostras moídas por diferentes tempos das composições 50:50 e 56:44.

\begin{tabular}{|c|c|c|c|c|c|c|c|c|c|c|c|c|c|c|}
\hline \multirow{4}{*}{$\begin{array}{l}\text { Tempo de } \\
\text { moagem } \\
\text { (h) }\end{array}$} & \multicolumn{4}{|c|}{$\begin{array}{c}\text { Composição nominal } \\
\text { (Ti:Fe) }\end{array}$} & \multicolumn{10}{|c|}{ EDS } \\
\hline & \multicolumn{2}{|c|}{ at. (\%) } & \multicolumn{2}{|c|}{$\begin{array}{c}\text { wt. (\% em } \\
\text { massa) }\end{array}$} & \multicolumn{4}{|c|}{ Área (Ti:Fe) } & \multicolumn{6}{|c|}{ Pontual (Ti:Fe:Cr) } \\
\hline & \multirow{2}{*}{ Ti } & \multirow{2}{*}{$\mathrm{Fe}$} & \multirow{2}{*}{ Ti } & \multirow{2}{*}{$\mathbf{F e}$} & \multicolumn{2}{|c|}{ at. $\pm \sigma$ at. $(\%)$} & \multicolumn{2}{|c|}{ wt. $\pm \sigma w t . ~(\%$ em massa) } & \multicolumn{3}{|c|}{ at. (\%) } & \multicolumn{3}{|c|}{ wt. (\% em massa) } \\
\hline & & & & & Ti & $\mathbf{F e}$ & Ti & $\mathbf{F e}$ & Ti & $\mathrm{Fe}$ & $\mathrm{Cr}$ & Ti & $\mathrm{Fe}$ & $\mathrm{Cr}$ \\
\hline 5 & & & & & $52,7 \pm 0,4$ & $47,3 \pm 0,4$ & $48,8 \pm 0,4$ & $51,2 \pm 0,4$ & 10,40 & 89,60 & n.o. & 9,05 & 90,95 & n.o. \\
\hline 10 & & & & & $52,11 \pm 0,04$ & $47,89 \pm 0,04$ & $48,27 \pm 0,04$ & $51,73 \pm 0,04$ & 16,49 & 83,51 & n.o. & 14,49 & 85,51 & n.o. \\
\hline 25 & 50 & 50 & 46,15 & 53,85 & $50,94 \pm 0,16$ & $49,06 \pm 0,16$ & $47,11 \pm 0,16$ & $52,89 \pm 0,16$ & 19,82 & 79,54 & 0,64 & 17,5 & 81,89 & 0,61 \\
\hline 40 & & & & & $50,93 \pm 0,15$ & $49,07 \pm 0,15$ & $47,10 \pm 0,15$ & $52,90 \pm 0,15$ & 8,32 & 90,95 & 0,73 & 7,22 & 92,08 & 0,69 \\
\hline 5 & & & & & $58,62 \pm 0,29$ & $41,38 \pm 0,29$ & $54,85 \pm 0,29$ & $45,15 \pm 0,29$ & 41,11 & 58,89 & n.o. & 37,45 & 62,55 & n.o. \\
\hline 10 & & & & & $58,47 \pm 0,15$ & $41,53 \pm 0,15$ & $54,70 \pm 0,15$ & $45,30 \pm 0,15$ & 50,19 & 49,81 & n.o. & 46,36 & 53,64 & n.o. \\
\hline 25 & 56 & 44 & 52,17 & 47,83 & $57,7 \pm 0,4$ & $42,3 \pm 0,4$ & $53,9 \pm 0,4$ & $46,1 \pm 0,4$ & 31,12 & 68,43 & 0,44 & 27,94 & 71,63 & 0,43 \\
\hline 40 & & & & & $57,45 \pm 0,11$ & $42,55 \pm 0,11$ & $53,66 \pm 0,11$ & $46,34 \pm 0,11$ & 35,83 & 63,71 & 0,46 & 32,40 & 67,15 & 0,45 \\
\hline
\end{tabular}

A análise de área se refere à média de três áreas $\left(\sim 100 \mu \mathrm{m}^{2}\right)$ sobre partículas homogêneas e aleatórias com o respectivo desvio padrão da média; $\mathrm{A}$ análise pontual se refere à medida pontual sobre uma partícula visivelmente com maior teor de Fe; n.o. = não observado. 

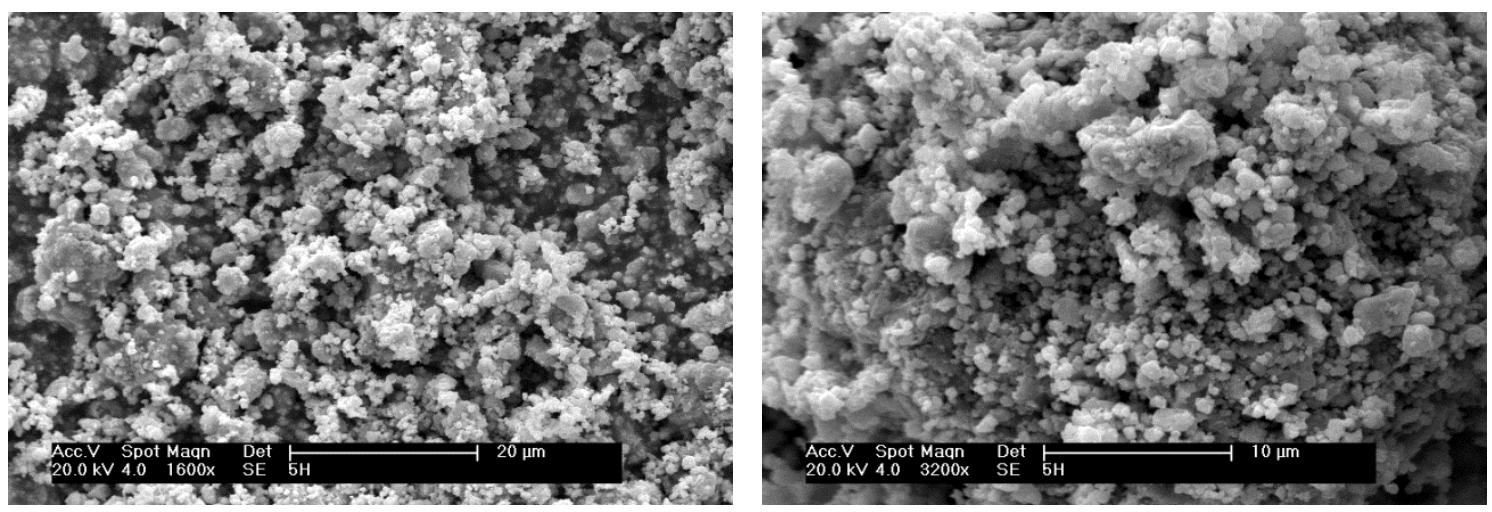

\section{5 horas de moagem}

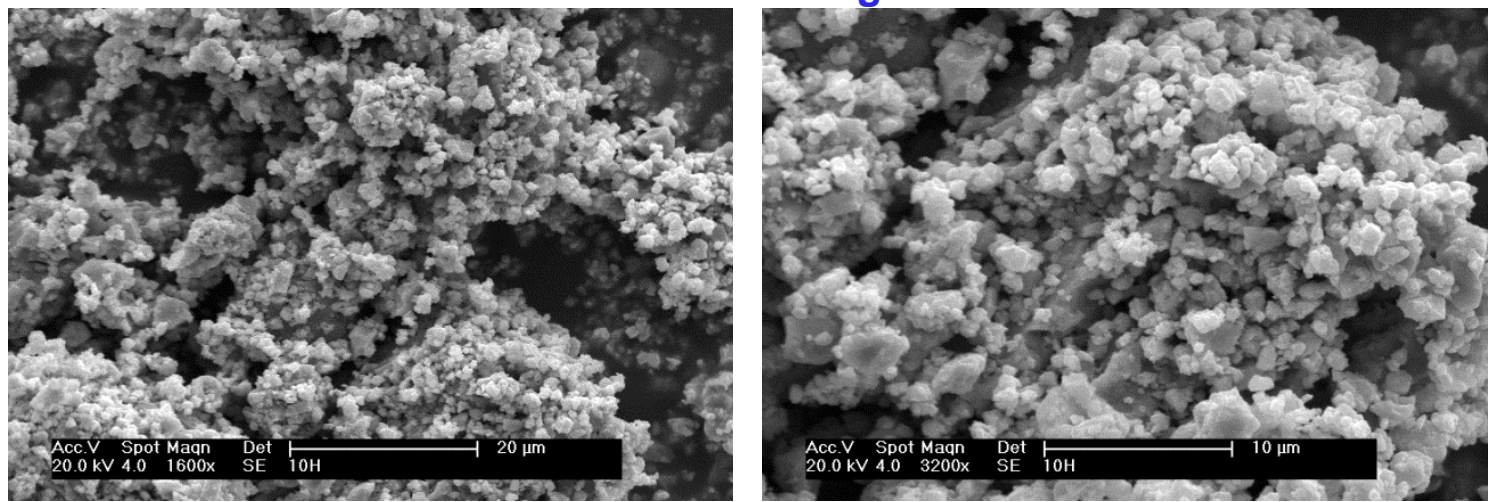

10 horas de moagem
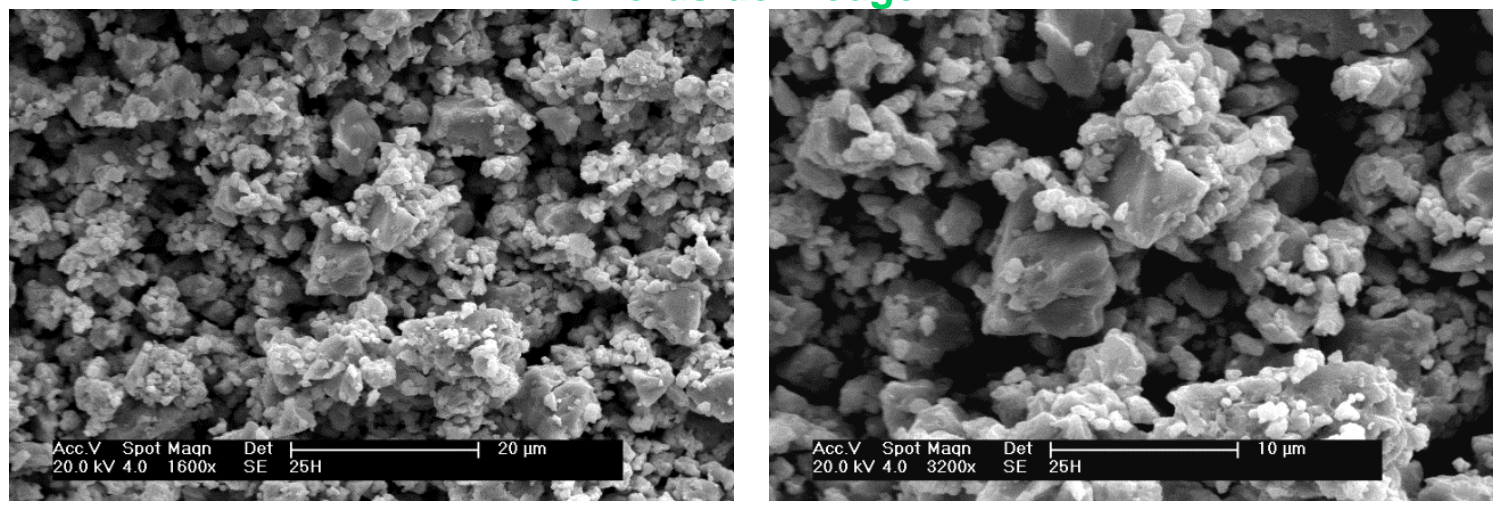

25 horas de moagem
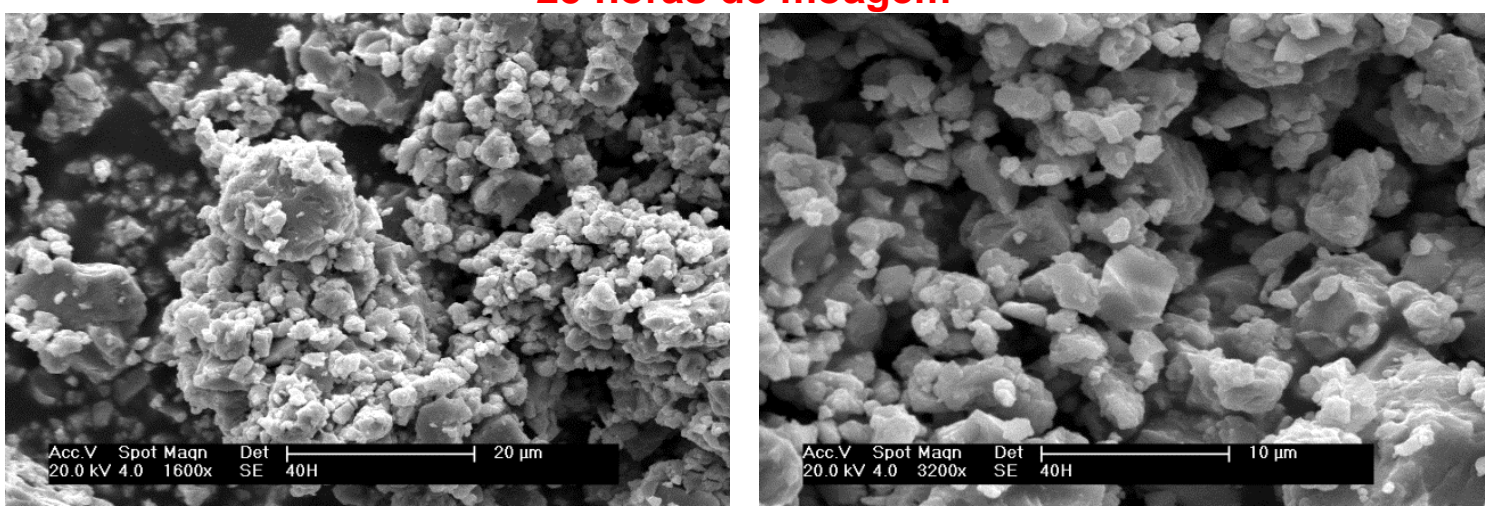

\section{0 horas de moagem}

FIGURA 30 - Micrografias de varredura de elétrons secundários (MEV) da forma dos agregados soltos após as moagens por diferentes tempos da composição 50:50. 

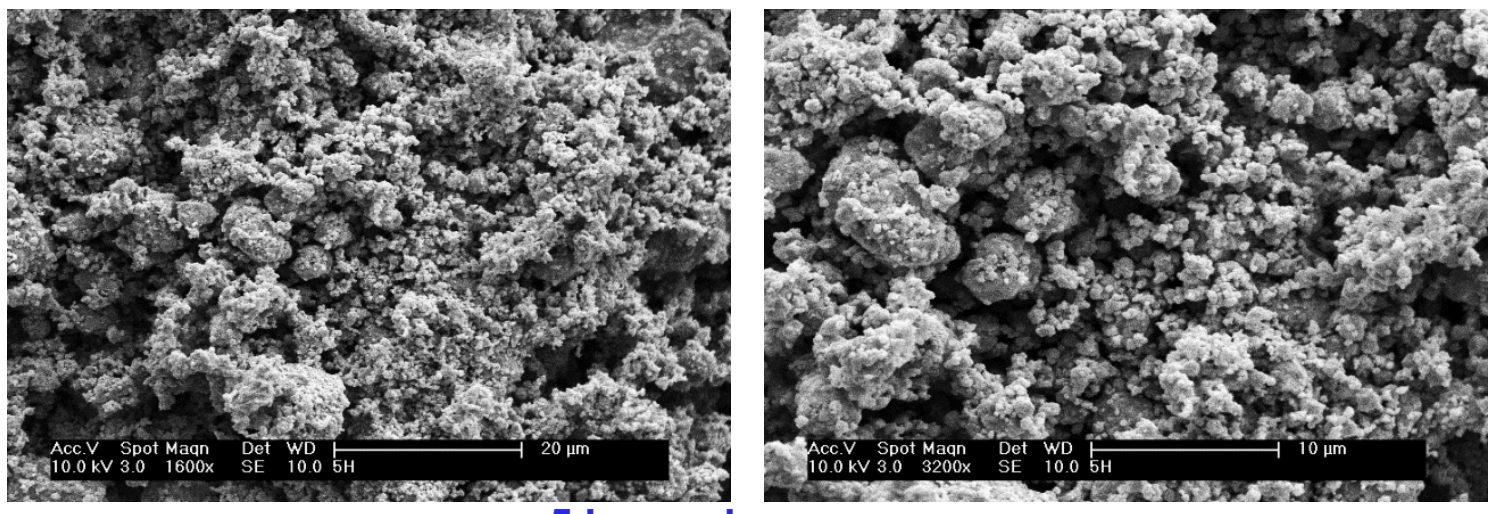

5 horas de moagem
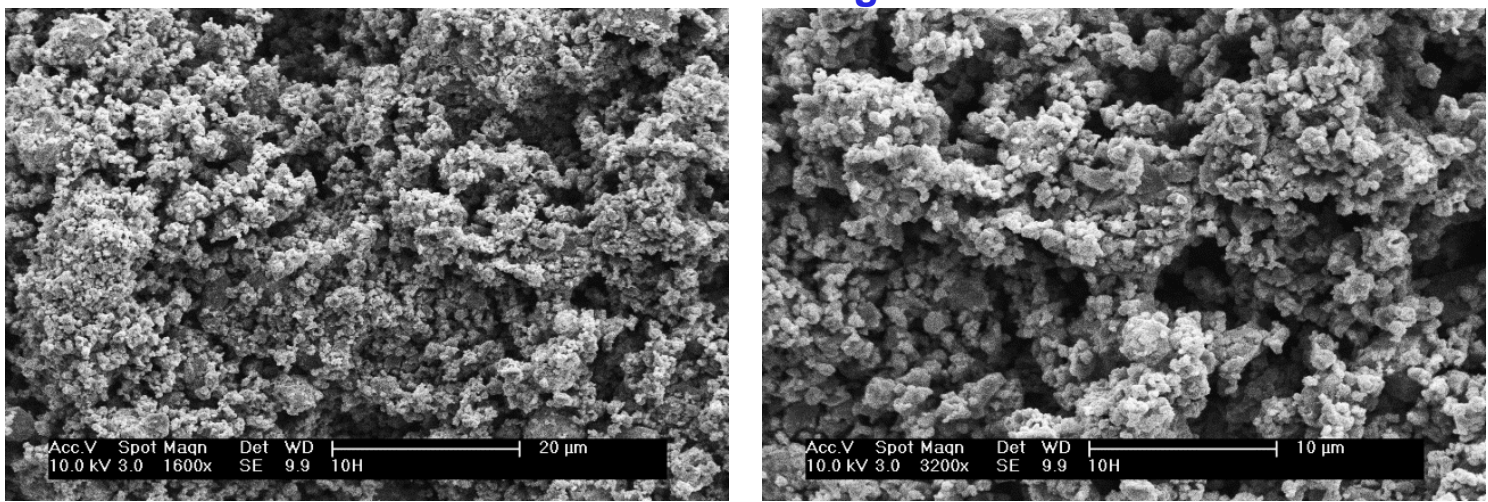

10 horas de moagem
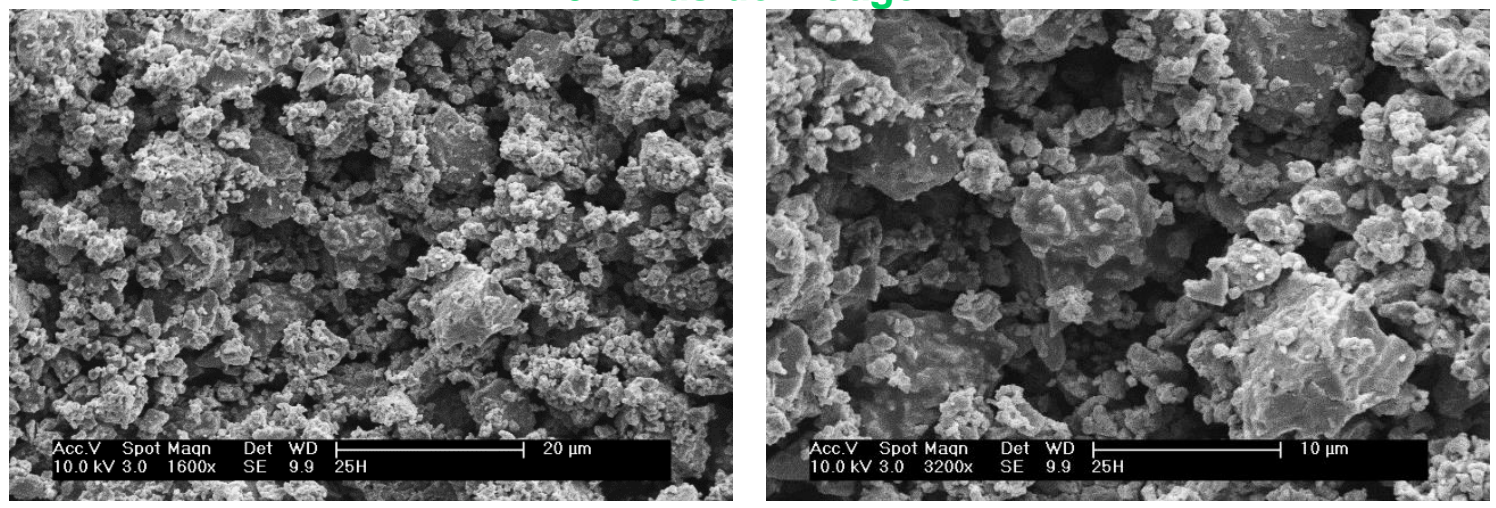

\section{5 horas de moagem}
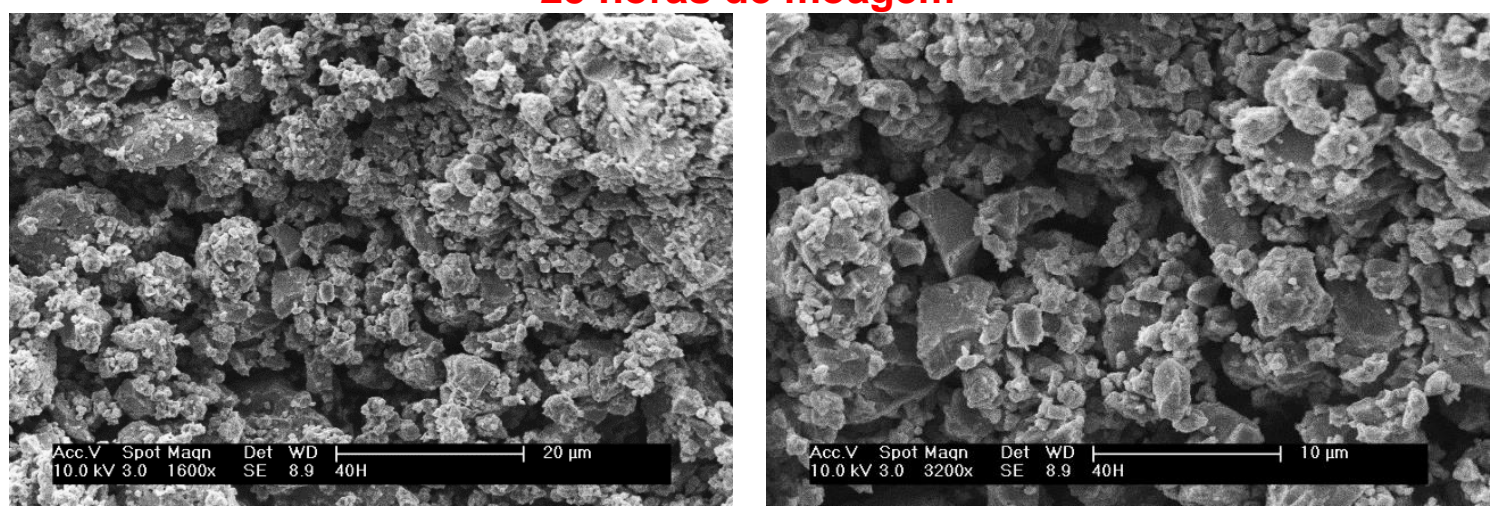

\section{0 horas de moagem}

FIGURA 31 - Micrografias de varredura de elétrons secundários (MEV) da forma dos agregados soltos após as moagens por deferentes tempos da composição 56:44. 


\subsection{Reação de síntese do composto TiFe}

No que concerne à investigação do processo de formação do TiFe, são apresentados na FIGURA 32 os termogramas referentes às análises por DSC e TG dos pós moídos por diferentes tempos do lote composicional 50:50. Nos termogramas oriundos das análises por DSC (FIGURA 32a), observam-se inicialmente dois picos endotérmicos, um menor em aproximadamente $230^{\circ} \mathrm{C}$, e outro maior próximo dos $425^{\circ} \mathrm{C}$, ambos atribuídos a decomposição do $\mathrm{TiH}_{2}$ em hidrogênio molecular e $\mathrm{Ti}$ livre $\left(\mathrm{TiH}_{2} \rightarrow \mathrm{Ti}+\mathrm{H}_{2}\right)$. Tal decomposição foi evidentemente acelerada pelo processo de moagem, resultado que fica evidente mediante a uma comparação direta com o termograma do pó de $\mathrm{TiH}_{2}$ não processado, apresentado na FIGURA 23. Nestes casos, a energia acumulada na forma de tensões estruturais teria catalisado a reação de decomposição do hidreto.

Após a decomposição do $\mathrm{TiH}_{2}$ (entre 230 e $425^{\circ} \mathrm{C}$ ), seguiram-se dois picos exotérmicos, um maior em aproximadamente $500^{\circ} \mathrm{C}$, e outro menor próximo dos $737^{\circ} \mathrm{C}$. O maior dos picos exotérmicos $\left(\sim 500^{\circ} \mathrm{C}\right)$ pode ser atribuído principalmente à formação do composto TiFe, que é acompanhada de um alívio de tensões internas e recuperação de defeitos da estrutura dos materiais moídos. Tal evento exotérmico parece ter ocorrido de forma intensa logo após a decomposição do $\mathrm{TiH}_{2}$, exceto no caso dos pós moídos por 5 horas, onde as reações de decomposição e formação parecem estar sobrepostas. Já o menor dos picos $\left(\sim 737^{\circ} \mathrm{C}\right)$ pode ser atribuído, segundo Novakova et al. (1998), à transformação de $\mathrm{TiFe}$ para $\mathrm{TiFe}_{2}\left(\mathrm{TiFe} \rightarrow \mathrm{TiFe}_{2}\right)$. Entretanto, como já havia sido observado anteriormente, o diagrama de fases do sistema Ti-Fe não apresenta tal transformação (ver FIGURA 6). Neste caso, a formação de um óxido de TiFe em um estágio intermediário da transformação seria a melhor explicação para tal fenômeno (ver as transformações indicadas na FIGURA 32a). Um mecanismo de transformação semelhante ao proposto também já havia sido observado por outros autores da literatura que estudaram a oxidação do sistema Ti-Fe [63, 64]. Tais resultados serão analisados ainda posteriormente com o auxílio das análises por DRX das amostras moídas e tratadas termicamente a diferentes temperaturas $\left(600\right.$ e $\left.800^{\circ} \mathrm{C}\right)$. 

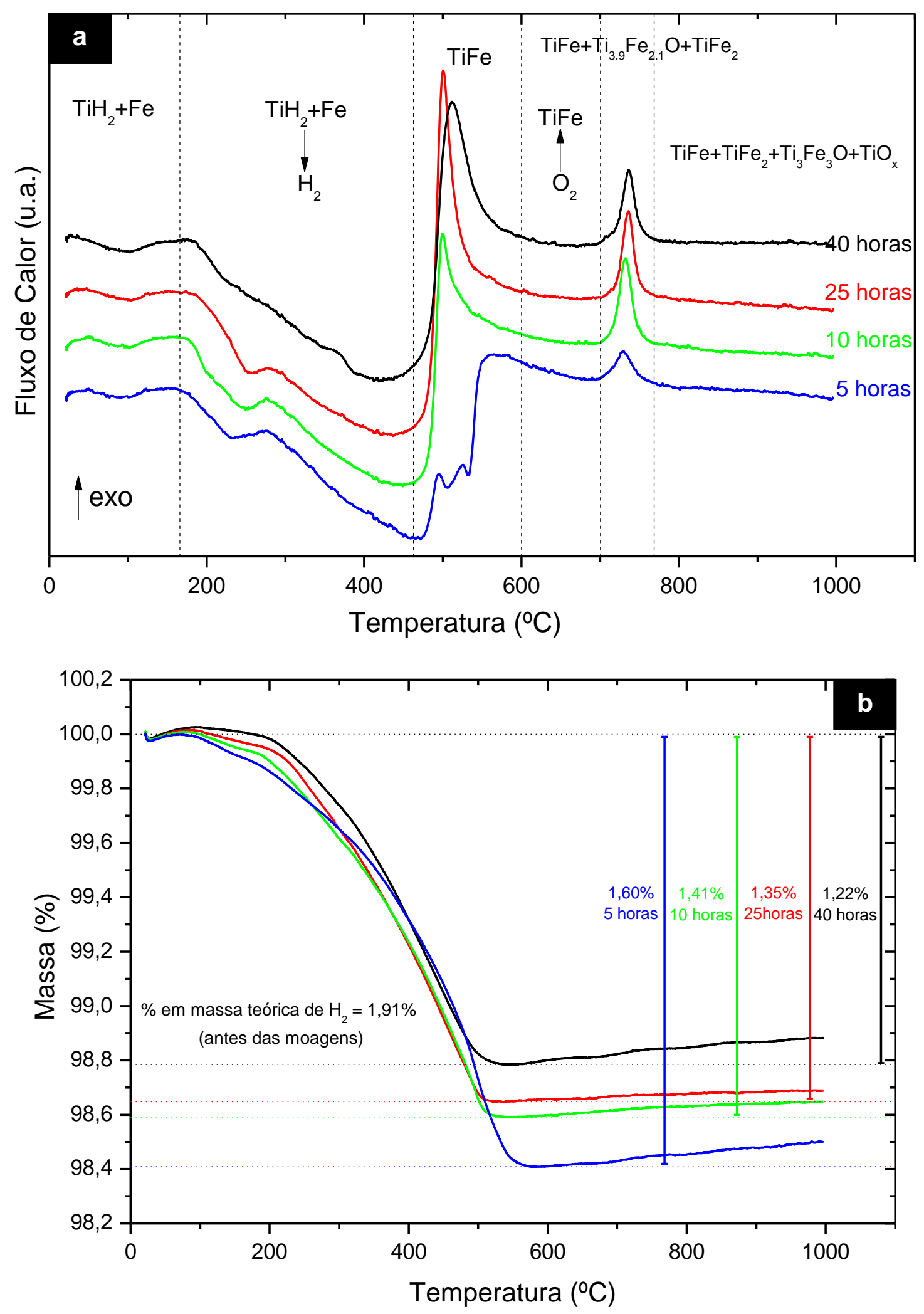

FIGURA 32 - Termogramas (DSC e TG) das amostras moídas por diferentes tempos da composição 50:50: (a) DSC; (b) TG. 
Já com relação às análises por TG, observa-se nos termogramas (FIGURA $32 b)$ uma maior perda de massa das amostras (em 230ํㅡ) em decorrência da liberação de hidrogênio molecular (gás), resultado que corrobora as observações já feitas com relação à decomposição do $\mathrm{TiH}_{2}$. Tais resultados corroboram ainda as observações anteriores com relação ao maior teor de solutos nas soluções ao longo do processo de moagem (e menor teor de $\mathrm{TiH}_{2}$ livre, ver FIGURA 25), evidenciado pela diminuição da porcentagem em massa de hidrogênio liberada ao longo das moagens (ver indicações da FIGURA 32b). Ainda nas análises por TG, também é possível observar nos termogramas um pequeno ganho de massa, principalmente a partir dos $650^{\circ} \mathrm{C}$, resultado possivelmente associado a uma maior oxidação superficial das amostras, e que vai ao encontro das observações já feitas com relação à oxidação do TiFe.

Os resultados obtidos nas análises por DSC e TG podem ser mais bem avaliados juntamente com os difratogramas obtidos após as reações de síntese do composto TiFe ( 600 e $800^{\circ} \mathrm{C}$ ), bem como com os resultados obtidos a partir dos refinamentos pelo método de Rietveld, apresentados na TABELA 8 (ver ajustes no APÊNDICE C).

Nos difratogramas referentes às amostras moídas e tratadas termicamente a $600^{\circ} \mathrm{C}$, apresentados na FIGURA 33 e FIGURA 34, constata-se que o TiFe é a fase majoritária ( $\geq 94,8 \%$ em massa) nas amostras moídas por maiores tempos (10, 25 e 40h). No caso das amostras moídas por menores tempos (5h), observase ainda a maior presença das fases $\mathrm{Fe}$ (até 18\% em massa) e de um óxido de $\mathrm{Ti}$ (possivelmente $\circ \mathrm{TiO}_{325} \mathrm{com}$ até $8 \%$ em massa), oxidação essa que pode ter ocorrido após as análises (exposição do material moído à atmosfera não controlada), ou mesmo durante o próprio tratamento térmico. Neste caso, como já havia sido observado nas micrografias da FIGURA 28 e FIGURA 29, o grau de dispersão gerado nas moagens parece não ter sido o suficiente para levar a completa formação do composto TiFe após os tratamentos térmicos, o que justifica a maior presença de Fe livre e do óxido de $\mathrm{Ti}\left(\mathrm{TiO}_{.325}\right)$. É importante observar também que, no caso das amostras da composição 56:44, mesmo nas moídas por maiores tempos, ainda podem ser encontradas porcentagens significativas do óxido de $\mathrm{Ti}$ (até 4,22\% em massa), resultado da maior porcentagem em massa de $\mathrm{Ti}$ adicionada a mistura para a posterior síntese do compósito $\mathrm{TiFe}-\mathrm{TiH}_{2}$ nos experimentos com hidrogênio. 

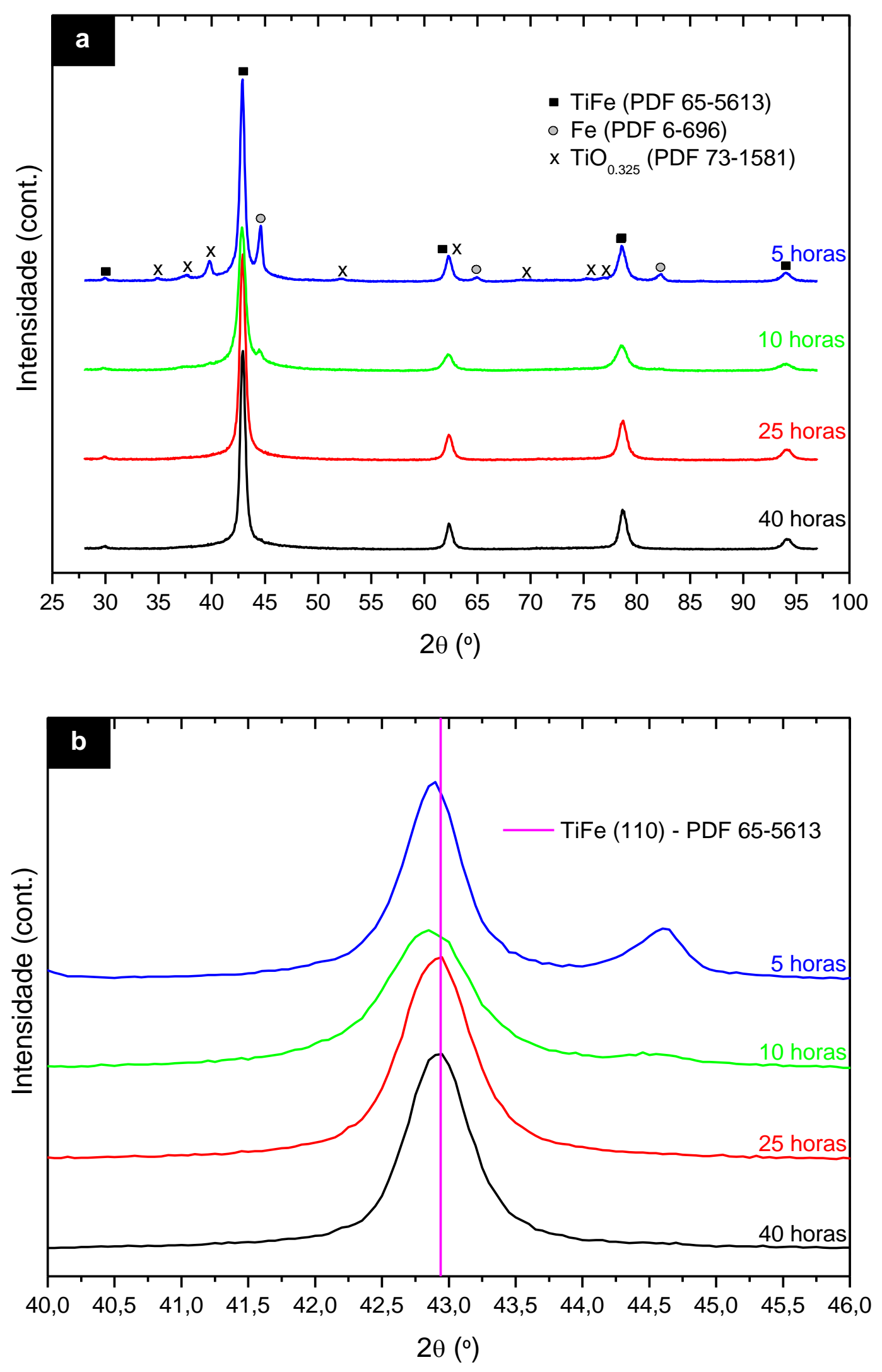

FIGURA 33 - Difratogramas de raios X (DRX) das amostras moídas por diferentes tempos e reagidas a $600^{\circ} \mathrm{C}$ da composição 50:50: Visão geral das fases presentes; (b) Visão expandida na região do pico (110) da fase TiFe. 

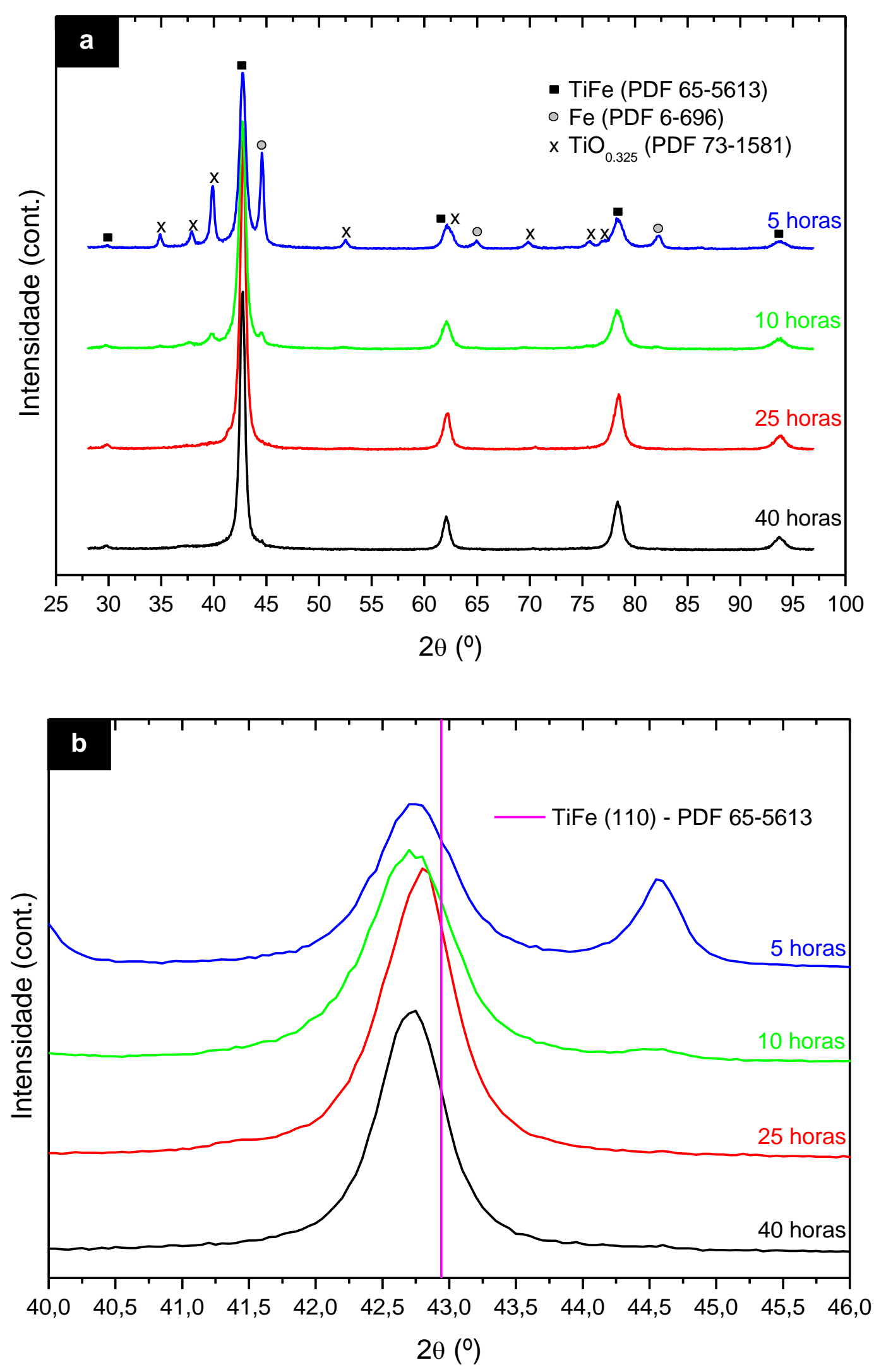

FIGURA 34 - Difratogramas de raios X (DRX) das amostras moídas por diferentes tempos e reagidas a $600^{\circ} \mathrm{C}$ da composição 56:44: Visão geral das fases presentes; (b) Visão expandida na região do pico (110) da fase TiFe. 

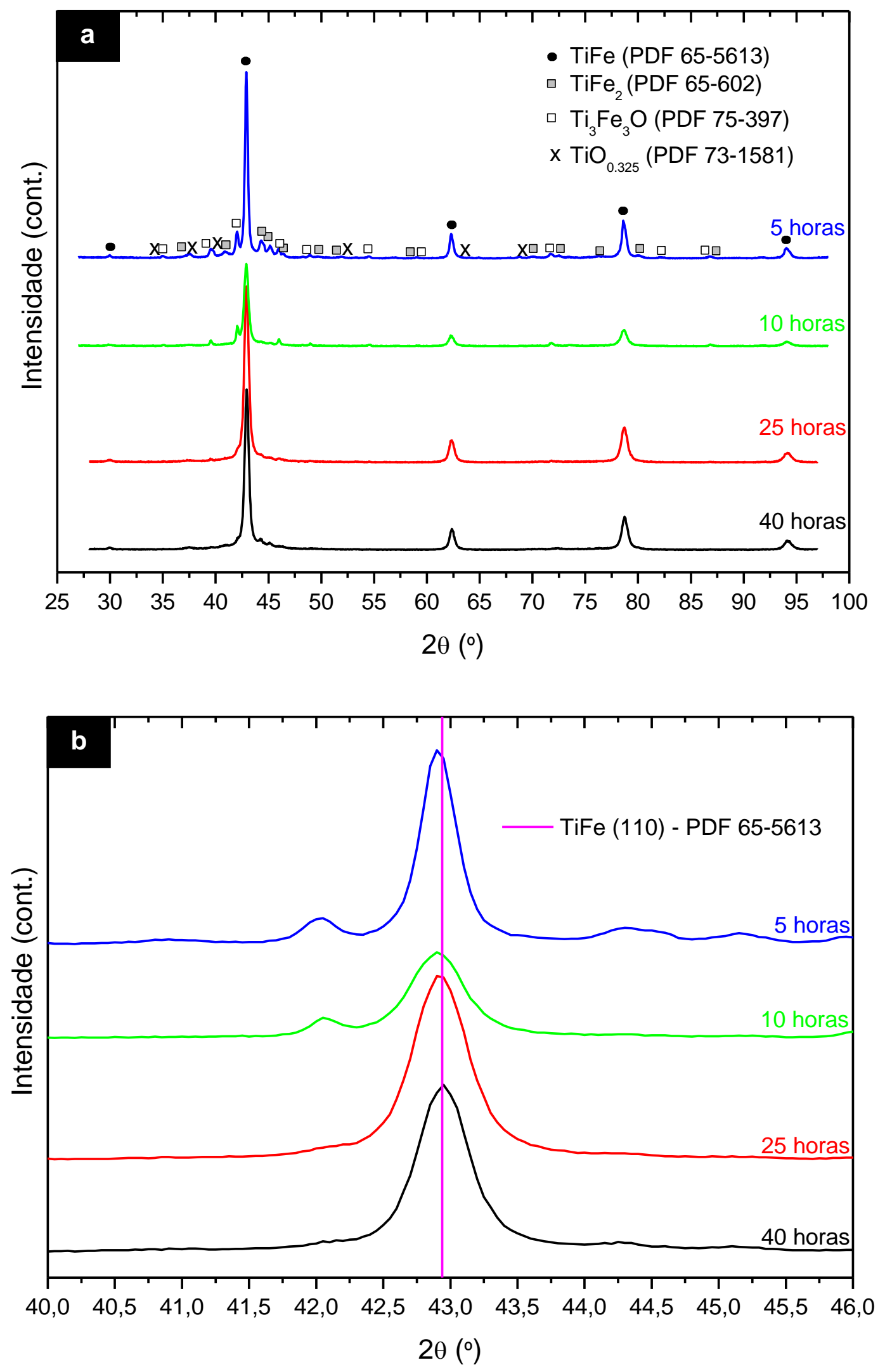

FIGURA 35 - Difratogramas de raios X (DRX) das amostras moídas por diferentes tempos e reagidas a $800^{\circ} \mathrm{C}$ da composição 50:50: (a) Visão geral das fases presentes; (b) Visão expandida na região do pico (110) da fase TiFe. 
TABELA 8 - Parâmetros microestruturais e composição de fases (\% em massa) das amostras moídas por diferentes tempos e reagidas a 600 e $800^{\circ} \mathrm{C}$ das composições 50:50 e 56:44.

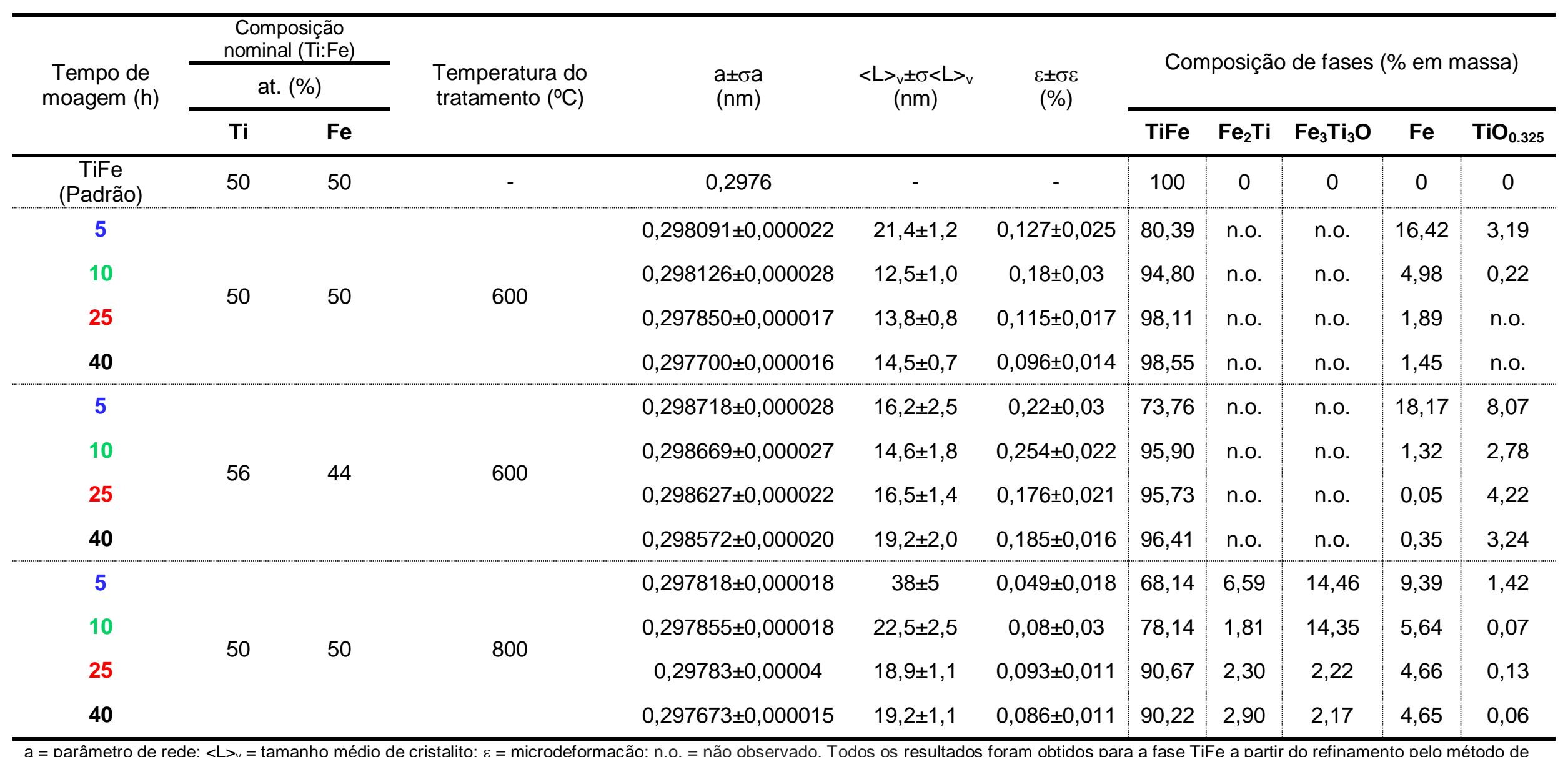


Ainda com relação aos difratogramas da FIGURA 33 e FIGURA 34, nota-se, em algumas das amostras, um sistemático deslocamento para a esquerda do pico (110) da fase TiFe, atribuído a maior formação da fase TiFe não estequiométrica (maior teor de Ti em solução sólida no TiFe), também representada por $\mathrm{TiFe}(\mathrm{Ti})$, resultados que se refletem na expansão da rede do TiFe em relação ao padrão (desvio nos parâmetros de rede de até 0,4\% em relação ao padrão, ver TABELA 8). Tal deslocamento parece variar com o tempo de moagem, bem como com a composição inicial utilizada nas moagens, resultado evidenciado nos parâmetros de rede da fase TiFe apresentados na FIGURA 37. A questão da variação composicional da fase TiFe já havia sido observada por diversos autores da literatura revisada, embora, em alguns casos, não tenha sido abordada de forma direta $[3,4,8,44$, $61,65]$.

No caso das amostras da composição 50:50, mais especificamente nas moagens por 5 e 10 horas, a expansão na rede do TiFe (desvio nos parâmetros de rede de até 0,2\% em relação ao padrão, ver TABELA 8) pode estar associada em boa parte aos diferentes graus de dispersão das fases $\mathrm{TiH}_{2}$ e Fe, que resultaram na formação de regiões mais ricas em Ti nas amostras. De fato, uma dispersão insuficiente destas fases nas amostras moídas poderia resultar, após os tratamentos térmicos, em um aumento do parâmetro de rede da fase TiFe, bem como das quantidades de Ti e Fe livres, caso observado nas amostras moídas por 5 e 10 horas. Por outro lado, com o aumento do grau de dispersão das fases $\mathrm{TiH}_{2}$ e $\mathrm{Fe}$, os valores do parâmetro de rede tenderiam a se aproximar aos da fase TiFe estequiométrica, caso observado nas amostras moídas por 25 e 40 horas (desvio nos parâmetros de rede menores que 0,08\% em relação ao padrão).

Já no caso das amostras da composição 56:44, além da questão dos diferentes graus de dispersão das fases $\mathrm{TiH}_{2}$ e $\mathrm{Fe}$, a adição de maiores porcentagens em massa de $\mathrm{TiH}_{2}$ na mistura também teve grande influência na variação composicional do TiFe (maior teor de solutos nas soluções), resultado que fica evidenciado pelo aumento dos parâmetros de rede do TiFe de todas as amostras desta composição (ver TABELA 8). A questão da variação composicional da fase TiFe pode ter grande influência sobre as propriedades de armazenamento de hidrogênio [44], e deve ainda ser avaliada 
posteriormente juntamente com os resultados para a absorção e dessorção de hidrogênio destas amostras.

Voltando aos difratogramas, na FIGURA 35, referente aos tratamentos térmicos a $800^{\circ} \mathrm{C}$ do lote 50:50, ainda se observa a presença majoritária da fase TiFe em todas as condições investigadas. Entretanto, fica evidente também a presença de segundas fases, como $\mathrm{TiFe}_{2}, \mathrm{Fe}_{3} \mathrm{Ti}_{3} \mathrm{O}$ e um óxido de $\mathrm{Ti}$ (possivelmente o $\mathrm{TiO}_{.325}$ ), principalmente nas amostras moídas por menores tempos. A formação destas segundas fases pode estar relacionada diretamente com o segundo pico exotérmico observado nas análises por DSC. Neste caso, o aumento da concentração de oxigênio no composto TiFe, observado nas análises por TG, teria levado a formação do composto $\mathrm{TiFe}_{2} \mathrm{e}$ de um óxido metaestável de TiFe $\left(\mathrm{Fe}_{3.9} \mathrm{Ti}_{2.1} \mathrm{O}_{0.96}\right)$, apresentado no diagrama de fases da FIGURA 36, que posteriormente se estabilizaria nos óxidos $\mathrm{Fe}_{3} \mathrm{Ti}_{3} \mathrm{O}$ e $\mathrm{TiO}_{x}$, resultados que se assemelham aos observados por autores como Schober (1983) e Davids e Lototskyy (2012), e corroboram as observações já feitas no presente trabalho com relação as análises por DSC e TG dos pós moídos.

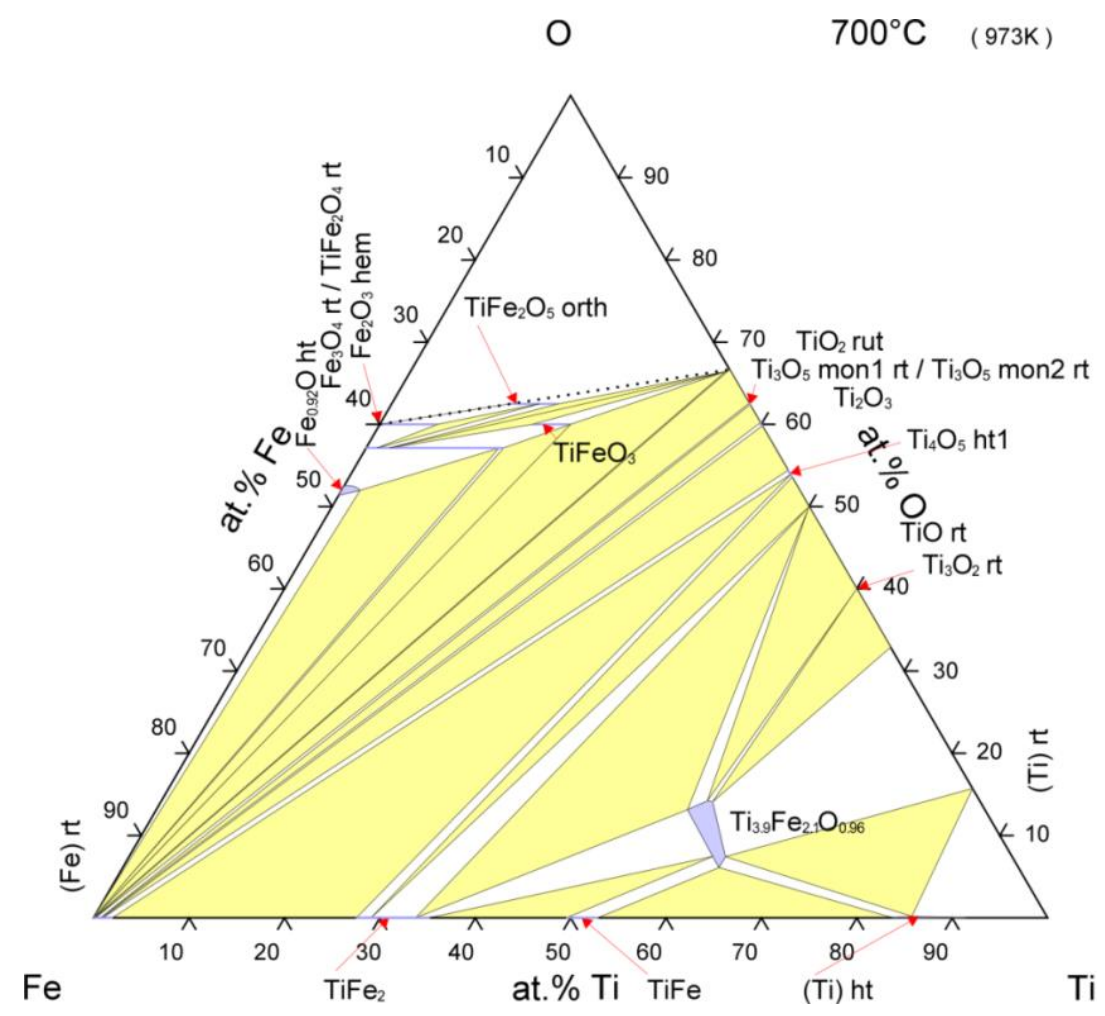

FIGURA 36 - Diagrama de fases do sistema Ti-O-Fe [82]. 
Outra questão relevante nos tratamentos térmicos a $800^{\circ} \mathrm{C}$ diz respeito à estabilidade das soluções sólidas $\mathrm{TiFe}(\mathrm{Ti})$. Aparentemente, como mostram os parâmetros de rede apresentados na FIGURA 37, tais soluções tendem a se desestabilizar com o aumento da temperatura, ou mesmo com o tempo de exposição à determinada temperatura, retornando a valores próximos aos da fase TiFe estequiométrica, resultados que corroboram as observações já feitas por autores como Zadorozhnyy et al. (2011). A partir dos resultados destas análises, foi estabelecida a temperatura máxima de $600^{\circ} \mathrm{C}$, e não menor do que $550^{\circ} \mathrm{C}$, para a reação de síntese do TiFe a ser utilizado nos experimentos com hidrogênio, devido principalmente a obtenção majoritária da fase TiFe sem a presença de uma oxidação significativa.

Ainda com relação à fase TiFe, também foram determinadas o tamanho médio de cristalito $(\langle L>v)$ e a microdeformação $(\varepsilon)$ das amostras reagidas das diferentes condições de moagem, cujos resultados são apresentados na TABELA 8 e nas curvas da FIGURA 37. Uma excelente revisão sobre a determinação destes parâmetros pelo método de Rietveld de refinamento pode ser encontrada na literatura pertinente [78]. Nas referidas curvas, em todos os casos investigados, é possível confirmar a formação do composto TiFe nanoestruturado (entre 12,5 e 38nm), característica esta já associada a uma melhora na difusão do hidrogênio para o interior do composto, assim como a uma redução na capacidade reversível de armazenamento em materiais que também apresentavam um maior grau de desordem estrutural [2, 4, 25, 44, 47]. Observa-se ainda que o tamanho médio de cristalito tende a aumentar quando são utilizadas maiores temperaturas nos tratamentos térmicos $\left(800^{\circ} \mathrm{C}\right)$ das amostras moídas (aumento de até $77 \%$ ), fenômeno associado ao crescimento de grãos [5]. Já dentro de um mesmo grupo de tratamentos (600ㄷ), não foram observadas grandes variações. Há que se evidenciar, todavia, certa tendência a um maior aumento do tamanho médio de cristalito nas amostras moídas e reagidas da composição 56:44 em relação as da composição 50:50, muito embora, todos estes valores ainda sejam compatíveis dentro do limite das incertezas apresentadas.

Diversos autores da literatura revisada também já haviam verificado, a partir de metodologia semelhante à empregada no presente trabalho (método de Rietveld de refinamento), a síntese do TiFe nanoestruturado após a 
moagem de alta energia, com valores entre aproximadamente 8 e $11 \mathrm{~nm}[5,61]$. Nesta última referência, em especial, onde os materiais moídos também foram submetidos a tratamentos térmicos $\left(600^{\circ} \mathrm{C}\right)$, os autores observaram tamanhos médios de cristalito entre 12 e $14 \mathrm{~nm}$, resultados compatíveis com os determinados em condições semelhantes no presente trabalho (entre 12,5 e 21,4nm). A síntese do TiFe nanoestruturado também foi confirmada por MET em diversos casos da literatura revisada, tendo sido apresentados comumente valores entre 5 e $10 \mathrm{~nm}$. Tais valores vão ao encontro dos tamanhos de cristalito observados nas micrografias apresentadas na FIGURA 38 (entre 7 e $10 \mathrm{~nm}$ ), bem como com os já observados pela difração de raios $X$ das amostras moídas na mesma condição (entre 12,5 e 14,2nm, respectivamente para 10 e 40h de moagem).

Já no caso das microdeformações, o aumento da temperatura dos tratamentos teve um efeito inverso, reduzindo estes valores (redução de até $55 \%$ ), fenômeno associado a um alívio das tensões internas da estrutura do $\mathrm{TiFe}$, assim como com a recuperação de seus defeitos. Outro aspecto curioso observado nestas análises foi a tendência apresentada por algumas amostras em manter um maior grau de microdeformação após os tratamentos térmicos a $600^{\circ} \mathrm{C}$, sendo estes valores tão maiores quanto as porcentagens de $\mathrm{Ti}$ em solução no TiFe, bem como com as de Ti livre.

A questão da microdeformação, assim como a do tamanho médio de cristalito, pode ter grande influência sobre as propriedades de armazenamento de hidrogênio, portanto, ainda deve ser avaliada cuidadosamente em conjunto com os resultados obtidos a partir dos experimentos com hidrogênio. 

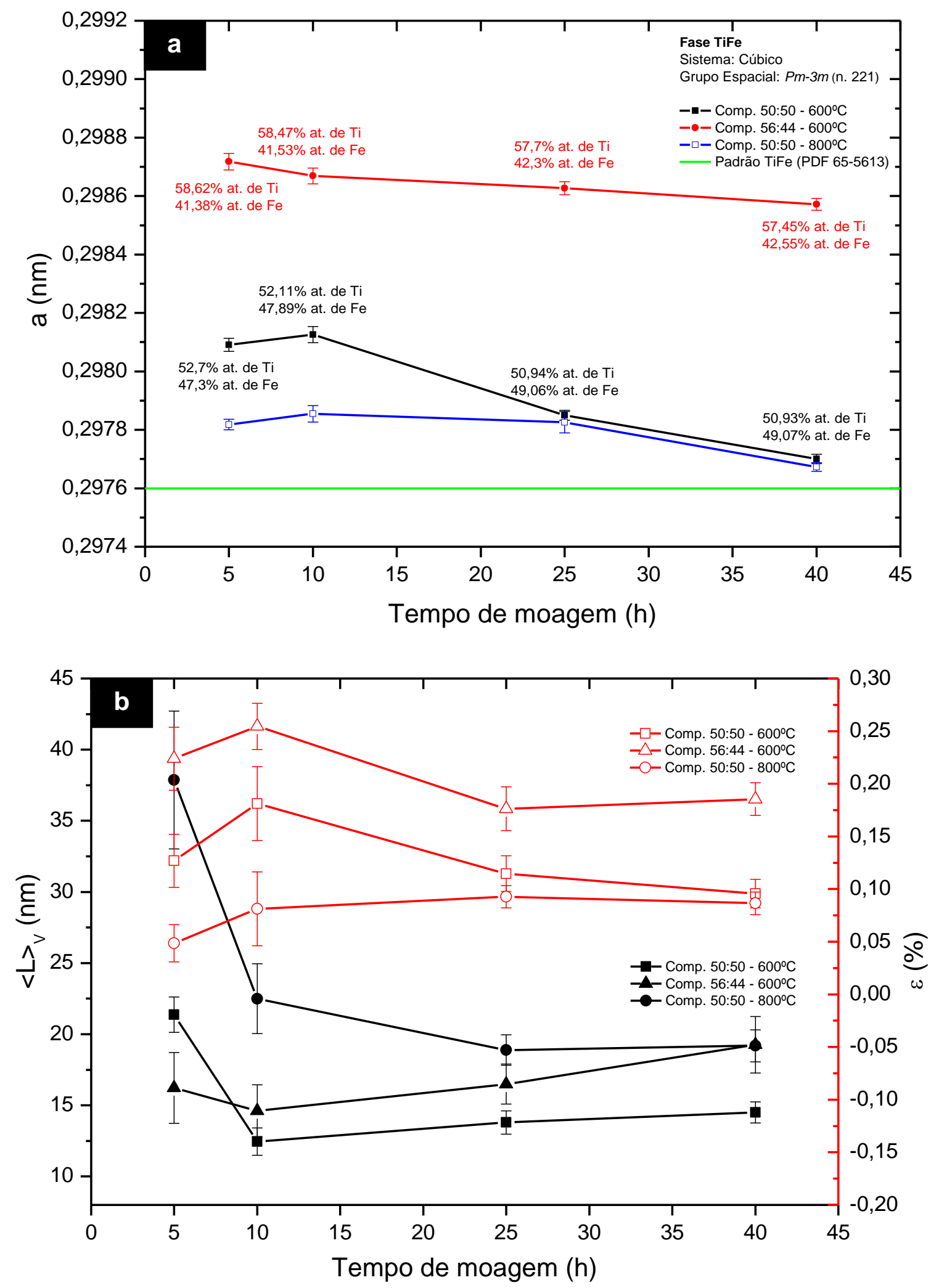

FIGURA 37 - (a) Parâmetros de rede, além do detalhe das porcentagens atômicas de $\mathrm{Ti}$ e $\mathrm{Fe}$; (b) tamanho médio de cristalito $\left.(<L\rangle_{v}\right)$ e microdeformação $(\varepsilon)$ da fase TiFe das amostras moídas por diferentes tempos e reagidas a $600 \mathrm{e}$ $800^{\circ} \mathrm{C}$ das composições 50:50 e 56:44. 

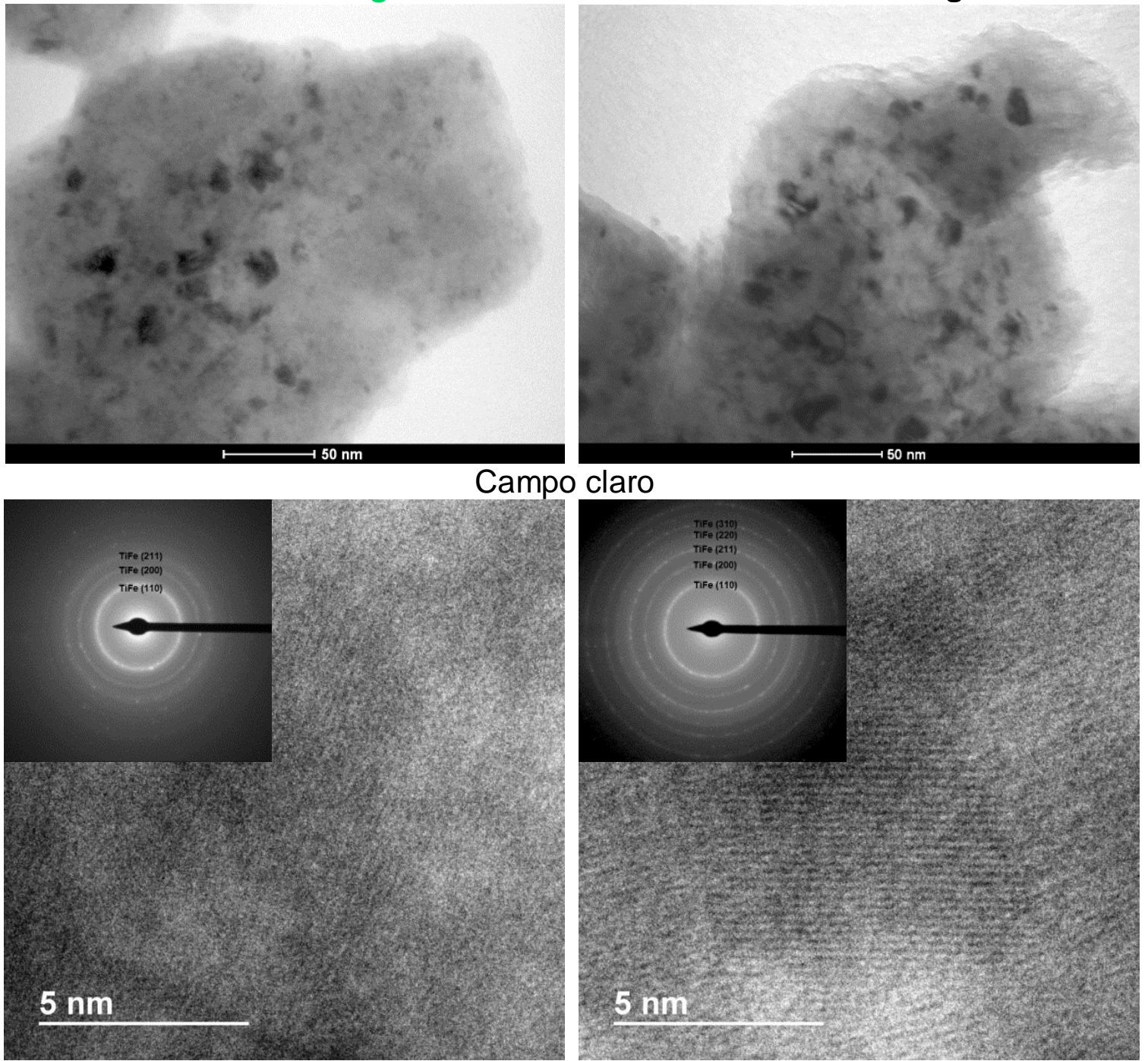

Alta resolução

FIGURA 38 - Micrografias de elétrons transmitidos (MET) das amostras moídas por 10 e 40 horas e reagidas a $600^{\circ} \mathrm{C}$ da composição 50:50, além do detalhe do padrão de difração de elétrons da fase TiFe.

\subsection{Estudo das propriedades de armazenamento de hidrogênio do TiFe}

Antes de dar início aos experimentos com hidrogênio, novas amostras das diferentes condições de moagem foram reagidas utilizando os mesmos procedimentos estabelecidos nos itens anteriores (aquecimento até $600^{\circ} \mathrm{C}$ sob vácuo dinâmico, sem patamar). Após a reação de síntese do composto TiFe, as amostras foram resfriadas, a partir da temperatura de síntese ( 600ํ) até a temperatura ambiente $\left(\sim 25^{\circ} \mathrm{C}\right)$, sob pressão de hidrogênio de aproximadamente 21bar (as amostras permaneceram sob está pressão por 10min. antes do início do resfriamento), procedimento que resultou na síntese 
do compósito $\mathrm{TiFe}^{-\mathrm{TiH}_{2}}$ (nas amostras com excesso de $\mathrm{Ti}$ livre). Tais resultados podem ser verificados nos difratogramas obtidos após o ciclo de hidretação das amostras (FIGURA 39 e FIGURA 40), assim como nos resultados obtidos a partir dos refinamentos pelo método de Rietveld, apresentados na TABELA 9 (ver ajustes no APÊNDICE C).

A primeira absorção de hidrogênio das amostras durante o resfriamento pode ser verificada nas curvas da diferença de pressão do equipamento (ver APÊNDICE B), apresentadas na FIGURA 42. Nestas curvas, observa-se que todas as amostras, independente do tempo de moagem e da composição inicial, absorveram quantidades significativas de hidrogênio, evidência clara de que estas ainda estavam ativas após as reações de síntese. A manutenção desta atividade está relacionada ao fato da primeira absorção de hidrogênio ter sido realizada in situ (no mesmo local onde as amostras foram reagidas), ou mesmo com a variação composicional das fases TiFe e a maior porcentagem em massa de $\mathrm{TiH}_{2}$ livre nas amostras, algo que já havia sido abordado em algumas das referências revisadas [3, 4, 6, 61, 67, 73, 75, 83].

Já com relação às diferentes temperaturas de absorção observadas (entre 40 e $87^{\circ} \mathrm{C}$ ), nota-se no caso da amostra moída por 10 horas do lote composicional 50:50, assim como nas amostras moídas por 10, 25 e 40 horas da composição 56:44, que as absorções ocorreram sempre a partir de maiores temperaturas $\left(>80^{\circ} \mathrm{C}\right)$, um indicativo de que o hidrogênio podia se dissociar e penetrar mais facilmente na superfície destas amostras, antecipando assim a formação da fase hidreto em relação as demais (5, 25 e 40h da composição 50:50 e $5 \mathrm{~h}$ da composição 56:44), resultado que possivelmente deve se refletir em platôs de pressão de absorção de hidrogênio relativamente mais baixos. A origem de tal fenômeno parece estar intimamente ligada à variação composicional da fase TiFe (maior teor de Ti em solução sólida no TiFe), assim como com os possíveis caminhos gerados (limpos e reativos) pela expansão volumétrica do Ti livre ao ser hidretado (até $17 \%$ de expansão volumétrica), resultados estes sempre acompanhados pelo aumento das microdeformações da fase TiFe (ver TABELA 9) [44, 75, 84]. Contudo, especialmente no caso das amostras moídas por 5 horas de ambos os lotes, que apresentavam características semelhantes às referidas, a magnitude deste fenômeno parece ter sido diminuta. Tais resultados podem indicar uma dependência deste 
fenômeno com o grau de dispersão do Ti livre (antes da hidretação), ou mesmo com a desestabilização das soluções $\mathrm{TiFe}(\mathrm{Ti})$ durante o período em que as amostras ficaram expostas a elevadas temperaturas e pressão de hidrogênio (600ํ $\mathrm{C}$ e 21 bar, respectivamente) $[5,75]$.

Ainda com relação às curvas de absorção, verificam-se diferentes formas de queda ao longo dos resfriamentos, fenômeno associado provavelmente as diferentes taxas de absorção de hidrogênio das amostras. No caso onde se observam as quedas mais acentuadas, 10 horas da composição 50:50 e 25 e 40 horas da composição 56:44, as curvas parecem acompanhar o mesmo fenômeno já observado nas temperaturas, um indicativo de que esse poderia estar ligado não só a uma maior facilidade de dissociação e penetração de hidrogênio nas amostras, mas também a um aumento de suas taxas (melhor cinética de absorção), isto claro, quando sob pressões de hidrogênio aproximadamente equivalentes. Contudo, como mostram as curvas das amostras moídas por 5 horas do lote 50:50 e por 5 e 10 horas do lote 56:44, que apresentavam características semelhantes às referidas (maior teor de Ti em solução sólida no TiFe e de Ti livre na forma de hidreto), esta queda não foi tão acentuada. Aventase então a possibilidade de que as taxas de absorção de hidrogênio estejam relacionadas ainda a outras características dessas amostras, como os maiores tamanhos médios de cristalito (redução das taxas de difusão), as menores porcentagens da fase TiFe nas amostras (menor número de sítios ativos para a nucleação da fase hidreto, ver TABELA 9), ou mesmo a já relatada desestabilização das soluções $\mathrm{TiFe}(\mathrm{Ti})$, questões que podem ser mais bem avaliadas nas curvas da FIGURA 41.

Todas as características destacadas até 0 presente momento, especialmente no caso das moagens por 10 horas do lote 50:50 e por 25 e 40 horas do lote 56:44, parecem de maneira geral ter influenciado mais positivamente as propriedades de armazenamento de hidrogênio. Contudo, muitas destas características podem ter uma influência ambígua sobre as propriedades de armazenagem, devendo ser avaliadas de forma mais concreta em conjunto com as estimativas de hidrogênio residual após o completo ciclo de hidretação das amostras. 

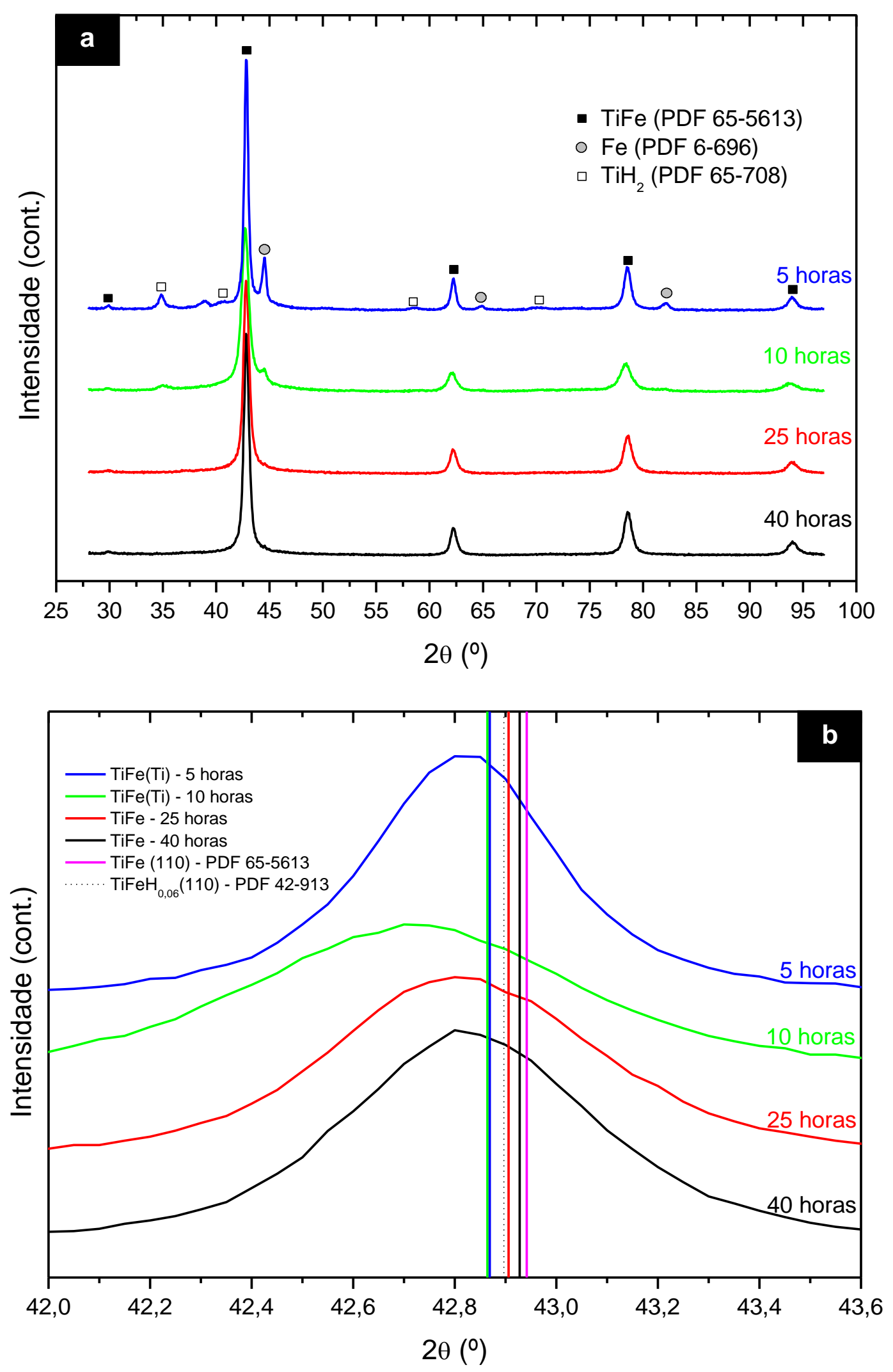

FIGURA 39 - Difratogramas de raios X (DRX) das amostras moídas por diferentes tempos e reagidas a 600들 da composição 50:50 após o clico de hidretação: (a) Visão geral das fases presentes; (b) Visão expandida na região do pico (110) da fase TiFe. 

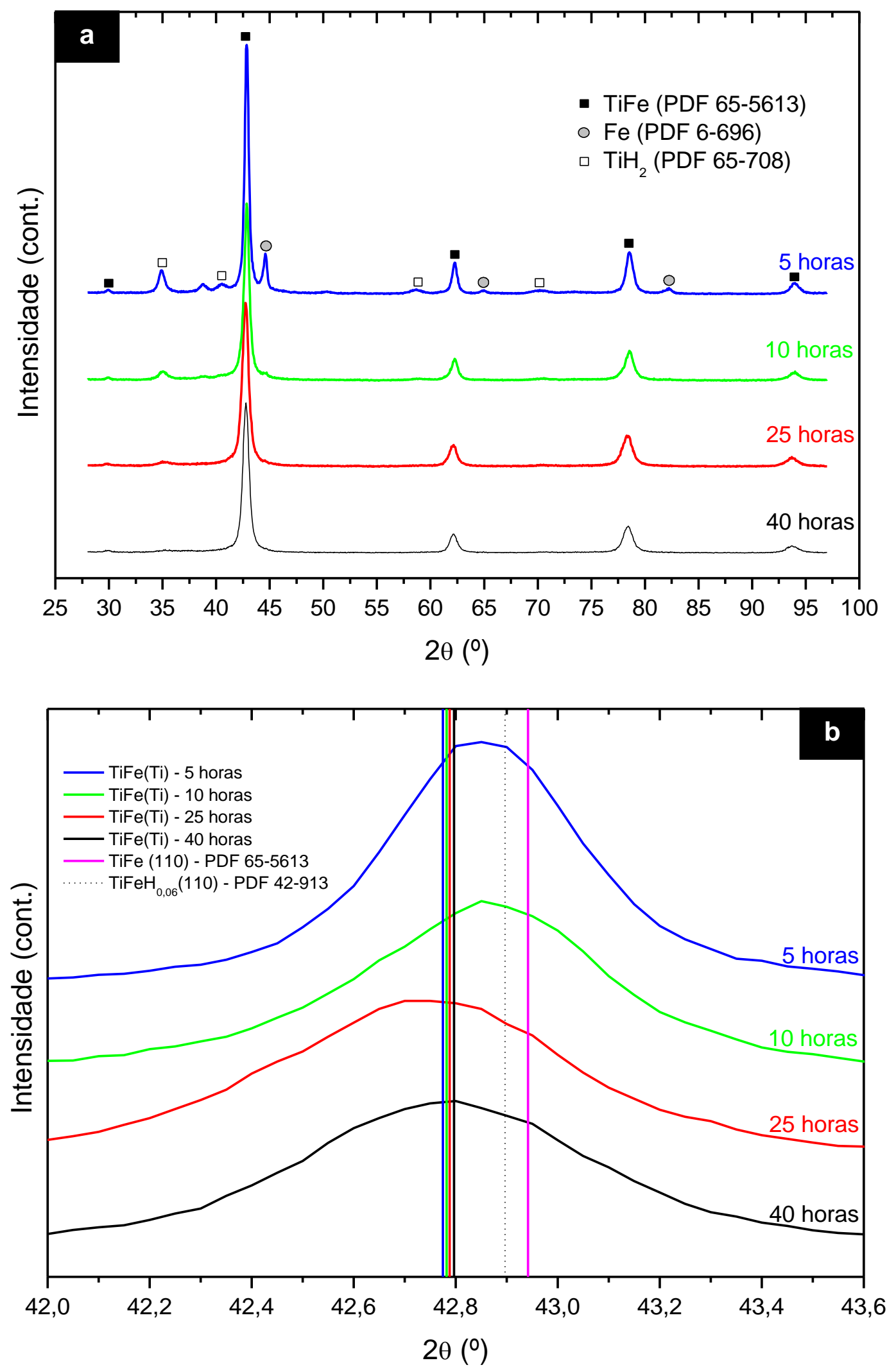

FIGURA 40 - Difratogramas de raios X (DRX) das amostras moídas por diferentes tempos e reagidas a $600^{\circ} \mathrm{C}$ da composição 56:44 após o clico de hidretação: (a) Visão geral das fases presentes; (b) Visão expandida na região do pico (110) da fase TiFe. 
TABELA 9 - Parâmetros microestruturais e composição de fases (\% em massa) das amostras moídas por diferentes tempos e reagidas a $600^{\circ} \mathrm{C}$ das composições 50:50 e 56:44 após o ciclo de hidretação.

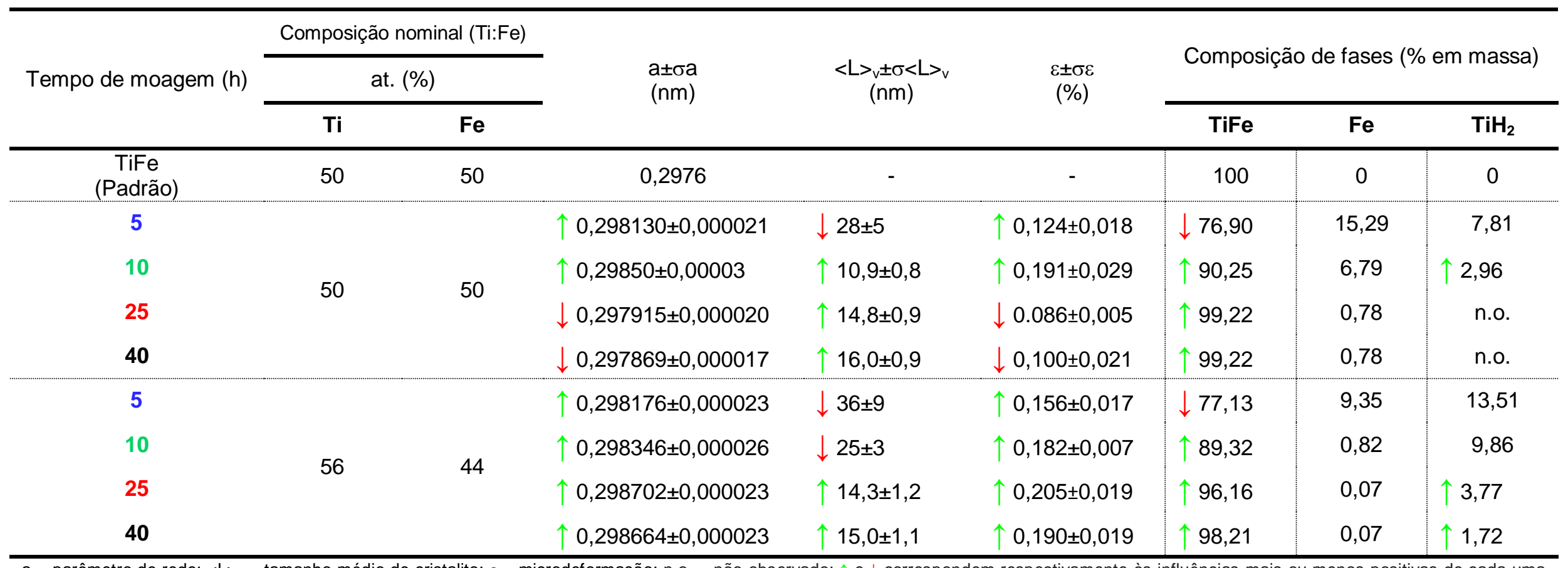

$\mathrm{a}=$ parâmetro de rede; $\left\langle\mathrm{L}_{\mathrm{v}}=\right.$ tamanho médio de cristalito; $\varepsilon=$ microdeformação; $n .0$. = não observado; $\uparrow$ e $\downarrow$ correspondem respectivamente às influências mais ou menos positivas de cada uma das características selecionadas sobre as propriedades de armazenamento de hidrogênio das amostras. Todos os resultados foram obtidos para a fase TiFe a partir do refinamento pelo método de Rietveld. 

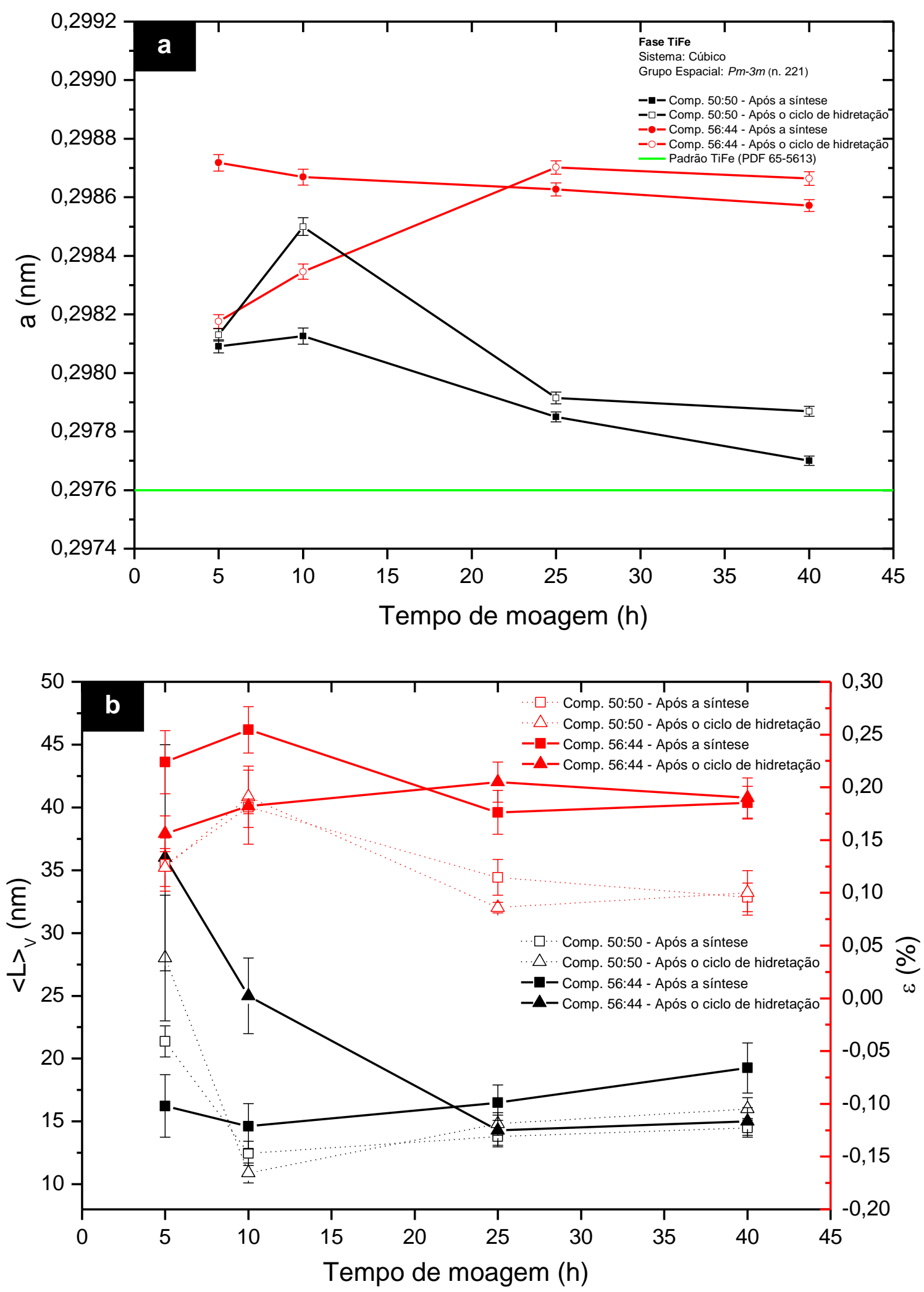

FIGURA 41 - (a) Parâmetros de rede; (b) tamanho médio de cristalito $(<L>v)$ e microdeformação $(\varepsilon)$ da fase TiFe das amostras moídas por diferentes tempos e reagidas a $600^{\circ} \mathrm{C}$ das composições 50:50 e 56:44 após o ciclo de hidretação. 

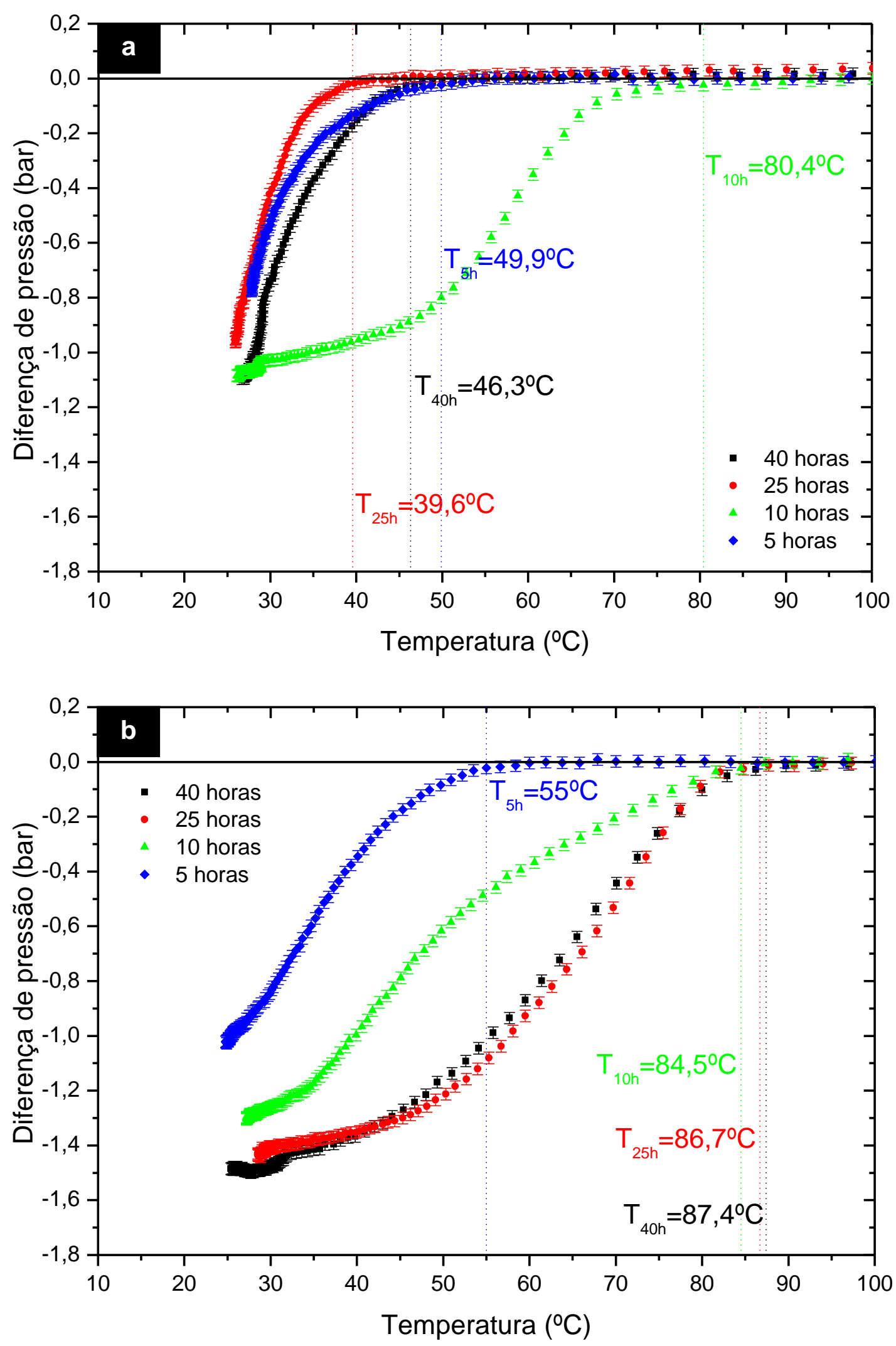

FIGURA 42 - Diferença de pressão do equipamento ao longo do resfriamento das amostras moídas e reagidas a $600^{\circ} \mathrm{C}$ das composições: (a) 50:50; (b) $56: 44$. 
Depois de constatada a primeira absorção de hidrogênio, iniciaram-se os experimentos para um estudo mais detalhado das propriedades de armazenagem das amostras reagidas dos lotes composicionais 50:50 e 56:44. Para tal fim, foram realizadas rotinas de despressurização e pressurização do equipamento Sievert, entre 1 e $21 \mathrm{bar}$, a temperaturas próximas a da ambiente $\left(\sim 25^{\circ} \mathrm{C}\right)$, completando assim o ciclo de hidretação das amostras. Vale relembrar que o termo ciclo de hidretação se refere à sequência de primeira absorção (sem quantificação de hidrogênio) $\rightarrow$ dessorção (rotina de despressurização do equipamento) $\rightarrow$ absorção (rotina de pressurização do equipamento).

Após a realização das rotinas, a partir dos dados fornecidos pelo equipamento, foram levantadas as curvas apresentadas na FIGURA 43 e FIGURA 44, além das curvas PCTs, apresentadas na FIGURA 45 e FIGURA 46 (ver metodologia empregada no APÊNDICE B), cujos principais resultados estão sintetizados na TABELA 10 até a TABELA 13. É importante salientar que, devido a alta frequência de aquisição de dados utilizada nos experimentos ( $f=1 / 10 \mathrm{~s}$ ), as curvas foram plotadas com 1 a cada 20 (ou 30 ) dados fornecidos pelo equipamento, facilitando assim a visualização dos resultados.

Nas curvas da FIGURA 43 e FIGURA 44, nota-se um comportamento crescente da pressão do equipamento em função do tempo, atribuído à dessorção de hidrogênio pela amostra (extinção sequencial das fases $\beta \rightarrow \beta+\alpha \rightarrow \alpha$, ver TABELA 10 até a TABELA 13). Ainda nestas curvas, observa-se também o comportamento inverso, atribuído a absorção de hidrogênio pela amostra (formação sequencial das fases $\alpha \rightarrow \beta+\alpha \rightarrow \beta$, ver TABELA 10 até a TABELA 13). Em alguns casos, basicamente nos trechos de formação do hidreto $(\beta+\alpha)$, é possível verificar uma leve mudança nas linhas base de ajuste, resultado provavelmente relacionado à maior extensão dos platôs de pressão, e por consequência das condições de sobrepressão nas amostras que apresentavam diminutas taxas de absorção. 
Dessorção de $\mathrm{H}_{2}$

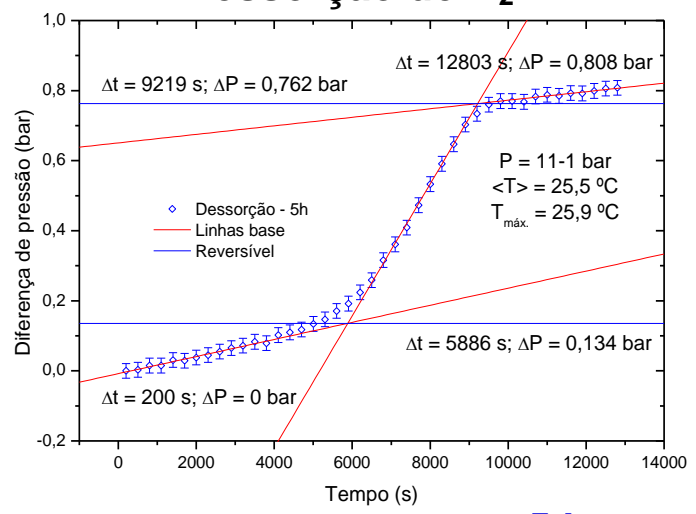

5 horas de moagem
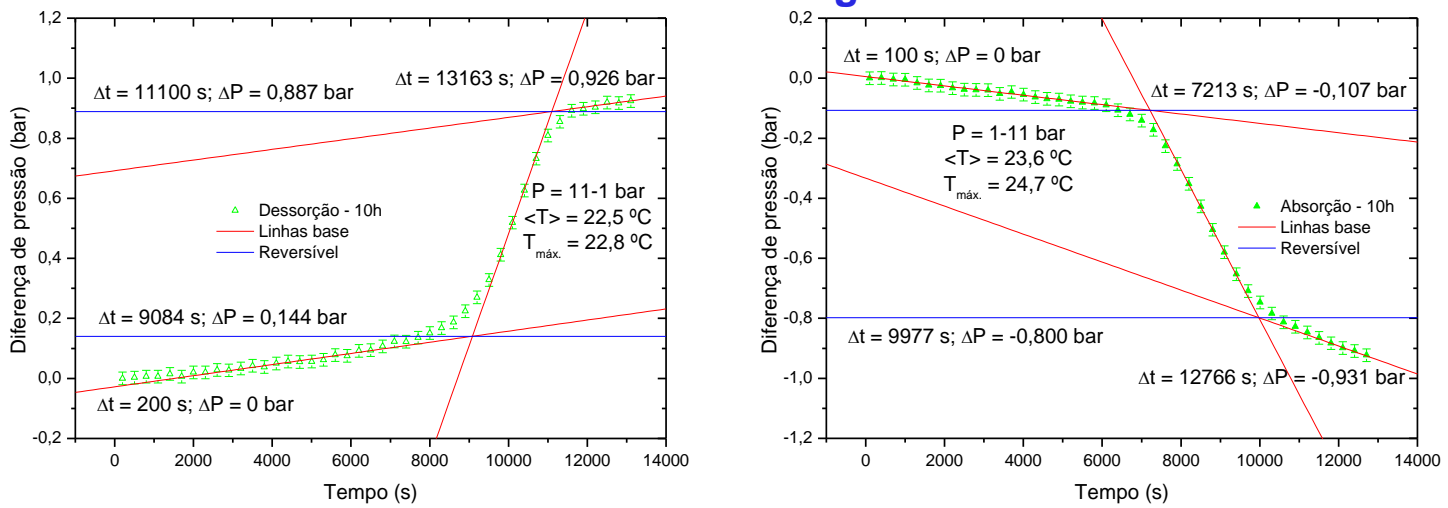

10 horas de moagem
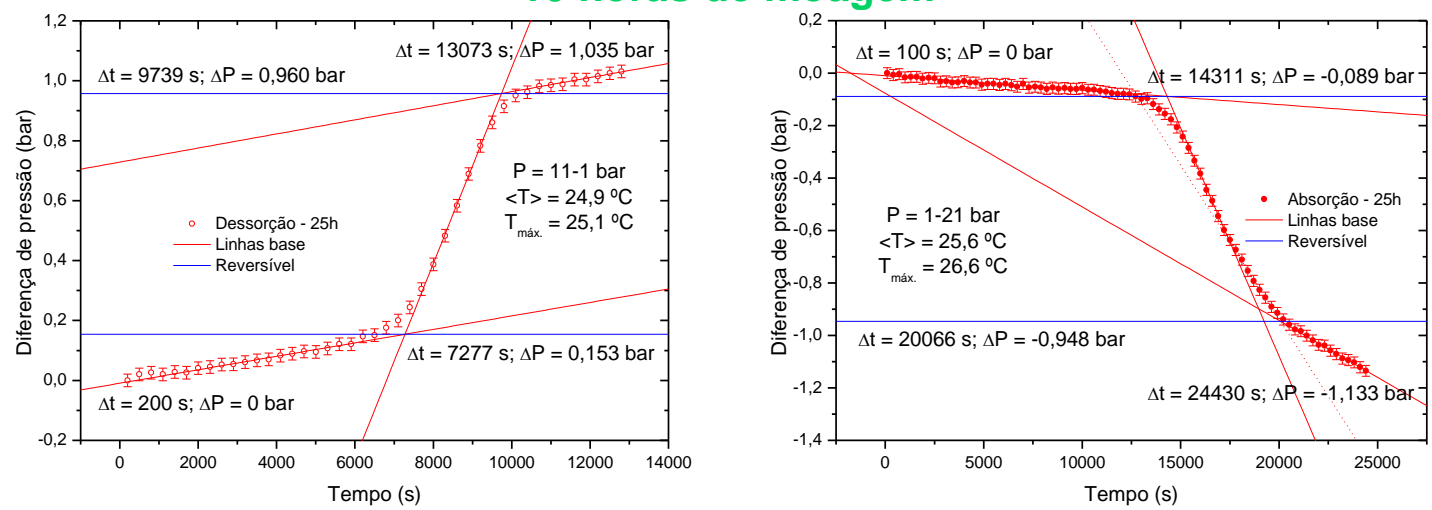

25 horas de moagem
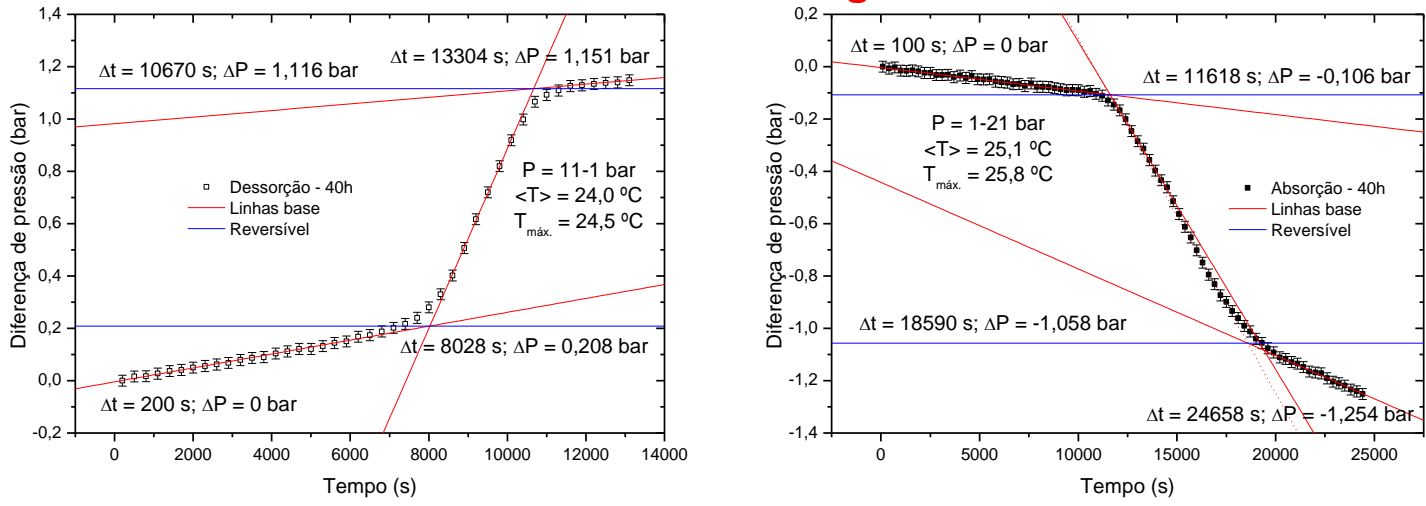

40 horas de moagem

FIGURA 43 - Diferença de pressão do equipamento em função do tempo para a dessorção e absorção de hidrogênio das amostras moídas por diferentes tempos e reagidas a $600^{\circ} \mathrm{C}$ da composição 50:50. 
Dessorção de $\mathrm{H}_{2}$

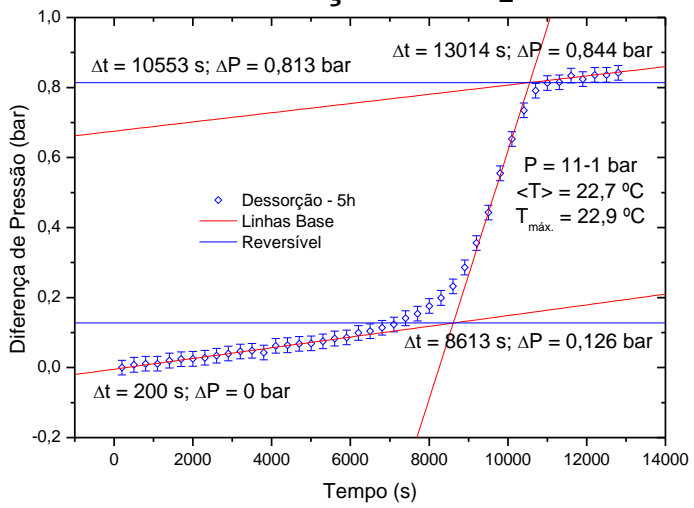

Absorção de $\mathrm{H}_{2}$

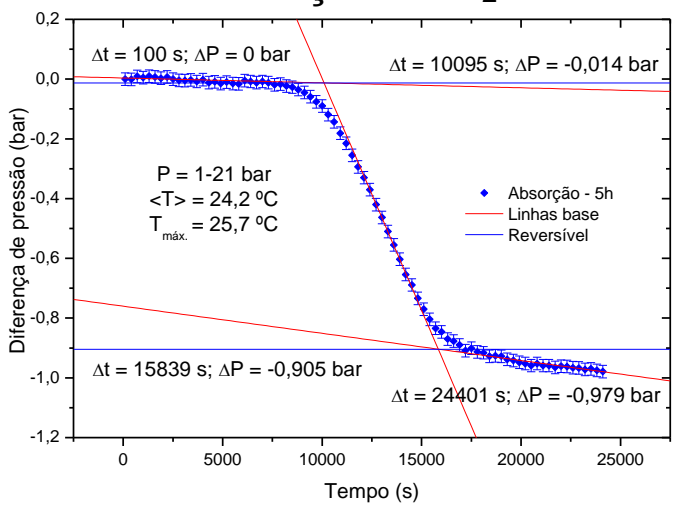

5 horas de moagem
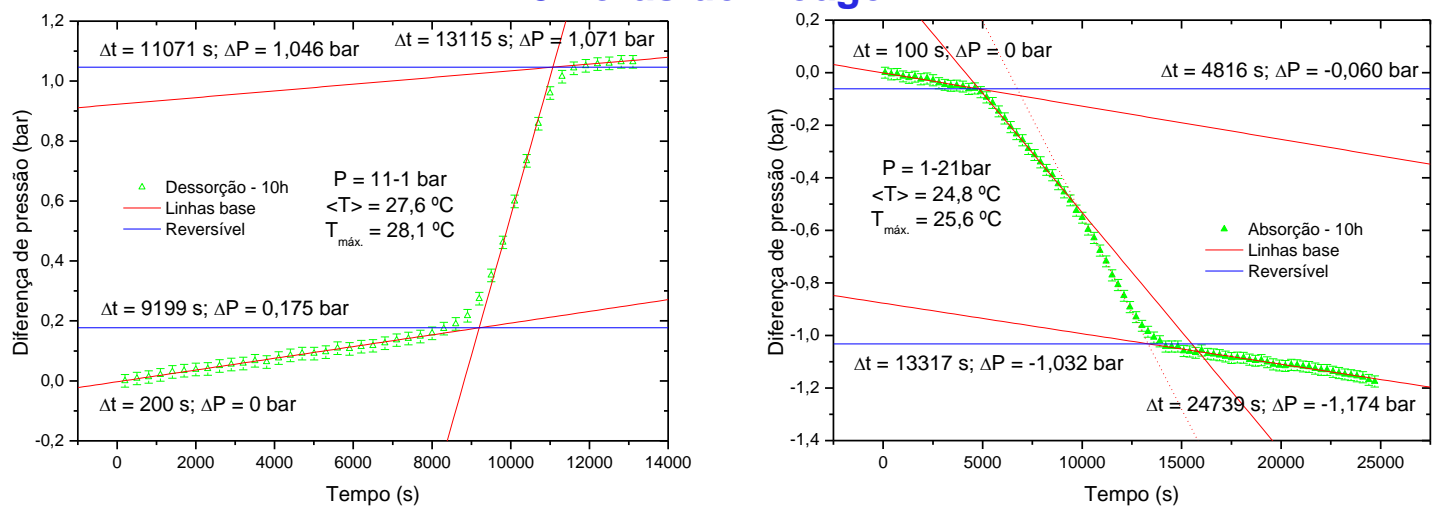

10 horas de moagem
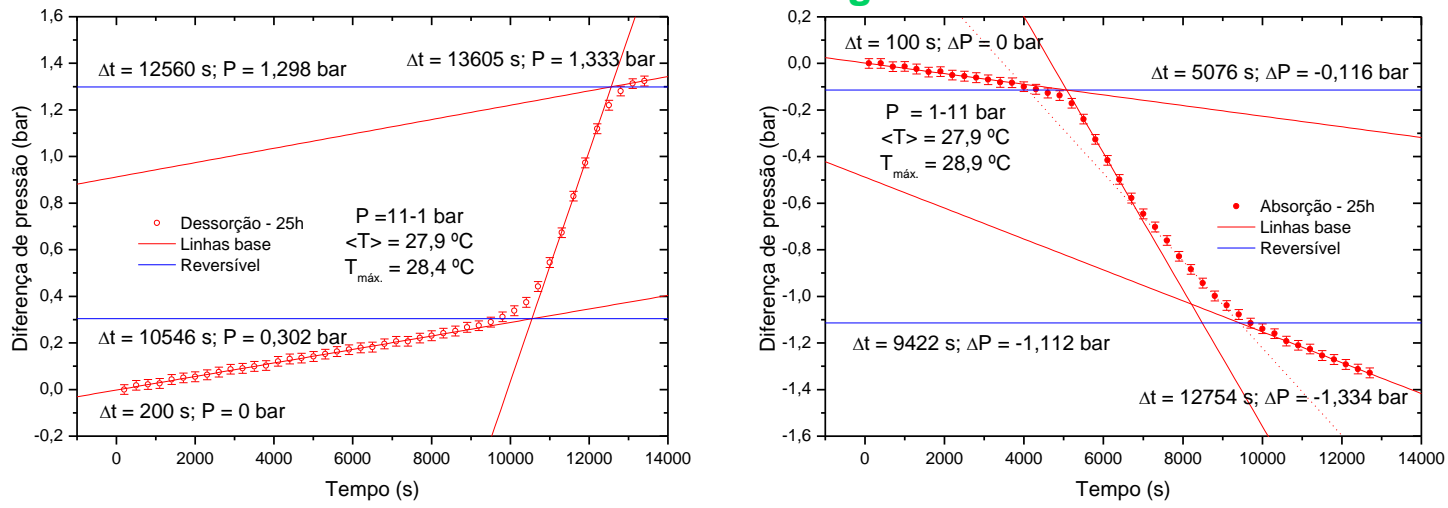

25 horas de moagem
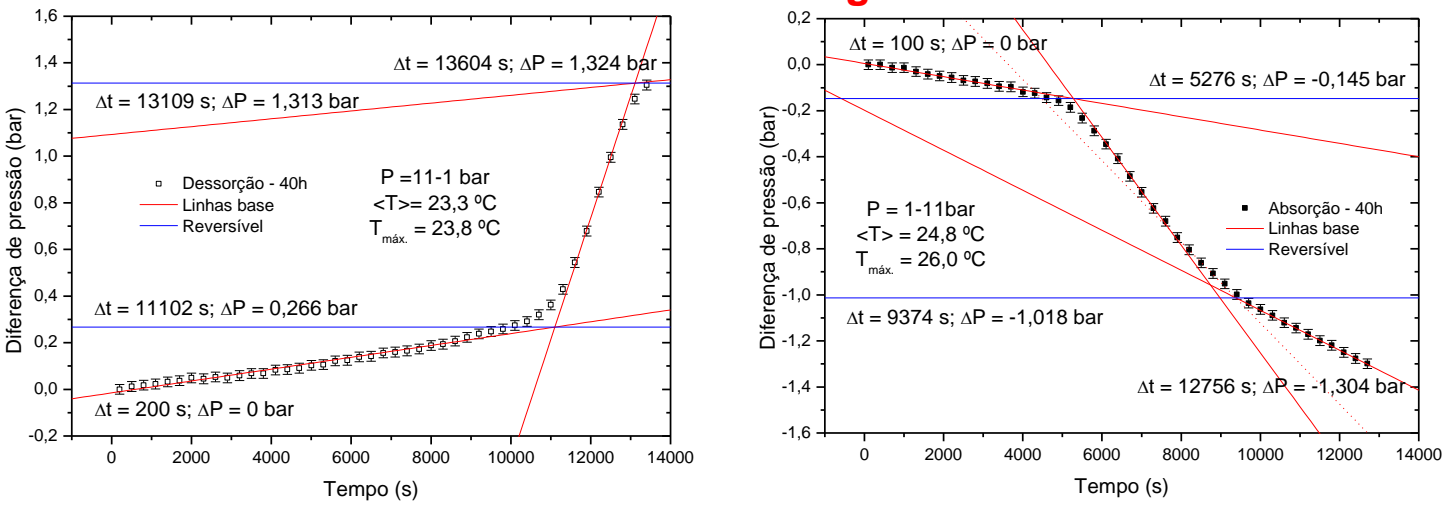

40 horas de moagem

FIGURA 44 - Diferença de pressão do equipamento em função do tempo para a dessorção e absorção de hidrogênio das amostras moídas por diferentes tempos e reagidas a $600^{\circ} \mathrm{C}$ da composição 56:44. 
TABELA 10 - Propriedades de dessorção de hidrogênio das amostras moídas por diferentes tempos e reagidas a 600C da composição 50:50.

\begin{tabular}{|c|c|c|c|c|c|c|c|c|}
\hline $\begin{array}{c}\text { Tempo de } \\
\text { moagem } \\
(\mathrm{h})\end{array}$ & Fase & $\begin{array}{c}<\phi_{\text {des }}> \pm \sigma<<\phi_{\text {des }}> \\
\left(\mathrm{cm}^{3} / \text { min.g }\right)\end{array}$ & $\mathrm{H}: \mathrm{M} \pm 0,013$ & $\begin{array}{c}\mathrm{H} \pm 0,025 \\
(\% \text { em massa) }\end{array}$ & $\begin{array}{c}<\mathrm{T}>/ \mathrm{T}_{\text {máx. }} \\
\quad\left({ }^{\circ} \mathrm{C}\right)\end{array}$ & $\begin{array}{c}\text { Faixa de } \\
\text { pressão } \\
\text { (bar) }\end{array}$ & $\begin{array}{c}\text { Platô de } \\
\text { pressão } \\
\text { (bar) }\end{array}$ & $\begin{array}{c}\text { TiFeH } \pm 4 \\
\text { (\% de formação) }\end{array}$ \\
\hline \multirow{4}{*}{5} & $\beta$ & $0,13 \pm 0,05$ & 0,057 & 0,110 & \multirow{4}{*}{$25,5 / 25,9$} & $11-6,6$ & \multirow{4}{*}{5,2} & \multirow{4}{*}{57} \\
\hline & $\alpha+\beta$ & $1,03 \pm 0,05$ & 0,266 & 0,514 & & $6,6-3,9$ & & \\
\hline & $\alpha$ & $0,07 \pm 0,05$ & 0,019 & 0,038 & & $3,9-1$ & & \\
\hline & Total & $0,352 \pm 0,013$ & 0,342 & 0,661 & & $11-1$ & & \\
\hline \multirow{4}{*}{10} & $\beta$ & $0,089 \pm 0,019$ & 0,061 & 0,118 & \multirow{4}{*}{$22,5 / 22,8$} & $11-4,4$ & \multirow{4}{*}{3,4} & \multirow{4}{*}{66} \\
\hline & $\alpha+\beta$ & $2,02 \pm 0,08$ & 0,314 & 0,607 & & $4,4-2,4$ & & \\
\hline & $\alpha$ & $0,10 \pm 0,08$ & 0,016 & 0,032 & & $2,4-1$ & & \\
\hline & Total & $0,391 \pm 0,013$ & 0,391 & 0,755 & & $11-1$ & & \\
\hline \multirow{4}{*}{25} & $\beta$ & $0,118 \pm 0,023$ & 0,065 & 0,125 & \multirow{4}{*}{$24,9 / 25,1$} & $11-5,3$ & \multirow{4}{*}{4,4} & \multirow{4}{*}{74} \\
\hline & $\alpha+\beta$ & $1,79 \pm 0,07$ & 0,340 & 0,657 & & $5,3-3,5$ & & \\
\hline & $\alpha$ & $0,12 \pm 0,05$ & 0,032 & 0,061 & & $3,5-1$ & & \\
\hline & Total & $0,440 \pm 0,013$ & 0,437 & 0,841 & & $11-1$ & & \\
\hline \multirow{4}{*}{40} & $\beta$ & $0,145 \pm 0,021$ & 0,088 & 0,170 & \multirow{4}{*}{$24,0 / 24,5$} & $11-5,1$ & \multirow{4}{*}{4,0} & \multirow{4}{*}{79} \\
\hline & $\alpha+\beta$ & $1,88 \pm 0,06$ & 0,382 & 0,738 & & $5,1-2,9$ & & \\
\hline & $\alpha$ & $0,07 \pm 0,06$ & 0,015 & 0,029 & & $2,9-1$ & & \\
\hline & Total & $0,480 \pm 0,013$ & 0,485 & 0,933 & & $11-1$ & & \\
\hline
\end{tabular}

Fase $\alpha$ (solução sólida TiFe e hidrogênio); Fase $\beta$ (hidreto $\beta$ TiFeH); TiFeH (\%de formação) é a porcentagem de hidreto formada em relação ao hidreto teórico $\beta$ TiFeH, sendo que o valor esperado para TiFeH (\%de formação) é de $\sim 100 \%$ após a completa extinção da fase $\alpha$ 
TABELA 11 - Propriedades de absorção de hidrogênio das amostras moídas por diferentes tempos e reagidas a 600C da composição 50:50.

\begin{tabular}{|c|c|c|c|c|c|c|c|c|}
\hline $\begin{array}{l}\text { Tempo de } \\
\text { moagem } \\
\text { (h) }\end{array}$ & Fase & $\begin{array}{c}<\phi_{\mathrm{abs}}> \pm \sigma<\phi_{\mathrm{abs}}> \\
\left(\mathrm{cm}^{3} / \mathrm{min} . \mathrm{g}\right)\end{array}$ & $\mathrm{H}: \mathrm{M} \pm 0,012$ & $\begin{array}{c}\mathrm{H} \pm 0,024 \\
(\% \text { em massa) }\end{array}$ & $\begin{array}{c}<\mathrm{T}>/ \mathrm{T}_{\text {máx. }} \\
\left({ }^{\circ} \mathrm{C}\right)\end{array}$ & $\begin{array}{c}\text { Faixa de } \\
\text { pressão } \\
\text { (bar) }\end{array}$ & $\begin{array}{c}\text { Platô de } \\
\text { pressão } \\
\text { (bar) }\end{array}$ & $\begin{array}{c}\mathrm{TiFeH} \pm 4 \\
\text { (\% de formação) }\end{array}$ \\
\hline \multirow{4}{*}{5} & $\alpha$ & $0,014 \pm 0,013$ & 0,014 & 0,027 & \multirow{4}{*}{$26,7 / 28,2$} & $1-9,2$ & \multirow{4}{*}{12,6} & \multirow{4}{*}{70} \\
\hline & $\alpha+\beta$ & $0,76 \pm 0,03$ & 0,335 & 0,646 & & $9,2-16,1$ & & \\
\hline & $\beta$ & $0,10 \pm 0,03$ & 0,047 & 0,092 & & $16,1-21$ & & \\
\hline & Total & $0,212 \pm 0,007$ & 0,396 & 0,763 & & $1-21$ & & \\
\hline \multirow{4}{*}{10} & $\alpha$ & $0,080 \pm 0,023$ & 0,044 & 0,086 & \multirow{4}{*}{$23,6 / 24,7$} & $1-6,5$ & \multirow{4}{*}{7,5} & \multirow{4}{*}{66} \\
\hline & $\alpha+\beta$ & $1,34 \pm 0,06$ & 0,286 & 0,552 & & $6,5-8,6$ & & \\
\hline & $\beta$ & $0,25 \pm 0,06$ & 0,054 & 0,105 & & $8,6-11$ & & \\
\hline & Total & $0,393 \pm 0,013$ & 0,384 & 0,741 & & $1-11$ & & \\
\hline \multirow{4}{*}{25} & $\alpha$ & $0,034 \pm 0,011$ & 0,037 & 0,071 & \multirow{4}{*}{$25,6 / 26,6$} & $1-12,2$ & \multirow{4}{*}{14,5} & \multirow{4}{*}{78} \\
\hline & $\alpha+\beta$ & $0,80 \pm 0,03$ & 0,355 & 0,685 & & $12,2-16,9$ & & \\
\hline & $\beta$ & $0,23 \pm 0,04$ & 0,076 & 0,148 & & $16,9-21$ & & \\
\hline & Total & $0,249 \pm 0,007$ & 0,468 & 0,901 & & $1-21$ & & \\
\hline \multirow{4}{*}{40} & $\alpha$ & $0,049 \pm 0,014$ & 0,044 & 0,085 & \multirow{4}{*}{$25,1 / 25,8$} & $1-10,6$ & \multirow{4}{*}{13,0} & \multirow{4}{*}{87} \\
\hline & $\alpha+\beta$ & $0,730 \pm 0,023$ & 0,393 & 0,757 & & $10,6-15,5$ & & \\
\hline & $\beta$ & $0,17 \pm 0,03$ & 0,081 & 0,157 & & $15,5-21$ & & \\
\hline & Total & $0,273 \pm 0,007$ & 0,517 & 0,995 & & $1-21$ & & \\
\hline
\end{tabular}

Fase $\alpha$ (solução sólida TiFe e hidrogênio); Fase $\beta$ (hidreto $\beta$ TiFeH); TiFeH (\%de formação) é a porcentagem de hidreto formada em relação ao hidreto teórico $\beta$ TiFeH, sendo que o valor esperado para TiFeH (\%de formação) é de $\sim 100 \%$ após a completa extinção da fase $\alpha$ 
TABELA 12 - Propriedades de dessorção de hidrogênio das amostras moídas por diferentes tempos e reagidas a 600C da composição 56:44.

\begin{tabular}{|c|c|c|c|c|c|c|c|c|}
\hline $\begin{array}{l}\text { Tempo de } \\
\text { moagem } \\
\text { (h) }\end{array}$ & Fase & $\begin{array}{c}<\phi_{\text {des }}> \pm \sigma<\phi_{\text {des }}> \\
\left(\mathrm{cm}^{3} / \text { min.g }\right)\end{array}$ & $\mathrm{H}: \mathrm{M} \pm 0,013$ & $\begin{array}{c}\mathrm{H} \pm 0,025 \\
(\% \text { em massa) }\end{array}$ & $\begin{array}{c}<\mathrm{T}>/ \mathrm{T}_{\text {máx. }} \\
\left({ }^{\circ} \mathrm{C}\right)\end{array}$ & $\begin{array}{c}\text { Faixa de } \\
\text { pressão } \\
\text { (bar) }\end{array}$ & $\begin{array}{c}\text { Platô de } \\
\text { pressão } \\
\text { (bar) }\end{array}$ & $\begin{array}{c}\mathrm{TiFeH} \pm 4 \\
\text { (\% de formação) }\end{array}$ \\
\hline \multirow{4}{*}{5} & $\beta$ & $0,082 \pm 0,020$ & 0,053 & 0,103 & \multirow{4}{*}{$22,7 / 22,9$} & $11-5,0$ & \multirow{4}{*}{3,9} & \multirow{4}{*}{60} \\
\hline & $\alpha+\beta$ & $1,94 \pm 0,08$ & 0,288 & 0,561 & & $5,0-2,8$ & & \\
\hline & $\alpha$ & $0,07 \pm 0,07$ & 0,013 & 0,025 & & $2,8-1$ & & \\
\hline & Total & $0,361 \pm 0,013$ & 0,354 & 0,689 & & $11-1$ & & \\
\hline \multirow{4}{*}{10} & $\beta$ & $0,107 \pm 0,018$ & 0,073 & 0,144 & \multirow{4}{*}{$27,6 / 28,1$} & $11-4,0$ & \multirow{4}{*}{3,2} & \multirow{4}{*}{75} \\
\hline & $\alpha+\beta$ & $2,55 \pm 0,09$ & 0,365 & 0,712 & & $4,0-2,3$ & & \\
\hline & $\alpha$ & $0,07 \pm 0,08$ & 0,010 & 0,021 & & $2,3-1$ & & \\
\hline & Total & $0,455 \pm 0,013$ & 0,449 & 0,874 & & $11-1$ & & \\
\hline \multirow{4}{*}{25} & $\beta$ & $0,160 \pm 0,016$ & 0,127 & 0,248 & \multirow{4}{*}{$27,9 / 28,4$} & $11-3,0$ & \multirow{4}{*}{2,2} & \multirow{4}{*}{86} \\
\hline & $\alpha+\beta$ & $2,71 \pm 0,08$ & 0,418 & 0,813 & & $3,0-1,5$ & & \\
\hline & $\alpha$ & $0,18 \pm 0,16$ & 0,015 & 0,029 & & $1,5-1$ & & \\
\hline & Total & $0,546 \pm 0,012$ & 0,559 & 1,085 & & $11-1$ & & \\
\hline \multirow{4}{*}{40} & $\beta$ & $0,134 \pm 0,015$ & 0,112 & 0,218 & \multirow{4}{*}{$23,3 / 23,8$} & $11-3,0$ & \multirow{4}{*}{2,2} & \multirow{4}{*}{89} \\
\hline & $\alpha+\beta$ & $2,86 \pm 0,08$ & 0,439 & 0,854 & & $3,0-1,3$ & & \\
\hline & $\alpha$ & $0,1 \pm 0,3$ & 0,005 & 0,009 & & $1,3-1$ & & \\
\hline & Total & $0,542 \pm 0,012$ & 0,555 & 1,078 & & $11-1$ & & \\
\hline
\end{tabular}

Fase $\alpha$ (solução sólida TiFe e hidrogênio); Fase $\beta$ (hidreto $\beta$ TiFeH); TiFeH (\%de formação) é a porcentagem de hidreto formada em relação ao hidreto teórico $\beta$ TiFeH, sendo que o valor esperado para TiFeH (\%de formação) é de $\sim 100 \%$ após a completa extinção da fase $\alpha$ 
TABELA 13 - Propriedades de absorção de hidrogênio das amostras moídas por diferentes tempos e reagidas a $6000^{\circ} \mathrm{C}$ da composição 56:44.

\begin{tabular}{|c|c|c|c|c|c|c|c|c|}
\hline $\begin{array}{l}\text { Tempo de } \\
\text { moagem } \\
\text { (h) }\end{array}$ & Fase & $\begin{array}{c}<\phi_{\mathrm{abs}}> \pm \sigma<\phi_{\mathrm{abs}}> \\
\left(\mathrm{cm}^{3} / \mathrm{min} \mathrm{g}\right)\end{array}$ & $\mathrm{H}: \mathrm{M} \pm 0,012$ & $\begin{array}{c}\mathrm{H} \pm 0,024 \\
(\% \text { em massa })\end{array}$ & $\begin{array}{c}<\mathrm{T}>/ \mathrm{T}_{\text {máx. }} . \\
\left({ }^{\circ} \mathrm{C}\right)\end{array}$ & $\begin{array}{c}\text { Faixa de } \\
\text { pressão } \\
\text { (bar) }\end{array}$ & $\begin{array}{l}\text { Platô de } \\
\text { pressão } \\
\text { (bar) }\end{array}$ & $\begin{array}{c}\mathrm{TiFeH} \pm 4 \\
\text { (\% de formação) }\end{array}$ \\
\hline \multirow{4}{*}{5} & $\alpha$ & $0,080 \pm 0,016$ & 0,006 & 0,011 & \multirow{4}{*}{$24,2 / 25,7$} & $1-7,8$ & \multirow{4}{*}{11,2} & \multirow{4}{*}{74} \\
\hline & $\alpha+\beta$ & $0,83 \pm 0,03$ & 0,365 & 0,712 & & $7,8-14,7$ & & \\
\hline & $\beta$ & $0,046 \pm 0,019$ & 0,030 & 0,060 & & $14,7-21$ & & \\
\hline & Total & $0,216 \pm 0,007$ & 0,402 & 0,782 & & $1-21$ & & \\
\hline \multirow{4}{*}{10} & $\alpha$ & $0,07 \pm 0,03$ & 0,025 & 0,048 & \multirow{4}{*}{$24,8 / 25,6$} & $1-4,7$ & \multirow{4}{*}{8,0} & \multirow{4}{*}{85} \\
\hline & $\alpha+\beta$ & $0,615 \pm 0,019$ & 0,399 & 0,777 & & $4,7-11,2$ & & \\
\hline & $\beta$ & $0,067 \pm 0,014$ & 0,058 & 0,114 & & $11,2-21$ & & \\
\hline & Total & $0,256 \pm 0,007$ & 0,482 & 0,937 & & $1-21$ & & \\
\hline \multirow{4}{*}{25} & $\alpha$ & $0,12 \pm 0,03$ & 0,047 & 0,093 & \multirow{4}{*}{$27,9 / 28,9$} & $1-5,0$ & \multirow{4}{*}{6,4} & \multirow{4}{*}{91} \\
\hline & $\alpha+\beta$ & $1,23 \pm 0,04$ & 0,408 & 0,793 & & $5,0-7,9$ & & \\
\hline & $\beta$ & $0,36 \pm 0,05$ & 0,091 & 0,178 & & $7,9-11$ & & \\
\hline & Total & $0,565 \pm 0,013$ & 0,546 & 1,060 & & $1-11$ & & \\
\hline \multirow{4}{*}{40} & $\alpha$ & $0,15 \pm 0,03$ & 0,059 & 0,116 & \multirow{4}{*}{$24,8 / 26,0$} & $1-5,0$ & \multirow{4}{*}{6,4} & \multirow{4}{*}{83} \\
\hline & $\alpha+\beta$ & $1,14 \pm 0,04$ & 0,357 & 0,696 & & $5,0-7,8$ & & \\
\hline & $\beta$ & $0,45 \pm 0,05$ & 0,117 & 0,229 & & $7,8-11$ & & \\
\hline & Total & $0,552 \pm 0,013$ & 0,534 & 1,037 & & $1-11$ & & \\
\hline
\end{tabular}


No que concerne a capacidade de armazenamento de hidrogênio das amostras, representadas pelas relações H:M e H (ver FIGURA 45 e TABELA 10 até a TABELA 13), observa-se que, de forma geral, todas as amostras absorveram e dessorveram quantidades significativas de hidrogênio, sendo que os piores resultados neste sentido (próximos aos $70 \%$ do valor esperado para o hidreto $\beta \mathrm{TiFeH}$ ) foram verificados nas amostras moídas por 5 e 10 horas da composição 50:50 e 5 horas da composição 56:44. Os melhores resultados foram observados nas amostras moídas por 25 e 40 da composição 50:50 e nas amostras moídas por 10, 25 e 40 horas da composição 56:44, com valores próximos aos $90 \%$. É importante destacar que estas análises não levam em consideração o número de sítios ativos para a nucleação das fases hidreto nas amostras (\% em massa da fase TiFe), tendo assim um aspecto mais geral. Ainda com relação à capacidade de armazenamento, fica evidente que as maiores porcentagens de hidrogênio são armazenadas nas fases hidreto propriamente ditas $(\alpha+\beta)$, com até 75 e $79 \%$ dos valores totais de hidrogênio absorvido e dessorvido pelas amostras. Há que se ressaltar ainda, que em nenhuma das condições investigadas foi atingida a capacidade máxima de armazenamento esperada para a fase $\beta \mathrm{TiFeH}$, mesmo quando se levou em consideração o número de sítios ativos para a nucleação destas fases, resultado provavelmente associado a presença de hidrogênio residual nas amostras após o ciclo de hidretação.

A possível presença deste hidrogênio residual foi então avaliada por absorção de radiação infravermelha (IV) e deslocamento dos picos de difração (lei de Vegard, DP), cujos resultados das estimativas são apresentados na TABELA 14. Tais estimativas indicam que de fato parte do hidrogênio que foi absorvido na ciclagem não pode ser revertido novamente em hidrogênio molecular, sendo o pior resultado neste sentido apresentado pela amostra moída por 10 horas da composição 50:50, com cerca de 16\% (ou 15\% pelo deslocamento do pico) de hidrogênio residual, algo que corrobora as observações já feitas com relação a capacidade de armazenamento reversível das amostras. Ainda sobre estas estimativas, é possível observar que a porcentagem de hidrogênio residual nas amostras tende a diminuir com 0 aumento do tamanho médio de cristalito do TiFe. 
Outro aspecto curioso, que pode ser observado na TABELA 14, diz respeito à desestabilização das soluções sólidas $\mathrm{TiFe}(\mathrm{Ti})$, algo que fica evidenciado pela maior discrepância entre as diferentes estimativas (IV e DP). De fato, observando cuidadosamente os difratogramas da FIGURA 39 e FIGURA 40, é possível verificar, especialmente nas amostras moídas por menores tempos, um maior deslocamento para a direita dos picos (110) da fase TiFe supersaturada de Ti, um indicativo claro de que as soluções sólidas podiam estar sofrendo uma maior desestabilização após o ciclo de hidretação. Tal fenômeno foi quase sempre seguido de um aumento no tamanho de médio de cristalito, bem como de uma diminuição das microdeformações, algo que pode ser mais bem observado nas curvas da FIGURA 41, e corrobora as observações feitas anteriormente com relação à primeira absorção de hidrogênio das amostras.

TABELA 14 - Estimativas de hidrogênio residual no composto TiFe após o ciclo de hidretação das amostras moídas por diferentes tempos e reagidas a $600^{\circ} \mathrm{C}$ das composições 50:50 e 56:44.

\begin{tabular}{|c|c|c|c|c|c|c|}
\hline \multirow{2}{*}{$\begin{array}{l}\text { Tempo de } \\
\text { moagem } \\
\text { (h) }\end{array}$} & \multicolumn{2}{|c|}{$\begin{array}{l}\text { Composição } \\
\text { nominal (Ti:Fe) } \\
\text { at. }(\%)\end{array}$} & \multirow[t]{2}{*}{$(\mathrm{H}: \mathrm{M})_{\mathbb{V}}$} & \multirow[t]{2}{*}{$\begin{array}{l}\mathrm{TiFeH}_{\mathrm{IV}} \\
\text { (\% de } \\
\text { formação) }\end{array}$} & \multirow[t]{2}{*}{$(\mathrm{H}: \mathrm{M})_{\mathrm{DP}}$} & \multirow[t]{2}{*}{$\begin{array}{c}\mathrm{TiFeH}_{\mathrm{DP}} \\
\text { (\% de } \\
\text { formação) }\end{array}$} \\
\hline & $\mathrm{Ti}$ & $\mathrm{Fe}$ & & & & \\
\hline 5 & \multirow{4}{*}{50} & \multirow{4}{*}{50} & 0,017 & 3 & 0,008 & 2 \\
\hline 10 & & & 0,080 & 16 & 0,075 & 15 \\
\hline 25 & & & 0,051 & 10 & 0,013 & 3 \\
\hline 40 & & & 0,033 & 7 & 0,034 & 7 \\
\hline 5 & \multirow{4}{*}{56} & \multirow{4}{*}{44} & 0,005 & 1 & $-0,109$ & - \\
\hline 10 & & & 0,007 & 1 & $-0,065$ & - \\
\hline 25 & & & 0,030 & 6 & 0,015 & 3 \\
\hline 40 & & & 0,034 & 7 & 0,018 & 4 \\
\hline
\end{tabular}

$(\mathrm{H}: \mathrm{M})_{\text {IV }}$ se refere a razão atômica hidrogênio-metal estimada a partir das análises por absorção de radiação infravermelha das referidas amostras. Nos cálculos dessas estimativas foram descontados os valores das \% em massa de hidrogênio referentes ao hidreto $\mathrm{TiH}_{2} ;(\mathrm{H}: \mathrm{M})_{\mathrm{DP}}$ se refere a razão atômica hidrogênio-metal estimada a partir do deslocamento (antes e após ciclo) do pico (110) da fase TiFe (ou da fase TiFe supersaturada de Ti) das amostras reagidas em relação ao pico (110) da solução sólida $\mathrm{TiFeH}_{0,06}$; TiFeH (\% de formação) é a porcentagem de hidrogênio residual em relação ao hidreto teórico $\beta \mathrm{TiFeH}$. 
Com relação aos platôs de absorção e dessorção de hidrogênio, apresentados nas curvas PCTs da FIGURA 45 (ver também TABELA 10 até TABELA 13), observa-se que aparentemente quanto maior a variação composicional da fase TiFe (maior teor de Ti em solução sólida no TiFe), assim como as porcentagens em massa de $\mathrm{TiH}_{2}$ livre nas amostras, menores são os platôs de absorção e dessorção de hidrogênio, possibilidade que já havia sido aventada anteriormente. Embora, como também já havia sido observado, as amostras moídas por menores tempos, especialmente as por 5 horas, tenham fugido a este fenômeno, resultado possivelmente ligado a menor quantidade destas soluções, seja pela menor formação durante as moagens, ou mesmo pela maior desestabilização após o ciclo de hidratação. Os melhores resultados em termos de capacidade máxima de armazenamento reversível a platôs de pressão relativamente baixos foram obtidos nas amostras moídas por 25 e 40 horas da composição 56:44. Estas amostras puderam absorver hidrogênio à temperatura ambiente sob os platôs de aproximadamente 6,4 bar $(\sim 0,6 \mathrm{MPa})$, atingindo sua capacidade máxima de armazenamento $\mathrm{H}: M \sim 0,546$ (ou 1,06\% em massa de $\mathrm{H}_{2}$ ) sob a pressão de até 11 bar $(1,1 \mathrm{MPa})$. As mesmas amostras puderam dessorver hidrogênio também à temperatura ambiente sob os platôs de aproximadamente 2,2bar (0,2MPa), revertendo até $\mathrm{H}: \mathrm{M} \sim 0,559$ (ou 1,085\% em massa de $\left.\mathrm{H}_{2}\right)$ sob a pressão de até 1 bar $(0,1 \mathrm{MPa})$, resultados compatíveis com os observados na literatura revisada (ver FIGURA 46).

Ainda com relação aos platôs das curvas PCTs, nota-se que em nenhuma das condições investigadas, mesmo naquelas onde se utilizaram maiores pressões (até 21bar), foi formada a fase $\gamma \mathrm{TiFeH}_{2}$, uma questão recorrente da literatura, já associada a um aumento da solubilidade de hidrogênio nas demais fases da hidretação. Também não foram verificadas grandes variações de temperatura durante as hidretações, sendo que a máxima variação observada não passou dos $1,4^{\circ} \mathrm{C}$ em relação à temperatura média do processo de hidretação. 

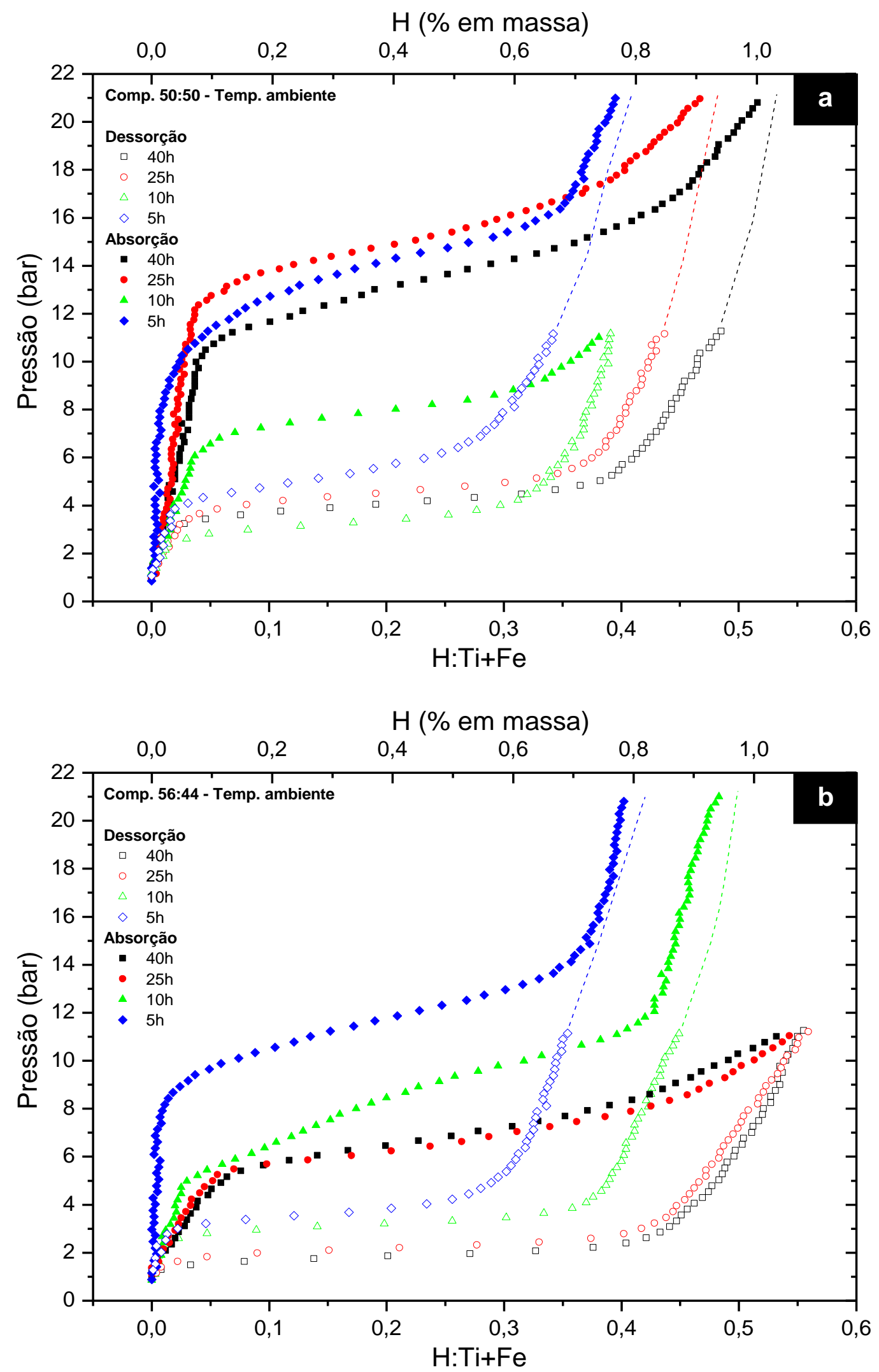

FIGURA 45 - Curvas PCTs à temperatura ambiente para as amostras moídas por diferentes tempos e reagidas a $600^{\circ} \mathrm{C}$ das composições: (a) 50:50; (b) $56: 44$. 

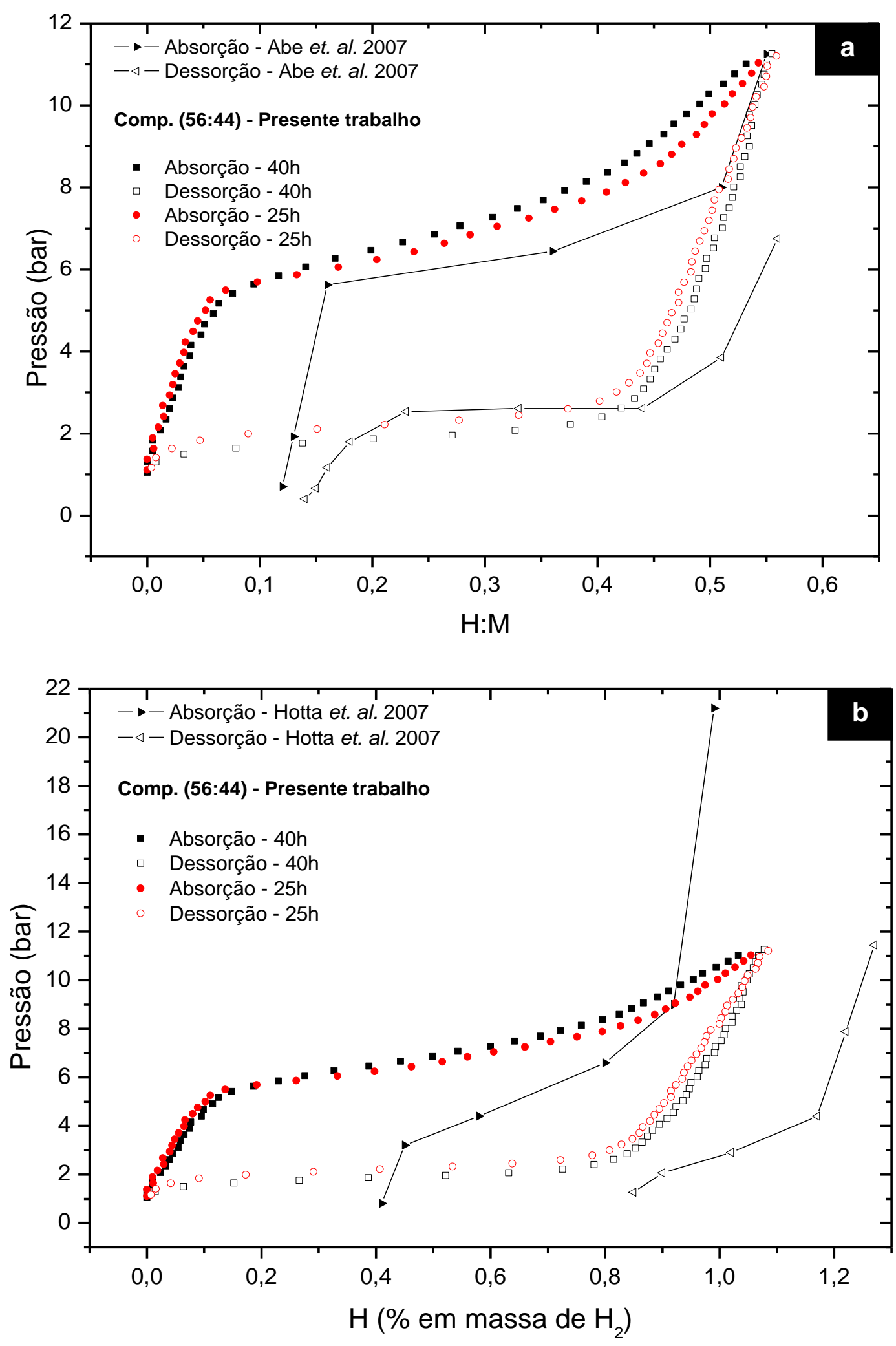

FIGURA 46 - Comparação das curvas PCTs dos melhores resultados obtidos no presente trabalho com os obtidos da literatura: (a) Abe et al. (2007); (b) Hotta et al. (2007). 
Já com relação às taxas de absorção e dessorção de hidrogênio das amostras, apresentadas nas curvas da FIGURA 47, verifica-se que, de forma geral, os fluxos $<\phi_{\text {abs }}>$ e $<\phi_{\text {des }}>$ são aparentemente maiores na dessorção do que na absorção de hidrogênio, assim como na formação das fases hidreto $(\beta+\alpha)$ em relação às demais fases da hidretação $(\beta$ e $\alpha)$. Já quando confrontadas entre os diferentes tempos de moagem, os fluxos das amostras moídas por 10 horas do lote 50:50, assim como o das amostras moídas por 25 e 40 horas do lote composicional 56:44, apresentaram uma sensível melhora em relação as demais amostras, com um aumento de até 118 e $178 \%$ em relação aos piores fluxos de absorção e dessorção (melhor cinética de absorção e dessorção).

O fenômeno observado, como já havia sido discutido anteriormente, parece estar relacionado à variação composicional da fase TiFe (maior teor de Ti em solução sólida no TiFe), assim como com as maiores porcentagens em massa de $\mathrm{TiH}_{2}$ livre nas amostras. Realmente, se observarmos os casos das amostras moídas por 25 e 40 horas da composição 50:50, que apresentavam características mais próximas as do composto estequiométrico, além de porcentagens não significativas de $\mathrm{TiH}_{2}$ livre, esta hipótese parece ser coerente. Contudo, no caso das amostras moídas por 5 horas da composição 50:50 e 5 e 10 horas da composição 56:44, que também apresentavam uma maior variação composicional, assim como porcentagem significativa de $\mathrm{TiH}_{2}$ livre, este fenômeno parece não ter se confirmado. Nestes casos, a questão da maior desestabilização das soluções $\mathrm{TiFe}(\mathrm{Ti})$, seguidas de um aumento do tamanho médio de cristalito, bem como de uma redução das microdeformações, parece ter sido determinante. É importante observar ainda que, especialmente no caso das amostras moídas por 5 horas, o menor número de sítios ativos para a nucleação da fase hidreto em relação às demais amostras também pode ter influenciado negativamente estes resultados. 

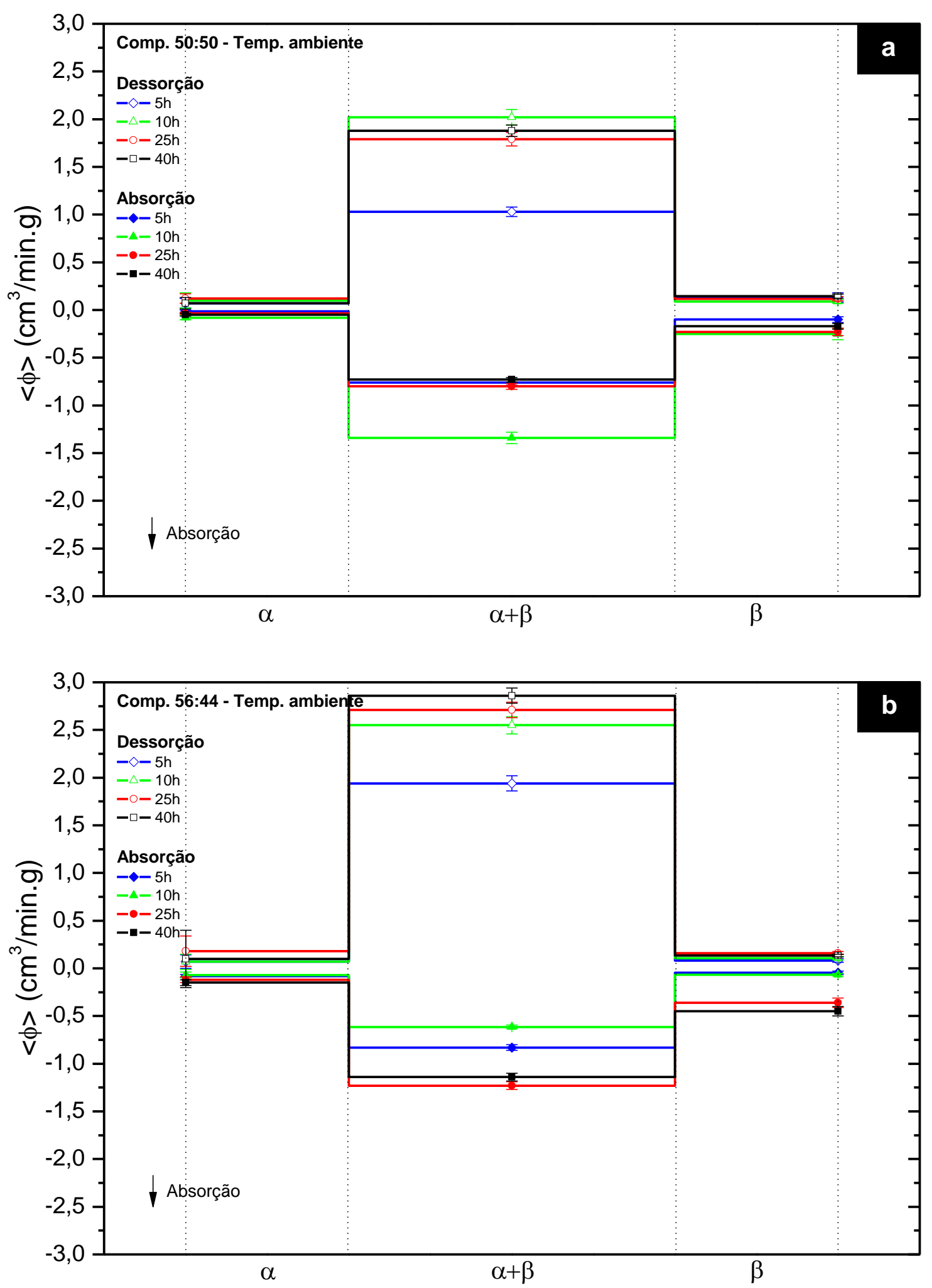

FIGURA 47 - Fluxos de dessorção e absorção de hidrogênio das amostras moídas por diferentes tempos e reagidas a $600^{\circ} \mathrm{C}$ das composições: (a) 50:50; (b) 56:44. 


\section{CONCLUSÕES}

Foi desenvolvida uma rota de processamento bem sucedida, a julgar pelos seguintes aspectos:

- Elevado rendimento de moagem;

- Obtenção majoritária da fase desejada;

- Obtenção de material ativo;

- Obtenção de material com boas propriedades de absorção e dessorção de hidrogênio.

A melhor rota de processamento investigada neste trabalho é constituída pelas seguintes etapas:

1) Moagem mecânica da mistura $\mathrm{TiH}_{2}$ e Fe;

Com a moagem da mistura $\mathrm{TiH}_{2}$ e Fe a aderência dos pós ao ferramental de moagem foi controlada com sucesso (rendimentos $290 \%$ ) em todas as condições de moagem investigadas $(5,10,25$ e 40h das composições 50:50 e 56:44). $\mathrm{O} \mathrm{TiH_{2 }}$ agiu como um controlador de processo intrínseco, diminuindo sobremaneira a aderência dos pós ao ferramental de moagem.

2) Tempo de moagem de 25 horas;

Os melhores resultados em termos de capacidade máxima de armazenamento reversível em platôs de pressão relativamente baixos foram obtidos nas amostras moídas por 25 e 40 horas do lote 56:44. Estas amostras puderam absorver hidrogênio à temperatura ambiente ( 298K) sob os platôs de aproximadamente $6,4 \mathrm{bar}(\sim 0,6 \mathrm{MPa})$, atingindo suas capacidades máximas de armazenamento H:M 0,546 (ou 1,06\% em massa de $\mathrm{H}_{2}$ ) sob a pressão de até $11 \mathrm{bar}(1,1 \mathrm{MPa})$. As mesmas amostras puderam dessorver hidrogênio também à temperatura ambiente sob os platôs de 
aproximadamente 2,2bar ( 0,2MPa), revertendo até $\mathrm{H}: \mathrm{M} \sim 0,559$ (ou 1,085\% em massa de $\left.\mathrm{H}_{2}\right)$ sob a pressão de até 1 bar $(0,1 \mathrm{MPa})$. As mesmas amostras apresentaram ainda um dos melhores resultados em termos de cinética de absorção e dessorção de hidrogênio com 1,23 (25h) e 2,86 cm $3 /$ g.min (40h). Todas estas melhorias observadas também foram associadas à variação composicional das fases TiFe e a maior porcentagem em massa de $\mathrm{TiH}_{2}$ livre nas amostras. Uma vez que os resultados destas duas condições foram semelhantes, escolheu-se o tempo de 25 horas por ser menor. Os menores tempos de moagem (5 e 10h) não proporcionaram resultados satisfatórios neste sentido.

3) Reação de síntese da mistura moída segundo a proporção 56:44 (Ti:Fe), sob alto vácuo, a $600^{\circ} \mathrm{C}(873 \mathrm{~K})$;

O composto TiFe nanoestruturado (tamanho médio de cristalito entre 12,5 e $21,4 \mathrm{~nm}$ ) foi sintetizado com sucesso após os tratamentos térmicos a $600^{\circ} \mathrm{C}$ (873K) das misturas moídas dos lotes composicionais (50:50 e 56:44). Após as reações de síntese foi constatado, no caso do lote 56:44, significativa variação composicional do TiFe em relação ao lote estequiométrico 50:50 (excesso de $\mathrm{Ti}$ em solução no TiFe), refletida na expansão da rede do composto (aumento dos parâmetros de rede de $\sim 0,4 \%$ em relação ao padrão do TiFe estequiométrico).

4) Injeção imediata de 21 bar (2,1MPa) de hidrogênio seguida de resfriamento;

A injeção imediata de hidrogênio mostrou-se crucial para a proteção da superfície do TiFe recém reagido, que foi capaz de absorver hidrogênio nas etapas finais do resfriamento, a partir de aproximadamente $90^{\circ} \mathrm{C}(\sim 363 \mathrm{~K})$, sem a necessidade, portanto, de posteriores ciclagens térmicas. Além do fato da primeira absorção de hidrogênio ter sido realizada in situ (no mesmo local onde as amostras foram reagidas), a variação composicional da fase $\mathrm{TiFe}$ e a maior porcentagem em massa de $\mathrm{TiH}_{2}$ livre nas amostras (casos dos compósitos $\mathrm{TiFe}^{-\mathrm{TiH}_{2}}$ ) contribuíram para a manutenção da atividade. 


\section{SUGESTÕES PARA TRABALHOS FUTUROS}

- Investigar o tempo ótimo de moagem (entre 10 e $25 \mathrm{~h}$ de moagem, mantendo-se as atuais condições de processo);

- Realizar experimentos (curvas PCTs) com um maior número de ciclagens;

- Caracterizar o TiFe não estequiométrico por difração de nêutrons para se avaliar o grau de ocupação do Ti (em excesso) e o grau de desordem estrutural;

- Avaliar a possibilidade de se aplicar a rota investigada (moagem mecânica do hidreto dos pós de partida seguida de reação de síntese) em outros sistemas de armazenamento de hidrogênio. 
[1] REILLY, J. J.; WISWALL, R. H. Formation and properties of iron titanium hydride. Inorg. Chem., v. 13, n. 1, p. 218-222, 1974.

[2] HOTTA, H.; ABE M.; KUJI, T.; USHIDA, H. Synthesis of Ti-Fe alloys by mechanical alloying. J. Alloys Compd., 2007, v. 439, n. 1-2, p. 221-226.

[3] ABE, M.; KUJI, T. Hydrogen absorption of TiFe alloy synthesized by ball milling and post-annealing. J. Alloys Compd., v. 446-447, p. 200-203, 2007.

[4] HARAKI, T.; OISHI, K.; UCHIDA, H.; MIYAMOTO, Y.; ABE, M.; KOKAJI, T.; UCHIDA, S. Properties of hydrogen absorption by nanostructured FeTi alloys. Int. J. Mater. Res., v. 9, p. 507-512, 2008.

[5] ZADOROZHNYY, V. Y.; KLYAMKIN, S. N.; KALOSHKIN, S. D.; ZADOROZHNYY, M. Y.; BERMESHEVA, O. V. Mechanochemical synthesis and hydrogen sorption properties of nanocrystalline TiFe. Inorg. Mater., v. 47, n. 10, p. 1081-1086, 2011.

[6] NOVAKOVA, A. A.; AGLADZE, O. V.; TARASOV, B. P. Structure tranformations during mechanical griding of $\mathrm{Fe}-\mathrm{TiH}_{2}$ mixture. Russ. J. Inorg. Chem., v. 45, n. 8, p. 1168-1172, 2000.

[7] NOVAKOVA, A. A.; AGLADZE, O. V.; SVESHNIKOV, S. V. TARASOV, B. P. Supersaturated solid solutions and metastable phases formation through different stages of mechanical alloying of FeTi. Nanostruct. Mater., v. 10, n. 3, p. 365-374, 1998.

[8] ZALUSKI, L.; TESSIER, P.; RYAN, D. H.; DONER, C. B.; ZALUSKA, A.; STRÖM-OLSEN, J. O.; TRUDEAU, M. L.; SCHULZ, R. Amorphous and nanocrystalline Fe-Ti prepared by ball milling. J. Mater. Res., v. 8, n. 12, p. 3059-3068, 1993.

[9] FALCÃO, R. B.; DAMMANN, E. D. C. C.; DA ROCHA, C. J.; LEAL NETO, R. M. An investigation on the mechanical alloying of TiFe compound by high-energy ball milling. Mater. Sci. Forum, v. 660-661, p. 329-334, 2010.

[10] FALCÃO, R. B. Obetenção do TiFe por moagem com alta energia. 2011. Dissertação (Mestrado)-Instituto de Pesquisas Energéticas e Nucleares, São Paulo.

[11] LEAL NETO, R. M.; FALCÃO, R. B.; DAMMANN, E. D. C. C.; DA ROCHA, C. J. An investigation on the high-energy ball milling of irontitanium powder mixtures without process control agents. In: WORLD POWDER METALLURGY CONGRESS AND EXHIBITION, Out. 10-14, 2010, Florença. Proceedings of the World PM2010, 2010.

[12] EMPRESA DE PESQUISA ENERGÉTICA (EPE). Balanço energético nacional 2015. Rio de Janeiro, RJ, 2015. 
[13] CONTE, M.; IACOBAZZI, A.; RONCHETTI, M.; VELLONE, R. Hydrogen economy for a sustainable development: state-of-the-art and technological perspectives. J. Power Sources, v. 100, p. 171-187, 2001.

[14] ZÜTTEL, A.; REMHOF, A.; BORGSCHULTE, A.; FRIEDRICHS, O. Hydrogen: the future energy carrier. Philos. Trans. R. Soc. A, v. 368, n. 1923, p. 3329-3342, 2010.

[15] SANTANA, E.; DA CUNHA, K. B.; FERREIRA, A. L.; ZAMBONI, A. Padrões de qualidade do ar: experiência comparada Brasil, EUA e União Europeia. Instituto de Energia e Meio Ambiente (IEMA), São Paulo, SP, 2012.

[16] SCHLAPBACH, L.; ZÜTTEL, A. Hydrogen-storage materials for mobile applications, Nature, v. 414, p.353-358, 2001.

[17] ZÜTTEL, A. Materials for hydrogen storage. Materials Today, v. 6, n. 9, p. 24-33, 2003.

[18] ZÜTTEL, A. Hydrogen storage methods. Naturwissenschaften, v. 91, n. 4, p. 157-172, 2004.

[19] DORNHEIM, M.; EIGEN, N.; BARKHORDARIAN, G.; KLASSEN, T.; BORMANN, $E R$. Tailoring hydrogen storage materials towards application. Adv. Eng. Mater., v. 8, n. 5, p. 377-385, 2006.

[20] HANLON, J. M.; REARDON, H.; TAPIA-RUIZ, N.; GREGORY, D. H. The challenge of storage in the hydrogen energy cycle: nanostructured hydrides as a potential solution. Aust. J. Chem., v. 65, n. 6, p. 656-671, 2012.

[21] REILLY, J. J.; WISWALL, R. H. J.; HOFFMAN, K. C. Metal hydrides as a source of hydrogen fuel. In: $160^{\text {Th }}$ NATIONAL MEETING OF THE AMERICAN CHEMICAL SOCIETY, Set. 13-18, 1970, Chicago. Proceedings of the $\mathbf{1 6 0}^{\text {Th }}$ ACS National Meeting, 1970.

[22] LOVINS, A. B. Twenty hydrogen myths. Rocky Mountain Institute (RMI), Snowmass,CO, 2003.

[23] CENTRO DE GESTÃO E ESTUdOS ESTRATÉGICOS (CGEE). Hidrogênio energético no Brasil: subsídios para políticas de competitividade, 2010-2025. Brasília, DF, 2010.

[24] CONTE, M.; PROSINI, P. P.; PASSERINI, S. Overview of energy/hydrogen storage: state-of-the-art of the technologies and prospects for nanomaterials. Mater. Sci. Eng. B, v. 108, n. 1-2, p. 2-8, 2004.

[25] BÉRUBÉ, V.; RADTKE, G.; DRESSELHAUS, M.; CHEN, G. Size effects on the hydrogen storage properties of nanostructured metal hydrides: a review. Int. J. Energy Res., v. 31, n. 6-7, p. 637-663, 2007.

[26] G. STAN, G.; COLE, M. W. Hydrogen adsorption in nanotubes. J. Low Temp. Phys., v. 110, n 1-2, p. 539-544, 1998.

[27] SANDROCK, G. D.; GOODELL, P. D. Surface poisoning of LaNi ${ }_{5}, \mathrm{FeTi}$ and $(\mathrm{Fe}, \mathrm{Mn}) \mathrm{Ti}$ by $\mathrm{O}_{2}, \mathrm{CO}$ and $\mathrm{H}_{2} \mathrm{O}$. J. Less Common Met., v. 73, p. 161$168,1980$. 
[28] RUDMAN, P. S.; SANDROCK, G. D. Metallurgy of rechargeable hydrides. Annu. Rev. Mater. Sci., v. 12, n. 1, p. 271-294, 1982.

[29] GÜTHER, V.; OTTO, A. Recent developments in hydrogen storage applications based on metal hydrides. J. Alloys Compd., v. 293-295, p. 889-892, 1999.

[30] UCHIDA, H.; HARAKI, T.; OISHI, K.; MIYAMOTO, Y.; ABE, M.; KOKAJI T.; UCHIDA, S. A wind \& solar hybrid energy storage system using nanostructured hydrogen storage alloy", In: INTERNATIONAL HYDROGEN ENERGY CONGRESS AND EXHIBITION, Jul. 13-15, 2005, Istanbul. Proceedings of the IHEC2005, 2005.

[31] BUCHNER, H. Perspectives for metal hydride technology. Prog. Energy Combust. Sci., v. 6, n. 4, p. 331-346, 1980.

[32] CHOI, M. J.; HONG, H. S.; LEE, K. S. Electrochemical characteristics of the composite metal hydride of $\mathrm{TiFe}$ and $\mathrm{TiMn}_{2}$ synthesized by mechanical alloying. J. Alloys Compd., v. 358, n. 1-2, p. 306-311, 2003.

[33] JANKOWSKA, E.; MAKOWIECKA, M.; JURCZYK, M. Nickel-metal hydride battery using nanocrystalline TiFe-type hydrogen storage alloys. J. Alloys Compd., v. 404-406, p. 691-693, 2005.

[34] LÓPEZ-BÁEZ, I.; ESPINOZA-BELTRÁN, F. J.; BARREIRORODRÍGUEZ, G. Desarrollo de un nanomaterial base TiFe, como electrodo para baterías recargables tipo $\mathrm{NiMH}$, obtenido por aleado mecánico de alta energía. Rev. Mex. Física, v. 52, n. 3, p. 278-284, 2006.

[35] ZADOROZHNYY, M. Y.; KALOSHKIN, S. D.; KLYAMKIN, S. N.; BERMESHEVA, O. V.; ZADOROZHNYY, V. Y. Mechanochemical synthesis of a TiFe nanocrystalline intermetallic compound and its mechanical alloying with third component. Met. Sci. Heat Treat., v. 54, n. 9-10, p. 461-465, 2013.

[36] ABRASHEV, B.; SPASSOV, T.; BLIZNAKOV, S.; POPOV, A. Microstructure and electrochemical hydriding/dehydriding properties of ball-milled TiFe-based alloys. Int. J. Hydrogen Energy, v. 35, n. 12, p. 6332-6337, 2010.

[37] AKIBA, E.; IBA, H. Hydrogen absorption by laves phase related BCC solid solution. Intermetallics, v. 6, n. 6, p. 461-470, 1998.

[38] JUNG, C. B.; LEE, K. S. Electrode characteristics of metal hydride electrodes prepared by mechanical alloying. J. Alloys Compd., v. 253254, p. 605-608, 1997.

[39] TOEPLER, J.; BERNAUER, O.; BUCHNER, H. The use of hydrides in motor vehicles. J. Less Common Met., v. 74, n. 2, p. 385-399, 1980.

[40] TOEPLER, J.; BERNAUER, O.; BUCHNER, H.; SÄUFFERER, H. Development of hydrides for motor vehicles. J. Less Common Met., v. 89, n. 2, p. 519-526, 1983.

[41] CENTRO DE GESTÃO E ESTUdOS ESTRATÉGICOS (CGEE). Programa brasileiro de células a combustível. Brasília, DF, 2002. 
[42] SANDROCK, G.; THOMAS, G. The IEA/DOE/SNL on-line hydride databases. Appl. Phys. A., v. 72, n. 2, p. 153-155, 2001.

[43] MURRAY, J. L. Binary Alloy Phase Diagrams. 2.ed. Org. Metals Park, OH: American Society for Metals (ASM), 1990.

[44] ZALUSKI, L.; ZALUSKA, A.; STRÖM-OLSEN, J. O. Nanocrystalline metal hydrides. J. Alloys Compd., v. 253-254, p. 70-79, 1997.

[45] SANDROCK, G. A panoramic overview of hydrogen storage alloys from a gas reaction point of view. J. Alloys Compd., v. 293-295, p. 877-888, 1999.

[46] BOUOUDINA, M.; GRANT, D.; WALKER, G. Review on hydrogen absorbing materials-structure, microstructure, and thermodynamic properties. Int. J. Hydrogen Energy, v. 31, n. 2, p. 177-182, 2006.

[47] VARIN, R. A.; CZUJKO, T. Overview of processing of nanocrystalline hydrogen storage intermetallics by mechanical alloying/milling. Mater. Manuf. Process., v. 17, n. 2, p. 129-156, 2002.

[48] (SAM) FROES, F. H.; SURYANARAYANA, C.; RUSSELL, K.; LI, C.-G. Synthesis of intermetallics by mechanical alloying. Mater. Sci. Eng. A, v. 192-193, p. 612-623, 1995.

[49] BENJAMIN, J. S. Dispersion strengthened superalloys by mechanical alloying. Metall. Trans., v. 1, n. 10, p. 2943-2951, 1970.

[50] HUANG, B. L.; LAVERNIA, E. Materials synthesis by mechanical alloying. J. Mater. Synth. Process., v. 3, n. 1, p. 1-9, 1995.

[51] $\mathrm{KOCH}, \mathrm{C}$. C.; WHITTENBERGER, J. D. Mechanical milling/alloying of intermetallics. Intermetallics, v. 4, n. 5, p. 339-355, 1996.

[52] SURYANARAYANA, C. Mechanical alloying and milling. Prog. Mater. Sci., v. 46, n. 1-2, p. 1-184, 2001.

[53] BENJAMIN, J. S.; VOLIN, T. E. The mechanism of mechanical alloying. Metall. Trans., v. 5, n. 8, p. 1929-1934, 1974.

[54] LÜ, L.; LAI, M. O. Mechanical Alloying. 1.ed. Boston, MA: Kluwer Academic Publishers, 1998.

[55] AIKIN, B. J. M.; COURTNEY, T. H. The kinetics of composite particle formation during mechanical alloying. Metall. Trans. A, v. 24, n. 3, p. 647-657, 1993.

[56] BURGIO, N.; IASONNA, A.; MAGINI, M.; PADELLA, F. Mechanical alloying of the Fe-Zr system in different milling conditions. J. Phys. Colloq., v. 51, n. 4, p. 265-271, 1990.

[57] MURTY, B. S.; MOHAN RAO, M.; RANGANATHAN, S. Milling maps and amorphization during mechanical alloying. Acta Metall. Mater., v. 43, n. 6, p. 2443-2450, 1995. 
[58] ZADOROZHNYY, V.; KLYAMKIN, S.; ZADOROZHNYY, M.; BERMESHEVA, O.; KALOSHKIN, S. Hydrogen storage nanocrystalline TiFe intermetallic compound: synthesis by mechanical alloying and compacting. Int. J. Hydrogen Energy, v. 37, n. 22, p. 17131-17136, 2012.

[59] BONIFACIO-MARTÍNEZ, J.; UREÑA-NÚÑEZ, F.; ITURBE-GARCÍA, J. L. Characteristics of the $\mathrm{Ti}_{1.27} \mathrm{Fe}+11 \mathrm{wt} . \% \mathrm{Ni}$ composite obtained by arc melting and ball milling. J. Chem., v. 2013, p. 1-5, 2013.

[60] FALCÃO, R. B.; DAMMANN, E. D. C. C.; DA ROCHA, C. J.; ICHIKAWA, R. U.; DURAZZO, M.; MARTINEZ, L. G.; LEAL NETO, R. M. Synthesis of TiFe compound from ball milled $\mathrm{TiH}_{2}$ and Fe powders mixtures. Mater. Sci. Forum, v. 802, p. 61-65, 2014.

[61] EMAMI, H.; EDALATI, K.; MATSUDA, J.; AKIBA, E.; HORITA, Z. Hydrogen storage performance of TiFe after processing by ball milling. Acta Mater., v. 88, p. 190-195, 2015.

[62] SANDROCK, G. D.; GOODELL, P. D. Cyclic life of metal hydrides with impure hydrogen: overview and engineering considerations. J. Less Common Met., v. 104, n. 1, p. 159-173, 1984.

[63] SCHOBER, T. On the activation of FeTi for hydrogen storage. J. Less Common Met., v. 89, n. 1, p. 63-70, 1983.

[64] DAVIDS, M. W.; LOTOTSKYY, M. Influence of oxygen introduced in TiFe-based hydride forming alloy on its morphology, structural and hydrogen sorption properties. Int. J. Hydrogen Energy, v. 37, n. 23, p. 18155-18162, 2012.

[65] RAY, R.; GIESSEN, B. C.; GRANT, N. J. The constitution of metastable titanium rich Ti-Fe alloys: an order-disorder transition. Metall. Trans., v. 3, n. 3, p. 627-629, 1972.

[66] SCHLAPBACH, L.; RIESTERER, T. The activation of FeTi for hydrogen absorption. Appl. Phys. A, v. 32, n. 4, p. 169-182, 1983.

[67] AOYAGI, H.; AOKI, K.; MASUMOTO, T. Effect of ball milling on hydrogen absorption properties of $\mathrm{FeTi}, \mathrm{Mg}_{2} \mathrm{Ni}$ and $\mathrm{LaNi}_{5}$. J. Alloys Compd., v. 231, n. 1-2, p. 804-809, 1995.

[68] DOLGIN, B. P.; VANEK, M. A.; MCGORY, T.; HAM, D. J. Mechanical alloying of $\mathrm{Ni}, \mathrm{CO}$, and $\mathrm{Fe}$ with $\mathrm{Ti}$ : formation of an amorphous phase. $\boldsymbol{J}$. Non. Cryst. Solids, v. 87, n. 3, p. 281-289, 1986.

[69] ABRASHEV, B.; BLIZNAKOV, S.; SPASSOV, T.; POPOV, A. Electrochemical hydriding of nanocrystalline TiFe alloys. J. Appl. Electrochem., v. 37, n. 7, p. 871-875, 2007.

[70] ARIAS, A. Chemical reactions of metal powders with organic and inorganic liquids during ball milling. National Technique Information Service (NTIS), Springfield, VA, 1975.

[71] ZHANG, Y. F.; LU, L.; YAP, S. M. Prediction of the amount of PCA for mechanical milling. J. Mater. Process. Technol., v. 89-90, p. 260-265, 1999. 
[72] CHU, B.-L.; LEE, S.-M.; PERNG, T.-P. Preparation and hydrogen absorption property of amorphous Ti50Fe50. Int. J. Hydrogen Energy, v. 16, n. 6, p. 413-416, 1991.

[73] MIZUNO, T.; MOROZUMI, T. Titanium concentration in $\mathrm{FeTi}_{\mathrm{x}}(1 \leq \mathrm{x} \leq 2)$ alloys and its effect on hydrogen storage properties. J. Less Common Met., v. 84, p. 237-244, 1982.

[74] KHATAMIAN, D.; WEATHERLY, G. C.; MANCHESTER, F. D.; ALCOCK, C. B. Some observations on activation of FeTi for hydrogen absorption. J. Less Common Met., v. 89, n. 1, p. 71-76, 1983.

[75] LEE, S.-M.; PERNG, T.-P. Microstructural correlations with the hydrogenation kinetics of $\mathrm{FeTi}_{1+x}$ alloys. J. Alloys Compd., v. 177, n. 1, p. 107-118, 1991.

[76] MARTINEZ, L. G. Estudo da estrutura cristalina do composto supercondutor $\mathbf{H g}_{1-x} \mathrm{Re}_{x} \mathrm{Ba}_{2} \mathrm{Ca}_{2} \mathrm{Cu}_{3} \mathrm{O}_{8+\delta}-\mathrm{Hg}, \mathbf{R e - 1 2 2 3}$. 2005. Tese (Doutorado)-Instituto de Pesquisas Energéticas e Nucleares, São Paulo.

[77] YOUNG, R. A. The Rietveld Method. IUCr Monographs on Crystallography-5, International Union of Crystallography (IUCr), Oxford Science Publications, 1995.

[78] BALZAR D. Voigt-function model in diffraction line-broadening analysis. In: SNYDER, R. L.; BUNGE, H. J.; FIALA, J. Defect and Microstructure Analysis by Diffraction. IUCr Monographs on Crystallography-10, International Union of Crystallography (IUCr), Oxford Science Publications, 1999.

[79] GERARD, N.; BELKBIR, L.; JOLY, E. High-accuracy volumetric device for hydrogen sorption kinetic studies. J. Phys. E., v. 12, n. 6, p. 476-477, 1979.

[80] GOODELL, P.; SANDROCK, G.; HUSTON, E. Kinetic and dynamic aspects of rechargeable metal hydrides. J. Less Common Met., v. 73, p. 135-142, 1980.

[81] BHOSLE, V.; BABURAJ, E. G.; MIRANOVA, M.; SALAMA, K. Dehydrogenation of $\mathrm{TiH}_{2}$. Mater. Sci. Eng. A, v. 356, n. 1-2, p. 190-199, 2003.

[82] RAGHAVAN V. The Fe-O-Ti (Iron-Oxygen-Titanium) system, phase diagrams ternary iron alloys. Indian Inst. Met., v. 5, p. 300-325, 1989.

[83] CHIANG, C.-H.; CHIN, Z.-H.; PERNG, T.-P. Hydrogenation of TiFe by high-energy ball milling. J. Alloys Compd., v. 307, n. 1-2, p. 259-265, 2000.

[84] TAL-GUTELMACHER, E.; ELIEZER, D. Hydrogen-assisted degradation of titanium based alloys. Mater. Trans., v. 45, n. 5, p. 1594-1600, 2004.

[85] HAO, L.; LU, Y.; SATO, H.; ASANUMA, H.; GUO, J. Analysis on energy transfer during mechanical coating and ball milling-supported by electric power measurement in planetary ball mill. Int. J. Miner. Process., v. 121, p. 51-58, 2013.

[86] MUELLER, W. M.; BLACKLEDGE, J. P.; LIBOWITZ, G. G. Metal Hydride. Nova York, NY: Academic Press, 1968. 


\section{APÊNDICE A - Modelo simplificado de transferência de energia para moinhos do tipo planetário}

Para facilitar a reprodutibilidade dos resultados obtidos neste trabalho, e em outros que envolvam a moagem de alta energia em moinhos do tipo planetário, podemos utilizar um modelo simplificado, proposto por Burgio et al. (1990), e modificado por Murty et al. (1995). Neste modelo, uma bola de massa $m_{b}(\mathrm{Kg})$, é inicialmente arremessada com velocidade $v_{b}(\mathrm{~m} / \mathrm{s})$, contra a parede de um recipiente de moagem, adquirindo assim uma energia cinética $E_{b}(\mathrm{~J})$, dada por:

$$
E_{b}=\frac{m_{b} \cdot v_{b}^{2}}{2}
$$

Após sucessivas colisões, a bola perde velocidade até atingir uma velocidade $v_{s}(\mathrm{~m} / \mathrm{s})$, ficando assim com uma energia cinética residual $E_{s}(\mathrm{~J})$ dada por:

$$
E_{S}=\frac{m_{b} \cdot v_{s}^{2}}{2}
$$

A energia final $\Delta E$ liberada pela bola após as sucessivas colisões será:

$$
\Delta E=E_{b}-E_{s}
$$

As velocidades $v_{b}$ e $v_{s}$ dependem diretamente da distância entre os eixos de rotação do prato e do recipiente de moagem $R_{d}(\mathrm{~m})$, do raio do recipiente de moagem $R_{b}(\mathrm{~m})$, do raio da bola de moagem $r_{b}(\mathrm{~m})$, bem como das velocidades angulares de rotação do prato $\omega_{p}(\mathrm{rad} / \mathrm{s})$ e do recipiente de moagem $\omega_{b}(\mathrm{rad} / \mathrm{s})$ (ver FIGURA 48), podendo assim ser reescritas das seguintes formas:

$$
v_{b}^{2}=\left(R_{d} \cdot \omega_{p}\right)^{2}+\omega_{b}^{2} \cdot\left(R_{b}-r_{b}\right)^{2} \cdot\left(1+\frac{2 \cdot \omega_{b}}{\omega_{p}}\right)
$$




$$
v_{s}^{2}=\left(R_{d} \cdot \omega_{p}\right)^{2}+\omega_{b}^{2} \cdot\left(R_{b}-r_{b}\right)^{2}+2 \cdot \omega_{b} \cdot \omega_{p} \cdot R_{d}\left(R_{b}-r_{b}\right)
$$
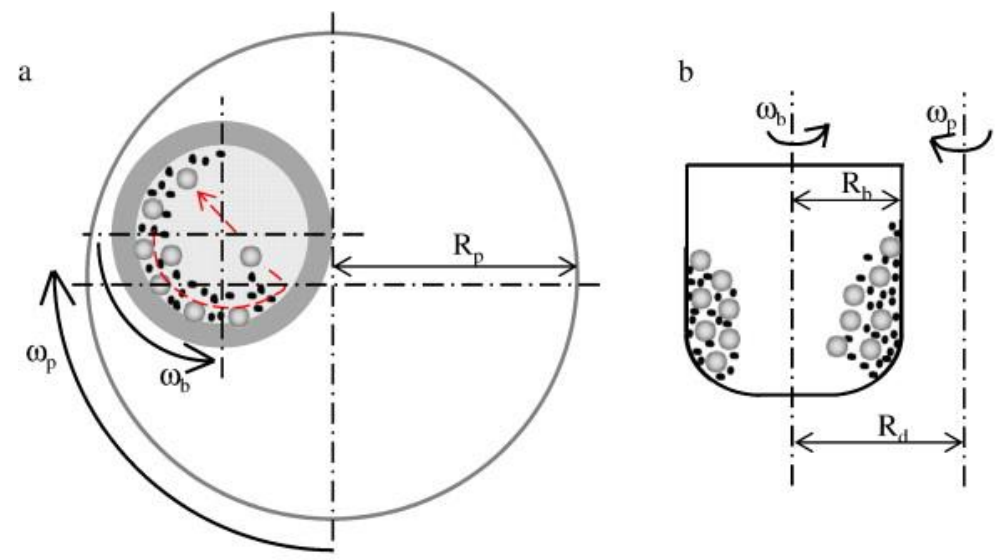

FIGURA 48 - Diagrama esquemático de um moinho do tipo planetário [85].

A frequência de impacto da bola no recipiente de moagem $f_{b}$, assim como as velocidades $v_{b}$ e $v_{s}$, também depende diretamente das variáveis $\omega_{p}$ e $\omega_{b}$, sendo dada por:

$$
f_{b}=\frac{\omega_{p}-\omega_{b}}{2 \pi}
$$

Altas frequência de impacto, assim como altas velocidades $v_{b}$ e $v_{s}$, podem resultar em mudanças indesejadas na microestrutura do pó durante o processo de moagem, resultado de um maior desgaste do ferramental de moagem e de um aumento da temperatura, o que torna o seu controle de fundamental importância para a obtenção de um material com as propriedades desejadas [54].

Outro ponto relevante na moagem de alta energia é o fator de preenchimento do recipiente $\varphi_{b}$, que pode ser relacionado com a energia $\Delta E$ da seguinte forma:

$$
\Delta E^{\prime}=\varphi_{b} . \Delta E
$$

Sendo $\varphi_{b}$ dado por:

$$
\varphi_{b}=1-\eta_{v}^{\delta}
$$


Com:

$$
\begin{aligned}
& \eta_{v}=\frac{n_{b}}{n_{b, v}} \\
& \left(\frac{n_{b, s}}{n_{b, v}}\right)^{\delta}=0,05
\end{aligned}
$$

Onde $\eta_{v}$ é a fração de empacotamento do recipiente de moagem em um arranjo de esferas cúbico simples, $n_{b}$ é o número de bolas adicionadas ao sistema, $n_{b, v}$ é número de esferas que o recipiente pode acomodar em um arranjo cúbico simples e $n_{b, s}$ é o número de esferas necessário para cobrir, também em um arranjo cúbico simples, um terço da superfície interna do recipiente de moagem. As condições de contorno para 0 fator de preenchimento do recipiente são dadas por:

1 - No caso em que o recipiente de moagem está completamente cheio: $n_{b}=n_{b, v} \Rightarrow \eta_{v}=1$, logo: $\varphi_{b}=0$ e $\Delta E^{\prime}=0$, isto é, não existe transferência de energia cinética das bolas para o pó.

2 - No caso em que só existe um bola no recipiente de moagem $n_{b, v} \gg \eta_{v} \Rightarrow \eta_{v}=0$ logo: $\varphi_{b}=1$, isto é, a transferência de energia cinética da bola para o pó é máxima.

Finalmente a energia total transferida $E_{t}(\mathrm{Wh} / \mathrm{g})$, após um tempo $t(\mathrm{~h})$ de moagem, das bolas para um pó com massa $m_{p}(\mathrm{~kg})$ será:

$$
E_{t}=\frac{\left(v_{b}^{2}-v_{s}^{2}\right)}{2} \cdot \varepsilon \cdot \varphi_{b} \cdot f_{b} \cdot t
$$

Onde a razão bola:pó $\varepsilon$ é dada por:

$$
\varepsilon=\frac{m_{b} \cdot n_{b}}{m_{p}}
$$




\section{APÊNDICE B - Metodologia empregada na análise dos dados fornecidos pelo equipamento Sievert}

Para calcular o volume de hidrogênio absorvido ou dessorvido pelas amostras $\Delta V_{a b s / d e s}$, foi obtida a curva de pressão correspondente à variação de hidrogênio no equipamento em função do tempo $P_{a b s / d e s}(t)$. Para tal, foram subtraídos os dados de pressão, obtidos em um experimento com amostra, dos dados de um experimento em branco, obtidos a partir de um procedimento experimental idêntico, porém sem amostra (ver FIGURA 49 e FIGURA 50).

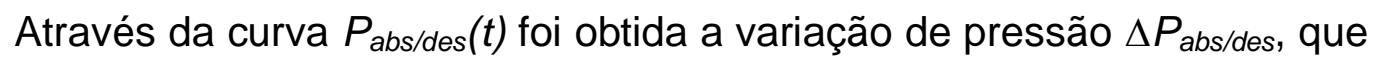
é diretamente proporcional ao volume de hidrogênio absorvido ou dessorvido pelas amostras $\Delta V_{\text {abs/des }}$ no intervalo $a \leq t \leq b$, assim como a taxa de pressurização ou de despressurização do volume de trabalho do equipamento $\Phi_{\text {entsaid }}$ é proporcional ao fluxo de entrada ou de saída de hidrogênio pelo fluxômetro $\phi_{\text {entsaid. }}$ Com base nestas relações, obteve-se a EQUAÇÃO 13, onde o volume absorvido ou dessorvido de hidrogênio é dado nas CNTP (Condições Normais de Temperatura e Pressão), uma vez que o fluxômetro foi calibrado inicialmente nessas condições.

$$
\Delta V_{a b s / d e s}\left[\mathrm{~cm}^{3}\right]=\left(\frac{\Delta P_{a b s / d e s}[\text { bar }]}{\Phi_{\text {ent } / \text { said }}\left[\frac{\text { bar }}{s}\right]}\right) \cdot \phi_{\text {ent } / \text { said }}\left[\frac{\mathrm{cm}^{3}}{\mathrm{~s}}\right]
$$

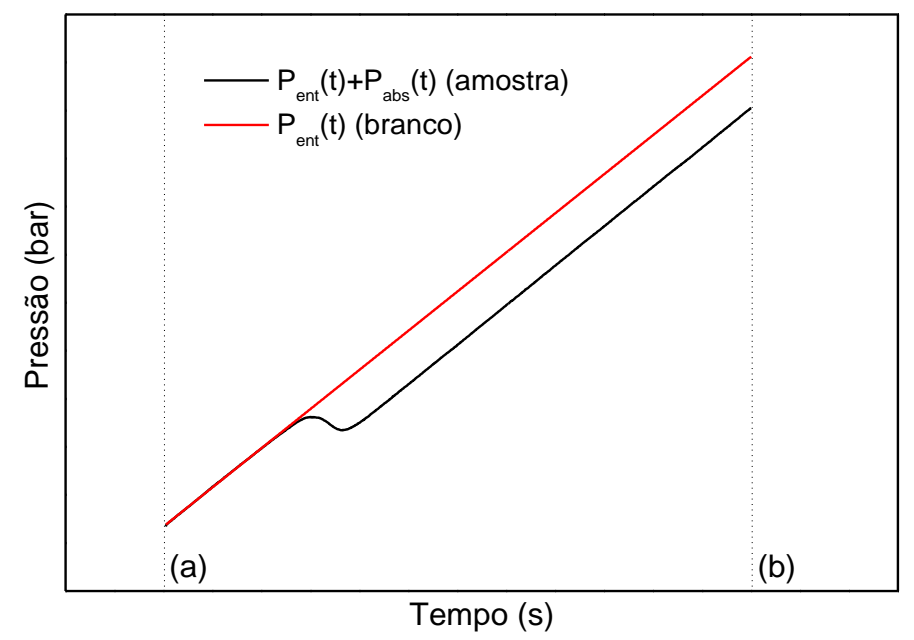

FIGURA 49 - Curvas típicas de pressão em função do tempo para os experimentos em branco e com amostra. 


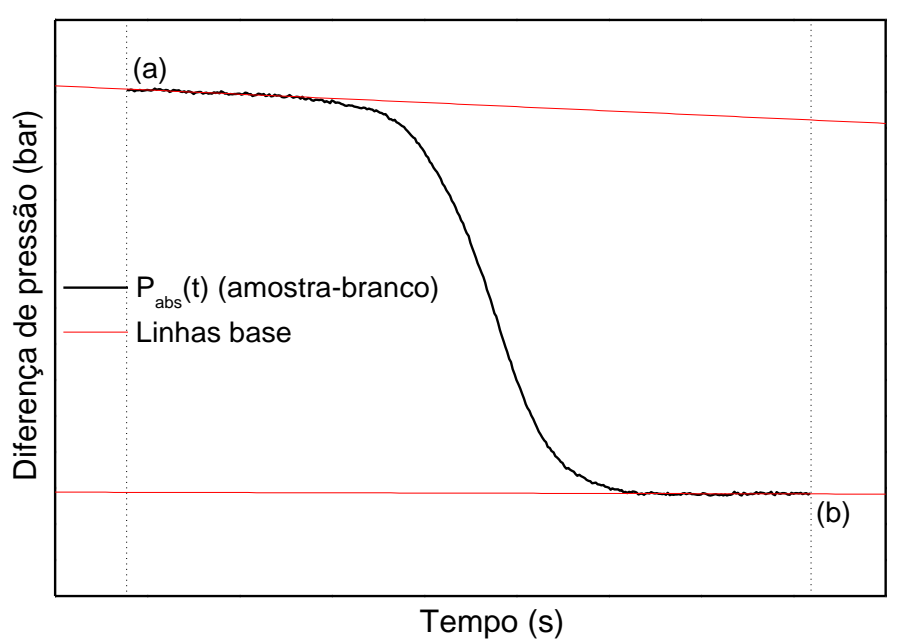

FIGURA 50 - Curva típica da diferença de pressão do equipamento em função do tempo para a absorção de hidrogênio no intervalo $a \leq t \leq b$.

Um ponto relevante destas análises é o limite de aplicação da EQUAÇÃO 13, que deve obedecer as seguintes hipóteses:

Hipótese 1 - Os experimentos em branco e com amostra são realizados em condições idênticas de temperatura e volume de trabalho do equipamento. Esta hipótese garante que não ocorram variações significativas na diferença de pressão do equipamento devido a diferentes condições de temperatura e volume de trabalho quando da realização dos experimentos em branco e o com amostra.

Hipótese 2 - A temperatura e volume constantes, para que seja mantida a relação de proporcionalidade entre a taxa e o fluxo de entrada ou de saída de hidrogênio, assumida na EQUAÇÃO 13, a curva $P(n)$ (ver FIGURA 51) deve se manter linear dentro do limite de operação do equipamento (entre 0,2 e 21bar). Contudo, como é sabido da teoria de gases reais, existe um limite para esta relação de linearidade. No entanto, como mostra a FIGURA 51, as medidas realizadas não apresentaram desvios significativos, pelo menos dentro das incertezas apresentadas, para o intervalo de pressão investigado, o que justifica a aplicação da EQUAÇÃO 13. 


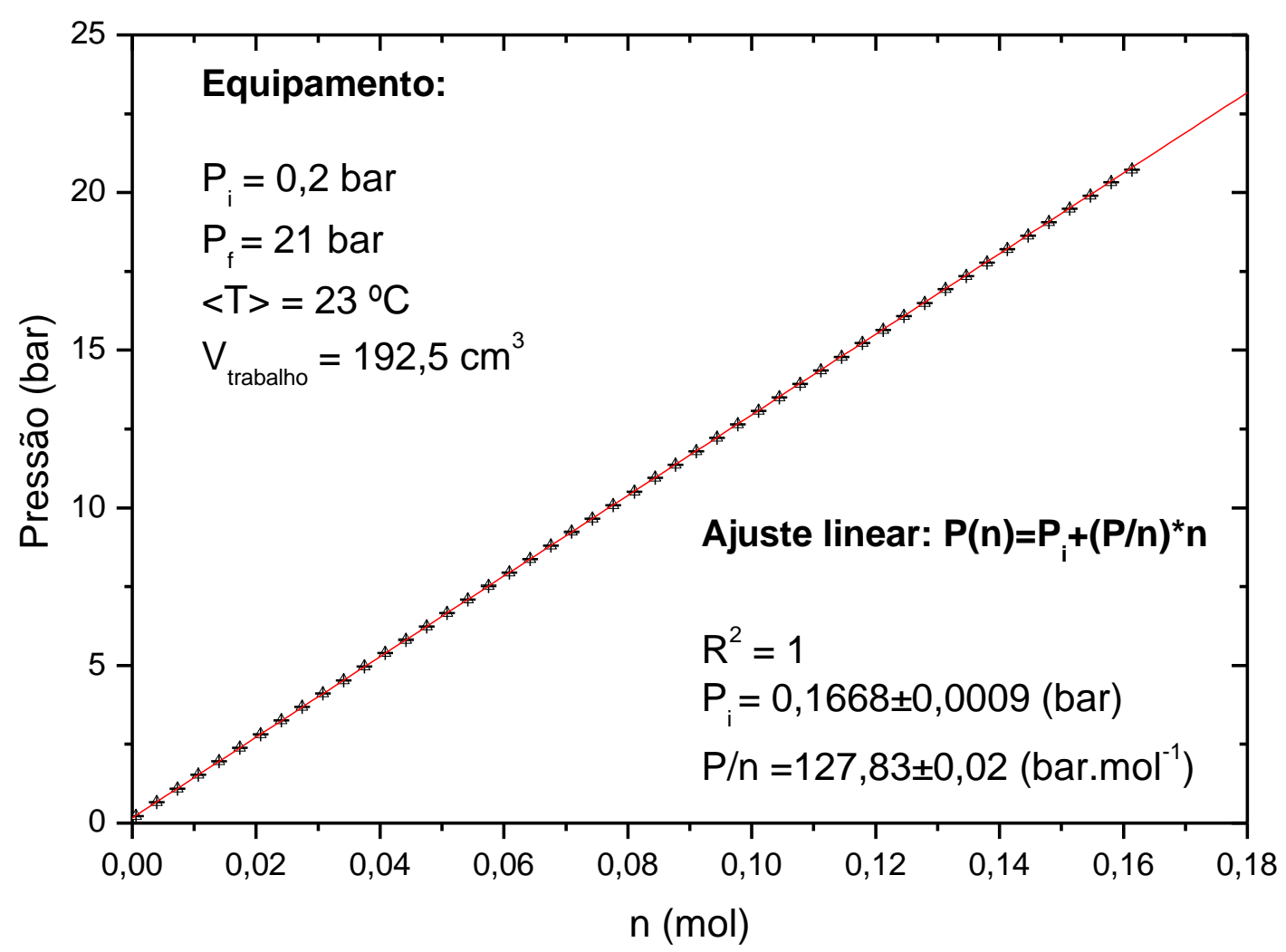

FIGURA 51 - Curva da pressão em função do número de mols de hidrogênio introduzidos no volume de trabalho do equipamento Sievert.

Com relação à precisão dos resultados fornecidos pelo equipamento, foram realizados inicialmente uma série de experimentos com pó de $\mathrm{Ti}$ da AEE $^{\circledR}$ (99,7\% de pureza, -325 mesh). A massa dos pós de Ti utilizada nos experimentos foi de aproximadamente $0,5 \mathrm{~g} \quad(0,5134$ e $0,5019 \mathrm{~g}$, respectivamente para Ti-01 e Ti-02), medida com o auxilio de uma balança digital analítica (Ohaus Adventure ${ }^{\circledR} ; \sigma=0,0001 \mathrm{~g}$ ). As amostras já pesadas foram aquecidas sob vácuo dinâmico até a temperatura desejada $\left(500^{\circ} \mathrm{C}\right)$. Após atingir a temperatura de aproximadamente $460^{\circ} \mathrm{C}$ (a temperatura de $500^{\circ} \mathrm{C}$ só foi atingida após alguns minutos do início do processo de hidretação) a retorta foi conectada ao sistema Sievert para as rotinas de pressurização na faixa de 0,2 a 1,4bar, onde se utilizou um fluxo nominal contínuo de entrada de hidrogênio $\phi_{\text {ent }}=9 \mathrm{~cm}^{3} / \mathrm{min}$. $\left(0,15 \mathrm{~cm}^{3} / \mathrm{s}\right)$ de pureza $99,999 \%$.

Após as rotinas de pressurização, a partir dos dados fornecidos pelo equipamento, foram construídas as curvas apresentadas na FIGURA 52, e cujos principais resultados estão sintetizados na TABELA 15. Nestas curvas, observa-se um comportamento decrescente da pressão em função do tempo, 
atribuído à absorção de hidrogênio pela amostra e subsequente formação da fase hidreto (ver TABELA 15). Esta reação é tipicamente exotérmica, o que explica o aumento local observado na temperatura das amostras nos trechos de absorção ( $30^{\circ} \mathrm{C}$ em relação à temperatura média). Ainda na TABELA 15 , com relação aos valores de $\mathrm{H}: \mathrm{M}$ e $\mathrm{H}$, relacionados à capacidade de armazenamento de hidrogênio, observa-se que em média estes correspondem a aproximadamente $89 \%$ do valor esperado para o hidreto teórico $\gamma \mathrm{TiH}_{2}$. Segundo a literatura, nas condições de pressão e temperatura investigadas $\left(\sim 1,4\right.$ bar; $\left.\sim 500^{\circ} \mathrm{C}\right)$, este valor deveria corresponder a aproximadamente $91 \%$ do valor teórico [86], um desvio relativo de aproximadamente $2 \%$, o que enseja uma boa aproximação, levando-se em conta ainda uma possível oxidação das amostras durante os experimentos. Diante do apresentado, concluiu-se que o equipamento Sievert poderia fornecer resultados relativamente precisos nos experimentos que se sucederiam. 
TABELA 15 - Propriedades de absorção de hidrogênio das amostras de Ti puro.

\begin{tabular}{|c|c|c|c|c|c|c|}
\hline Amostra & Fase & $\begin{array}{c}<\phi_{\mathrm{abs}}> \pm \sigma<\phi_{\mathrm{abs}}> \\
\left(\mathrm{cm}^{3} / \mathrm{min} . \mathrm{g}\right)\end{array}$ & $\mathrm{H}: \mathrm{M} \pm 0,023$ & $\begin{array}{c}\mathrm{H} \pm 0,05 \\
\text { (\% em massa) }\end{array}$ & $<\mathrm{T}>/ \mathrm{T}_{\text {máx. }}\left({ }^{\circ} \mathrm{C}\right)$ & $\begin{array}{c}\mathrm{TiH}_{2} \pm 0,6 \\
\text { (\% de formação) }\end{array}$ \\
\hline \multirow{4}{*}{ Ti-01 } & $\alpha$ & $0,3 \pm 0,4$ & 0,027 & 0,06 & \multirow{4}{*}{$485,2 / 516,8$} & \multirow{4}{*}{89,0} \\
\hline & $\alpha+\gamma$ & $374 \pm 10$ & 1,729 & 3,51 & & \\
\hline & & & & & & \\
\hline & $\gamma$ & $0,3 \pm 0,5$ & 0,025 & 0,05 & & \\
\hline \multirow[b]{3}{*}{ Ti-02 } & $\alpha$ & $0,2 \pm 0,4$ & 0,024 & 0,05 & \multirow[b]{3}{*}{$498 / 527,5$} & \multirow[b]{3}{*}{89,4} \\
\hline & $\alpha+\gamma$ & $354 \pm 10$ & 1,715 & 3,49 & & \\
\hline & & & & & & \\
\hline
\end{tabular}



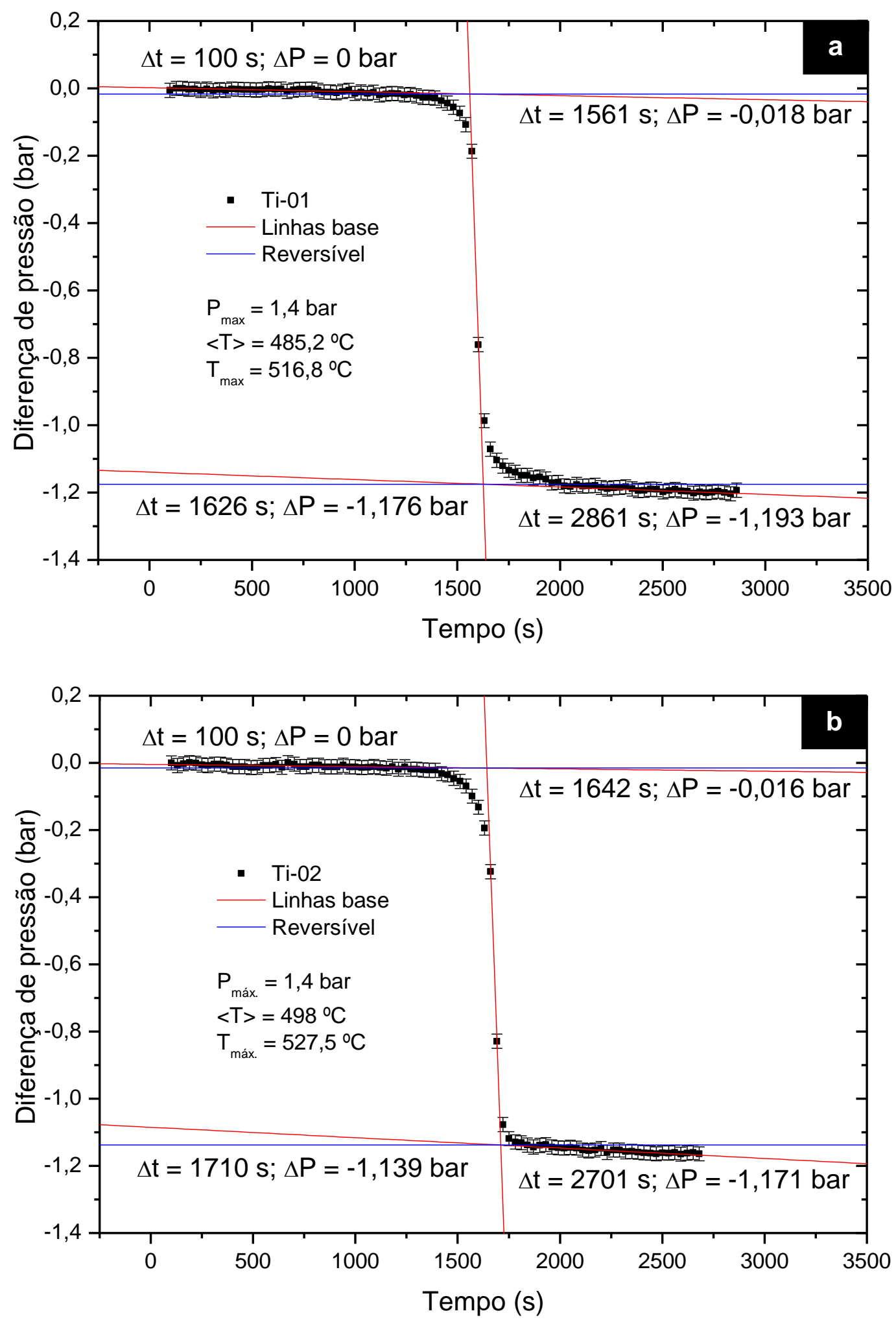

FIGURA 52 - Diferença de pressão do equipamento em função do tempo para a absorção de hidrogênio das amostras de Ti puro: (a) Ti-01; (b) Ti-02. 


\section{APÊNDICE C - Refinamentos pelo método de Rietveld}

Na FIGURA 53 a FIGURA 62 são apresentados os ajustes dos padrões de DRX obtidos por meio da aplicação do método de Rietveld de refinamento, utilizando o software Diffrac ${ }^{\text {Plus }}$ Topas 4.2 da Brucker $^{\circledR}$. A qualidade desses ajustes foi avaliada pela razão entre o resíduo padrão ponderado $R_{w p}$ e o seu valor esperado $\mathrm{R}_{\exp }$ (ambos fornecidos pelo software), também conhecida como "Goodness of fit" $(S)$ [76]. Nas amostras investigadas, os valores de $S$ ficaram, de forma geral, entre 1,07 e 1,56. Somente em alguns casos, de amostras moídas por 5 horas (FIGURA 57 e FIGURA 61), foram observados valores de $S$ superiores a 1,7.

Segundo Young (1995), valores de $S$ entre 1,0 e 1,3 podem ser considerados satisfatórios para os ajustes. Já valores de $S$ superiores a 1,7, por exemplo, são provavelmente um alerta para a adequação do modelo adotado. Por outro lado, valores de $S$ demasiadamente pequenos podem alertar que os erros estatísticos da medida superam em muito os erros do modelo, seja devido a uma baixa estatística ou a um alto nível de ruído de fundo [77]. Diante do exposto, os ajustes obtidos no presente trabalho foram considerados satisfatórios. 

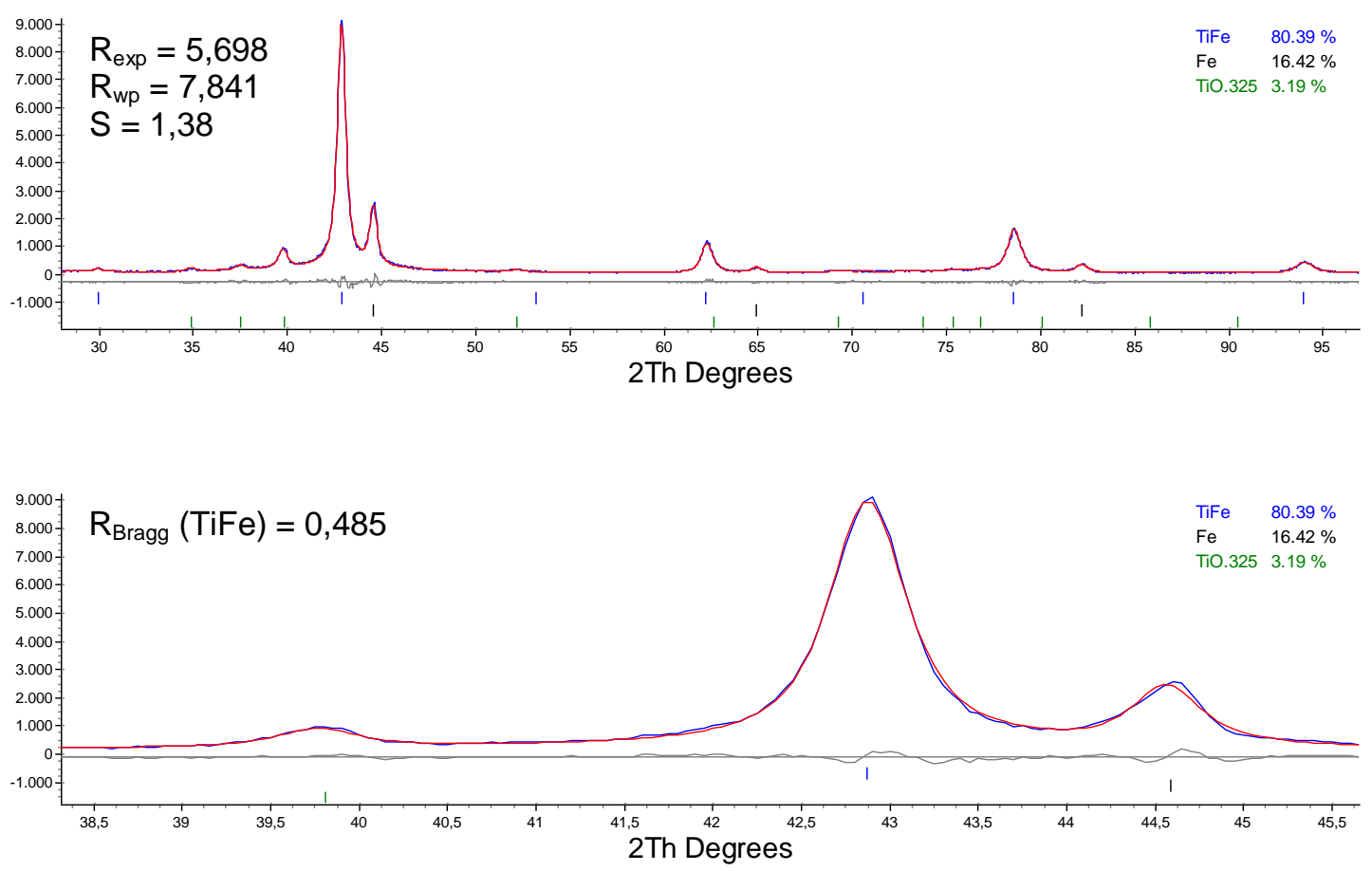

5 horas de moagem
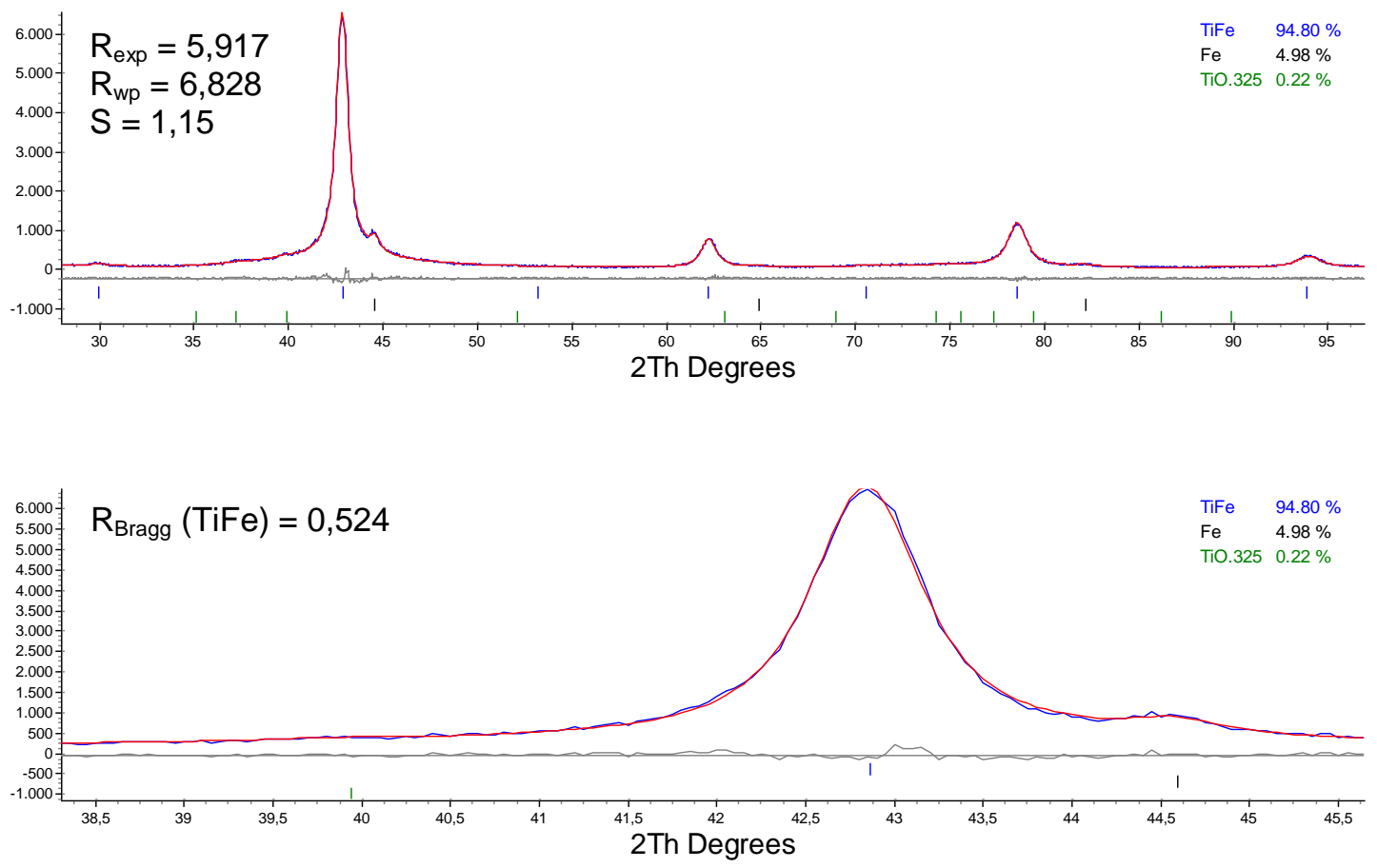

10 horas de moagem

FIGURA 53 - Ajuste dos padrões de difração de raios $X$ (DRX) das amostras moídas por 5 e 10 horas e reagidas a $600^{\circ} \mathrm{C}$ da composição 50:50. 

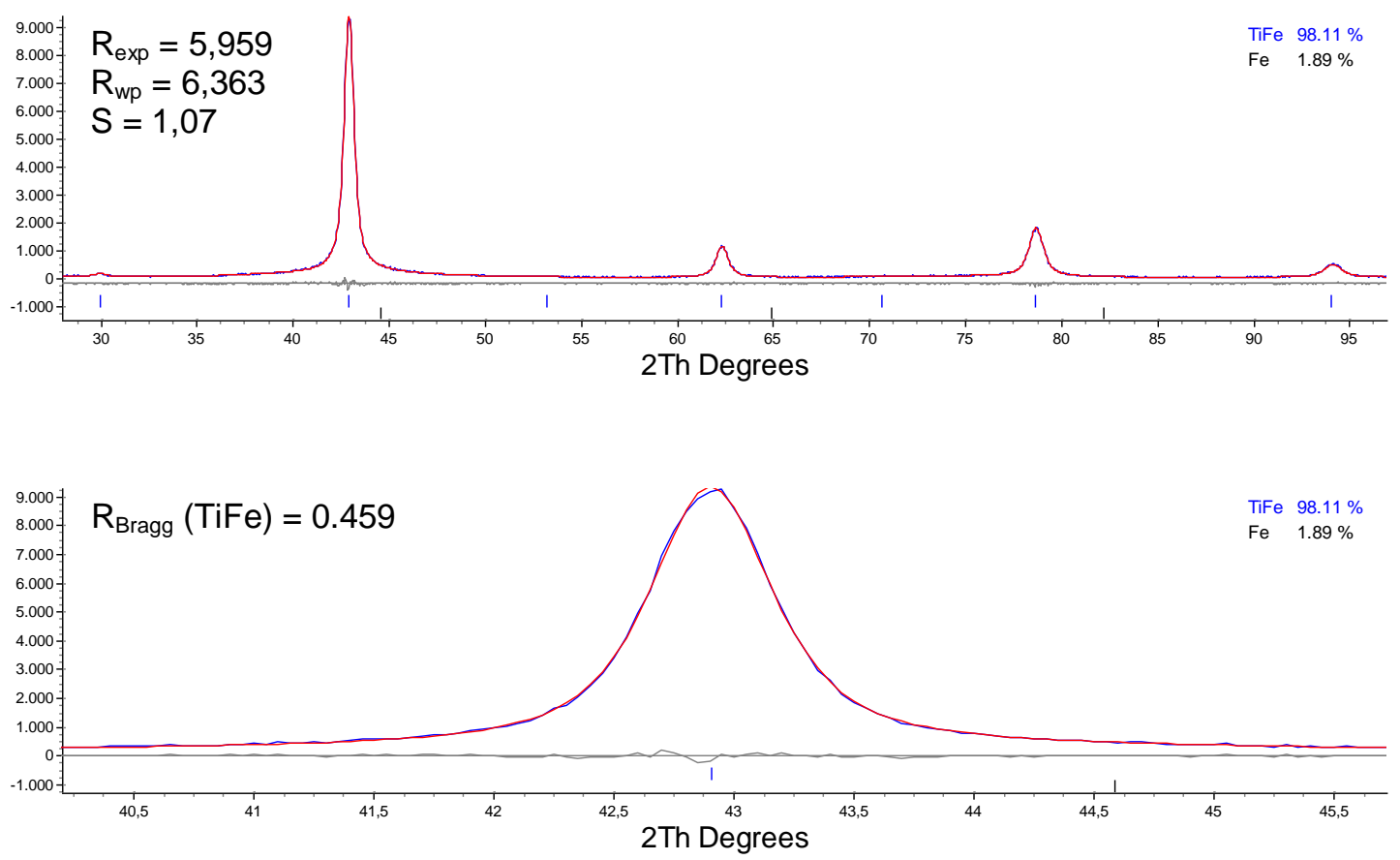

25 horas de moagem
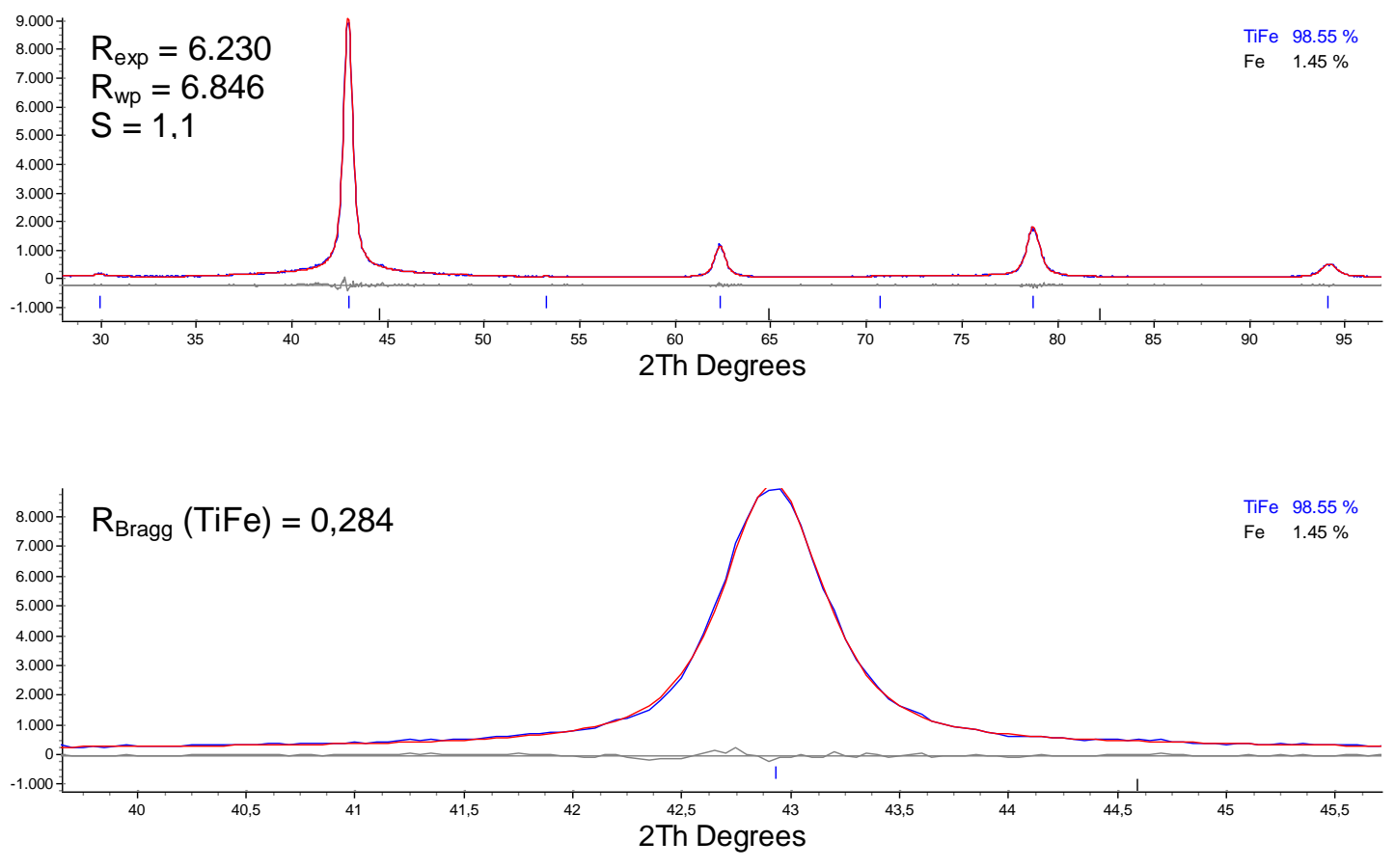

40 horas de moagem

FIGURA 54 - Ajuste dos padrões de difração de raios X (DRX) das amostras moídas por 25 e 40 horas e reagidas a 600ㄷ da composição 50:50. 

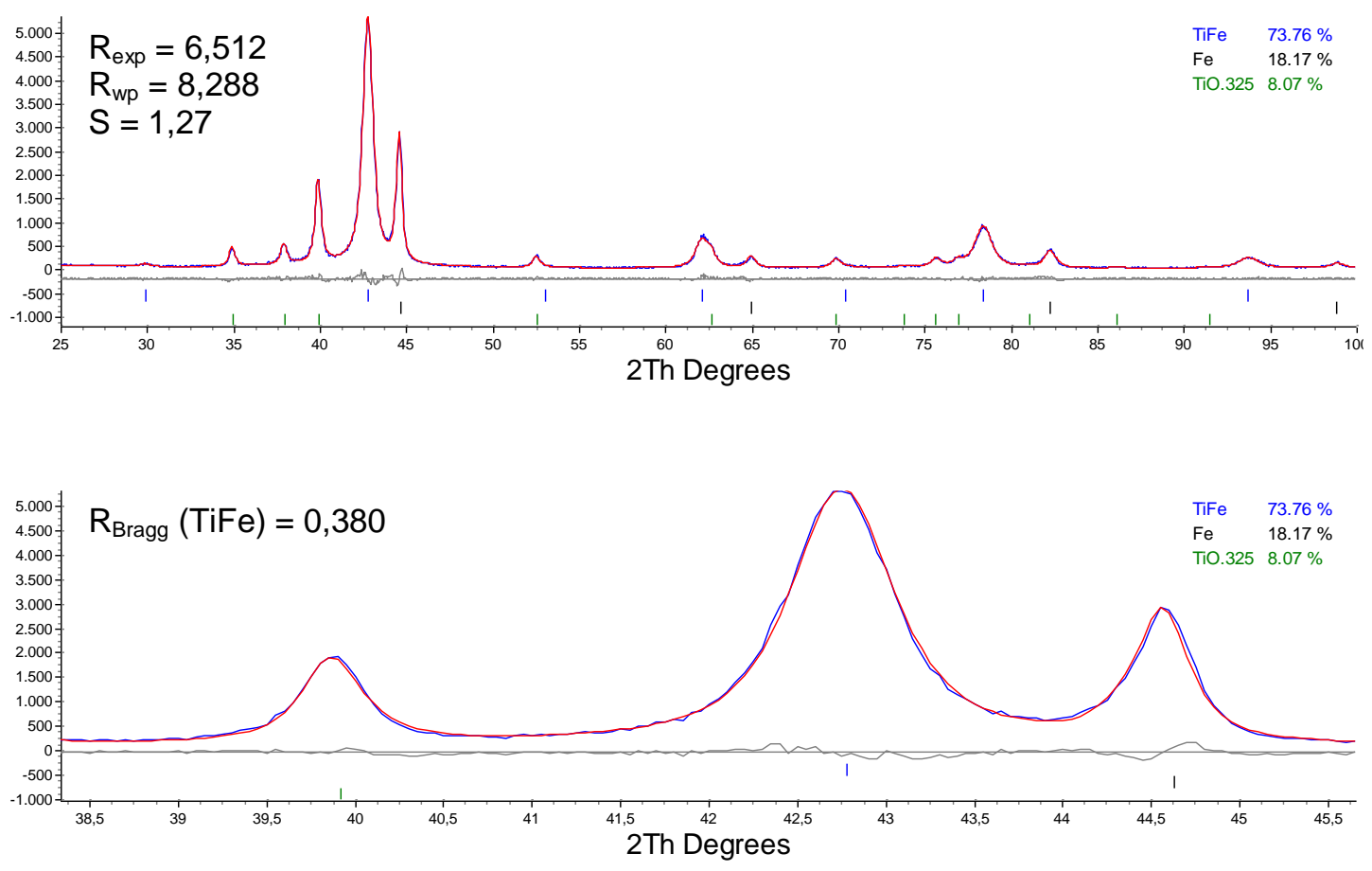

5 horas de moagem
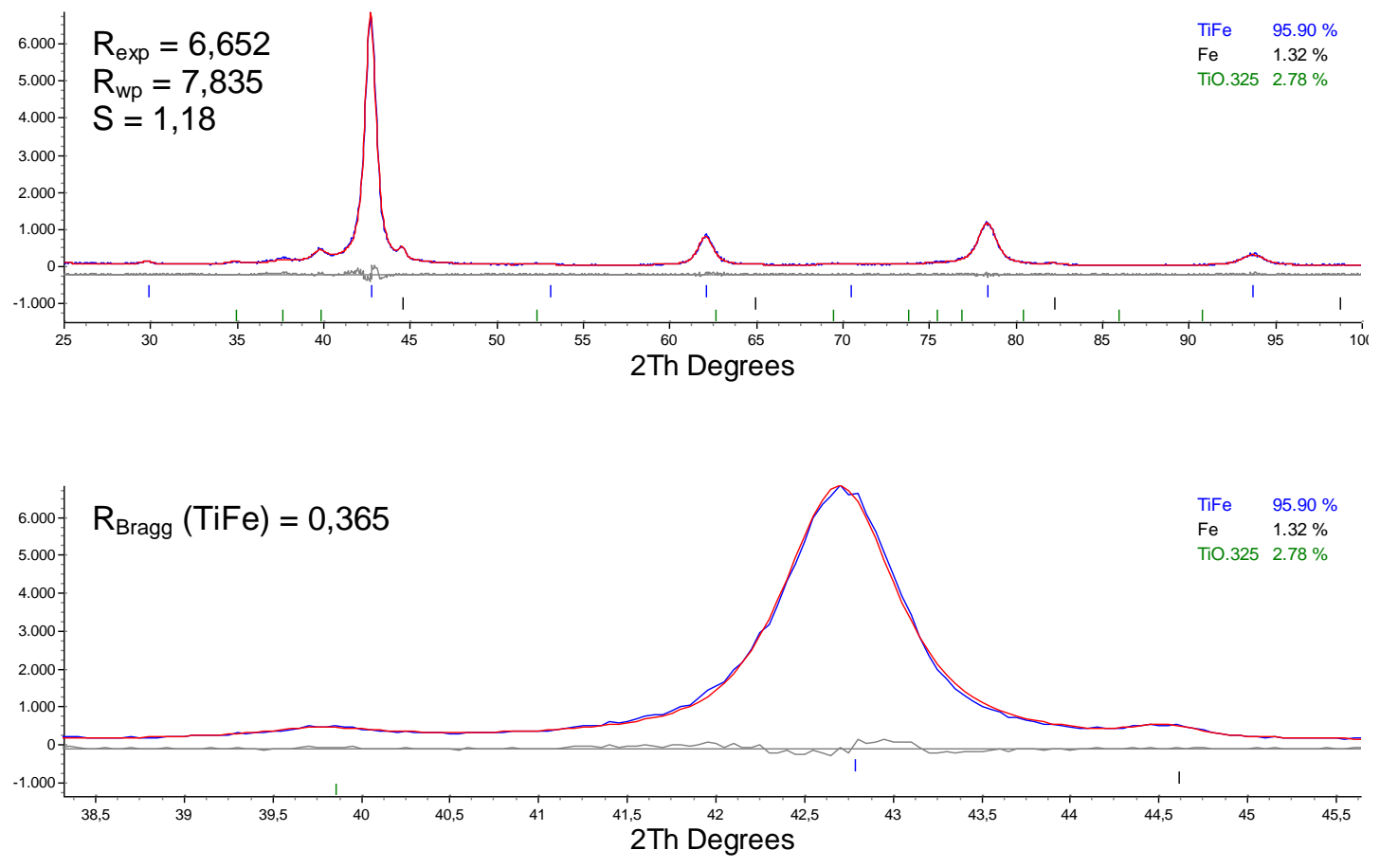

10 horas de moagem

FIGURA 55 - Ajuste dos padrões de difração de raios $X$ (DRX) das amostras moídas por 5 e 10 horas e reagidas a 600 da composição 56:44. 

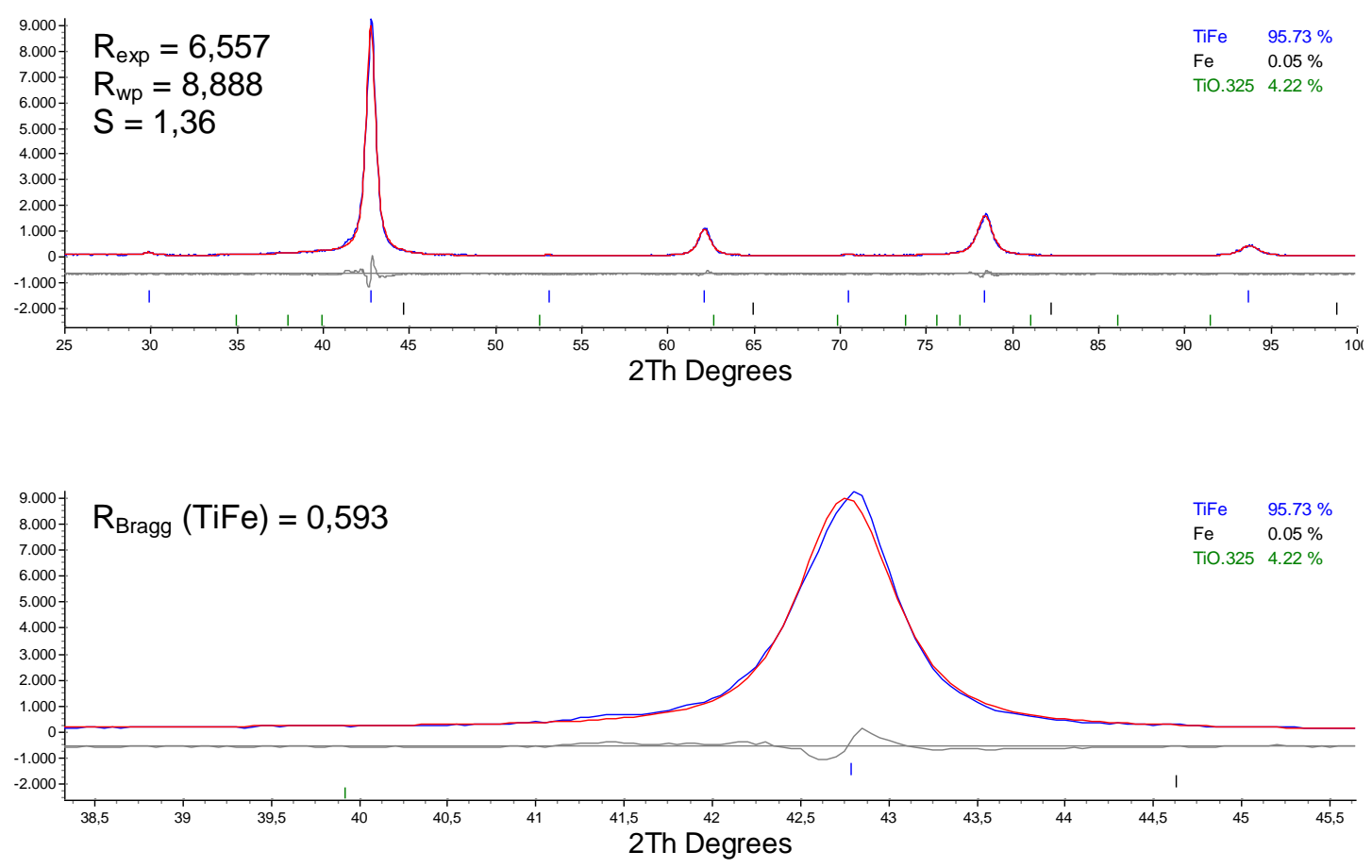

25 horas de moagem
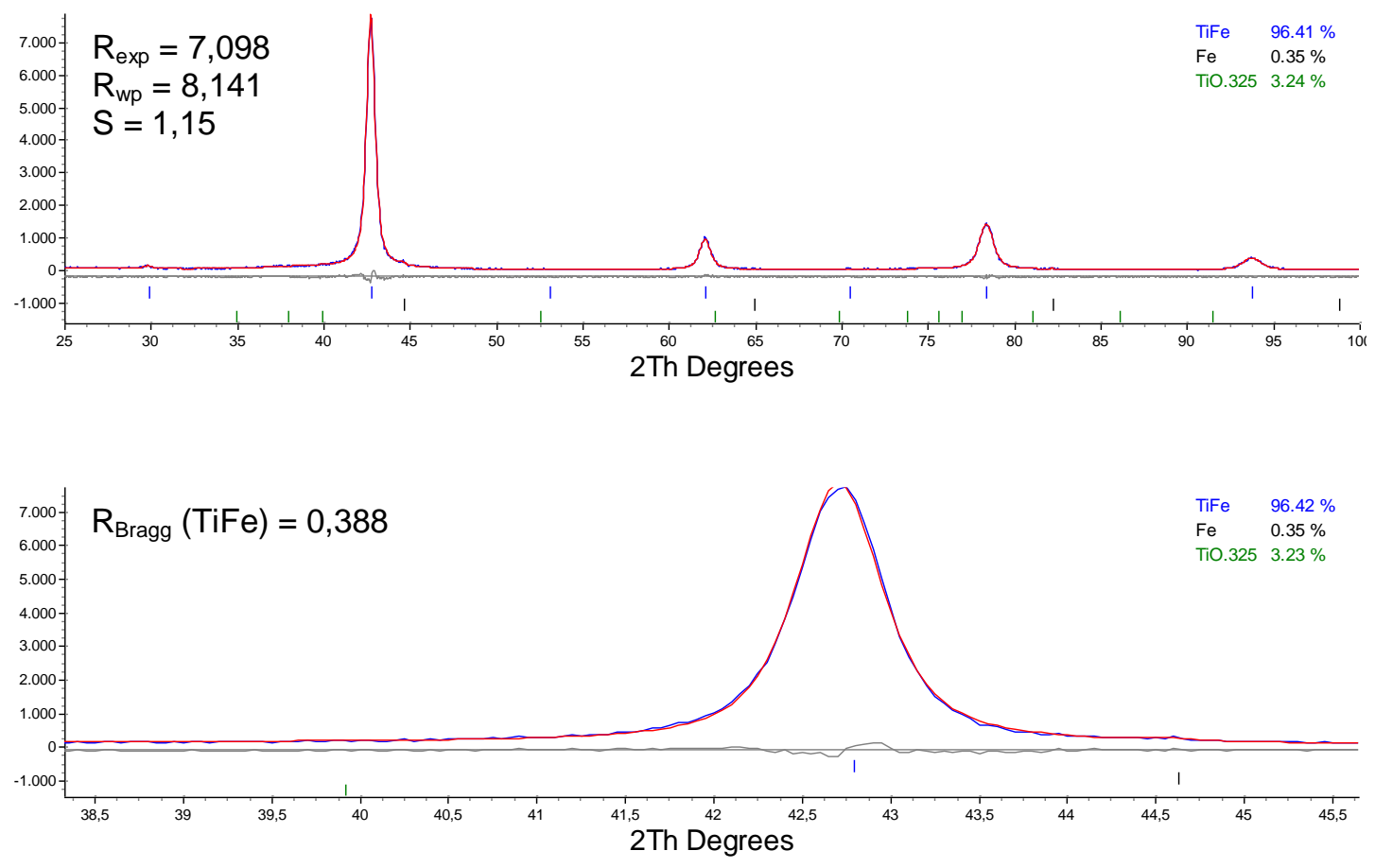

40 horas de moagem

FIGURA 56 - Ajuste dos padrões de difração de raios $\mathrm{X}$ (DRX) das amostras moídas por 25 e 40 horas e reagidas a $600^{\circ} \mathrm{C}$ da composição 56:44. 

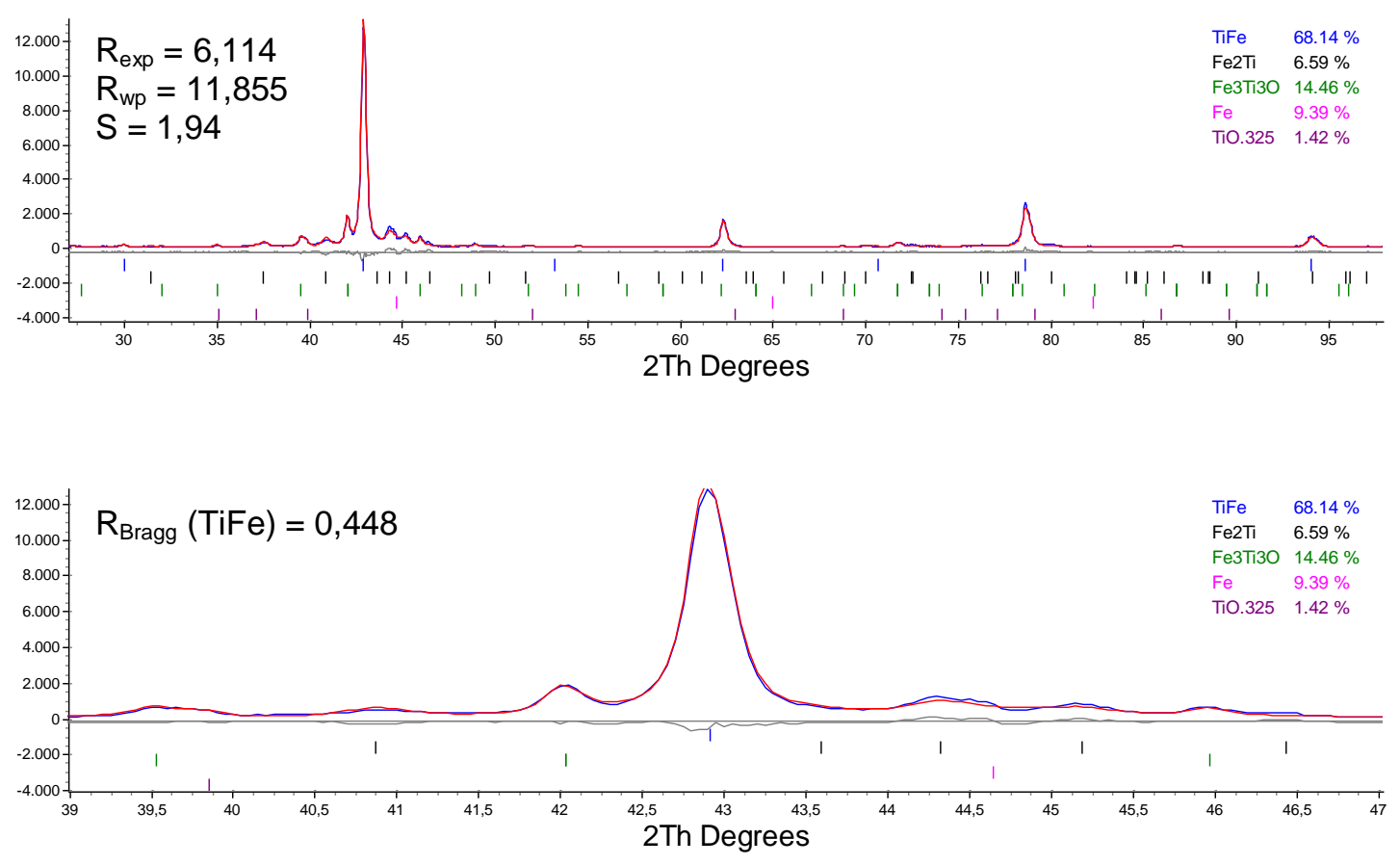

5 horas de moagem
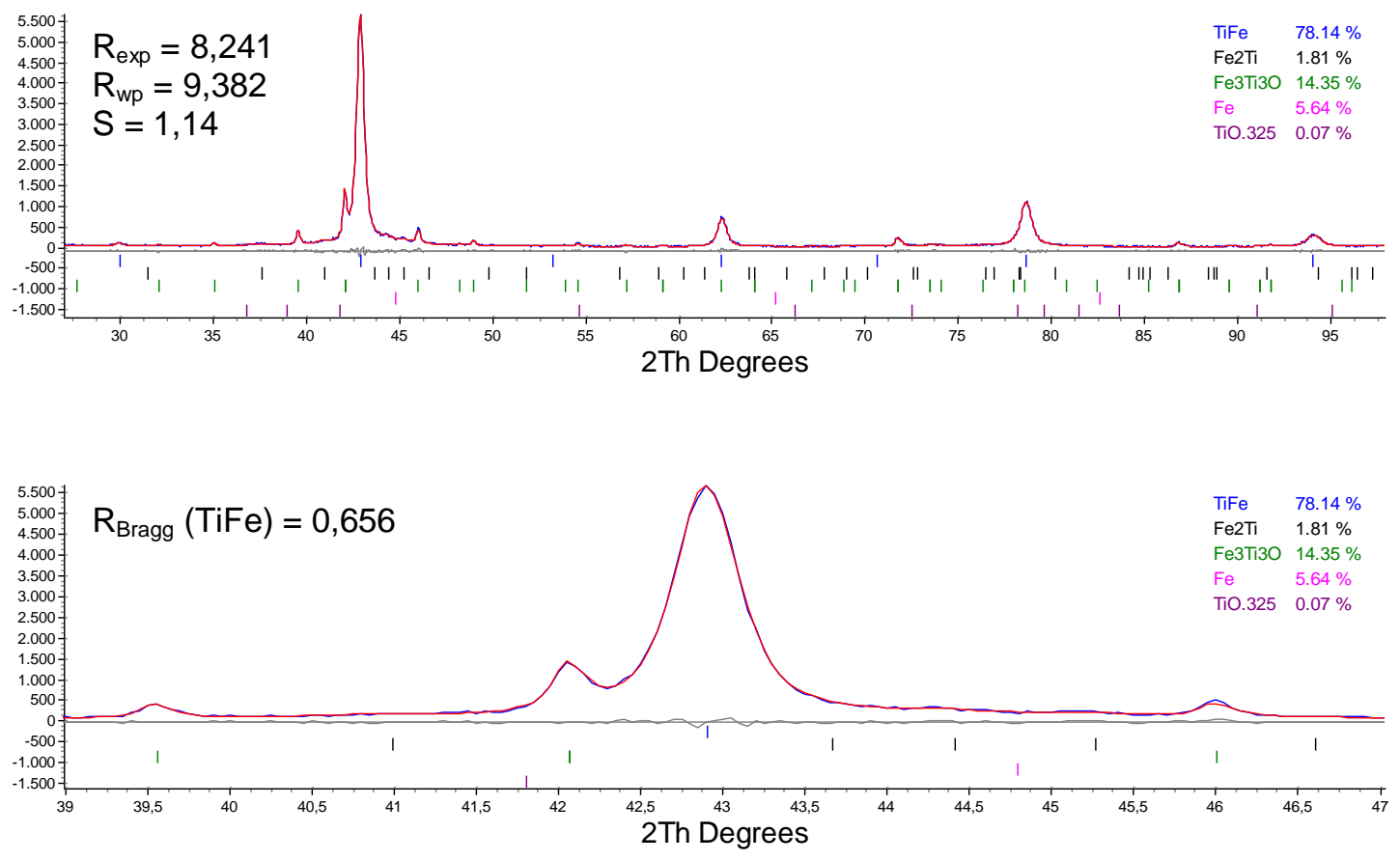

10 horas de moagem

FIGURA 57 - Ajuste dos padrões de difração de raios $\mathrm{X}$ (DRX) das amostras moídas por 5 e 10 horas e reagidas a 800C da composição 50:50. 

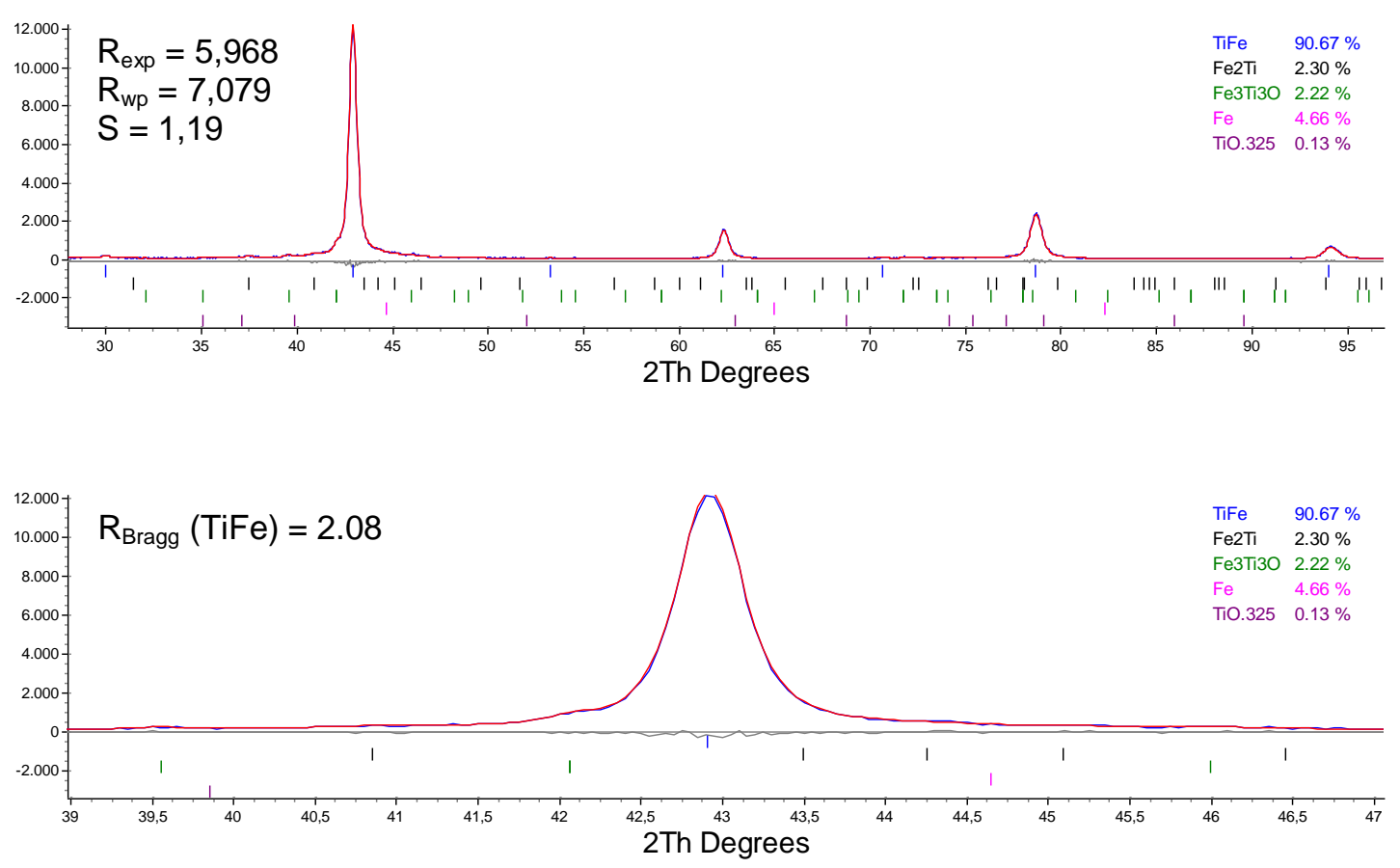

25 horas de moagem
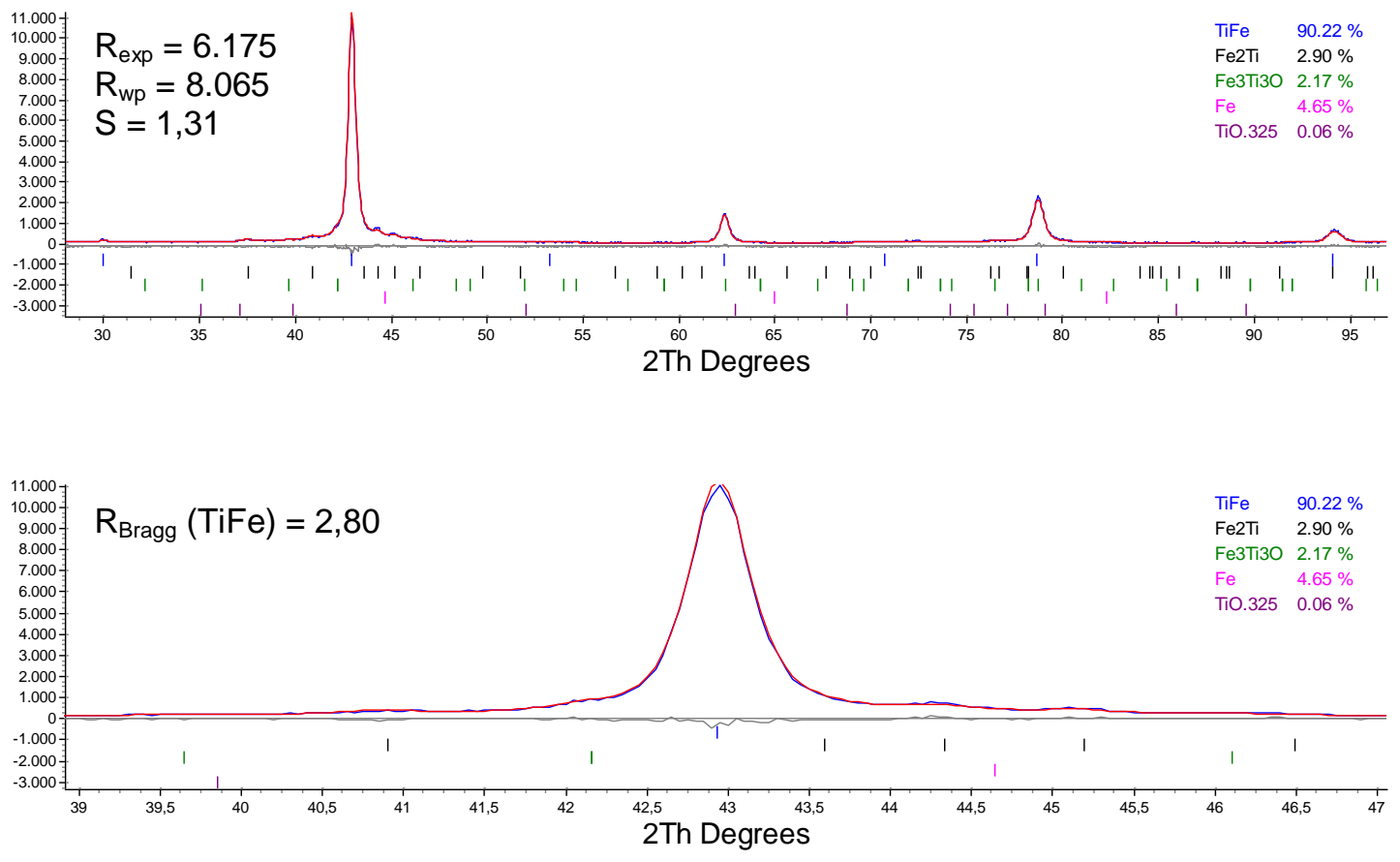

40 horas de moagem

FIGURA 58 - Ajuste dos padrões de difração de raios $\mathrm{X}$ (DRX) das amostras moídas por 25 e 40 horas e reagidas a 800 da composição 50:50. 

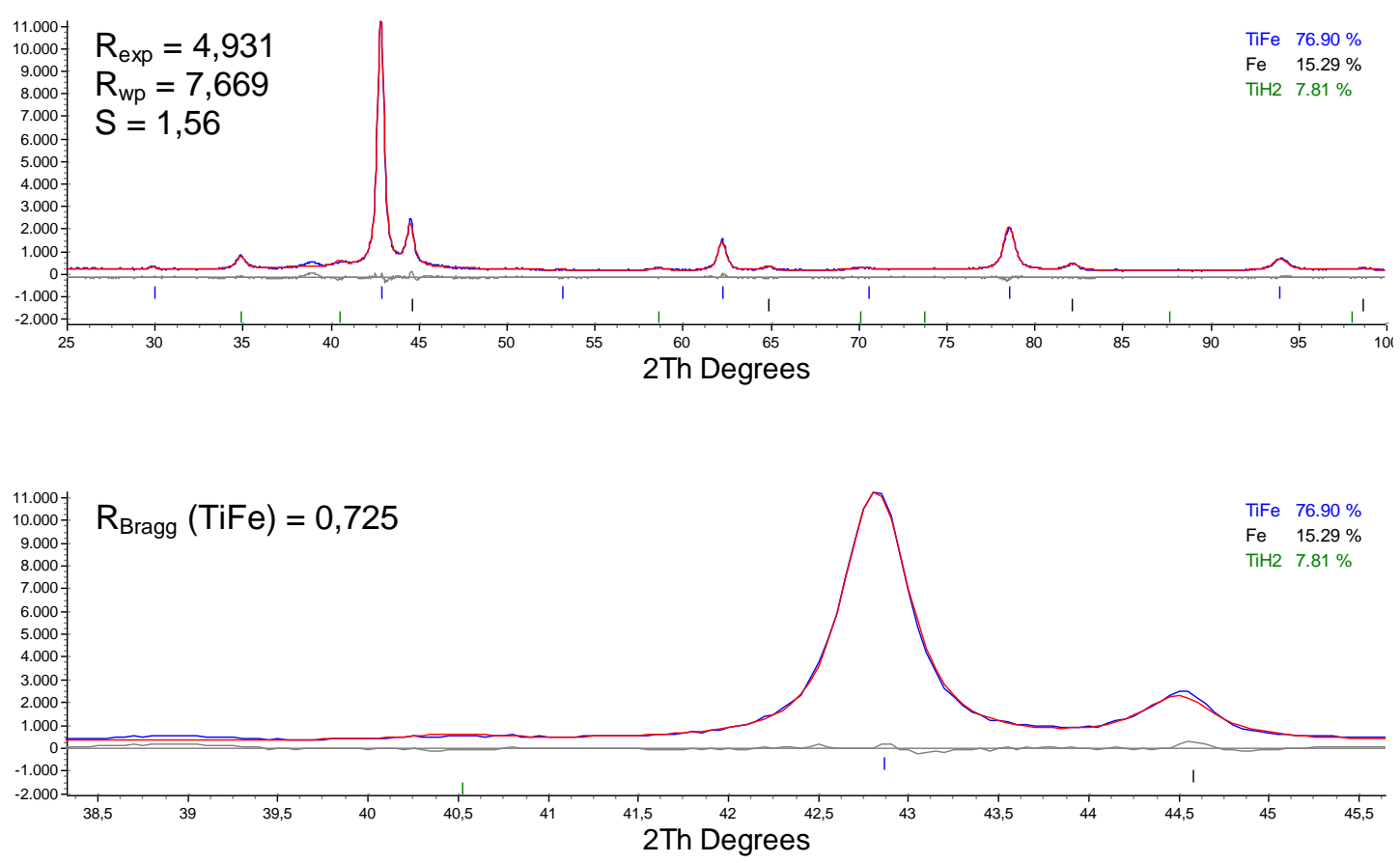

5 horas de moagem
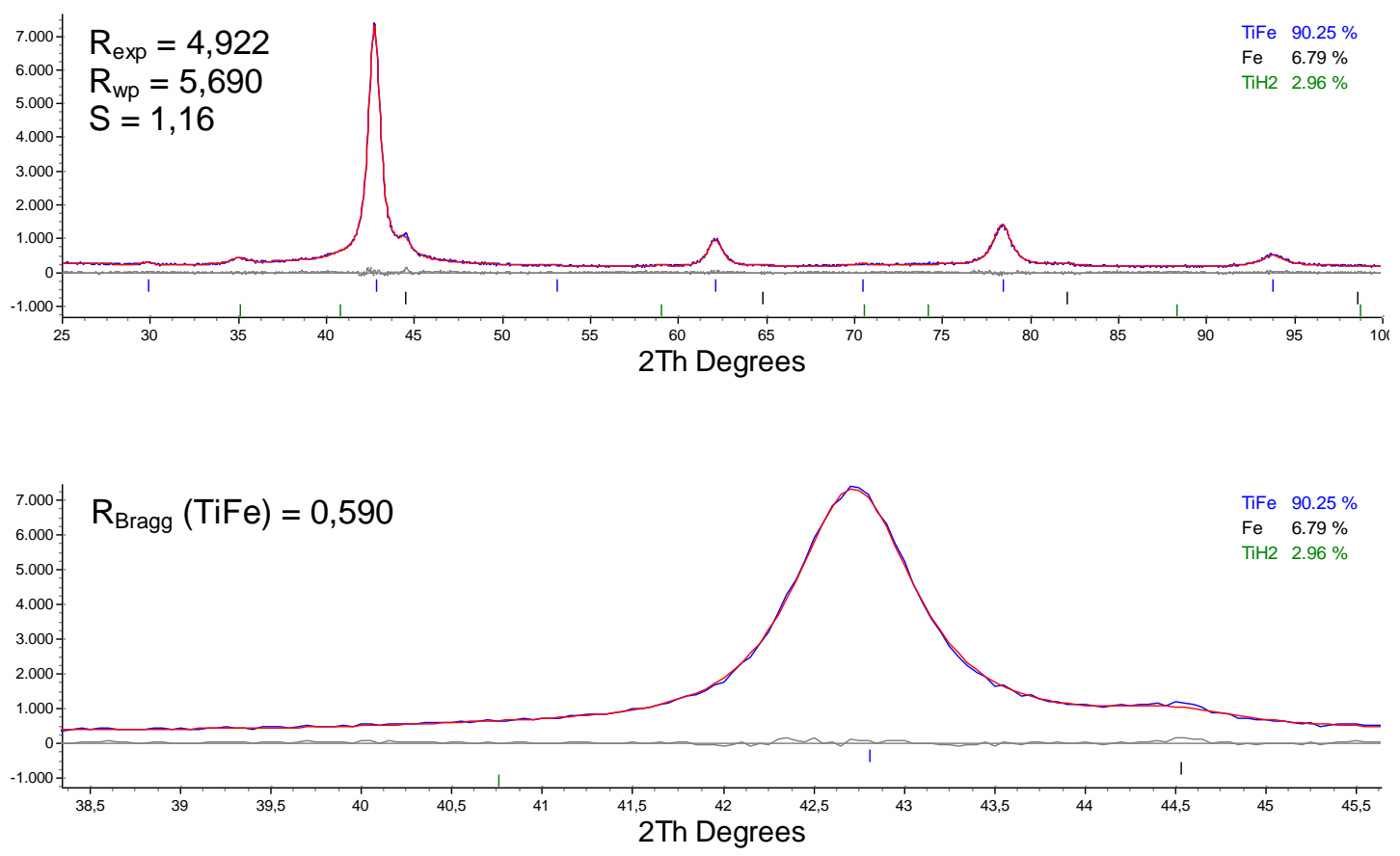

10 horas de moagem

FIGURA 59 - Ajuste dos padrões de difração de raios X (DRX) das amostras moídas por 5 e 10 horas e reagidas a $600^{\circ} \mathrm{C}$ da composição 50:50 após o ciclo de hidretação. 

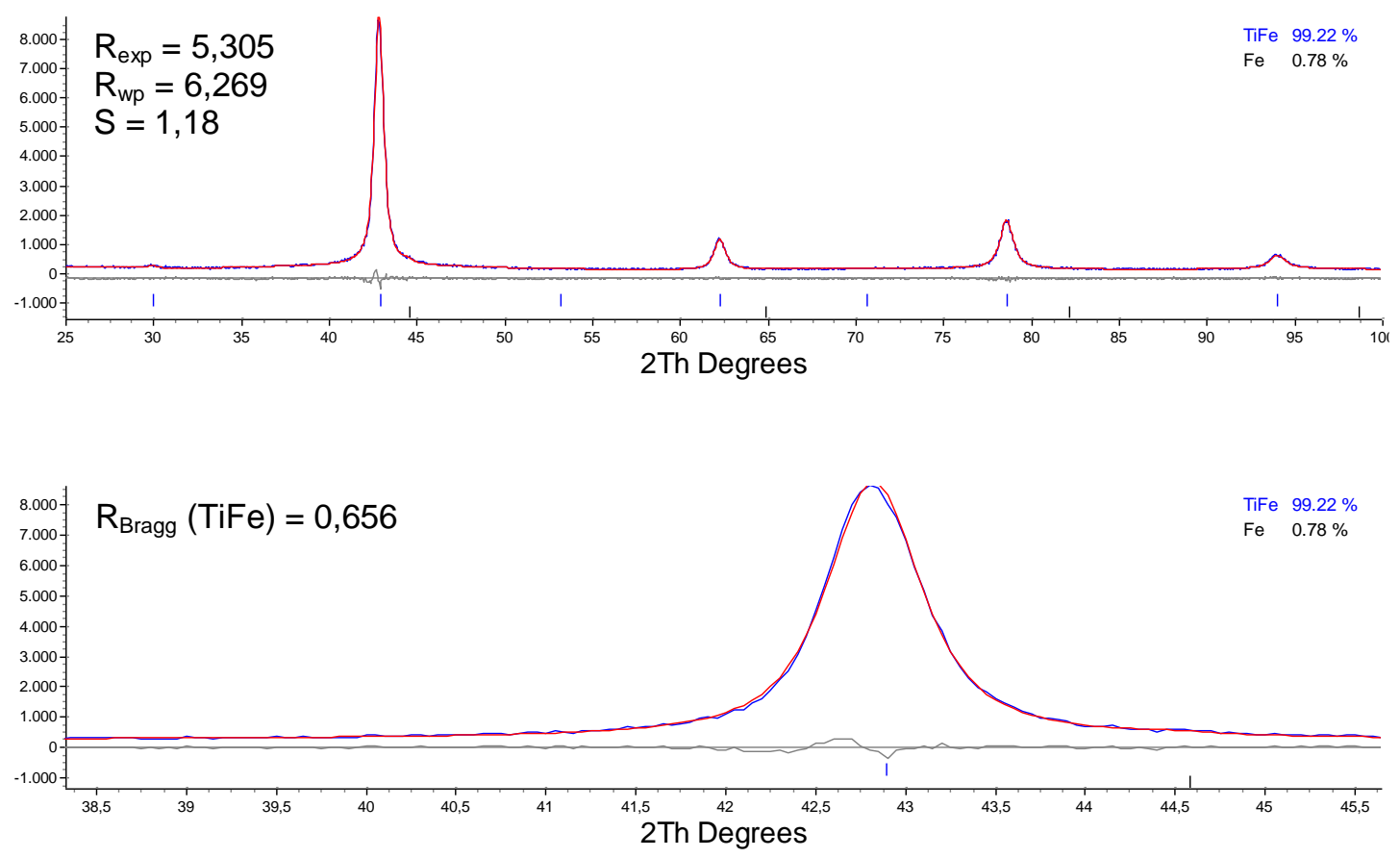

25 horas de moagem
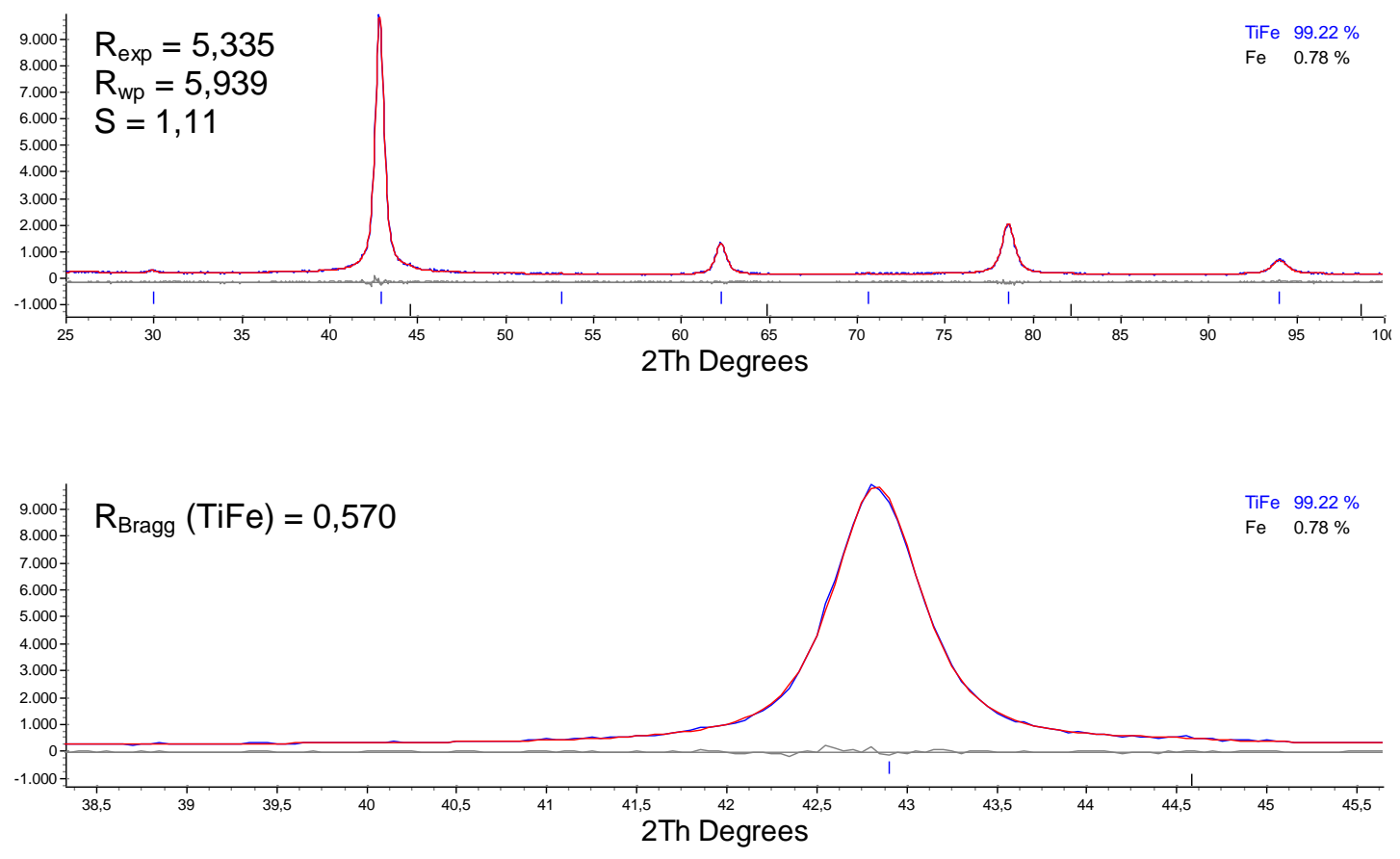

40 horas de moagem

FIGURA 60 - Ajuste dos padrões de difração de raios $X$ (DRX) das amostras moídas por 25 e 40 horas e reagidas a $600^{\circ} \mathrm{C}$ da composição 50:50 após 0 ciclo de hidretação. 

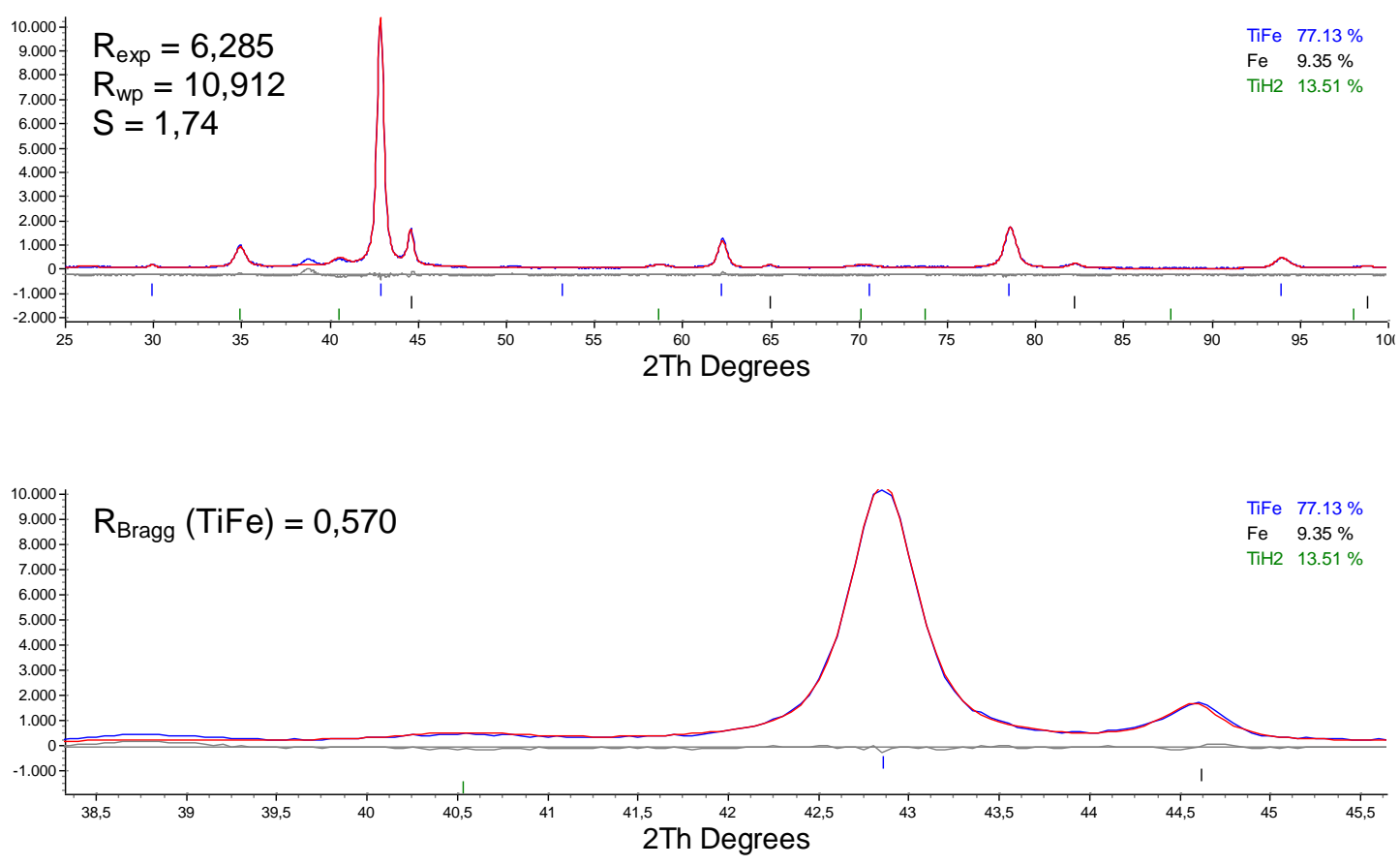

5 horas de moagem
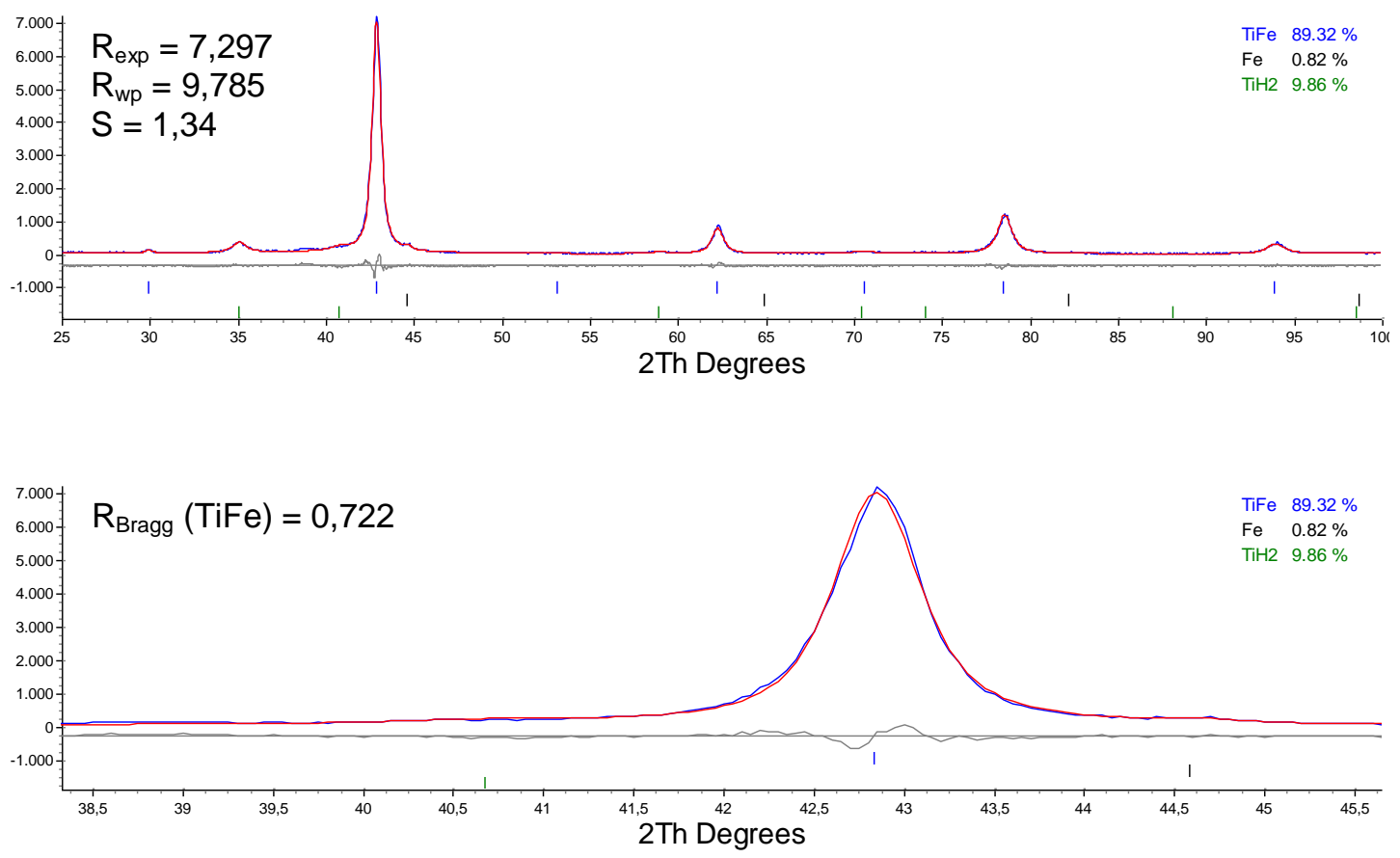

10 horas de moagem

FIGURA 61 - Ajuste dos padrões de difração de raios $X$ (DRX) das amostras moídas por 5 e 10 horas e reagidas a $600^{\circ} \mathrm{C}$ da composição $56: 44$ após o ciclo de hidretação. 

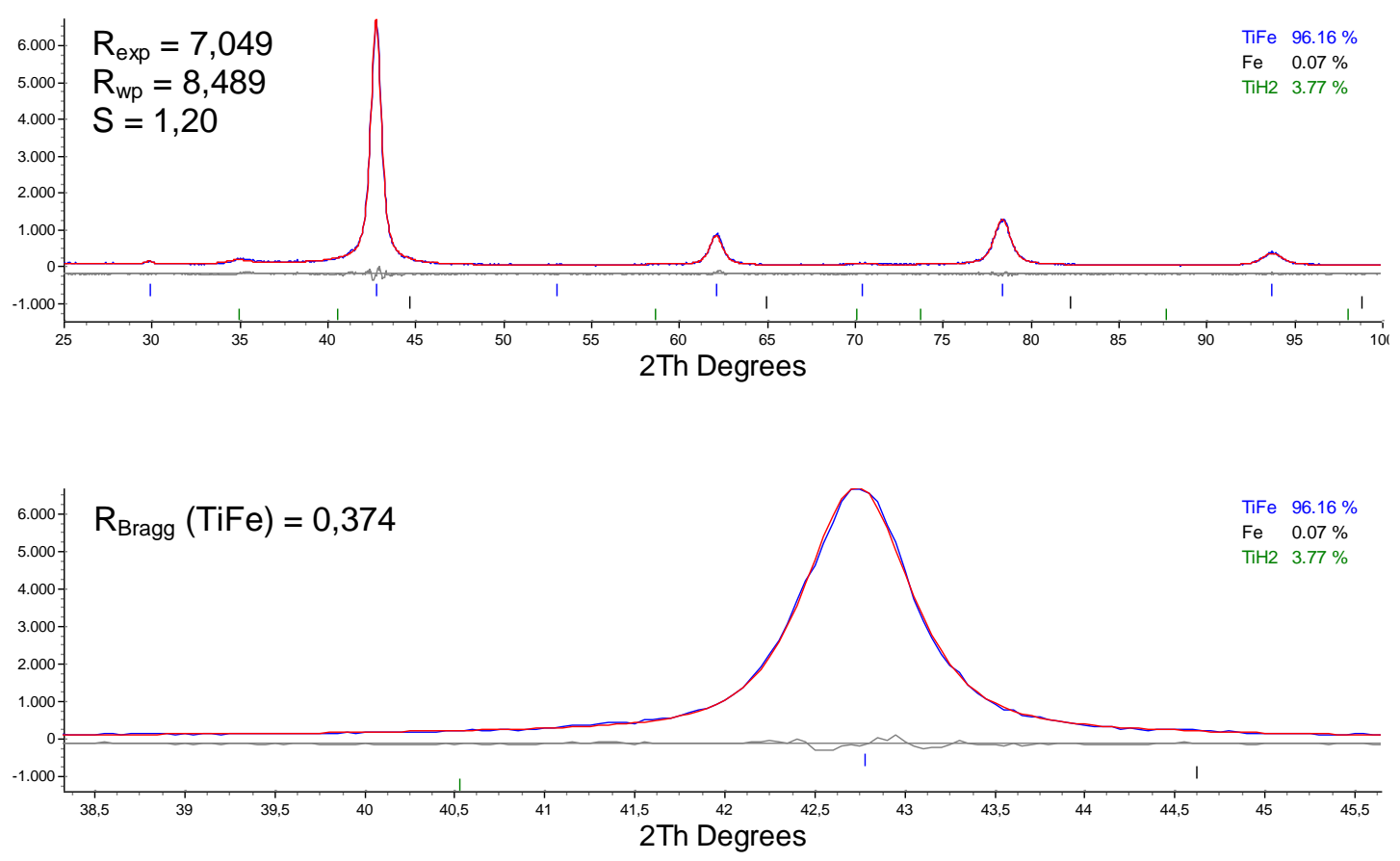

25 horas de moagem
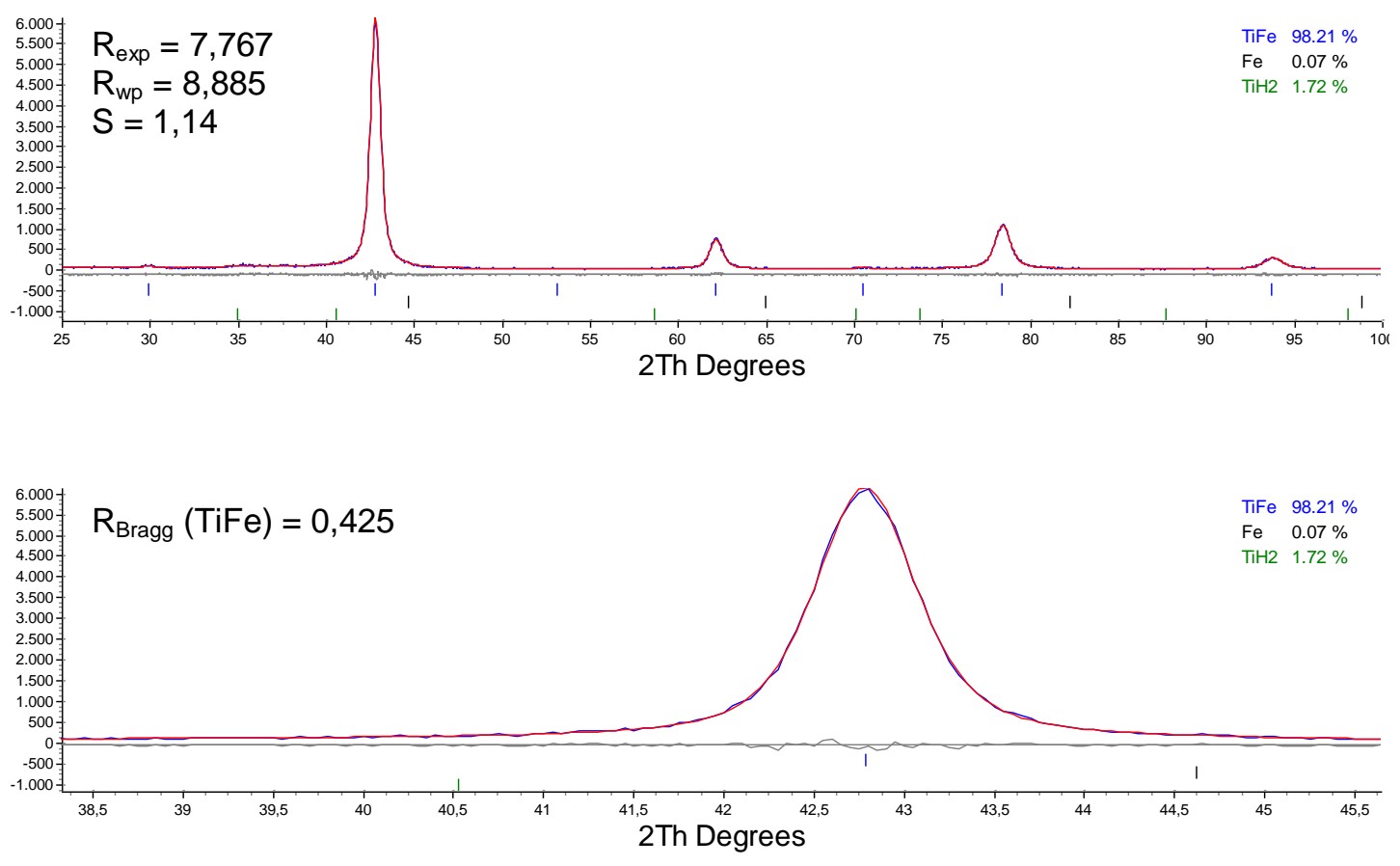

40 horas de moagem

FIGURA 62 - Ajuste dos padrões de difração de raios X (DRX) das amostras moídas por 25 e 40 horas e reagidas a $600^{\circ} \mathrm{C}$ da composição $56: 44$ após 0 ciclo de hidretação. 